\title{
AN UNBROKEN CONNECTION? NEW ZEALAND FAMILIES, DUTY, AND THE FIRST WORLD WAR
}

\author{
BY
}

RACHEL PATRICK

A thesis submitted to

Victoria University of Wellington

in fulfilment of the requirements for the degree of

Doctor of Philosophy in History

Victoria University of Wellington

2014. 
In loving memory of my father Ross Alexander Patrick, 6 May 1946 - 3 December 2013 


\section{ABSTRACT}

This thesis explores the topic of families during the First World War through a single New Zealand family and its social networks. The family at the core of the thesis, the Stewarts, were a well-to-do Dunedin family who moved in the most exclusive circles of colonial society. As members of the elite, and as prominent figures in the leadership of wartime patriotic organisations, they conceived of their wartime role as one of public benevolence and modelling patriotic virtue for others. Yet, like countless other families, their personal lives were shattered by the war. Drawing upon the extensive records left behind by the Stewart family, as well as associated archives, the thesis advances a number of larger arguments.

It is the overarching claim of this study that families - in their emotional, material and symbolic manifestations - formed an integral part of the war experience and provide a significant way of understanding this global event and its devastating human consequences. The Stewart family's extensive surviving archive of personal correspondence provides a window into the innermost emotions, beliefs and values of the family's individual members. Episodes in their wartime lives shape the wider thesis themes: the impact of family separations, grief and bereavement, religious faith, duty and patriotism, philanthropy, the lingering shadow of war disability - and the inflection of all of these by gender and class. Analysing the letters that the family exchanged with other correspondents demonstrates the embeddedness of family in larger networks of association, as well as identifying the aspects of their world view they shared with others in their predominantly middle- and upper-class circles. The records of patriotic organisations members of the family were associated with provide a means of examining how they translated their private beliefs into public influence.

The continual interplay between mobility and distance forms another of the study's substantive themes. The distance created by the geographical separation between battlefronts and homefronts was a defining feature of the war for families in far-flung dominions such as New Zealand. But distance could be overcome by mobility: through the flow of things, money and people. Such movements, the thesis argues, blurred the boundaries between home and front. Thus, the correspondence members of the Stewart 
family exchanged during the war enabled them to sustain intimate ties across distance and helped them to mediate their own particular experience of wartime bereavement. The informal personal and kinship networks sustained by the female members of the family formed an important constituent of wartime benevolence, providing a conduit for the flow of information, goods and financial aid across national boundaries. During the war, the leadership of women's patriotic organisations promoted an essentialised vision of feminine nature to justify their organisations' separate existence and to stake a claim for women's wider participation in the war effort. In doing so, they drew upon enlarged notions of kinship to argue that their female volunteers were uniquely qualified to bridge the distances of war, and to bring the emotional and practical comforts of home to frontline soldiers.

An alternative perspective to the Stewart family's story of war is provided in this thesis through counterpoints from casefiles of the Otago Soldiers' and Dependents' Welfare Committee, with which the Stewarts were involved. Here, the economic interdependence and mutual reliance of working-class families is laid bare in ways that differ markedly from the experience of the Stewarts, but which nevertheless underscores the centrality of the family as an institution for people of all social backgrounds. For some families the geographical separation imposed by the exigencies of war proved insurmountable. The very different kinds of families in this thesis illustrate that whether through their successes, or the sometimes dire consequences of their failures, families are nonetheless indispensable to understanding the First World War. 


\section{ACKNOWLEDGEMENTS}

My first thanks go to my supervisors, Kate Hunter and Jim McAloon, and to Geoff Troughton who generously agreed to step into that role to fill staff leave over 2012. Over the four years since I began this project, they have patiently followed the research on its various tangents and offered valuable advice and encouragement at critical junctures. The finished product has greatly benefited from their critical feedback. My knowledge of the wider historical scholarship on the First World War has been enhanced by the opportunity to teach Kate's 300-level course on the social and cultural history of the war over the past three years.

Various grants and scholarships have made this research possible. First, I would like to thank Victoria University for the award of a Vice-Chancellor's Strategic Research PhD Scholarship which covered course fees and a living stipend. A Victoria University $\mathrm{PhD}$ Submission scholarship provided vital financial assistance in the months leading up to the completion of this thesis. In addition, I would like to thank the Faculty of Humanities and Social Sciences for several grants to support travel for research. A Postgraduate Excellence Award funded by the Postgraduate Students' Association covered additional research costs and overseas conference attendance.

My next debt of gratitude is to the various librarians and archivists who have assisted me over the duration of my research. I would like to thank all the staff of the Hocken Library for their help, particularly Anna Blackman who granted access to the restricted First World War casefiles of the Otago Soldiers' and Dependents' Welfare Committee. Staff at Toitū Otago Settlers' Museum generously accommodated me during the museum's closure for refurbishment. Archives New Zealand staff fasttracked the digitisation of the personnel files of overseas volunteer workers at my request. My thanks also go to the descendants of the Stewart family, particularly RachelMary Perry, who assisted with family information as well as granting me access to the family papers held by the Macmillan Brown Library.

The Victoria University History Programme has provided supportive and collegial surroundings for research and my experience of postgraduate life has been 
greatly enhanced by the support and friendship of the various members of the "thesis group' over the years: Carl, Catherine, Charlotte, Coralie, David, Grace, James, Jo, Liz, Owen, Richard and Susann. Grace Millar, Rebecca Lenihan and Susann Liebich all read and offered feedback on chapters, and I am grateful for their input. Susann, with whom I shared an office for most of my $\mathrm{PhD}$ candidature, provided valuable advice on the research and writing process as well as friendship and welcome diversions from the thesis. In recent months, it has been a pleasure to share the first chicken-theme decorated office I have ever encountered with Janine Cook and Ambalika Guha. Finally I would like to thank my friends and family for their support over what has been a difficult year for our family. Greg Martin has sustained me in so many ways over this final stretch of completing my thesis, as well as single-handledly keeping the chaos at bay at home. For your patience, love and support, thank you. This thesis is dedicated to my father, who did not live to see it completed, but who would have been proud. 


\section{CONTENTS}

$\begin{array}{lll}\text { Abstract } & \text { V }\end{array}$

Acknowledgements vii

List of Figures $\quad$ xi

List of Abbreviations $\quad$ xiii

The Stewart Family $\quad$ xv

Introduction 1

Chapter One

'Each Battling in their Respective Spheres': Gender, Duty, and Patriotic Performance

29

Chapter Two

Connecting Home and Front: Patriotic Women Travellers

59

Chapter Three

Speaking Across the Borderline: Intimate Connections and Distance in the Letters of Elizabeth Stewart

\section{Chapter Four}

Words of Comfort and Sorrow: Grief and Remembrance in the Death of George Stewart

\section{Chapter Five}

'Keeping the Homes Going': Families and the Otago Soldiers' and Dependants' Welfare Committee

\section{Chapter Six}

'Our Great Search for Health’: William Downie Stewart's Disability

Conclusion

Bibliography 


\section{LIST OF FIGURES}

Figure $0.1 \quad$ Stewart Siblings $\quad$ xvi

Figure 1.1 Otago Queen Carnival Coronation Ceremony, $1915 \quad 30$

$\begin{array}{lll}\text { Figure 1.2 Otago Queen Carnival Brochure } & 30\end{array}$

Figure 1.3 N.Z. Dominion Gift Parcels post card 49

Figure 2.1 Occupations of New Zealand Women War Workers 68

Figure 2.2 Elizabeth Stewart in VAD uniform, 1916

Figure 2.3 Elizabeth Stewart and group at Brockenhurst dining hall 83

Figure 3.1 Studio Portrait of George and Elizabeth Stewart, 1915

Figure 3.2 George Stewart's grave, Mudros, Lemnos 93

Figure $3.3 \quad$ George and Elizabeth Stewart at Westwood, c. 1912

Figure 4.1 Total items of condolence by recipient 116

Figure 4.2 Items of condolence by sex of correspondent 116

Figure 4.3 Senders of telegrams, sympathy cards and letters by sex of correspondent.

$\begin{array}{lll}\text { Figure 4.4 Westwood, Crookston } & 118\end{array}$

Figure 4.5 Title page, G. H. Stewart Memorial Album 119

Figure 4.6 Map of West Otago District 121

Figure 4.7 Tapanui Farmers' Club Committee, c. 1902

$\begin{array}{lll}\text { Figure 4.8 George Stewart in military uniform } & 125\end{array}$

$\begin{array}{lll}\text { Figure 5.1 Applications for OSDWC relief } & 153\end{array}$

$\begin{array}{lll}\text { Figure } 6.1 & \text { The Maheno at Port Chalmers } & 171\end{array}$

Figure 6.2 William Downie Stewart carried ashore, December 1916172 
Figure 6.3 William and Mary Downie Stewart, Rotorua, 1917

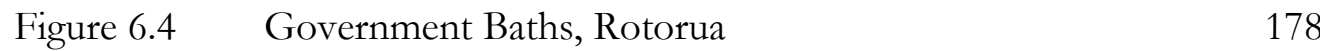

Figure 6.5 William Downie Stewart, London, 1932

$\begin{array}{lll}\text { Figure 6.6 Cabinet Ministers of } 1932 & 184\end{array}$

Figure 6.7 William and Mary Downie Stewart, c. 1941 


\section{LIST OF ABBREVIATIONS}

\begin{tabular}{|c|c|}
\hline AJHR & Appendices to the Journals of the House of Representatives \\
\hline ANZ & Archives New Zealand \\
\hline ATL & Alexander Turnbull Library \\
\hline AWMM & Auckland War Memorial Museum \\
\hline DNZB & Dictionary of New Zealand Biography \\
\hline HL & Hocken Library \\
\hline KMR & Kelso Mounted Rifles \\
\hline NZEF & New Zealand Expeditionary Force \\
\hline MBL & Macmillan Brown Library \\
\hline NZETC & New Zealand Electronic Text Centre \\
\hline NZJH & New Zealand Journal of History \\
\hline NZWCA & New Zealand War Contingent Association \\
\hline OPPC & Otago Provincial Patriotic Council \\
\hline OGPWA & Otago General and Patriotic Welfare Association \\
\hline OSDWC & Otago Soldiers' and Dependents' Welfare Committee \\
\hline OSM & Toitū Otago Settlers' Museum \\
\hline OSWPA & Otago and Southland Women's Patriotic Association \\
\hline ODNB & Oxford Dictionary of National Biography \\
\hline RSA & Returned Services Association \\
\hline VAD & Voluntary Aid Detachment. \\
\hline
\end{tabular}




\section{STEWART FAMILY}

Children of the marriage of William Downie Stewart (1842 -1898) and Rachel Stewart nee Hepburn (1845 - 1878)

Alexander Stewart $(1869-1870)$

Rachelina Hepburn Stewart (1873 -1955) m. George Whitefield Armitage (1868 - 1943)

George Hepburn Stewart (1875 - 1915) m. Elizabeth Herbert (1880 - 1967)

Mary Downie Stewart (1876-1957)

William Downie Stewart (1878 - 1949).

Children of the marriage of William Downie Stewart and Mary Stewart nee Thomson (d. 1929)

Ethel Stewart (1881 - 1933) m. Mr. Nisbet (unknown dates). 


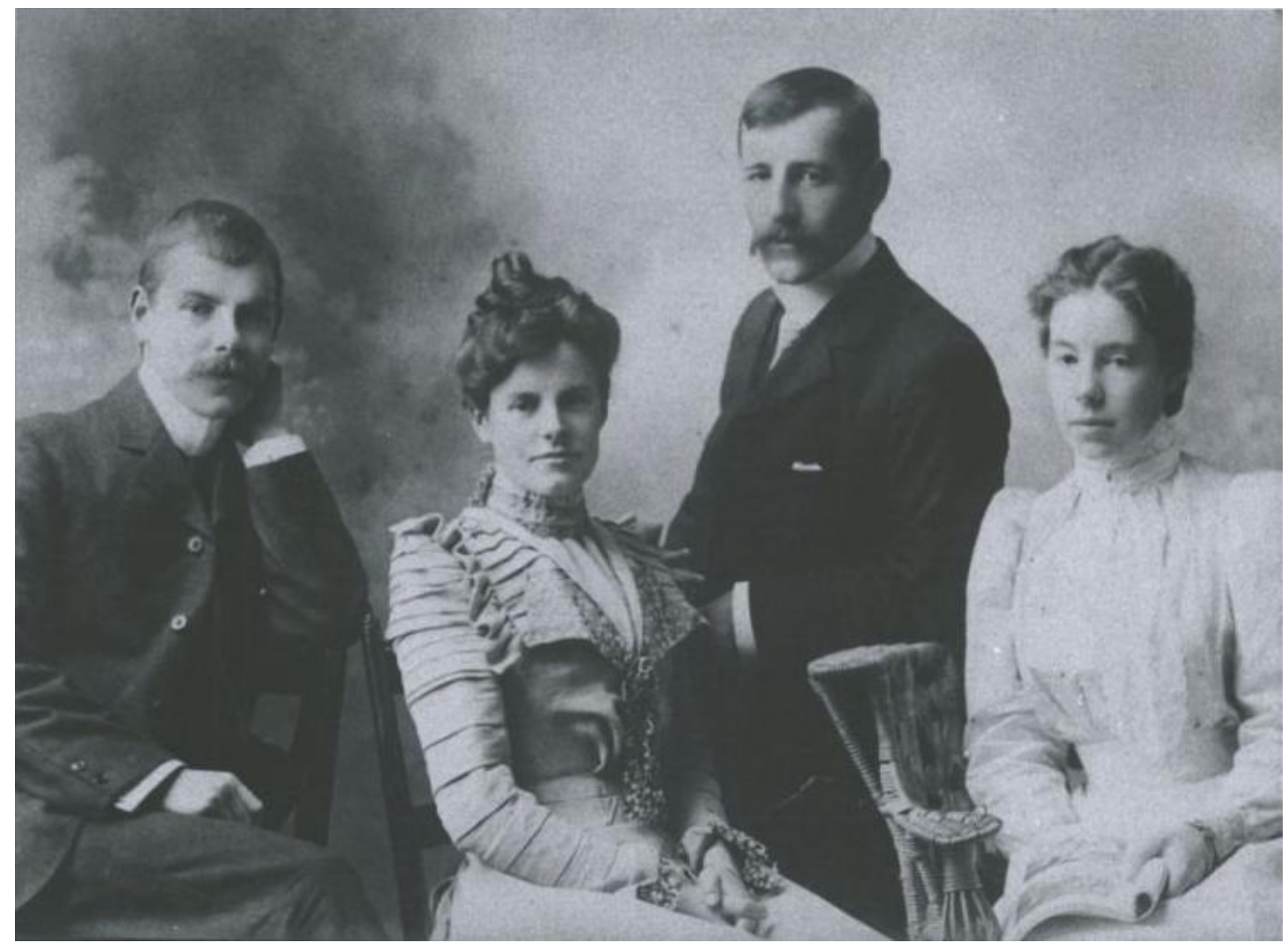

Stewart siblings: William, Rachel, George and Mary

Source: 'Stewart Family,' Hocken Snapshop, URL: http:/ / hockensnapshop.ac.nz/nodes /view/32595 (Hocken Library, Dunedin), accessed 3 March 2014. 



\section{INTRODUCTION}

In Alexandria, Egypt, on 12 November 1915, New Zealand woman Elizabeth Stewart boarded the hospital ship Galeka bound for the island of Lemnos, Greece. A day earlier, Elizabeth, a volunteer nurse at a New Zealand military hospital in Cairo, had received word that her husband Lieut-Colonel George Hepburn Stewart, had been admitted to a Lemnos hospital, dangerously ill with dysentery. Rough seas and gales halted the Galeka's progress and four more days would pass before the ship finally dropped anchor off Lemnos. During these days, Elizabeth endured the torment of not knowing if she would find her husband dead or still living upon her arrival. Meanwhile, back in New Zealand, George's family members went about their daily activities unaware of the family crisis unfolding overseas. George's brother, the Member of Parliament William Downie Stewart, was in military camp at Trentham, north of Wellington, readying himself to follow his brother to the front. Their sister Mary Downie Stewart, living in Dunedin, found her days fully absorbed by her various duties as the president of a large regional women's patriotic organisation. Another sister, Rachel Armitage, married with two children and living in Temuka, South Canterbury, went about her daily tasks as usual, but with thoughts of her two soldier brothers never far from the surface of her consciousness. By November 1915, fifteen months into the First World War, the lives of the Stewart family of Otago were utterly enmeshed in the conflict. The remaining three years of war would exact a heavy personal toll from the members of this family, as it would from the lives of countless others.

This thesis tells the 'family story' of the First World War through the lens of the upper class Stewart family and their social networks. It traces the story of four adult siblings: Rachel Hepburn Armitage nee Stewart, George Hepburn Stewart, Mary Downie Stewart, and William Downie Stewart, as well as George's wife Elizabeth Stewart nee Herbert, through the family's rich archive of correspondence, personal papers and associated collections. In focusing on how the war shaped the lives of a particular family, it shares elements with a collective biography or a family history, however its 
sights remain trained upon larger historical targets. ${ }^{1}$ Like family history, the thesis is concerned with fleshing out the details of individual lives, but at the same time its objective is to open up a wider sphere of experience, using family as its key analytic framework. Thus, in this study, the Stewart family are important not only as a particular family and historical subjects in their own right, but as vehicles to explore the dynamics of family life during the war more broadly. Of course there was no singular 'family experience' of the war: there exists as endless a variety of family stories of the war as there were families. ${ }^{2}$ Nevertheless, it is the central claim of this thesis that families materially, emotionally and symbolically - were integral to the war experience and provide a significant way of comprehending this global event and its devastating human consequences. The aim of this thesis is not to offer a comprehensive or continuous biographical narrative. Rather it is to draw upon aspects of the Stewart family's wartime lives to illuminate larger themes of the First World War experience: family separations, grief and bereavement, duty and patriotism, mobility, philanthropy, religious faith, the lingering shadow of war disability - and the infusion of all of these by the broader categories of gender and class.

\section{The archive}

The Stewart family were remarkable hoarders of the raw materials of history. Their family archive - comprising letters, diaries, newspaper clippings, albums, speeches and photographs - forms the substantive source material for this thesis. Papers relating to the family are divided between two major collections: the William Downie Stewart collection, held by the Hocken Library, Dunedin and the Armitage Family papers, held by the Macmillan Brown Library, Christchurch. The Hocken branch of the Stewart family's personal and political papers alone takes up some 24 metres of shelf space. As well as its extensive nature, the Stewart family archive is unique for its breadth: three generations of family life are documented, dating from the 1850s shipboard journal of

\footnotetext{
1 Innovative works of biography that have influenced the present study include Clifton Crais and Pamela Scully, Sara Baartman and the Hottentot Venus: A Ghost Story and a Biography (Princeton: Princeton University Press, 2009); Desley Deacon, Penny Russell and Angela Woollacott, eds., Transnational Lives: Biographies of Global Modernity, 1700-Present (Basingstoke: Palgrave Macmillan, 2010); Martha Hodes, The Sea Captain's Wife: A True Story of Love, Race and War in the Nineteenth Century (New York: W. W. Norton \& Company, 2006); Kali Israel, Names and Stories: Emilia Dilke and Victorian Culture (Oxford: Oxford University Press, 1999). For New Zealand examples see Margaret Lovell-Smith, Plain Living High Thinking: The Family Story of Jennie and Will Lovell-Smith (Christchurch: Pedmore Press, 1995); Melanie Nolan, Kin: A Collective Biography of a New Zealand Working-Class Family (Christchurch: Canterbury University Press, 2005) and Frances Porter, Born to New Zealand: A Biography of Jane Maria Atkinson (Wellington: Bridget Williams Books, 1995).

2 Whānau (family) along with the wider kinship-based groups of hapū (sub-tribe) and iwi (tribe) formed the fundamental building blocks of Māori society. However, due to its approach centred on a single family and their almost exclusively Pakeha (European) circles, this thesis is primarily a study of Pakeha families' experiences.
} 
the Stewart siblings' maternal grandfather through to Rachel's son George Armitage's detailed record of Canterbury farming life in the 1950s.

As the final surviving sibling, Mary Downie Stewart was the last of her family to have the Dunedin branch of the family papers in her custody. A correspondence which took place in 1956 between Mary and Guy Scholefield, parliamentary librarian and friend of her late brother William, sheds light on their provenance. By the time of her exchange with Scholefield, the responsibility of caring for the family papers and for her brother William's substantial library and pamphlet collection was weighing upon the mind of the aging Mary. ${ }^{3}$ While some of the letters were carefully filed away in a vertical filing cabinet, others lay loosely scattered about the house, in cupboards, on shelves and amongst the leaves of books'. ${ }^{4}$ She wrote to Scholefield in April 1956, 'Today I have been working at the filing cabinet, putting letters from other boxes in, \& feel more \& more that many of these will be valuable as time goes on. Now that my health is not so good, I shall try and get things more definitely into shape. ${ }^{5}$ It is not known whether Mary completed this work of sorting through the family papers before her death that same year. Also unknown is the extent to which she or other family members may have shaped the archive by vetting material considered compromising to the family reputation. After Mary's death in 1957, the Dunedin branch of the family papers were donated to the Hocken Library by her nephews, acting on Scholefield's advice. ${ }^{6}$ The rest of the family papers, probably those which had remained in the custody of Rachel Armitage, passed into the hands of Rachel's eldest son George Armitage. After his death in 1996 the papers were donated to the Macmillan Brown library by his daughter. ${ }^{7}$

The bulk of the Stewart family archive is made up of the family's written correspondence. It is at its richest during periods of separation, such as when Rachel was apart from her soon-to-be husband George Armitage while in England early in the twentieth century. The end of this period with their marriage in 1903 and its consequences for their letter-writing record is encapsulated by Rachel's letter stating 'Here is the last letter of Rachel the spinster to George the bachelor! \& after that they

\footnotetext{
3 William Downie Stewart's substantial private library specialising in law and theories of government was dispersed by sale in 1997. See John Ross, 'Book Buyers and Collectors,' in Book \& Print in New Zealand: A Guide to Print Culture in New Zealand, eds., Penny Griffith, Ross Harvey, and Keith Maslen (Wellington: Victoria University Press, 1997), URL: http://nzetc.victoria.ac.nz/tm/scholarly/tei-GriBook.html, accessed 18 February 2014.

${ }^{4}$ G. H. Scholefield, memorandum, 14 April 1956, Folder 42, MS-Papers-0212, ATL.

${ }^{5}$ Mary to G. H. Scholefield, 20 April 1956, Folder 42, MS-Papers-0212, ATL.

${ }^{6}$ See MB-312-2/16, Macmillan Brown Library (MBL).

${ }^{7}$ Rachel-Mary Perry, personal correspondence with author, 23 March 2014.
} 
were man $\&$ wife $\&$ there was no history of letters etc. darling mine'. ${ }^{8}$ The First World War was another period in which family separation produced a rich outpouring of letters.

In this thesis, the Stewart family's extensive archive of correspondence provides us with glimpses into the emotions, beliefs and values of the members of this particular family, shedding light upon the deeper structures of thought by which they made sense of their wartime experiences. Historians of epistolarity rightly caution against the assumption that personal correspondence can provide us with an unmediated reflection of an individual letter writer's thoughts or emotions. ${ }^{9}$ As scholar of nineteenth-century immigrants' letters David Gerber writes, historians using personal letters as sources 'can be tempted to take for granted that what is written in them is a true account of the letter-writer's condition, intentions, or general state of mind'. ${ }^{10}$ However, as Gerber and other scholars note, historians who use personal correspondence in this way overlook several fundamental aspects of letters as a genre. Firstly, letters are 'dialogical': the product of 'interpersonal relationships', tailored with a particular reader or readers in mind. ${ }^{11}$ As Susan Foley has put it, 'Letters are by definition intended for another reader, and the relationship between sender and recipient is at stake in the exchange'. ${ }^{12}$ This may mean, for instance, that writers may refrain from mentioning certain topics or may deliberately obscure the truth out of a desire to avoid embarrassment or save their reader from worry or distress. ${ }^{13}$ The centrality of relationships to the act of letter-writing means that the purpose fulfilled by writing may outweigh the significance of their content. ${ }^{14}$ The role of letters in sustaining relationships from afar is particularly salient in the context of events like migration or war, in which distance prevented face-to-face contact and letters were the only means of conducting intimate relationships. ${ }^{15}$

\footnotetext{
${ }^{8}$ Rachel to George Armitage, 1 March 1903, MB-312-18/141, MBL.

9 Susan Foley, "'I felt such a need to be loved...in a letter:" Reading the Correspondence of Leonie Leon and Leon Gambetta,' French History \& Civilization 1 (2005): 254-264; David A. Gerber, 'Acts of Deceiving and Withholding in Immigrant Letters: Personal Identity and Self-Presentation in Personal Correspondence,' Journal of Social History 39, no 2(2005): 315-330; Matt Houlbrook, “'A Pin to see the Peepshow": Culture, Fiction and Selfhood in Edith Thompson's letters, 1921-1922', Past and Present, no 207 (May 2010): 215-249; Kate Hunter, 'More than an Archive of War: Intimacy and Manliness in the Letters of a Great War Soldier to the Woman He Loved, 1915-1919,' Gender \& History 25, no. 2 (August 2013): 339-354; Liz Stanley, 'The Epistolarium: On Theorizing Letters and

Correspondences,' Auto/Biography 12 (2004): 201-235.

${ }^{10}$ Gerber, 'Acts of Deceiving and Withholding in Immigrant Letters,' 315.

${ }^{11}$ Ibid.

12 Foley, “'I felt such a need to be loved," 256.

${ }^{13}$ Ibid; Stanley, 'The Epistolarium,' 202.

${ }^{14}$ Martyn Lyons, Reading Culture and Writing Practices in Nineteenth-Century France (Toronto: University of Toronto Press, 2008). Chapter 10 examines the correspondence of French soldiers during the First World War; Foley, "I felt such a need to be loved," 258.

${ }^{15}$ See for instance Gerber, 'Acts of Deceiving and Withholding,' 318; Hunter, 'More than an Archive of War'.
} 
As well as a dialogue, letter-writing is also a performance. ${ }^{16}$ Letters provide spaces for 'self-fashioning' and are 'texts' in the shaping of individual subjectivities. ${ }^{17}$ Letters, as Liz Stanley writes, 'constitute a theatre for the construction and performance of self ${ }^{18}$ In a letter, we see not so much the author's authentic self, but the self-image that they chose to project outwardly. Finally, letters are governed by implicit social codes and conventions, which determined the forms of expression available to the writer, and could also vary considerably depending upon the type or purpose of letter. ${ }^{19}$ With these features of personal correspondence in mind, this thesis will emphasise not only what such letters can reveal of their authors and their own efforts at 'selffashioning', but also the wider functions that the writing and receiving of letters served in the war-time lives of the members of this particular family.

The Stewart family's use of correspondence to overcome distance and maintain the continuity of family ties during wartime was not unique. ${ }^{20}$ Yet, as an archive of First World War correspondence, the Stewart family papers represent a rare survival. First, institutional holdings of personal documents such as letters and diaries tend to be skewed towards documents produced by soldiers. While soldiers' letters were often treasured by families and are now well represented in archival collections, the exigencies of war teamed with the perception that families' letters to soldiers were of little historic value, has meant that letters written by families have nearly always been lost. Second, most institutional collections of soldiers' personal correspondence have been conceived of as archives of war, and are typically confined to letters written during the war years. ${ }^{21}$ By contrast, the breadth of the Stewart archive allows the tracing of individual lives and family relationships across many decades. The span of the family archive allows the thesis to challenge the conventional periodisation of First World War history - by demonstrating the continuities between the war and its preceding decades as well as the ways in which the conflict continued to shape families' lives beyond 1918.

In this thesis, tracing the lives of the members of the well-travelled Stewart family through their correspondence provides a window into mobility and a means of connecting a range of local and global settings. As the authors of a recent innovative

16 Houlbook, "“A Pin to see the Peepshow," 226.

17 Ibid, 225.

18 Stanley, 'The Epistolarium,' 208.

19 Ibid, 207; Foley, "I felt such a need to be loved."”

${ }^{20}$ Hunter, 'More Than An Archive of War,' 339; Rollet, 'The Home and Family Life,' 329.

${ }^{21}$ Hunter, 'More Than An Archive of War,' 342. 
collection of biographical essays on the lives of highly mobile individuals write, 'finegrained' analyses of individual lives across multiple settings have the potential to illuminate 'the larger significance in the individual stories they recount' and show the 'potential of individual life stories to radically explicate the worlds in which they were lived'. ${ }^{22}$ The activities and movements of the individual members of this family demonstrate the capacity of actual families as well as wider ties of kinship to transcend national boundaries. As a general rule, in the present study, connections at local and global levels are found to be more significant than national affiliations. Thus, the thesis follows in the mould of recent scholarship that challenges the primacy of the nationstate as the default unit for historical analysis, by 'thinking under and beyond as well as across the nation'. 23

In addition to one another, the Stewarts sent and received letters from an extended network of family, friends and acquaintances. The Stewart family's surviving archive of correspondence with others of their kinship, friendship and professional circles, provides the means to reconstruct their participation in larger communities and networks of association. Families did not exist in isolation during the war, but were embedded in communities and local and global networks - associations which in this thesis incorporate both epistolary and 'imagined' communities, as well as those bound to particular places. This study reconstructs the wider webs of association of which the Stewart family formed a part with several objectives. First, the Stewart family's correspondence allows the exploration of the aspects of world-view that they shared with others of their primarily middle- and upper-class circles: illuminating questions of class. Next it provides a means of assessing the significance of both new and existing forms of community in shaping family life during the war.

Enhancing the rich picture of early twentieth century family life made possible through the Stewart's archive of correspondence are the records of the voluntary patriotic organisations with which various family members were associated during the war. These provide the opportunity to examine how the members of this particular

\footnotetext{
22 Desley Deacon, Penny Russell and Angela Woollacott, 'Introduction,' in Transnational Lives, eds., Deacon, Russell and Woollacott, 5.

${ }^{23}$ Tony Ballantyne, Webs of Empire: Locating New Zealand's Colonial Past (Wellington: Bridget Williams Books, 2012), 264. For critiques of national histories see also Giselle Byrnes, 'Introduction: Reframing New Zealand History,' in The New Oxford History of New Zealand, ed. Giselle Byrnes (South Melbourne: Oxford University Press, 2009), 1-18; Peter Gibbons, 'The Far Side of the Search for Identity: Reconsidering New Zealand History,' New Zealand Journal of History (NZJH) 37, no. 1 (2003): 38-49.
} 
family translated their personal beliefs into public influence through the spheres of politics and philanthropic leadership. Here, the study blends a biographical study of the leadership of wartime voluntary organisations with a history of the activities of the organisations in question. ${ }^{24}$ The key sets of records examined here are those of the Otago Soldiers' and Dependents' Welfare Committee (OSDWC), for which Mary Downie Stewart was 'lady visitor' during 1916 and 1917, and the Otago and Southland Women's Patriotic Association (OSWPA), which Mary headed from its establishment in 1914 until it was disbanded in 1920. Both were subcommittees of the Otago Patriotic and General Welfare Association, founded in August 1914. ${ }^{25}$

The activities of the OSWPA are reconstructed through records preserved in the personal papers of its long-serving secretary, Jean A. Burt. Burt's papers, which contain the Association's minute books, correspondence, accounts, scrapbooks and memorabilia are now, appropriately, held at Toitū Otago Settlers' Museum, Dunedin, the public base of the OSWPA's activities during the war. The welfare casefiles and correspondence of the OSDWC are held by the Hocken Library. This significant collection preserves over 11,000 First World War casefiles, dating from 1914 through to the 1980s. The OSDWC's casefiles are the largest of only two known collections of patriotic society casefiles to have been preserved in New Zealand. ${ }^{26}$ This thesis's analysis is focused on a sample of just over 200 casefiles from soldiers' dependants who applied for assistance between 1914 and 1919, supplemented by evidence from the OSDWC's minute books and correspondence files. The inclusion of the OSDWC's archive provides the means of widening the purview of the thesis to include the experiences of working-class families whose lives were a world apart from those of the affluent Stewarts. It also avoids the distortions that can occur in studies exclusively based upon family correspondence. As historian Catherine Rollet writes, collections of family letters tend to be skewed towards 'the "positive" side of family life during the war', emphasising the experiences of families 'who, beyond the pain of separation, sustain the link, at all costs, despite every

\footnotetext{
${ }^{24}$ Julia Bush's study of British female imperialist organisations provides a model for such an approach. Julia Bush, Edwardian Ladies and Imperial Power (London: Leicester University Press, 2000), 4.

${ }^{25}$ For the history of the OPGWA and its successor organisations, see Sarah Jane Piesse, 'Patriotic Welfare in Otago: A History of the Otago Patriotic and General Welfare Association 1914-1950 and the Otago Provincial Patriotic Council 1939 - ,' (MA thesis, University of Otago, 1981).

${ }_{26}$ The casefiles of the Akitio Patriotic Society survive in the Tararua District Council Archives in Woodville.
} 
difficulty'. ${ }^{27}$ Welfare casefiles help correct this imbalance by revealing the family story of war to be one of broken connections as well as enduring family ties.

\section{The Stewart family}

The Stewart family's preservation of an archive is a reflection of their class status and self-identification as a family of historic importance in Otago, and of an unusually intense set of sibling relationships. ${ }^{28}$ The four Stewart siblings - Rachelina Hepburn Armitage nee Stewart (1873-1955), George Hepburn Stewart (1875-1915), Mary Downie Stewart (1876-1957) and William Downie Stewart (1878-1949) - were born into a prominent Dunedin family of Scottish Presbyterians. ${ }^{29}$ Born in the 1870 s and educated in the 1880s and 1890s, the Stewart siblings' formative years were squarely in the late Victorian era. Their parents, William Downie Stewart and Rachel Stewart nee Hepburn, formed part of a small cohort of early to mid Victorian European families who climbed the ladder of colonial society through success in farming, business or the professions. ${ }^{30}$ While this family's place as part of the highest strata of colonial society warrants the label 'upper class', such wealthy colonial families were nearer to the British middle classes in their values and work ethic than they were to a leisured aristocracy. As Jim McAloon writes, 'The colonial upper class was essentially similar to - indeed a fraction of - the British middle classes... the differences between aristocratic or gentry consciousness and bourgeois consciousness cannot be overemphasised'. ${ }^{31}$ Thus, while the Stewart family and their circles will be referred to as upper class in this thesis to

\footnotetext{
${ }^{27}$ Catherine Rollet, 'The Home and Family Life,' in Capital Cities at War. Volume 2: A Cultural History, eds., Jay Winter and Jean-Louis Robert (Cambridge: Cambridge University Press, 2007), 316.

${ }^{28}$ For a recent study of sibling relationships see Leonore Davidoff, Thicker Than Water: Siblings and their Relations 1780 1920 (Oxford: Oxford University Press, 2012).

${ }^{29}$ Rachelina was known as 'Lena' before her marriage, and 'Rachel' afterwards. For reasons of consistency, she will be referred to as 'Rachel' in this thesis. Mary was known to her family and friends as 'May', but this thesis will refer to her as 'Mary'. The biographical summaries that follow are indebted to two MA theses on the lives of Mary Downie Stewart and William Downie Stewart (junior) respectively, as well as to William Downie Stewart's own unpublished biography. For Mary Downie Stewart see Yvonne Robertson, 'A Victorian Lady in an Age of Change: the Life of Mary Downie Stewart 1876 - 1957,' (PG Diploma in Arts Thesis, University of Otago, 1990); Yvonne Wilkie, 'Stewart, Mary Downie - Biography,' Dictionary of New Zealand Biography (DNZB), updated 26-Feb-2014, URL: http://www.TeAra.govt.nz/en/biographies/3s34/stewart-mary-downie, accessed 29 March 2014. For William Downie Stewart see Stephanie Dale, 'Gentleman of Politics: A life of William Downie Stewart 1878 - 1949,' (MA thesis, University of Otago, 1981); —_ 'Stewart, William Downie - Biography,' DNZB, updated 26-Feb-2014, URL: http://www.teara.govt.nz/en/biographies/3s35/stewart-william-downie, accessed 13 March 2014. A typescript of William's unpublished autobiography can be found at MS-0985-030/013, Hocken Library, Dunedin (HL). The manuscript of an unpublished autobiography by Mary Downie Stewart held by the Hocken Library has been lost. ${ }^{30}$ For the colonial rich in Canterbury and Otago see Jim McAloon, No Idle Rich: The Wealthy in Canterbury and Otago 1840-1914 (Dunedin: Otago University Press, 2002).

${ }^{31}$ Ibid., 24.
} 
reflect their position in New Zealand society, the family's core beliefs closely resembled those of the late Victorian and Edwardian British middle classes. ${ }^{32}$

The four Stewart siblings grew up as a close-knit family group. Their mother, Rachel Hepburn, died in 1878. ${ }^{33}$ Their father, William Downie Stewart (1843-1899) was fully occupied with his work in a leading Dunedin legal practice and was often called away from home by his duties as an MP. After their mother's death the children were placed in the care of a succession of nannies. ${ }^{34}$ In 1881, William Downie Stewart (senior) married Mary Thomson, with whom he had a daughter, Ethel, born the same year. ${ }^{35}$ In her biography of William Downie Stewart the younger, Stephanie Dale argues that the four original siblings 'deprived of both their mother and their father during his long absences in Wellington, formed themselves into a tightly knit impregnable unit which resented their father's remarriage in 1881 and never accepted their half-sister, Ethel, as one of "them". 36 There are plenty of indications in the family's correspondence that the siblings, with the exception of Ethel, regarded themselves as closer than other families. In a 1909 letter Rachel described herself and her siblings as 'a family more attached to each other than in the average'. ${ }^{37}$ The events of 1914-1918 further cemented already close family bonds, and even led to efforts to repair relations with their estranged halfsister Ethel. As Ethel wrote to Mary in a peace-making letter of 1915: 'Sometimes one feels as if life can never be the same again in so many homes \& one feels as if any bonds shld be strengthened' [sic]. ${ }^{38}$

\footnotetext{
32 The work of British historian Stefan Collini has been influential in this thesis's efforts to reconstruct the values and habits of thought of the Stewart family and their upper-class circles. See Stefan Collini, Public Moralists: Political Thought and Intellectual Life in Britain, 1850-1930 (Oxford: Clarendon Press, 1991).

33 An older brother, Alexander Stewart, died in 1870 aged 5 months. Rachel Armitage later described her mother as 'never very strong' and believed that 'she did not get over the death of her youngest son Alexander Westwood at 6 months from what we should now recognise as meningitis'. MB-458- 2/13, MBL. Medical records suggest that Alexander's death was caused by dysentery while Rachel Stewart's cause of death is recorded as erysipelas. Alison Clarke, 'Rachel Stewart's Photograph and the Tragedies of Victorian Motherhood,' (paper presented at the New Zealand Historical Association Conference, Dunedin, November 2013).

34 Occupying a position on the fringes of this close-knit family were a series of domestic employees. In addition to their much-resented nannies, the family employed several long-standing domestic servants. Eliza Bagshaw, housekeeper to George from 1908 until his death, subsequently moved to live with William and Mary at Ashentree and remained in their service until her retirement in the late 1930s. Eliza Bagshaw inherited the substantial sum of $£ 250$ in George's will, demonstrating the quasi-familial status that some long-term servants attained. Her replacement Chrissie stayed in the household until Mary's death in 1957. Robertson, 'A Victorian Lady,' 43.

35 After the death of William Downie Stewart senior, Mary Stewart and Ethel went to live in England. Robertson, 'A

Victorian Lady,' 14-15.

${ }^{36}$ Dale, 'Gentleman of Politics', 7; Robertson, 'A Victorian Lady', 12.

${ }^{37}$ Rachel to Mrs Collie, 24 October 1909, MB-391-1/2, MBL.

38 Ethel Nisbet to Mary, 2 September 1915, MS-0985-051/003, HL.
} 
The Stewart siblings' father, William Downie Stewart senior, held socially progressive views on women's place in society, and encouraged his daughters as well as his sons to undertake higher education and overseas travel. ${ }^{39}$ Even more importantly, as a wealthy lawyer and politician, he had the financial resources to fund them to do so. ${ }^{40}$ Rachel, the eldest, was a pupil of Otago Girls' High School from 1885 and 1892, before attending a finishing school in Switzerland. ${ }^{41}$ Next, she attended Somerville College, Oxford, as a student of modern history, and in 1896 completed the BA course at Oxford University, although as a woman she could not receive a degree. ${ }^{42}$ While at university, she met and formed friendships with Eleanor Rathbone, a future leader of the British feminist movement, and Margery Fry, later principal of Somerville college and penal reformer. ${ }^{43}$ Like many English female university graduates in this period, after university Rachel joined the Women's University Settlement Scheme, living and working in some of London's poorest districts, and receiving training in 'estate management' under the supervision of prominent social reformer Octavia Hill. ${ }^{44}$ While on a trip home to New Zealand following her father's death, Rachel met George Armitage, a local bank manager, and the pair married in 1903. They began their married life in Temuka, South Canterbury. There, George Armitage continued his work for the bank, while Rachel immersed herself in her philanthropic interests, founding and heading the Temuka branches of the New Zealand Federation of Women's Institutes and the Plunket Society, as well as the St Peter's Anglican Church Ladies' Guild. Their two sons, George Whitefield Armitage and William Stewart Armitage, were both of school age during the

\footnotetext{
${ }^{39}$ Canvassed for his views on women's suffrage in 1885, William Downie Stewart described himself as 'decidedly in favour of extending the franchise for women'. He voted in support of the 1892 bill to introduce women's suffrage. Patricia Grimshaw, Women's Suffrage in New Zealand, rev. ed. (Auckland: Auckland University Press, 1987), 39, 117. His second wife, Mary Stewart, organised with other Dunedin women in support of suffrage in the early 1890s. See Ibid., 50 .

${ }^{40}$ On his death, William Downie Stewart senior had a total wealth of $£ 45,101$, placing him well within the ranks of the colonial rich. McAloon, No Idle Rich, 58.

${ }^{41}$ For biographical information on Rachel Armitage see 'Mrs Armitage Recalls Early Days of Dunedin,' Otago Daily Times, 23 April 1953, 3; Yvonne Wilkie, 'Armitage, Rachelina Hepburn - Biography,' DNZB, updated 30-Oct-12, URL: http://www.teara.govt.nz/en/biographies/3a18/armitage-rachelina-hepburn, accessed 3 February 2013; 'Obituary. Mrs R. H. Armitage,' Otago Daily Times, 17 May 1955, 4.

42 Modern history was the most popular Oxford School among women. Women did not become eligible to receive Oxford degrees until 1920. See Janet Howarth, “In Oxford but...not of Oxford”: The Women's Colleges' in History of the University of Oxford, Volume VII, Nineteenth-Century Oxford, Part 2, eds., M. G. Brock and M.C. Curthoys (Oxford: Oxford University Press, 2000), 265, 271.

${ }^{43}$ For Eleanor Rathbone see Susan Pedersen, 'Rathbone, Eleanor Florence (1872-1946)', Oxford Dictionary of National Biography (ODNB), updated Jan-11, URL: http://www.oxforddnb.com/view/article/35678, accessed 29 January 2014. For Margery Fry see Thomas Hodgkin, 'Fry, (Sara) Margery (1874-1958)', rev. Mark Pottle, ODNB, updated May-07, URL: http://www.oxforddnb.com/view/article/33286, accessed 29 January 2014.

${ }^{44}$ For the women's university settlements see Jane Lewis, Women and Social Action in Victorian and Edwardian England (California: Stanford University Press, 1991), 10. For the settlement schemes see also Seth Koven, Slumming: Sexual and Social Politics in Victorian London (Princeton: Princeton University Press, 2004). For Octavia Hill see Gillian Darley, 'Hill, Octavia (1838-1912)', ODNB, updated May-12, URL: http://www.oxforddnb.com/view/article/33873, accessed 31 January 2014 and F. K. Prochaska, Women and Pbilanthropy in 19th Century England (Oxford: Clarendon Press, 1980).
} 
war. While Rachel herself was heavily involved in patriotic work in her district, few records of this work survive and her most important role in this thesis is as confidante to her younger siblings.

George Stewart attended Otago Boys' High School and then studied agriculture at Lincoln College. After serving a farming apprenticeship at Fairlie, South Canterbury, and completing a tour of Scotland, he purchased his own farm, which he named 'Westwood', at Crookston, West Otago. ${ }^{45}$ In January 1912 he married Elizabeth Herbert, the daughter of a wealthy local land-holder, John F. Herbert, and his wife Agnes Herbert nee Dewe. Their only child, a son, was delivered still-born in December 1913. George, a long-serving member of his local mounted rifle brigade, secured a commission with the Otago Mounted Rifles in January 1915. He departed New Zealand for Egypt with the $5^{\text {th }}$ Reinforcements in June 1915. Shortly afterwards Elizabeth and her sister Agnes Herbert left New Zealand, having organised a passage to Egypt to join him. After spending several months together with Elizabeth in Egypt, George was transferred to Gallipoli in late August 1915. Upon arrival on Gallipoli he was commissioned as Lieutenant-Colonel and transferred to the Canterbury Mounted Rifles. A week later, the New Zealand troops were withdrawn to Lemnos. ${ }^{46}$ On Lemnos, George contracted dysentery and was admitted to the $3^{\text {rd }}$ Australian General Hospital, Mudros, on 5 November. He died there of the same disease, his wife Elizabeth by his side, on 20 November. Afterwards, Elizabeth and Agnes stayed on to work in Egypt as volunteer war workers. In April 1916, the sisters sailed on via France to England where they took up positions as volunteers in the New Zealand military hospital at Brockenhurst. They remained there until demobilisation in 1919, after which they returned to New Zealand.

Mary Downie Stewart attended Otago Girls’ High School followed by Girton College, a Dunedin school 'For the Education of Young Ladies'. ${ }^{47}$ She enrolled at Otago

\footnotetext{
45 'Westwood' was named for the village of the siblings' paternal grandparents, Alexander Stewart (d. 1873) and Mary Downie (d. 1876), near Stirling in Scotland.

46 'George Hepburn Stewart - personnel file,' AABK-18805-W5553-0109462, Alexander Turnbull Library (ATL); Elizabeth to Jack, 6 December 1915, MB-312-14/102, MBL; '1915 - Canterbury,' updated 7 February 2013, URL: http://www.nzhistory.net.nz/war/canterbury-mounted-rifles/1915 (Ministry for Culture and Heritage), accessed 17 February 2014.

${ }^{47}$ Founded in 1886 by Caroline Freeman, the first woman graduate from Otago University, Girton College emphasised 'moral guidance and academic achievement'. See 'Building Archerfield?,' updated 10 July 2012, URL: http://hockensnapshop.ac.nz/nodes/view/8178 (Hocken Library Snapshop), accessed 4 October 2013; Dorothy Page, 'Freeman, Caroline - Biography,' DNZB, updated 30-Oct-12, URL: http://www.TeAra.govt.nz/en/biographies /2f26/freeman-caroline, accessed 17 February 2014.
} 
University in 1896 but appears not to have completed her studies. ${ }^{48}$ Instead, in 1897, she sailed for Scotland in the company of her brother George and their cousin Polly. After Scotland, Mary spent time in the city of Leipzig, Germany, where Polly was studying music. She returned home to New Zealand with Rachel in April 1899. ${ }^{49}$ In between their return and her departure with Rachel on another trip to England in 1902, Mary kept house for George at Crookston; she returned to this role after Rachel's wedding in 1903. While at Crookston, she enjoyed several flirtations of varying seriousness. The most significant of these, with the Reverend John Collie of the Crookston Presbyterian church, resulted in a 'private understanding' between the pair, but Mary continually wavered on the question of their marriage. ${ }^{50}$ Upon her return from a 1908-09 tour of Japan and China, Mary was devastated by the double blow of Collie rescinding his proposal and George announcing he no longer required her services as a housekeeper. ${ }^{51}$ Depressed and at a loose end, Mary resolved to train as a Plunket Nurse, but soon abandoned this line of work. Instead, she moved to Dunedin to live with her brother William at the family home of 'Ashentree'. When William became Mayor of Dunedin in 1913, his sister Mary assumed the public role of Mayoress, accompanying him to public functions and taking an interest in a range of the city's charities. Upon the outbreak of war in August that year, Mary became the president of the Otago and Southland Women's Patriotic Association, a position she held from 1914 through to the organisation's disbanding in 1920. In 1915 she also accepted an invitation to be a 'lady visitor' on behalf of the Otago Soldiers' and Dependants' Welfare Committee, visiting the homes of soldiers' dependants who applied to the Committee for financial assistance. After her brother William arrived home from the war crippled with rheumatoid arthritis, Mary assumed the role of his lifelong carer, companion and 'Parliamentary wife'.

William Downie Stewart, the youngest of the four siblings, attended Otago Boys' High School and then the University of Otago, where he studied law. In 1898, William had joined his father's law firm as a clerk; upon his graduation in 1900 he became a partner. In 1903 he took time off from his legal work for overseas travel, spending time in England before travelling to Japan via St Petersburg, Siberia and

\footnotetext{
48 Robertson, 'A Victorian Lady,' 9.

49 Ibid., 21-26.

50 Ibid., 32.

51 Mary to William, 12 October 1909, MS-0985-006/003, HL; Robertson, 'A Victorian Lady,' 37.
} 
Manchuria. ${ }^{52}$ In 1905, at the age of 27 William made his first bid at entering national politics, standing as a candidate for the Reform Party in the Dunedin South electorate. ${ }^{53}$ Defeated, he resolved instead to enter local politics and was elected to the Dunedin City Council in 1907. ${ }^{54}$ In May 1913 he became mayor of Dunedin. ${ }^{55}$ In December 1914 William succeeded in his second attempt to enter national politics, being elected MP for Dunedin West, at the age of $36 .{ }^{56}$ In 1915 , he took leave from Parliament to go into camp, and left for Egypt with the $9^{\text {th }}$ Reinforcement in January 1916, arriving in France in April 1916. After seeing active service at Armentières and time stationed at NZEF headquarters in France, he was invalided to England in July 1916, suffering from the symptoms of what was later diagnosed as rheumatoid arthritis. ${ }^{57}$ The same condition caused his return home to New Zealand on 20 December 1916. Upon the conclusion of his war service, William returned to Parliament. Although his career was punctuated by periods of prolonged ill-health, William achieved remarkable success as a politician, overseeing a range of senior portfolios including Finance and Customs. After losing his seat in the 1935 election, William devoted his retirement to the writing of history, to which his most notable contribution was a series of biographies of New Zealand judges and politicians. ${ }^{58}$ Like Mary, he never married, and the pair cohabited until William's death from a stroke in 1949.

\section{Families and the First World War}

The family, Erik Olssen writes, was pervasive 'as an ideal and a reality' in early twentieth century New Zealand. ${ }^{59}$ Both the ideals and realities of family life were radically disrupted by the First World War. During the war, over 100,000 New Zealand men were mobilised as part of overseas military forces. The men who made up New Zealand's

\footnotetext{
52 For an account of William Downie Stewart's journey on the Trans-Siberian Railway see 'The Trans-Siberian Railway,' Otago Daily Times, 31 October 1903, 5.

53 Dale, 'Gentleman of Politics', 11-14.

${ }^{54}$ In 1910 he co-wrote his first book. James Le Rossignol and William Downie Stewart, State Socialism in New Zealand (London: Harrap, 1910).

55 'Muncipal Elections,' Otago Daily Times, 1 May 1913, 8.

56 Dale, 'Gentleman of Politics,' 21, 29.

57 Ibid., 37-38.

58 William Downie Stewart, The Right Honourable Sir Francis H. D. Bell, P.C., G.C.M.G., K.C., His Life and Times (Wellington: Butterworth \& Co, 1937); —— William Rolleston: A New Zealand Statesman (Christchurch: Whitcombe \& Tombs Limited, 1940); —— Portrait of a Judge: Sir Joshua Strange Williams P.C. (Wellington: Whitcombe \& Tombs, 1945); - Mr Justice Richmond and the Taranaki War of 1860: A Great Judge Vindicated (Wellington: A. H. and A. W. Reed, 1947). In addition to biographies William also published a history of the Otago club and an edited collection of his grandfather George Hepburn's immigrant journals. ——, A Brief History of the Dunedin Club (Otherwise Known as the Fernbill Club) (Dunedin: Coulls Somerville Wilkie, 1948); ——, ed., The Journal of George Hepburn: On His Voyage from Scotland to Otago in 1850 (Dunedin: Coulls Somerville Wilkie, 1934).

${ }^{59}$ Erik Olssen, An Accidental Utopia? Social Mobility and the Foundations of an Egalitarian Society, 1880-1940 (Dunedin: Otago University Press, 2011), 253.
} 
civilian army were more than soldiers: they were sons, brothers, husbands, fathers, and members of extended families. During the war, competing obligations to the larger imperial community cut across the complex ties of emotion, mutual dependence and duty that bound men to families. These men's departures profoundly impacted their families left behind, in some cases radically unsettling the existing rhythms of family life. Families were forced to live through lengthy separations and the daily agony of the newspaper casualty lists. The family separations of war were particularly sustained in faroff dominions such as New Zealand, where distance prevented the renewal of family ties during home visits on leave, and where the delays in receiving correspondence could be lengthy. In some cases, families' worst fears were realised and kinship ties were permanently severed by wartime deaths. By the end of the war, 18,000 men, or eight percent of the country's men aged between nineteen and forty-five years, had died. Still more men would sucuumb to their injuries, or to war-related illnesses, in the decades that followed. ${ }^{60}$ War-acquired disabilities, both mental and physical, continued to marr the lives of families for decades after the conflict. But while families bore much of the brunt of war and its aftermath, we know little of what they experienced. Compared to the military, operational and political aspects of this conflict, families have been neglected by historians of the First World War.

This study brings together two fields of historical scholarship: the history of the family and the history of the First World War. ${ }^{61}$ While distinct, the two fields overlap in

\footnotetext{
${ }^{60}$ In all 124,211 men were mobilised as part of the First New Zealand Expeditionary Force and of these 100,444 were sent overseas. There were 59,483 casualties, 18,166 of them fatal. These figures do not include men who died of warrelated causes after 1923. Ian McGibbon, ed., The Oxford Companion to New Zealand Military History (Auckland: Oxford University Press, 2000), 80, 367.

${ }^{61}$ For the history of the Pakeha (European) family in New Zealand see Timothy Frank, “'About Our Father's Business": Fatherhood in New Zealand 1900-1940.' (PhD thesis, Auckland University, 2004); Erik Olssen, 'Families and the Gendering of European New Zealand in the Colonial Period, 1840-80,' in The Gendered Kiwi, eds., Caroline Daley and Deborah Montgomerie (Auckland: Auckland University Press, 1999), 37-62; Erik Olssen and Andree Levesque, 'Towards a History of the European Family in New Zealand,' in Families in New Zealand Society, ed., Peggy G. Kooman-Boyden (Wellington: Methuen Publications, 1978) 1-25; Erik Olssen, 'Towards a New Society,' in The Oxford History of New Zealand, ed., W. H. Oliver (Wellington: Oxford University Press, 1981), 250-278, 534-538; Angela Wanhalla, 'Family, Community and Gender,' in The New Oxford History of New Zealand, ed., Giselle Byrnes (South Melbourne: Oxford University Press, 2009), 447-464, 691-697. See also various chapters in Barbara Brookes, Charlotte Macdonald and Margaret Tennant, eds., Women in History: Essays on European Women in New Zealand (Wellington: Allen \& Unwin, 1986) and Barbara Brookes, Charlotte Macdonald and Margaret Tennant, eds., Women in History 2 (Wellington: Bridget Williams Books, 1992). For a demographic history of the New Zealand family during the nineteenth and twentieth centuries, see Ian Pool, Arunachalam Dharmalingam and Janet Sceats, The New Zealand Family from 1840: A Demographic History (Auckland: Auckland University Press, 2007). For the family lives of nineteenth century women see Frances Porter and Charlotte Macdonald, eds., 'My Hand Will Write What My Heart Dictates'. The Unsettled Lives of Women in Nineteenth-Century New Zealand as Revealed to Sisters, Family and Friends (Auckland: Auckland University Press, 1996). For families and the division of household labour during the early twentieth century see Claire Toynbee, Her Work and His: Family, Kin and Community in New Zealand 1900-1930 (Wellington: Victoria University Press, 1995). For the New Zealand home see Barbara Brookes, ed., At Home in New Zealand: Houses, History, People (Wellington: Bridget Williams Books, 2000). Mixed race families form a growing area of research among New Zealand historians. See Judith Binney, “'In-Between” Lives: Studies from Within a Colonial Society,' in Disputed Histories:
} 
a number of ways. Many academic historians of the war have had their interest in the topic piqued by family connections with the war. ${ }^{62}$ The survival of personal testimonies of the war in the form of letters and diaries - now essential to the work of social and cultural historians of the war - often owe their existence to the careful custodianship of families. ${ }^{63}$ Families have been agents in creating the archives of war: past families' ideas about what did, and did not, constitute historically relevant evidence, continues to shape the range of 'archive stories' available to collection users. ${ }^{64}$ Families responding to the Australian War Memorial's efforts to solicit personal records of war in the interwar decades, for instance, frequently withheld soldiers' letters pertaining to 'homefront life' and 'family': believing such topics to be of little historical value, or alternately, being unwilling to offer them up for public perusal. ${ }^{65}$ The emergence of history of the family as a field of academic enquiry has developed in parallel with the growth of family history in its most popular manifestation, in the form of the amateur efforts of genealogists tracing their own family histories. The publication of letters and diaries by the descendants of soldiers now constitutes a minor publishing industry. ${ }^{66}$

The first academic studies of First World War families published during the 1980s focused upon the demographic, health and economic impact of war upon civilian

Imagining New Zealand's Pasts, eds., Tony Ballantyne and Brian Moloughney (Dunedin: Otago University Press, 2006), 93-117; Angela Wanhalla, In/ visible Sight: The Mixed-Descent Families of Southern New Zealand (Wellington: Bridget Williams Books, 2009) and - Matters of the Heart: A History of Interracial Marriage in New Zealand (Auckland: Auckland University Press, 2013). For the nexus between families, charitable organisations and the welfare state see Bronwyn Dalley, Family Matters: Child Welfare in Twentieth-Century New Zealand (Auckland: Auckland University Press, 1998); Bronwyn Labrum, 'Family Needs and Family Desires: Discretionary State Welfare in New Zealand, 1920 1970,' (PhD thesis, Victoria University of Wellington, 2000); Melanie Nolan, Breadwinning: New Zealand Women and the State (Christchurch: Canterbury University Press, 2000); Margaret Tennant, Paupers \& Providers: Charitable Aid in New Zealand (Wellington: Allen \& Unwin; Historical Branch, 1989). For an excellent recent study of families during the 1951 waterfront dispute see Grace Millar, 'Families and the 1951 Waterfront Lockout,' (PhD Thesis, Victoria University of Wellington, 2013).

62 Among the historians referenced in this thesis, Gail Braybon, Graham Hucker, E. P. Malone, Jessica Meyer, Philip Payton, Michael Roper and Alistair Thomson all fit into this category.

${ }^{63}$ During the 1920s and 1930s staff from the Australian War Memorial sent out some 5400 requests to the next-of-kin of Australian Imperial Force soldiers, soliciting personal items. Tanja Luckins, The Gates of Memory: Australian People's Experiences and Memories of Loss and the Great War (Freemantle: Curtin University Books, 2004), 212.

${ }^{64}$ On historians' relationship with the archive more broadly see Antoinette Burton, ed., Archive Stories: Facts, Fictions, and the Writing of History (Durham: Duke University Press, 2005).

65 The next-of-kin who corresponded with Australian War Memorial staff 'considered homefront life, including work, family and leisure, which were popular topics in soldiers' letters, not to be of importance to the War Memorial - and said so in replies... Despite suggestions from the War memorial that the historical value of a document was best determined by the library, many next-of-kin had their own views, and sent only what they considered to be of historical interest'. Luckins, The Gates of Memory, 231.

${ }^{66}$ For examples see Rikihana Carkeek, Home Little Maori Home: A Memoir of the Maori Contingent, 1914-1916 (Wellington: Totika Publications, 2003); N. M. Ingram, ed., In Flanders Fields: the World War One Diary of Private Monty Ingram (Auckland: David Ling, 2006); Bob McCaw, ed., Tale But Partly Told: The World War I Diaries \& Letters of W. T. McCaw (Wellington: McCaw Family, 1998); Allan Marriott, Mud Beneath My Boots: A Poignant Memoir of the Effects of War on A Young New Zealander (Auckland: Harper Collins, 2005); Beth Sutherland, My Dear Chick: A New Zealand Love Story, 1911-1948 (Masterton: Fraser Books, 2008). For a commentary on this publishing phenomenon in the Australian context see Bart Ziino, “'A Lasting Gift to His Descendants”: Family Memory and the Great War in Australia,' History \& Memory 22, no. 2 (Fall/Winter 2010): 125-146. 
populations. ${ }^{67}$ At a similar time, a group of mainly British-based women's and gender historians began to critique an earlier belief that the war had represented a major 'watershed' in British women's status, by seeking to locate changes in women's roles in wartime within longer-term shifts in women's status, or stressing a conservative backlash against women after the war. ${ }^{68}$ In reassessing the war's impact on women's lives, these historians tended to look outside the family to topics such as work, suffrage and the social control of sexuality. ${ }^{69}$ Some 1980 s studies of gender and war were decidedly antagonistic towards women's depiction in family roles. Margaret and Patrice Higonnet, in the 1987 edited collection Behind the Lines: Gender and the Two World Wars, considered a focus on women's grief during wartime harmful as it reinscribed traditional 'feminine values' and reinforced the subordinate position of women as dependants of men - as 'lovers, mothers, or widows' ${ }^{70}$ Later gender histories shared the tendency of these early studies to avoid women's family lives in favour of aspects of women's public lives. ${ }^{71}$ The Australian 1995 edited collection Gender and War is a case in point. While chapters in the volume discuss gender in complex and nuanced ways, only Judith Smart's chapter on Melbourne food riots focuses on women's family roles. ${ }^{72}$ In seeking to locate individuals as gendered subjects within families the present thesis follows the example of leading historians of the family such as Leonore Davidoff and Catherine

\footnotetext{
${ }^{67}$ Richard Wall and Jay Winter, The Upheaval of War: Family, Work and Welfare in Europe, 1914-1918 (Cambridge: Cambridge University Press, 1988).

${ }^{68}$ For commentaries on the existing historical scholarship on women and the First World War in Britain see Gail Braybon, 'Winners or Losers: Women's Symbolic Role in the War Story,' in Evidence, History and the Great War, ed., Gail Braybon (New York: Berghahn Books, 2003), 86-112 and Deborah Thom, Nice Girls and Rude Girls: Women Workers in World War I (London: I.B. Tauris, 1998), chapter 10.

69 A large body of work now exists on British women's war work, for instance. Key works in this field include Gail Braybon, Women Workers in the First World War (London: Croom Helm, 1981); Gail Braybon and Penny Summerfield, eds., Out of the Cage: Women's Experiences in Two World Wars (London: Pandora Press, 1987) Thom, Nice Girls and Rude Girls; Angela Woollacott, On Her Their Lives Depend: Munition Workers in the Great War (Berkeley: University of California Press, 1994). For commentary on the tendency to avoid families in favour of women's public lives and representations in the field of women's and gender history more broadly see Megan Doolittle, “Close Relations?": Bringing Together Gender and Family in English History,' Gender \& History 11, no. 3 (November 1999): 544-545, 547; Alison Mackinnon, 'Fantasizing the Family: Women, Families and the Quest for an Individual Self,' Women's History Review 15, no. 4 (September 2006): 665; Louise Tilly, 'Women's History and Family History: Fruitful Collaboration or Missed Connection?,' Journal of Family History 12, nos. 1-3 (1987): 303-304.

${ }^{70}$ Margaret Higonnet and Patrice Higonnet, 'The Double Helix,' in Behind the Lines: Gender and the Two World Wars, eds. Margaret Higonnet, Jane Jenson, Sonya Michel and Margaret Collins Weitz (New Haven and Yale: Yale University Press, 1987), 42.

71 An exception is Susan Grayzel, who, focusing on Britain and France and drawing primarily upon literary sources, has pointed to the significance of motherhood across a range of categories in which women were represented during the war: including work, sexuality, rape and war-time atrocities against women, anti-war movements, citizenship debates, and remembrance. Susan Grayzel, Women's Identities at War: Gender, Motherhood, and Politics in Britain and France during the First World War (Chapel Hill: University of South Carolina Press, 1999).

72 Judith Smart, 'Feminists, Food and the Fair Price: The Cost-of-Living Demonstrations in Melbourne, AugustSeptember 1917,' in Gender and War: Australians at War in the Twentieth Century, eds., Joy Damousi and Marilyn Lake (Cambridge: Cambridge University Press, 1995), 274-301. For a further study focusing on women's identities as consumers see Belinda Davis, Home Fires Burning: Food, Politics, and Everyday Life in World War I Berlin (Chapel Hill: University of North Carolina Press, 2000).
} 
Hall, who have identified the family as a key site in which gender relationships were formed and enacted. ${ }^{73}$

In focusing on middle- and upper-class mens' relations to family and domesticity the thesis builds on the work of British historian John Tosh. ${ }^{74}$ Whereas previous historians of masculinity focused upon men in largely homosocial contexts such as work, the army, public schooling, all-male societies and sport, Tosh's work demonstrates the centrality of domesticity to the lives of men of the Victorian middle classes. ${ }^{75}$ Nevertheless, like other scholars of the late Victorian and Edwardian eras, Tosh sees men's attachments to domesticity as gradually waning over the latter decades of the nineteenth century in favour of a 'militaristic and robust' brand of masculinity whereby middle-class men eschewed family in favour of imperial adventure and the company of other men. The 'romantic language of heroic masculinity' central to such visions of masculinity was, according to these historians, subsequently dealt 'a fatal blow' in the trenches of the First World War, only to be followed by a resurfacing of the domesticated man after $1920 .^{76}$ This narrative of flight and return seems to have had less of a hold over scholars of working-class masculinity, who emphasise the growing strength of working-class men's identities as providers for their families over the nineteenth century. But the war has tended to form either the end point of, or the backdrop for, such studies rather than their central focus. ${ }^{77}$

\footnotetext{
${ }^{73}$ Leonore Davidoff and Catherine Hall, Family Fortunes: Men and Women of the English Middle Class 1780-1850, rev ed., (London: Routledge, 2002); Leonore Davidoff, Megan Doolittle, Janet Fink and Katherine Holden, The Family Story: Blood, Contract and Intimacy 1830-1960 (London: Longman, 1999), 23.

${ }^{74} \mathrm{John}$ Tosh, A Man's Place: Masculinity and the Middle-Class Home in Victorian England, rev. ed. (New Haven and London: Yale University Press, 1999).

${ }^{75}$ For local examples of this approach see Martin Crotty, Making the Australian Male: Middle-Class Masculinity 1870-1920 (Melbourne: Melbourne University Press, 2001); Jock Phillips, A Man's Country? The Image of the Pakeha Male - A History (Auckland: Penguin, 1987).

${ }^{76}$ Martin Francis, 'The Domestication of the Male? Recent Research on Nineteenth- and Twentieth-Century British Masculinity,' The Historical Journal 45, Issue 3 (September 2002): 640.

77 Ibid., 642. In New Zealand, Erik Olssen argues, men of the skilled working classes increasingly demanded a 'family wage' and 'family... became a fulcrum in the push for higher living standards'. Erik Olssen, Building the New World. Work, Politics and Society in Caversham 1880s - 1920s (Auckland: Auckland University Press, 1995), 82. See also 'Working Gender, Gendering Work: Occupational Change and Continuity in Southern Dunedin', in Sites of Gender: Women, Men and Modernity in Southern Dunedin, 1890-1939, eds., Barbara Brookes, Annabel Cooper and Robin Law (Auckland: Auckland University Press, 2003), 50-90; 376-385. For overseas studies of working-class men and masculinity see Joanna Bourke, Working-Class Cultures in Britain, 1890-1960: Gender, Class and Ethnicity (London; New York: Routledge, 1994); Anna Clark, The Struggle for the Breeches: Gender and the Making of the British Working Class (London: Rivers Oram Press, 1995); Sonya O. Rose, Limited Livelihoods: Gender and Class in Nineteenth-Century England (Berkeley: University of California Press, 1992). Ellen Ross's study of working-class motherhood in London has much to reveal of working-class men's lives. Ellen Ross, Love \& Toil: Motherhood in Outcast London, 1870-1918 (Oxford: Oxford University Press, 1993).
} 
The simplistic narrative of a flight from domesticity followed by a return to the home after the war has been challenged by recent scholars of the First World War. ${ }^{78}$ While not denying the hold that widely circulated images of heroic masculinity and imperial glory had over some men, these scholars emphasise the multiple and conflicted nature of men's identities in wartime. British historian Jessica Meyer, drawing upon the personal writings of British First World War soldiers, suggests that men inhabited dual identities during wartime, aspiring to both the 'heroic' masculine ideals 'associated with the battlefront and the homosocial society of the military sphere' while at the same time seeking to maintain their domestic identities as fathers and sons. ${ }^{79}$ This thesis builds on the work of historians such as Meyer by exploring how men sought to reconcile the competing duties of family and war.

The notion that a feminised home and masculine front constituted two distinct and opposing spheres of experience during the First World War has been a constant of both popular and scholarly accounts of the war for many decades. In the view of Paul Fussell, whose 1975 The Great W ar and Modern Memory was influential in popularising this view, the conditions of trench warfare opened up a 'fissure' in experience and perception between infantry soldiers and homefront populations. The gap in reality between soldiers' experiences and their pre-war ideals and conditioning forced them to undergo a profound psychological adjustment, which was not shared by civilians on the homefront. ${ }^{80}$ Home populations, according to Fussell, displayed little concern for the realities of trench warfare, which were, in any case, comprehensible only to those who had experienced them directly. ${ }^{81}$ According to Eric Leed, writing in 1979, soldiers and civilian populations came to inhabit 'two distinct worlds' during the war. ${ }^{82}$ In Leed's view, the trench soldiers' necessary adjustment to the realities of war involved an 'elimination of ties to the familiar' - in both senses of the word. ${ }^{83}$ By the end of the war, Leed argues, soldiers' sense of detachment from home and family had become an impassable gulf..$^{84}$

\footnotetext{
${ }^{78}$ Joanna Bourke, Dismembering the Male: Men's Bodies, Britain and the Great War (London: Reaktion Books, 1996); Jessica Meyer, Men of War: Masculinity and the First World War in Britain (Basingstoke: Palgrave Macmillan, 2009); Michael Roper, The Secret Battle: Emotional Survival in the Great War (Manchester: Manchester University Press, 2009).

${ }^{79}$ Meyer, Men of War, 2.

${ }^{80}$ Paul Fussell, The Great War and Modern Memory (New York: Oxford University Press, 1975), 87.

81 Ibid.

${ }^{82}$ Eric Leed, No Man's Land. Combat \& Identity in World War I (Cambridge: Cambridge University Press, 1979), 2.

${ }^{83}$ Ibid., 21-22.

${ }^{84}$ Ibid., 22.
} 
In recent decades, a growing body of scholarship has critiqued this received version of First World War history on several counts. The popular myth of the war as a singular narrative of disillusionment and useless sacrifice has been challenged by scholars who have, by contrast, emphasised the diversity of the war experience. On the one hand, scholars have sought to historicise the emergence of the disillusioned soldier as the uniform narrative of the war. ${ }^{85}$ Rather than being an accurate reflection of how all participants in the war viewed the conflict at the time, the 'disenchantment of the infantry soldier', British historian Janet Watson argues, was 'a postwar phenomenon, the product of distance in time and space from wartime experiences ${ }^{86}$ Instead, she argues, the theme of disillusionment can be attributed to the influential writings of a select group of officer-poets and writers, writing not during the war itself but a decade afterwards, in the late 1920s. ${ }^{87}$ In fact, as Watson's work demonstrates, there existed a considerable diversity in the ways that British people represented their involvement in the war at the time, with a significant cleavage occurring along class lines. ${ }^{88}$ This thesis builds upon Watson's work in revealing class as a central aspect of New Zealand families' experiences of war, as well as illustrating the longevity of ideals such as duty and sacrifice well beyond the point by which they are usually held to have dissolved into disillusionment.

Another set of scholars have set about dismantling the home/front binary itself, by demonstrating that the boundaries between home and front, civilian and soldier, were permeable. Scholars of soldiers' wartime correspondence have pointed to the regular flow of letters between frontline soldiers and their families as providing a continuous link between soldiers and their families during the war. As French historian Martha Hanna has argued, 'family correspondence reveals how civilians and combatants, often categorized in our collective imagination as inhabitants of distinct, nonintersecting communities isolated by mutual indifference, remained connected during the war ${ }^{99}$ British historian Michael Roper, whose focus is on soldiers' letters to their

\footnotetext{
85 Dan Todman, The Great War: Myth and Memory (London: Hambledon Continuum, 2005); Janet Watson, Fighting Different Wars: Experience, Memory, and the First World War in Britain (Cambridge: Cambridge University Press, 2004) 86 Watson, Fighting Different Wars, 2.

87 Ibid.

88 Ibid.

89 Martha Hanna, 'A Republic of Letters: The Epistolary Tradition in France during World War,' American Historical Review 108, no. 5 (December 2003): 1340. For other recent histories that seek to dismantle the home/front divide see Bourke, Dismembering the Male; Grayzel, Women's Identities at War; Tammy Proctor, Civilians in a World at War, 1914-1918 (New York and London: New York University Press, 2010); Roper, The Secret Battle; Meyer, Men of War; Watson, Fighting Different Wars; Bart Ziino, A Distant Grief: Australians, War Graves and the Great War (Crawley: University of Western Australia Press, 2007).
} 
mothers, has likewise seen ongoing family bonds as critical to soldiers' ability to endure the conditions of frontline combat: 'The home and battle fronts were linked through families, and it was mothers who often managed the networks between them, effectively underwriting the war effort'. ${ }^{90}$ Recent historians of wartime grief and bereavement, another area of growing interest among First World War scholars, also view familial and quasi-familial bonds as critical to overcoming the psychological and geographic distances that separated home and front. Bart Ziino, writing on Australian families and the Commonwealth War Graves Commission, demonstrates how grieving families formed imaginary or actual links to the distant graves of soldier kin buried overseas. ${ }^{91}$ Families' search for links with graves, Ziino writes 'generated such levels of intimacy between the home and battlefront as to belie the notion that there was no meaningful interaction or understanding between civilian and soldier experiences of the war'. ${ }^{92}$

At the same time, another set of First World War historians have sought to widen the purview of war history beyond the trenches by calling attention to family homes as alternative sites of war. These scholars have challenged earlier soldier-centric approaches to the war, recognising that the effects of war were not confined to the front but reverberated through families and communities. Scholars of bereavement acknowledge that most grieving took place within a familial context, and that the most intimate circle of mourners for a deceased soldier usually consisted of his close family members. ${ }^{93}$ The trauma of war death, as Stephane Audoin-Rouzeau and Annette Becker write, was 'enacted again and again over the course of the war in civilian households at the home fronts, a reminder that war was not distant, but personal. ${ }^{94}$ Much of the war's

\footnotetext{
90 Roper, The Secret Battle, 6.

91 Ziino, A Distant Grief, 5.

92 Ibid., 9.

${ }^{3}$ For scholarly works on grief and the First World War outside of New Zealand see Carol Acton, Grief in Wartime: Private Pain, Public Discourse (Basingstoke: Palgrave Macmillan, 2007); Stephane Audoin-Rouzeau and Annette Becker, 14-18: Understanding the Great War, trans., Catherine Temerson (United States: Hill \& Wang, 2002), Section III; David Cannadine, 'War and Death, Grief and Mourning in Modern Britain,' in Mirrors of Mortality: Studies in the Social History of Death, ed., Joachim Whaley (London: Europa Publications, 1981), 187-242; Joy Damousi, The Labour of Loss: Mourning, Memory and Wartime Bereavement in Australia (Cambridge: Cambridge University Press, 1999); —_, Living with the Aftermath: Trauma, Nostalgia and Grief in Post-War Australia (Cambridge: Cambridge University Press, 2001); 'Private Loss, Public Mourning: Motherhood, Memory and Grief in Australia During the Inter-War Years,'Women's History Review 8, no. 2 (1999): 365-378; Stephen Garton, The Cost of War: Australians Return (Melbourne: Oxford University Press, 1996); Pat Jalland, Changing Ways of Death in Twentieth-Century Australia: War, Medicine and the Funeral Business (Sydney: University of New South Wales Press, 2006); —_, Death in the Victorian Family (Oxford, Oxford University Press, 1996); Tanja Luckins, “'Crazed with Grief?” The Asylum and the Great War in Australia,' in 'Madness' in Australia: Histories, Heritage and the Asylum, eds., Catharine Coleborne and Dolly MacKinnon (St Lucia: University of Queensland Press, 2003), 169-179; - The Gates of Memory; Roper, The Secret Battle, chapter five; Peter Stanley, The Men of Mont St Quentin: Between Victory and Death (Melbourne: Scribe, 2009); Jay Winter, Sites of Memory, Sites of Mourning: The Great W ar in European Cultural History (Cambridge, Cambridge University Press, 1995); Ziino, A Distant Grief.

94 Audoin-Rouzeau and Becker, 14-18, 114.
} 
aftermath played out in families. Family homes became sites where men recuperated from wounds or illness gained during the war, or alternately, where they re-enacted their war trauma upon other family members. ${ }^{95}$ Australian historian Marina Larsson's study of disabled First World War veterans and their families found that, while governments promised to provide generously for disabled men, in reality much of the practical and emotional burden of care fell to kin, particular wives and mothers, within the domestic sphere. ${ }^{96}$

This thesis follows recent scholarship on the family in seeking to extend the definition of family beyond that of the conjugal family unit. ${ }^{97}$ This incorporates a concept of family as a set of practices that can also be applied to a range of non-related individuals, cultural practices, and institutions, or as a process which takes place across the entire life course of its members. ${ }^{98}$ David Morgan describes the family as 'not a thing' but a 'set of practices...and the expectations and obligations that are associated with those practices'. ${ }^{99}$ Describing family in this way opens up the possibilities for exploring the way that the language of kinship became embedded in 'the rituals and practices' of institutions. ${ }^{100}$ In applying flexible concepts of family to the First World War this study follows the lead of historian Jay Winter, who coined the term 'adoptive kinship', in his case to describe the quasi-familial roles performed by those who searched or cared for the bodies of the war dead, and their families at home. ${ }^{101}$ During the war, family, and quasi-familial relationships, the thesis argues, formed a major mechanism by which the geographic and psychological distances between home and battle fronts could be overcome, as well as a key way in which such global linkages were conceptualised.

\footnotetext{
${ }^{95}$ Stephen Garton, 'Return home: War, Masculinity and Repatriation,' in Gender and War, eds., Damousi and Lake, 191-204; Elizabeth Nelson, 'Victims of War: The First World War, Returned Soldiers, and Understandings of Domestic Violence in Australia,' Journal of Women's History 19, no. 4 (Winter 2007): 83-106, 163; Roper, The Secret Battle, chapter 7; Rollet, 'The Home and Family Life'.

${ }^{96}$ Marina Larsson, Shattered Anzacs: Living with the Scars of War (Sydney: University of New South Wales Press, 2009), 21.

${ }^{97}$ Davidoff et. al., The Family Story, 4.

98 Tamara Hareven, 'Family History at the Crossroads,' in Family History at the Crossroads: A Journal of Family History

Reader, eds., Tamara Hareven and Andrejs Plakans (New Jersey: Princeton University Press, 1987), viii, xi-xiii.

${ }^{99}$ David Morgan, Family Connections: An Introduction to Family Studies (Cambridge: Polity Press, 1996), 11.

100 Wanhalla, 'Family, Community and Gender,' 462-363.

101 Winter, Sites of Memory, 30, 44. See also Ziino, A Distant Grief.
} 


\section{First World War scholarship in New Zealand}

This study's most immediate frame of reference is the New Zealand scholarship on the First World War. ${ }^{102}$ Until the 1980s, what studies of New Zealanders' experiences of the First World War existed were limited to military aspects of New Zealanders' participation in overseas theatres of war. ${ }^{103}$ During the 1980 s, social historians drew on personal records such as diaries, letters and oral histories to highlight the experiences of the 'ordinary' soldier in war. ${ }^{104}$ This body of work represented a welcome correction to an earlier tendency to depict the war as a series of military offensives, viewed through the eyes of the military leadership. For such historians, exercised by questions of national identity, the bonds between soldiers were the most significant set of relationships in wartime. In these histories the sense of camaraderie that emerged among soldiers is often depicted as emerging at the expense of soldiers' relationships with their families and other civilians, despite the fact that the personal records such historians drew upon were usually generated out of family relationships. ${ }^{105}$ More recently, Kate Hunter, using Australian and New Zealand soldiers' letters, demonstrates the potential of soldiers' letters to illuminate our understanding of much more than the war itself: including masculinity and men's intimate relationships with family, friends and lovers. ${ }^{106}$ Like Hunter's work, the present study seeks to correct an imbalance in the previous literature on family correspondence in wartime by placing family relationships at the core rather than the periphery of its investigation.

\footnotetext{
102 For surveys of New Zealand's First World War historiography see Deborah Montgomerie, 'Reconnaissance: Twentieth-Century New Zealand War History at Century's Turn,' NZJH 37, no. 1 (2003): 62-79; Gwen Parsons, 'The New Zealand Home Front during World War One and World War Two,' History Compass 11, no. 6 (2013): 419-428. ${ }^{103}$ For a reflection on New Zealand official and regimental histories of the First World War see Ian McGibbon, 'Something of Them is Here Recorded': Official History in New Zealand (Westport: Praeger, 2003), New Zealand Electronic Text Centre (NZETC), URL: http://victoria.lconz.ac.nz/vwebv/holdingsInfo?bibId=714102 (accessed 13 February 2014). An exception are histories of organised labour during the war. See Barry Gustafson, Labour's Path to Political Independence. The Origins and Establishment of the New Zealand Labour Party 1900-19 (Auckland: Auckland University Press, 1980); E. W. Plumridge, 'Labour in Christchurch: Community and Consciousness, 1914 - 1919,' (MA thesis, University of Canterbury, 1979).

${ }^{104}$ For histories drawing upon the letters, diaries or oral histories of First World War soldiers, see Nicholas Boyack, Behind the Lines: the Lives of New Zealand Soldiers in the First World War (Wellington: Allen \& Unwin/Port Nicholson Press, 1989); Nicholas Boyack and Jane Tolerton, In the Shadow of War: New Zealand Soldiers Talk About World One War and Their Lives (Auckland: Penguin, 1990); Glyn Harper, ed., Letters from Gallipoli: New Zealand Soldiers Write Home (Auckland: Auckland University Press, 2011); Jock Phillips, Nicholas Boyack, and E. P. Malone, eds., The Great Adventure: New Zealand Soldiers Describe the First World War (Wellington: Allen \& Unwin/Port Nicholson Press, 1988); Jane Tolerton, An Awfully Big Adventure: New Zealand World War One Veterans Tell Their Stories (Auckland: Penguin Books, 2013).

105 Boyack, Behind the Lines, chapter four; Harper, ed., Letters from Gallipoli; Phillips, Boyack, and Malone, eds., The Great Adventure. For other studies drawing on soldiers' personal testimony to explore questions of New Zealand national identity see Phillips, A Man's Country; Keith Sinclair, A Destiny Apart: New Zealand's Search for National Identity (Allen \& Unwin: Wellington, 1986).

${ }^{106}$ Hunter, 'More than an Archive of War'; Kathryn Hunter, 'Australian and New Zealand Fathers and Sons during the Great War: Expanding the Histories of Families at War,' First World War Studies 4, no. 2 (2013):185-200.
} 
Experiences on the homefront have recently received growing attention from historians, although in New Zealand, most of this work exists in the form of short essays and postgraduate theses. ${ }^{107}$ The homefront remains conspicuously absent from some recent general histories of the New Zealand war experience. ${ }^{108}$ The present thesis builds on this scholarship, while addressing a number of areas largely neglected by New Zealand historians. Studies of public forms of war commemoration and memory currently outnumber studies of private experiences of grief and bereavement. ${ }^{109}$ Ironically, the war has more often been examined through studies of those who opposed it than those who supported it. A number of studies chart the existence of wartime dissent and conflict on the homefront, focusing on areas such as conscientious objection, conscription, and the anti-war movement. ${ }^{110}$ The present study contributes to correcting a bias towards homefront dissent by focusing its attention on homefront patriotism. ${ }^{111}$ With the exception of histories of the labour movement or biographies of labour figures, class remains an under-explored element of the homefront experience which this thesis seeks to illuminate. ${ }^{112}$ The present study adds to several recent theses

107 A range of new perspectives on New Zealand's homefront history are drawn together in John Crawford and Ian McGibbon, eds., New Zealand's Great War: New Zealand, the Allies, \& the Great War (Auckland: Exisle Pub., 2007). Topics covered in the volumes' 32 chapters include women's anti-war movements, churches and religion, war-time welfare, home defence, the Returned Soldiers' Association, farming and the national efficiency movement.

108 The New Zealand Ministry of Culture and Heritage's recent flagship publication on New Zealand and the First World War, written by Damien Fenton, devotes only two out of 111 pages to the home front. Damien Fenton, New Zealand and the First World War: 1914-1918 (Auckland: Penguin, 2013).

${ }^{109}$ For public memorials and commemorations see Graham Hucker, 'Defying Those Who Would Forget: A Hall of Remembrance and Its Narrative,' History Now 9, no. 2 (May 2003): 10-13; Chris MacLean and Jock Phillips, The Sorrow and the Pride: New Zealand War Memorials (Wellington: Historical Branch, 1990); Scott Worthy, 'A Debt of Honour: New Zealanders' First Anzac Days,' NZJH 36, no. 2 (2002): 185-200; —_, 'Communities of Remembrance: Making Auckland's War Memorial Museum,' Journal of Contemporary History 39 (2004): 599-618. For private grief see Sandy Callister, The Face of W ar: New Zealand's Great War Photography (Auckland: Auckland University Press, 2008), chapters 4 and 6; Graham Hucker, 'The Rural Home Front: A New Zealand Region and the Great War, 1914-1926,' (PhD thesis, Massey University, 2006), chapter 9; Kathryn Hunter, “Sleep On Dear Ernie, Your Battles are O'er": A Glimpse of a Mourning Community, Invercargill, NZ, 1914-1925,' War in History 14, no. 1 (2007): 36-62. 110 On the tensions arising from conscription see Paul Baker, King and Country Call: New Zealanders, Conscription and the Great War (Auckland, Auckland University Press, 1988). For the military service boards established to hear men's appeals against conscription see David Littlewood, "Should He Serve?" The Military Service Boards' Operations in the Wellington Provincial District, 1916-1918' (MA thesis, Massey University, 2010). For pacifist women see Megan Hutching, 'The Moloch of War: New Zealand Women Who Opposed the War,' in New Zealand's Great War, eds., Crawford and McGibbon, 85-95. For conscientious objectors see David Grant, Field Punishment No 1: Archibald Baxter, Mark Briggs \& New Zealand's Anti-Militarist Tradition (Wellington: Steele Roberts, 2008); P. S. O'Connor, 'The Awkward Ones - Dealing with Conscience, 1916-1918,' New Zealand Journal of History 8, no. 2 (1974): 118-37. ${ }^{111}$ For those patriotic individuals or groups who channelled their patriotism into anti-German sentiment see Andrew Francis, 'To Be Truly British We Must be Anti-German': New Zealand, Enemy Aliens and the Great War Experience, $1914-1919$. (Oxford; New York: Peter Lang, 2012). For a localised study of public attitudes towards the war see Gwen Parsons, 'Debating the War: The Discourses of War in the Christchurch Community,' in New Zealand's Great War, eds., Crawford and McGibbon, 550-568. See also Steven Loveridge, “'Sentimental Equipment”: New Zealand, the Great War and Cultural Mobilisation' (PhD Thesis, Victoria University of Wellington, 2013).

112 Gustafson, Labour's Path to Political Independence; Plumridge, 'Labour in Christchurch'. In addition, the experiences of working-class diarist and arbitrationist Jack McCullough during the war are examined in Melanie Nolan, ed., War \& Class: the Diary of Jack McCullough (Wellington: Dunmore Publishing, 2009). Gwen Parsons' work on attitudes to war in the Christchurch community forms another exception. See Parsons, 'Debating the War'. 
examining the experiences of First World War veterans, including disabled veterans. ${ }^{113}$ Other recent studies focus on previously overlooked groups, such as children or Māori. ${ }^{114}$ The potential of detailed local studies to illuminate larger themes of the war experience is demonstrated by Graeme Hucker, whose $\mathrm{PhD}$ thesis looks at rural Taranaki during the war, and Susann Liebich, who devotes a chapter of her larger study on reading cultures and communities to the experience of Timaru readers during the war. ${ }^{115}$

With the exception of women who worked as professional nurses, little work exists on New Zealand women's experiences of the First World War. ${ }^{116}$ That Jan McLeod's 1978 BA Hons thesis on the activities of New Zealand women during the war remains the most comprehensive work on this subject is indicative of the paucity of research in this area. ${ }^{117}$ Australian historian Joan Beaumont's observations relating to the lack of research on Australian women's contributions to the war effort also apply in New Zealand. In Australia, Beaumont observes, the First World War is remembered as the conflict in which 'Australian women were universally frustrated by their inability to

\footnotetext{
${ }^{113}$ For veterans see Coralie Clarkson, 'The Reality of Return: Exploring the Experiences of World War One Soldiers after their Return to New Zealand,' (MA thesis, Victoria University of Wellington, 2011); Gwen Parsons, “'The Many Derelicts of the War?" Great War Veterans and Repatriation in Dunedin and Ashburton, 1918 to 1928,' (PhD thesis, University of Otago, 2008). For disabled veterans see Peter Boston “'The Bacillus of Work": Masculinity and the Rehabilitation of Disabled Soldiers in Dunedin, 1919-1939,' (BA Hons Thesis, Otago University, 1993); Elizabeth Walker, “The Living Death”: The Repatriation Experience of New Zealand's Disabled Great War Servicemen' (MA Thesis, Victoria University of Wellington, 2013). For returned soldier settlement schemes after the First World War see Ashley Gould, 'Proof of Gratitude? Soldier Land Settlement in New Zealand after World War I' (PhD thesis, Massey University, 1992); ___ 'From Taiaha to Ko: Repatriation and Land Settlement for Maori Soldiers in New Zealand after the First World War,' War \& Society 28, no. 2 (October 2009): 49-83; Michael Roche, 'Empire, Duty and Land' in (Dis)Placing Empire - Renegotiating British Colonial Geographies, eds., Lindsay Proudfood and Michael Roche (Hampshire: Ashgate Pub., 2005), 135-153.

114 Charlotte Bennett, “Now That The War Is Over, We Have Something Else to Worry Us": New Zealand Children's Responses to Crises, 1914-1918,' (MA Thesis, Victoria University of Wellington, 2012). For Māori and the First World War see James Cowan, The Maoris in the Great War: A History of the New Zealand Native Contingent and Pioneer Battalion: Gallipoli 1915, France and Flanders 1916-1918 (Auckland: Maori Regimental Committee, 1926); Christopher Pugsley, Te Hokowbitu a Tu: The Maori Pioneer Battalion in the First World War (Auckland: Reed, 1995); Monty Soutar, 'Te Hokowhitu-A-Tu: A Coming of Age' in New Zealand's Great War, eds. Crawford and McGibbon, 96-105; Franchesca Walker, "Descendants of a Warrior Race": The Maori Contingent, New Zealand Pioneer Battalion, and Martial Race Myth, 1914-19,' War \& Society 31, no. 1 (March 2012): 1-21.

115 Hucker, 'The Rural Home Front'; Susann Liebich, 'Connected Readers: Reading Practices and Communities Across the British Empire, c. 1890-1930 (PhD thesis, Victoria University of Wellington, 2011), chapter six. For a recent study of Australian soldiers as readers see Amanda Laugesen, 'Boredom is the Enemy': The Intellectual and Imaginative Lives of Australian Soldiers in the Great War and Beyond (Ashgate: Surrey, 2012). Studies of the impact of the war in particular localities form a growing part of the international literature on the war. For overseas examples of this trend see Helen McCartney, Citizen Soldiers: The Liverpool Territorials in the First World War (Cambridge: Cambridge University Press, 2005); Robert Rutherdale, Hometown Horizons. Local Responses to Canada's Great War (Vancouver, Toronto: UBC Press, 2004); John McQuilton, Rural Australia and the Great War: From Tarrawingee to Tangambalanga (Melbourne: Melbourne University Press, 2001); Philip Payton, Regional Australia and the Great War: 'The Boys from Old Kio' (Exeter: University of Exeter Press, 2012).

${ }^{116}$ For New Zealand First World War nurses see Jan A. Rodgers, “'A Paradox of Power and Marginality”: New Zealand Nurses' Professional Campaign During War, 1900-1920,' (PhD thesis, Massey University, 1994); Peter Rees, The Other Anzacs: Nurses at War, 1914-1918 (New South Wales: Allen \& Unwin, 2008); Anna Rogers, While You're Away: New Zealand Nurses at War 1899-1948 (Auckland: Auckland University Press, 2003).

117 Jan McLeod, 'Activities of New Zealand Women During World War One,' (BA Hons thesis, Otago University, 1978).
} 
take an active part in the war effort'. ${ }^{118}$ This view has recently been reiterated by Gwen Parsons in the New Zealand context. During the First World War, Parson writes, 'it was women who were perhaps the most frustrated section of the community in their attempts to assist the war effort... in New Zealand the war was simply too distant and its effects too blunted to force the Government to require women's wholesale participation'. ${ }^{119}$ In New Zealand and Australia, unlike in Britain, vast distances separated home from battlefront, and women were not mobilised en masse to fill places in wartime industries. The relationship between women's suffrage and the war, a major focus for British historians, has been a less urgent priority for research in countries where women were already enfranchised before the war. ${ }^{120}$ Of the topics which engaged the interest of women's historians in Britain, only sexuality and the women's peace movement appeared to hold out promise in the antipodean context. ${ }^{121}$ However, as Beaumont observes in the Australian context, such claims ignored the labour of the many thousands of patriotic workers who actively engaged in the war through voluntary activity. ${ }^{122}$ In focusing upon the lives of the female members of a patriotic family this thesis adds to what is now a growing field of historical research internationally. ${ }^{123}$

\section{Chapter outline}

The organisation of this thesis is thematic and episodic, with each of its six main chapters devoted to a particular aspect of the family story of war. The Stewart family's wartime lives run as a common thread throughout the thesis, linking together what are a series of discrete chapters. Chapter one follows the parallel paths of William Downie Stewart and Mary Downie Stewart from the outbreak of the war, showing how 'duty' to family, community, and nation - translated into the actions of the men and women of this particular family. While men were expected to prioritise the war effort above all other obligations, the belief that women's primary duties lay with family did not change during the war. Next, it demonstrates how Mary Downie Stewart transferred her

\footnotetext{
118 Joan Beaumont, 'Whatever Happened to Patriotic Women, 1914-1918?,' Australian Historical Studies 115 (2000): 273. 119 Parsons, 'The New Zealand Home Front,' 420-421.

${ }^{120}$ For New Zealand women's participation in the paid labour force during the First World War see Sarah Luxford, 'Passengers for the War? The Involvement of New Zealand Women in Employment during the Great War 19141918,' (MA thesis, Massey University, 2005). For women's identities in the early twentieth century see Megan Woods, 'Re/producing the Nation: Women Making Identity in New Zealand, 1906-1925' (MA thesis, University of Canterbury, 1997).

${ }^{121}$ Hutching, 'The Moloch of War'; Jane Tolerton, Ettie: a Life of Ettie Rout (Auckland: Penguin, 1992).

122 Beaumont, 'Whatever happened to Patriotic Women', 273. Bruce Scates' work on the 'emotional labour' of Australian women's wartime work is an important exception. See Bruce Scates, 'The Unknown Sock Knitter: Voluntary Work, Emotional Labour, Bereavement and the Great War,' Labour History 81 (Nov 2001): 29-49. 123 Grayzel, Women's Identities at War; Nicoletta Gullace, 'The Blood of Our Sons': Men, Women, and the Renegotiation of British Citizenship During the Great War (New York: Palgrave Macmillan, 2002); Watson, Fighting Different Wars.
} 
personal beliefs on the appropriate wartime roles for each sex into her leadership of the Otago and Southland Women's Patriotic Association. In assembling and distributing the parcels of 'comforts' to frontline troops that comprised a major aspect of her association's wartime work, Mary Downie Stewart and her fellow volunteers envisaged their work as constructing bridges between families at home and soldiers in the trenches. In resisting the efforts of governments or military officials to assume responsibility for the organisation of parcels, the leadership of women's patriotic organisations insisted that their female volunteers were uniquely qualified to overcome the distances of war. In so doing, the chapter argues, they drew upon enlarged notions of kinship to stake a claim for patriotic women in the war effort.

Chapter two maintains this focus on the work of patriotic women and their organisations by following the movements of Elizabeth Stewart and her compatriots overseas. During the war, some wealthy New Zealand women travelled overseas in the hope of being nearer to relatives in the armed forces or of 'doing their bit' for the war effort. For such women, family and service for the war effort overlapped. These women travellers formed the core workers for a series of voluntary organisations set up to cater for the needs of New Zealand troops overseas. Like members of women's patriotic organisations back in New Zealand, these patriotic volunteers conceived of their work in quasi-familial terms as collapsing the distances between home and front. By transplanting familiar domestic environments onto unfamiliar surroundings, the volunteers at such institutions hoped to replicate the sensations and associations of 'home' for soldiers whose own homes and families were far distant. The presence of upper-class New Zealand women in such institutions, the chapter argues, facilitated the flow of news, information and material and financial aid between the home and front, in the process unsettling the boundaries between these spheres.

Chapters three and four both focus on George Stewart's death as a source of insight into private grief and bereavement. Chapter three examines the aftermath of George Stewart's death through his widow Elizabeth's correspondence with her husband's siblings back in New Zealand. Elizabeth's letters from this period reveal her desire to remain linked to George through her relationship with his siblings, and demonstrate the importance of her wartime correspondence with George's family as an outlet for feelings of grief she was unable to express outwardly in her professional life. 
Elsewhere, however, she is revealed as highly ambivalent about 'home' and the prospect of return. Home, the chapter demonstrates, was not always comforting, and maintaining a distance from home formed one of the devices by which individuals could delay coping with grief. In addition, the chapter documents Elizabeth's growing preoccupation with making contact with her husband through Spiritualism: a common destination of last resort for grieving families during the war. Elizabeth's efforts to bridge the final divide of life and death, the chapter suggests, ultimately proved futile, pointing to the limitations of Spiritualist faith as a source of comfort to the bereaved.

Chapter four follows the reactions to the news of George Stewart's death as it reached his home district of Crookston, West Otago and travelled through the Stewart family's extended networks of friends and family. The chapter's analysis of a significant collection of condolence letters received by George Stewart's family points to the importance of both religious faith and ideals of duty and sacrifice among the members of the Stewart's middle- and upper-class circles. Those who wrote to George's family in praise of his masculine attributes and character were more likely, the chapter argues, to highlight his qualities as a civilian than as a soldier or officer, pointing to the multiple identities men inhabited in wartime. In addition, a family memorial album documenting local reactions to George's death provides a glimpse of the communities of mourning that arose in response to wartime deaths.

The next two chapters delve into the subject of family homes as sites of war and its aftermath. Chapter five uses Mary Downie Stewart's wartime visiting work as a way of illuminating the experiences of working-class Dunedin families whose experiences of the war were far removed from those of the Stewarts and their privileged circles. Sometimes these worlds came together during the war, as when Mary and her fellow visitors visited working-class women in their homes. Nevertheless, the chapter suggests, critical differences existed between the experiences of working-class families and those of more affluent families during the war. Through analysing a sample of the OSDWC's casefiles the chapter charts the impact of the war upon working-class family life in terms of lost income, adjustments to lifestyles and mobility. Middle-class accusations of 'selfishness' targetted at men who elected to prioritise 'personal' attachments to family over the larger cause of the war effort seldom acknowledged the different priorities of 
some men or the greater financial burdens that their departures represented for the families they left behind.

Chapter six concludes the thesis's investigation of the war's impact on family life through the lens of William Downie Stewart's disability. As a high profile disabled man, William Downie Stewart's disability was lived out in the parallel yet overlapping spheres of public life and the family. Nevertheless, this chapter points to a disjuncture between the reality of most disabled men's lives in families, and the public portrayal of disabled men. Praise for the ability of men such as William Downie Stewart to 'overcome' their physical limitations and attain success in public life failed to acknowledge the limited applicability of their cases, while the prevailing emphasis on individual willpower disavowed the family labour that underpinned such men's public successes. The present thesis observes no such strict boundary between the public and the private. By contrast, in exploring the war from the perspective of the family, and the family from the vantage point of the war, it will illustrate that individual participants in this war cannot be separated out from family relationships. 


\section{CHAPTER ONE:}

\section{'EACH BATTLING IN THEIR RESPECTIVE SPHERES'1: GENDER, DUTY, AND PATRIOTIC PERFORMANCE.}

On 27 August 1915, Mary Downie Stewart stepped onto the stage of the Otago Drill Hall along with ten fellow contestants for the title of 'Queen' of the Otago Queen Carnival. Thus concluded the spectacle surrounding the single largest patriotic fundraising event held in the Otago district during the war. In the months leading up to the 'coronation', committees representing each of the eleven contestants organised stalls, parties, dances, and gathered public subscriptions, all in the name of the district's patriotic funds. ${ }^{2}$ The Otago Carnival was one among a series of Queen Carnivals held in New Zealand's main cities in 1915 to raise money for local patriotic funds, and the events surrounding the Otago Queen's coronation embodied the mix of pageantry and serious fundraising intent that Margaret Tennant describes as characteristic of such events. ${ }^{3}$ Organisers of Mary Downie Stewart's 'Queen of Commerce Day' on 31 July promised attendees both a worthy cause and an eclectic range of entertainment, including 'a Super-Dreadnought, with its own motive power', a 'Ladies' Fire Brigade' and 'Old Identities in their Quaint Garb'. ${ }^{4}$ By the campaign's end the residents of Dunedin had raised $£, 127,641$ for the district's patriotic funds. ${ }^{5}$ The brochure introducing the Carnival and detailing the biographies of the competing Queens, framed the war in gendered and familial terms. Describing the district's soldiers as defenders of the home, women and children, it urged its citizens to square the sacrifices of soldiers and families with financial offerings of their own:

\footnotetext{
${ }^{1}$ The title quote of this chapter cites a letter Mary Downie Stewart received from John MacManus, an Otago soldier with whom she corresponded during the war. He wrote 'It is well when one realises how the concentrated energy of the men and women are centred on this great fight, each battling in their respective spheres, a feeling grows more day by day, that it is good to be alive to help in some capacity.' J. E. MacManus to Mary, 15 October 1916, MS-0985051/015, HL. Two pages of this letter have been mis-filed in MS-0985-053/007, HL. For further correspondence and biographical information on MacManus, see chapter five.

2 The surviving minute book of the executive committee behind the campaign for 'Our Soldiers' Queen' indicates the work entailed in organising a Queen Carnival campaign. See 'Our Soldiers' Queen Committee Minute book,' 1915, Misc-MS-0100, HL.

${ }^{3}$ Margaret Tennant, 'Fun and Fundraising: The Selling of Charity in New Zealand's Past,' Social History 38, no. 1 (2013): 56-60.

4 'The Day, The Day, The Day,' Otago Daily Times, 31 July 1915, 1.

5 ‘The Queen Carnival,' Otago Daily Times, 14 September 1915, 3.
} 
They are protecting our homes from the tyranny of the sword. We will protect their homes from the wolf of want. They are guarding our liberties from invasion. We will guard their children from hunger. They are shielding our women from dishonour. We will shield their wives from privation. They are spending the resources of their bodies. We will spend the resources of our wealth. ${ }^{6}$

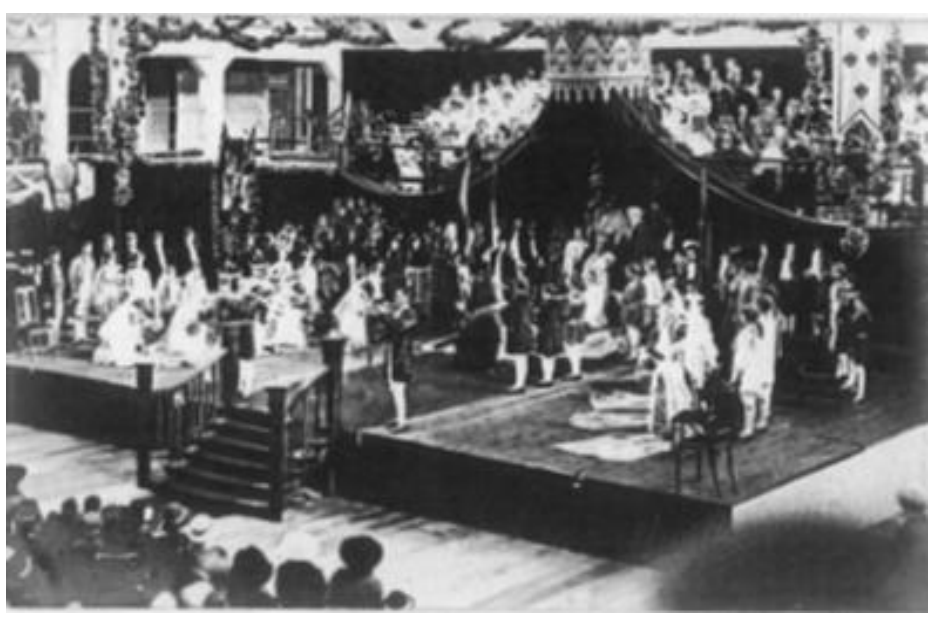

Figure 1.1: Otago Queen Carnival coronation ceremony, 1915

Source: MS-0985-052/007, HL.

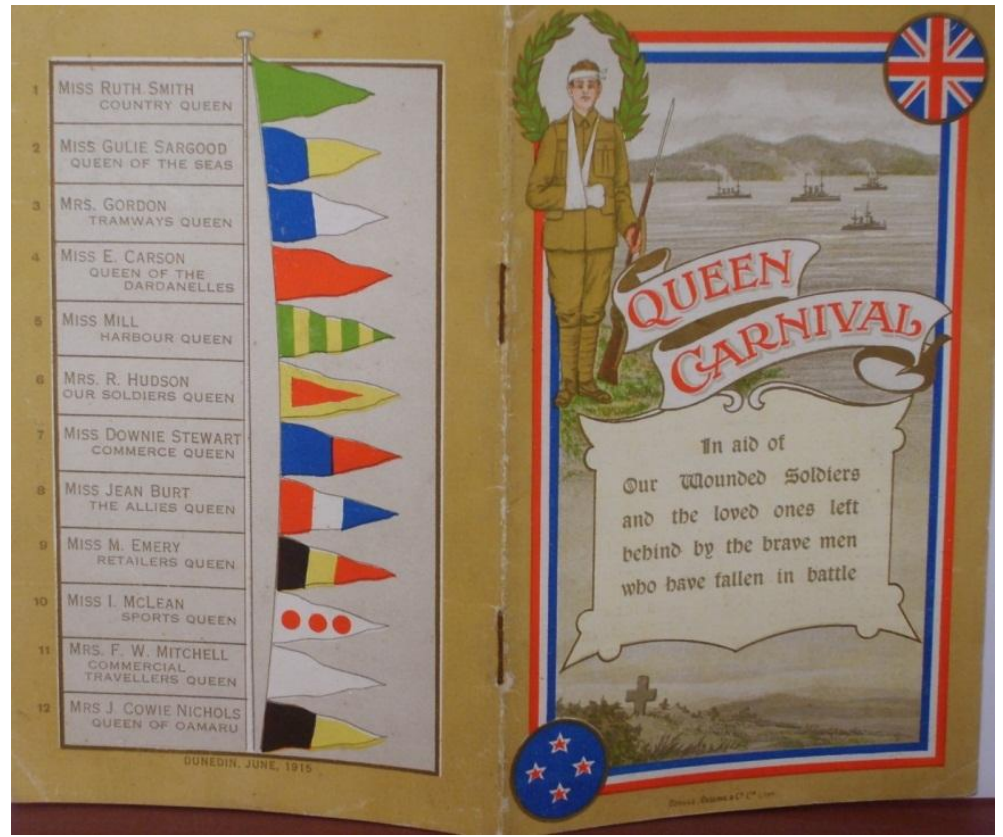

Figure 1.2: Queen Carnival Brochure, 1915

Source: MS-0985-056/017, HL.

\footnotetext{
6 ‘Queen Carnival Brochure 1915,' MS-0985-056/017, HL. Italics in original.
} 
Mary Downie Stewart was overtaken by a rival Queen in her bid to become overall Carnival Queen, although not before her committee had raised $£, 10,030$ pounds towards patriotic funds. ${ }^{7}$ But the fanfare of the Queen Carnival was only one of the ways in which members of the Stewart family made their support for the war effort publicly manifest. This chapter examines the directions in which patriotic duty took two siblings of the Stewart family - Mary Downie Stewart and William Downie Stewart - as a way of illuminating the gendered character of the pressures brought to bear upon men and women during the First World War. Like others in their social circle, the Stewart family regarded the war as a just and necessary cause. And, like members of the middle and upper classes elsewhere, they viewed their own contributions in terms of 'duty' or 'service'. ${ }^{8}$ As Mary Downie Stewart put it in one wartime speech: 'Our present duty is to win the war. To that all must be subordinated."

As members of their society's elite, Mary and William Downie Stewart regarded themselves as holding a special obligation to model patriotic behaviour for others. In this respect they echoed the colonial elites, similarly invested in social hierarchy, whom Australian historian Penny Russell describes as possessing an innate sense of superiority and a view of themselves 'as the natural social and moral leaders of the community'. ${ }^{10}$ Moral leadership required performance. This chapter follows Mary and William Downie Stewart's efforts to exert control and display their support for the war through two of the channels of influence favoured by elites - philanthropy and 'the more conservative end of politics'. ${ }^{11}$ The chapter will first document William's public decision to take leave from Parliament to enlist in the army in 1915, and then focus on Mary's leadership of the Otago and Southland Women's Patriotic Association (OSWPA) from 1914 to 1920.

The Stewarts' idea of appropriate conduct in wartime, the chapter argues, resembles closely the 'moral economy' of duty which British historian Stefan Collini

\footnotetext{
7 The winning 'Country Queen' Miss Ruth Smith raised $f^{33}, 116$ for patriotic funds. 'A Magnificent Result,' Otago Daily Times, 26 August 1915, 6.

${ }^{8}$ British historian Janet Watson argues that while the war was overwhelmingly popular among British people of all classes, critical differences emerged in how different groups in society viewed their contributions to the war, with the key division between those who viewed the war in terms of 'service', and those who saw it as 'work'. This division mostly broke down along class lines. The middle and upper classes typically described their contributions in terms of service. The working classes and some professionals, while generally voicing patriotic sentiments, viewed the war as work. See Watson, Fighting Different Wars, 3-4.

${ }^{9}$ Mary Downie Stewart, speech to departing reinforcement, n.d., MS-0985-053/007, HL.

10 Penny Russell, A Wish of Distinction: Colonial Gentility and Femininity (Melbourne: Melbourne University Press, 1994), 13-14.

11 Ibid. For the support of the Christchurch elite for the war see Parsons, 'Debating the War'.
} 
describes as characteristic of 'dominant Victorian culture'. Victorian moralists, Collini argues, prized the virtue of altruism while exhibiting an 'obsessive antipathy to selfishness'. Within this 'sharp and sometimes exhaustive polarity between altruism and egoism', Victorians applied the concept of duty broadly and viewed it as a system of obligations in which 'only an obligation could beat an obligation', and where 'the only possible alternative to performing one's duty' was to succuumb to selfishness: by 'giving in to temptation or being seduced by one's inclinations [which] were regarded as inherently selfish'. ${ }^{12}$ Such a perspective recognised the possibility that personal inclinations and duty might clash, but adhered to a moral sensibility in which prioritising one's personal desires above one's duty to the wider community could only be selfish. ${ }^{13}$ For William and Mary Downie Stewart, and others in their influential circles, the war posed a moral dilemma to which there were only two possible answers: 'service' or 'selfishness'. But, this chapter argues, wartime duty meant different things for men and women. The conflation of manly duty with military service during the war narrowed opportunities for men. Women, on the other hand, found their opportunities for service broadened, but with the significant proviso that their contributions to the war effort did not conflict with their duties to family.

After tracing the gendered path of duty for men and women, the chapter focuses on the work of the OSWPA as an instance of the women's patriotic organisations founded in towns and communities all over New Zealand upon the outbreak of war. The OSWPA leadership, the chapter argues, regarded women's contributions to the war effort as different but equal to that of men. Rather than disputing separate spheres ideology - the belief that men and women were by nature suited to distinct and complementary spheres - the organisation's leaders took it as justification for their organisations' separate existence. ${ }^{14}$ To illustrate this point, the chapter focuses on the activities of the OSWPA leadership and membership during the war, and chiefly on their production of the parcels of food and clothing known as soldier 'comforts'. The domestic work of parcel production transformed women's ordinary household tasks and skills into patriotic acts, while the dispersed and local

\footnotetext{
${ }^{12}$ Collini, Public Moralists, 63-65. The focus of Collini's study is on male intellectuals of the Victorian era, but the same tendency of thought can also be observed among women. In her study of five key women social reformers in England in the Victorian and Edwardian periods, Jane Lewis calls attention to 'the language of duty to which all subscribed and which underpinned the injunction to serve'. Lewis, Women and Social Action, 5.

${ }_{13}$ Collini, Public Moralists, 65.

${ }^{14}$ For the development of separate spheres ideology in nineteenth-century Britain, see Davidoff and Hall, Family Fortunes.
} 
nature of its organisation enabled a wide range of women to participate. Framing their work in quasi-familial language, the leadership of patriotic women's organisations like the OSWPA insisted that their members' efforts were critical to sustaining links between soldiers and their New Zealand homes. And, in resisting attempts by government or military officials to take over the work of parcel production, they asserted that only female volunteers from a soldier's own country (or preferably, their local district) could undertake the emotional labour of bridging the distances of war.

\section{Soldier Legislators}

When war broke out early in August 1914, William had recently completed a term as Mayor of Dunedin, and was preparing for his second bid at entering national politics. He continued with these plans in spite of the war and was elected as Reform MP for Dunedin West in December 1914. His decision to continue his election campaign was made on the condition that, should he succeed, his party would grant him a leave of absence from parliamentary duties to allow him to go to the front. ${ }^{15}$ His decision was motivated by duty rather than enthusiasm. As he informed Rachel in August 1914, he found the prospect of going to war unappealing: 'No doubt you will approve of my abstention from volunteering in the Expeditionary Force - I might have been tempted had I any chance of a commission but am not keen enough for a troopers discomfort [sic]. ${ }^{16}$

In June 1915, soon after farewelling his brother George as he embarked from Wellington on military service of his own, William made public his intention to join the army as a private in a pair with Liberal member for Westland T. E. Y. Seddon. ${ }^{17}$ The men's pairing was calculated to overcome the political obstacle to their enlistment represented by the Reform Party's slim parliamentary majority. ${ }^{18}$ Their timing was significant. In June 1915, the army was still dependent on voluntary recruitment. By the middle of June, the momentum of a May recruiting boom, spurred on by events on Gallipoli and the German sinking of the civilian passenger liner Lusitania, had begun to

\footnotetext{
15 Stewart, 'Three Generations of New Zealand Politics,' 60.

16 William to Rachel, 17 August 1914, MS-0985-039/002, HL.

17 Thomas Edward Youd Seddon $(1884$ - 1972) was the son of the late Premier Richard (Dick) Seddon and had inherited his Westland seat. For biographical information on the Seddons see T. E. Y Seddon, The Seddons: An Autobiography (Auckland: Collins, 1968).

18 In August 1915, the two main parties in Parliament, Liberal and Reform, combined to form a coalition War Cabinet which remained in power until the 1919 election.
} 
weaken. ${ }^{19}$ Within this context, the two politicians' supporters welcomed their announcement as an act of bipartisan leadership that would encourage others to follow. William's Dunedin friend M. Stuart Holmes, wrote to commend him on his move: 'I feel that I must send you a few lines to let you know how highly I think of the step that you \& Mr Seddon have taken... How can we expect the rank \& file of our country to enlist if some of the more prominent men do not give them a lead; I anticipate that your joint action may be productive of great good to the recruiting. ${ }^{20}$

Responses to William's enlistment reflect the attitude that military service was the most satisfactory form of duty for single, able-bodied men in times of war. Justice Hosking, a Supreme Court Judge who had been a contemporary of William's father, wrote to congratulate William upon his enlistment. In his letter, he confided his own frustration that his age precluded him from any more strenuous form of war service than the giving of patriotic donations. 'I am sure you will satisfy your inmost feelings best by knowing that you are in fact doing something \& that the best by offering yourself. I now \& again vividly realize how contemptible our own part is circumscribed as it is to subscription giving. ${ }^{21}$ The Otago Daily Times' report of the politicians' enlistment claimed that 'they are now both putting their patriotism into practice in the most convincing of all ways. They are responding to the call of the higher duty, to as high a call as any man may resolve to answer... Well becomes it any man, whatever his position in the community, to say in these days that in view of the gigantic struggle in which the Empire is involved it lies upon him as a special duty to make the interests of the Empire his first consideration'.22

William's siblings' correspondence on the matter of his enlistment suggests that the expectations of wartime duty that members of this family projected outwardly reflected genuinely-held beliefs. All four of the Stewart siblings unequivocally supported the war effort, and believed that most men's paramount duty was to enlist. 'You would not have been what you are if you had not answered your country's call when you heard it so clearly', William's sister Rachel told him on the eve of his departure, while Elizabeth also voiced her approval of her brother-in-law's decision: 'every day makes us

\footnotetext{
${ }_{19}$ Baker, King and Country Call, 32. The Lusitania was sunk by a German U-boat in May 1915, with the loss of 1195 lives.

20 M. Stuart Holmes to William, 13 June 1915, MS-0985-003/011, HL.

${ }^{21}$ Justice Hosking to William, 17 June 1915, MS-0985-0985-003/011, HL.

22 Editorial, Otago Daily Times, 12 June 1915, 8.
} 
realize how much men are needed \& it is grand that they should give up everything to answer the call of duty. ${ }^{23}$ George, the only member of the family to dissent from this position, framed his opposition to William's enlistment in the same language of service in arguing that his brother's talents were better suited to politics than the life of a soldier: 'you can serve N.Z. here in a way few can...Then you have this to realize "You are certainly not cut out for a soldier". Your genius I am sure does not lie that way \& I feel sure you going will be misdirected energy'. ${ }^{24}$ Nevertheless, George had expressed his own decision to enlist in terms of duty only months earlier. 'We are now all ready for the call if it comes', he told Mary in a September 1914 letter: 'Better to go \& never return than to fail in one's duty'. ${ }^{25}$ In a letter George wrote to Rachel from a troopship en route to Egypt in June 1915, he revealed that his decision to enlist went against his personal inclinations. 'Here at Sea I am the great Lord High admiral', he wrote humorously. 'Every attention \& men to command on all hands'. But he added: 'Yet, I would chuck it all gladly for Westwood \& my mate'. ${ }^{26}$

Some commentaries on the two politicians' enlistment, such as that of the Christchurch Press, expressed concern at the loss to 'the working strength of Parliament' of the two young legislators. ${ }^{27}$ But most felt that their suspension of their political careers displayed a commendable willingness to sublimate personal or selfish interests to the greater cause of the war effort. The Marlborough Express editorialised 'This is no time for considering personal convenience and amusements; this is the time when all who can should at once rally to the country's cause, and one and all do their share to end a hateful tyranny and bring this awful conflict to a speedy and honourable conclusion...They are temporarily relinquishing political careers of great promise; they are also leaving their professional avocations, at no doubt considerable private loss. But they see their duty clear, and they are prepared to do it'. ${ }^{28}$ The Observer agreed, stating:

\footnotetext{
${ }^{23}$ Rachel to William, 11 January 1916, MS-0985-004/003, HL; Elizabeth to Rachel and Mary, 3 January 1916, MS0985-041/001, HL.

${ }^{24}$ George's letter continued 'Excuse me saying so but there are heaps who can do that job better than you can both through natural gifts \& through mode of life. Also you do not know what you are proposing to do. What with awful comrades, rotten services, want of consideration etc $\&$ all kinds of "narks" you would be dead sorry in no time'. George to William, 4 May 1915, MS-0985-005/003, HL. George also adopted a more interventionist approach to prevent his brother enlisting, approaching Prime Minister William Massey personally on the matter in December 1914. Massey assured George at that time that 'he would not listen to [William] going'. George to Mary, 31 December 1914, MS-0985-048/004, HL.

25 George to Mary, 23 September 1914, MS-0985-048/003, HL.

26 George to Rachel, 19 June 1915, MS-0985-044/001, HL.

${ }^{27}$ In spite of these reservations, the same newspaper nevertheless expressed approval of their actions in enlisting: 'if only for sake of example, they have chosen the nobler part'. 'Progress of the War,' Press, 14 June 1915, 6.

28 'M.P.'s for the Front,' Marlborough Express, 14 June 1915, 4.
} 
'one feels that to be a private soldier in this war is a higher honour than being an MP'. ${ }^{29}$ Other sources welcomed the additional sacrifice represented by the two politicians' decision to enlist as privates rather than seeking officer's commissions. The Free Lance felt that 'their example in starting as denim-clad privates will help to prove that our citizen army is as democratic as the country itself. ${ }^{30}$ While the gesture may have been democratic, both William and Seddon, upon entering Trentham camp in July 1915, quickly rose through the army's ranks. By the time of their departure from New Zealand in January 1916, both men had gained promotion to Second Lieutenant. ${ }^{31}$

\section{Mary Downie Stewart's wartime speeches}

Mary Downie Stewart's wartime speeches as OSWPA president supply further evidence of the gendered variants of duty during the war. Mary delivered the majority of these speeches at the farewell events her Association organised for departing Otago and Southland troops and their families, but she also addressed a range of other gatherings as OSWPA president. The writing of Mary's speeches was a family effort. Some were penned on her behalf by her sister Rachel: 'Will you try \& get some sentences pieced together for me, for Tuesday week, but if you can - send them down in good time so that I can let them simmer', Mary asked in one 1916 letter, adding 'Also if you have any brilliant thoughts about children I have to speak at Kaikorai Valley on Saturday week. ${ }^{32}$ 'My best love \& very best thanks for the speech' she wrote in another 1916 letter to Rachel 'I haven't had time yet to read it all through but I know it will be just what I want'. ${ }^{33}$ Rachel's husband George Armitage was the source for other speeches. Mary wrote to Rachel in 1916: 'I have a "few words" to get ready for Tuesday if show week farewell to the $17^{\text {th }}$ so if George has any ideas ask him to jot them down. I thought of doing on the lines of telling them that by going out to fight - they made us women realize more than ever what a very precious thing our Empire is, etc. ${ }^{34}$

Mary Downie Stewart's speeches cast appropriate behaviour for men and women in wartime in starkly gendered terms. As she told the departing $14^{\text {th }}$ reinforcements in June 1916:

\footnotetext{
29 'Pars About People,' Observer, 19 June 1915, 4.

30 'All Sorts of People,' Free Lance, 18 June 1915, 4.

31 'Military Camps,' Dominion, 10 November 1915, 6.

32 Mary to Rachel, c. 1916, MS-0985-040/004, HL.

33 Ibid.

34 Mary to Rachel, c. September 1916, MS-0985-040/006, HL.
} 
Since the most primitive times - it has always been the same, we women the home keepers must find our duty there, you men, the home guardians, must go out $\&$ meet the enemy. The defence of home \& country has always been the traditional duty of the man... No one pretends it is not hard to let you go, but you would not be the men we love $\&$ are proud of if you had any other instinct - than to go. I know that most men want to go - but for various reasons cannot. So we congratulate you who are able to go, because you have found the way open to fulfil your natural inclinations. ${ }^{35}$

Mary Downie Stewart's speeches make clear her views that, for men, volunteering for the army represented the most noble course of action in wartime and war and the pinnacle of masculine achievement. '[T] he grandest work for all healthy men today is to go forth willingly \& meet the enemy... it is a privilege that most men instinctively claim as their right'. ${ }^{36}$ Elsewhere, she voiced her belief that war operated as a social leveller in offering all men the opportunity to realize their manly potential. '[W] hen you set out with your regiment you will come into your own, \& whenever you may have failed in the unequal battle of the past you will have an opportunity to make good there. ${ }^{37}$ Her praise of departing men for choosing service over self-interest echoed reactions to William's enlistment. She told the men of the 16th reinforcement, departing in August 1916: 'with you (as with all true Britishers) the safety of the Empire comes before all personal preferences....We cannot tell you how it gratifies us to know that you have chosen sacrifice rather than selfishness'. ${ }^{38}$ Likewise, in her contribution to a locallyproduced piece of recruitment propaganda, The Call of the Camps, Mary expressed the gratitude of Otago women for the 'heroic men of our land, who have chosen the path of honour, rather than that of selfish ease and comfort. ${ }^{39}$

Idealised notions of home were central to propaganda efforts both overseas and in New Zealand. In wartime London, historian Catherine Rollet has argued, 'appeals for volunteers centred on the defence of hearth and home', and in doing so drew upon ideals of home that were 'immensely resonant in Britain' in $1914 .{ }^{40}$ The sense of

\footnotetext{
35 Mary Downie Stewart, speech to $14^{\text {th }}$ reinforcement, c. June 1916, MS-0985-053/007, HL.

36 Mary Downie Stewart, speech to departing reinforcement, n.d., MS-0985-053/007, HL.

${ }^{37}$ Ibid.

${ }^{38}$ Mary Downie Stewart, speech to $19^{\text {th }}$ reinforcement, c. November 1916, MS-0985-053/007, HL.

${ }^{39}$ F. S. Fanning, ed., The Call of the Camps: The Only Way, a Man's Way To Save the State (Wellington: Blundell Press, 1916), 4-5.

40 Rollet, 'The Home and Family Life,' 317.
} 
imminent threat to British homes was intensified through widely-circulated atrocity stories which depicted the Germans as perpetrators of the rape and mutilation of Belgian women and children, and called upon British men to enlist to avenge Belgian women and protect their own womenfolk from a similar fate. ${ }^{41}$ Similar claims were repeated in several of Mary's wartime speeches. Thus, Mary informed the men of the $14^{\text {th }}$ reinforcement, departing in June 1916, that 'you guard us effectually as though you stood with fixed bayonets by our doors', while the 19th reinforcements were told: 'We realize it is because you are such men that we need not fear the brutalities of the Hun'. ${ }^{42}$

Several highly publicised incidents during 1915 further fuelled this sense of public outrage against Germany. In October of that year, a German firing squad executed British Red Cross nurse Edith Cavell for abetting the escape of allied soldiers from German-occupied Belgium. ${ }^{43}$ The German sinking of the Lusitania in May 1915 was followed five months later by the German torpedo attack of the hospital ship Marquette, causing the deaths of many passengers, ten New Zealand nurses among them. It was in this context that Mary Downie Stewart called upon the men of one departing reinforcement to avenge the "barbarous treatment meted out to other women or base attacks on our own sisters on their errand of mercy'. ${ }^{44}$ In other speeches Mary referred directly to Cavell's death as a motive for enlistment, while threatening that the present demand for male recruits, if not met, might cause traditional gender roles to be overturned: 'I guarantee that if men can't be secured in sufficient numbers then we must have a regiment of women. The cry of E. Cavell's blood cannot be silenced \& whilst vengeance is not ours the duty is ours to put beyond them of doing harm - if capable of allowing themselves to do this horrible thing that [will] never be forgotten'. ${ }^{4}$

Mary's wartime speeches cast women as performing patriotic service equivalent to, although different from, that of their menfolk. 'We men \& women are equal workers for the great struggle for right', she told the men of the 21 st reinforcements, 'Our work

\footnotetext{
${ }^{41}$ Gullace, The Blood of Our Sons, 46-51; Grayzel, Women's Identities at War, 50, 63-66. Similar atrocity stories began to appear in the New Zealand newpapers from as early as November 1914. See Hucker, 'The Rural Home Front,' 60, footnote 49.

42 Mary Downie Stewart, speech to 14th reinforcement, c. June 1916, MS-0985-053/007, HL; Mary Downie Stewart, speech to 19 th reinforcement, c. November 1916, MS-0985-053/007, HL.

${ }^{43}$ For international reactions to Cavell's death see Katie Pickles, Transnational Outrage: The Death and Commemoration of Edith Cavell (Basingstoke: Palgrave Macmillan, 2007).

${ }^{44}$ Mary Downie Stewart, speech to departing reinforcement, n.d., MS-0985-053/007, HL.

${ }^{45}$ Mary Downie Stewart, speech to 23rd reinforcement, c. March 1917, MS-0985-053/007, HL. In Britain, wartime propaganda frequently sought to capitalise upon male gender anxieties to pressure men to enlist through threats of gender role reversals of this kind. Gullace, The Blood of Our Sons, 45.
} 
may be different but our spirit is the same, \& we each strive to give of our best'. ${ }^{46}$ One of women's first duties in wartime, Mary's speeches made clear, was simply to prevent their own 'selfish' claims upon their menfolk's affection forming a barrier to men's enlistment. 'I think few true women stand in their men's way' she informed one group of departing troops. ${ }^{47}$ Mary's comments point to a variant of women's patriotic duty prominent in debates over women's wartime service overseas: that of the soldier's mother who sublimated her personal interests to such a degree that she was believed to have willingly and even 'gladly' sacrificed her own sons for the larger cause of the war effort. ${ }^{48}$ Mary voiced the appropriate sentiment on behalf of soldiers' mothers in one wartime speech as to: 'Be Proud. Proud that you gave a son to stand as a shield between his folks \& shame. Proud that you gave a son to fight for England. ${ }^{, 49}$

While Mary Downie Stewart's speeches called upon women to do their duty in any way open to them, she shrank from the more radical possibilities for women's participation in the war presented by women's mass mobilisation into the workforce overseas. She believed that women in New Zealand should only replace men in their jobs as an option of last resort. Mary addressed several 1916 meetings of the Dunedin branch of the Women's National Reserve as invited speaker. The Reserve's aims, as a newspaper report of the meeting summarised them, were to 'cut the ground from under the feet of many who think their services are indispensable here' by compiling a register of women willing to take on men's jobs to free more men for frontline duties. Nevertheless, as the same report was careful to emphasise, such women would be motivated 'purely from patriotic motives', rather than self-interest, profit or career advancement, and such measures would be strictly temporary: 'until such time as the men who left them (or other men requiring work) come back'. ${ }^{50}$ Such sentiments echoed an attitude to women's war work prevalent also in Britain. As Watson notes in the British context, 'Only patriotism - not personal benefit - was a safe motivation for challenging pre-war gender mores' ${ }^{51}$ However, even with these heavy qualifications, Mary remained ambivalent about the Reserve's objectives, confessing privately to William that she was 'trying to make up my mind that it is going to be a good thing,

\footnotetext{
46 Mary Downie Stewart, speech to 21st reinforcement, c. January 1917, MS-0985-053/007, HL.

47 Mary Downie Stewart, speech to departing reinforcement, n.d., MS-0985-053/007, HL.

${ }^{48}$ For a discussion of the patriotic mother in Australia, see Damousi, The Labour of Loss, 30. For Britain and France, see Grayzel, Women's Identities at War, and Gullace, The Blood of our Sons.

${ }^{49} \mathrm{Ibid}$. On the theme of maternal sacrifice see Woods, 'Re/producing the Nation,' 97-100.

50 'Women's National Reserve,' Otago Daily Times, 27 March 1916, 2.

51 Watson, Fighting Different Wars, 34.
} 
though the time for it is not ripe yet, and I hope never will be'..$^{52}$ Thus while her speech to the Reserve called upon women to serve the war effort, she informed them replacing men in their jobs would be necessary only as a last resort: 'I do not mean that women shd. rush hysterically to try and do a man's work unless it is necessary. ${ }^{, 53}$

Rather than replacing men in their jobs, women's first and foremost duty in wartime, Mary informed Women's National Reserve members, was to concentrate on the forms of national service they could perform in their own homes:

We all recognise the fact that the home is the very foundation of the state, that round the home cling the highest influences that go towards the building up of the character of our citizens. This we know is woman's best \& highest sphere. It is the most natural \& the most ideal. The first \& most urgent duty of many women is to stay in their own homes \& look after their children; it has always been so, and today it is more than ever her highest duty, for there never was a time when child life was as valuable to the state as it is today, ${ }^{54}$

During the war, mounting casualty rates and a high rate of rejections for military service exacerbated existing concerns about the falling birth rate and quality of the existing racial stock. ${ }^{55}$ In this context, as Mary's speech suggests, the task of repopulating the nation appeared even even more urgent. Such fears are evident in the notes Mary prepared for a speech to pupils of Otago Girls High, in which she claimed that 'To take the place of those who have fallen we must have citizens as fit as we can possibly help them to be. And I feel that in trying under the able instruction of Miss B. to develop your bodies in the best way you are doing your "bit" to keep our race on top in the forefront of the nations. I dare say you have noticed/heard what a large number/proportion of volunteers for service have been rejected to their keen disappointment'. ${ }^{56}$

\footnotetext{
52 Mary to William, 15 February 1916, MS-0985-006/004, HL.

53 Mary Downie Stewart, speech to the Dunedin Branch of the Women's National Reserve, March 1916, MS-0985053/007, HL.

54 Ibid.

55 Philippa Mein Smith, Mothers and King Baby. Infant Survival and Welfare in an Imperial World: Australia 1880-1950 (Basingstoke: Macmillan Press Ltd, 1997), 78; Grayzel, Women's Identities at War, chapter three. Both Mary and Rachel had good cause to be well-versed in pro-natalist ideology. Sir Frederick Truby King, founder of the Plunket Society, was a family friend. Mary had completed Plunket nurse training while Rachel had a life-long association with the Society and founded its Temuka branch.

${ }^{56}$ Mary Downie Stewart, speech to pupils of Otago Girls' High School, n.d., MS-0985-053/007, HL.
} 
Mary Downie Stewart's position struck to the heart of the contradictions confronting women in public life in a period in which their claims to participation in the public sphere were centred squarely upon virtues and qualities associated with the home. Mary was not unaware of the tensions inherent in her own position, as an unmarried and childless woman publicly espousing the virtues of homelife and motherhood. She informed a meeting of the Dunedin branch of the Mother's Union that she felt 'diffident' about accepting their invitation to speak 'as I couldn't help feeling that it was much more fitting that I shld. come as a learner to a Union such as this, a Union of women who as mothers, have tasted all the deepest experiences of life, the glory \& the joy of motherhood' ${ }^{57}$ Mary's predicament echoed those faced by women engaged in public life elsewhere. As Russell notes of the women of Australia's colonial elite, the task of 'projecting outwards the private inner virtues of homelife and motherhood' posed significant contradictions for publicly prominent women in an era where women's basis to authority as 'guardians of morality and order' rested upon their 'rhetorical separation...from the public world'. ${ }^{58}$ Given such pressures, it is hardly surprising that single women like Mary Downie Stewart tended to monopolise the leadership positions available to women in this period. Indeed, the multiple authorship of Mary's speeches makes it tempting to speculate upon the degree to which Mary may have functioned as a mouthpiece for the views of her older sister Rachel, whose own fulfilment of the maternal ideal precluded her from a greater level of participation in public life.

However, as will be argued in the next part of this chapter in relation to the OSWPA's wartime work, the qualities of 'mothering' were malleable enough to be inserted into the objectives of women's organisations. Thus, while some of Mary's speeches focused strictly upon women's reproductive capacities, in others of her speeches women's capacity for 'motherly' influence stretched well beyond the home. Here, Mary's speeches reiterated a position often voiced by women leaders of this period. As Julia Bush has argued of the elite British women who populated the leadership of Edwardian imperialist ladies' organisations of this era, despite their 'basically conservative gender politics' such leaders rejected claims that women's interests should be confined to their own homes and families, and rather drew upon

${ }^{57}$ Mary Downie Stewart, speech to the Dunedin branch of the Mother's Union, c. 1918 or 1919, MS-0985-053/007, HL.

58 Russell, A Wish of Distinction, 59-60. On this point see also Lewis, Women and Social Action, 17, and Prochaska, Women and Philanthropy, 226. 
essentialised notions of femininity to call for greater female agency in public life. ${ }^{59}$ This translation of 'motherly' influence into societal power is evident in a speech Mary delivered to the Dunedin branch of the Mother's Union shortly after the war. 'We all know how each home is made by the mother, she sets the standard for the whole house $\&$ her influence permeates instinctively every room \& she feels her influence as soon as she goes into it... And as she rules her home individually so collectively women rule the world'. ${ }^{60}$

Mary's speeches make it clear that, for those women whose time was not fully absorbed by family duties, the way remained open for other forms of wartime service. As she told the Women's National Reserve, 'there are many of us who, for different reasons, have no special claims on our time. Our men folk have gone out to fight, and in the meantime our home ties are not pressing... As far as enlisting comes into the question surely we women have just as great opportunities as the men for proving ourselves ready to help the nation'. ${ }^{61}$ She stated in another speech: 'Patriotism to be really sincere, should mean willingness to serve. And how are we going to serve? That is a question for each one of us to answer individually for there are many ways open to us. Our country needs the service of its women every bit as much as it needs its men. ${ }^{62}$ Mary's answer to the question 'how are we going to serve?' lay in the organisation she led from its formation in 1914 to its disbanding in 1920 - the Otago and Southland Women's Patriotic Association. Its activities form the subject of the remainder of this chapter.

\section{Otago and Southland Women's Patriotic Association}

The Otago and Southland Women's Patriotic Association was founded on 9 August 1914 at a meeting of Dunedin women in response to a call for volunteers to help equip Otago troops with kits and outfits. ${ }^{63}$ Mary Downie Stewart was initially voted a vice-

\footnotetext{
${ }^{59}$ Bush, Edwardian Ladies and Imperial Power, 73.

${ }^{60}$ Mary Downie Stewart, speech to the Mother's Union, c. 1918 or 1919, MS-0985-053/007, HL. The Mothers' Union, associated with the Anglican church, was founded in England in 1876. By 1897 every New Zealand diocese had its own branch. The Mother's Union emphasised the moral associations of home life and sought to influence public policy where it impinged upon family life. See Elizabeth Hay, 'Association of Anglican Women 1886-', in Women Together: A History of Women's Organisations in New Zealand Nga Ropu Wabine o te Motu, ed., Anne Else (Wellington: Daphne Brasell Associates; Department of Internal Affairs, 1993), 165-167.

${ }^{61}$ Mary Downie Stewart, speech to the Dunedin Branch of the Women's National Reserve, 1916, MS-0985-053/007, HL.

62 Ibid.

63 'The War. Meeting of Dunedin Ladies,' 11 August 1914, Otago Daily Times, 2 in OSWPA Minutes, AG-73, Jean Burt Papers, Toitū Otago Settlers' Museum (OSM). The Otago and Southland Women's Patriotic Association (OSWPA)
} 
president of the organisation, but became its president after the mayoress Mrs J. B. Shacklock turned down the role. ${ }^{64}$ Upon the formation of a men's patriotic organisation for the Otago region, the Otago Patriotic and General Welfare Association (OPGWA) the following week, the OSWPA was subsumed into the organisational structure of the new organisation, within which it formed a sub-committee. ${ }^{65}$ Thus, the Otago patriotic societies followed the gendered pattern of organisation characteristic of patriotic organisations elsewhere in the country. ${ }^{66}$ Yet, aside from the male committee's oversight of its finances and the occasional intervention of the male executive into its leadership, the OSWPA maintained its own separate identity and all-female executive committee, raised its own funds, and generally operated with a high degree of autonomy from its male 'parent' organisation. And, as seen in the following paragraphs, its female leadership justified their organisation's separate existence through claims that their patriotic work capitalised upon attributes they regarded as uniquely feminine. ${ }^{67}$

As suggested by the common choice of mayors or mayoresses as heads of such organisations, the leadership of patriotic organisations was dominated by members of local elites. The OSWPA's leadership list, as one of its historians has put it, 'read like a page from a Social Register'. ${ }^{68}$ The OGPWA's committee comprised a representative scattering of Dunedin's most wealthy and influential men, including prominent businessmen, merchants, importers and manufacturers and the chairmen or managing directors of major companies, newspaper men and prominent members of the legal and medical professions. ${ }^{69}$ Many of the men who joined the OGPWA's executive already exercised some degree of influence in local and national life through involvement in

was variously known as the 'Otago Women's Patriotic Association' and 'Dunedin Women's Patriotic Association'. For reasons of consistency, I refer to it throughout this thesis as the OSWPA.

64 Mary explained to Governor General's wife Lady Annette Liverpool that Mrs Shacklock 'is very delicate \& cannot take any active part in the work'. Mary to Annette Liverpool, c. 1915, MS-0985-053/003, HL.

${ }^{65}$ For an account of the founding of the OGPWA see 'Otago Patriotic Association,' Otago Daily Times, 15 August $1914,10$.

66 Bronwyn Dalley, 'Women's Patriotic Associations 1914-1918, 1939-1945,' in Women Together, ed., Else, 306-308.

67 The leadership of Edwardian female imperialist organisations also justified the existence of separate ladies' imperialist organisations due to their focus on fields of work in which they believed, as women, they had special expertise. Bush, Edwardian Ladies and Imperial Power, 73.

${ }_{68}$ Piesse, 'Patriotic Welfare in Otago,' 63.

${ }^{69}$ Wealthy businessmen, importers, manufacturers or managing directors of companies on the OGWPA executive included Robert Glendining, John Ross, George R. Ritchie, Charles Speight, William Dawson, James Armour Johnstone, Percy Rolfe Sargood, David E. Theomin, George Joachim, John Roberts, Thomas Sandilands Somerville, Thomas Whitelock Kempthorne, James Gray, Donald Reid, John McNair Mitchell, Charles William Rattray, William Fraser Edmond, Edgar Christopher Hazlett, Alexander Burt, William Thomas Talboys, Thomas Fergus, George Lyon Denniston. Newspaper men included Mark Cohen of Dunedin's Evening Star, George Fenwick and James Hutchison, both of the Otago Daily Times and Otago Witness. Lawyers John McRae Gallaway, John Fraser McQueen Fraser, Saul Solomon, Robert Gilkison, and Alexander Bathgate were also members as well as a judge, Justice William Alexander Sim, and a doctor, Dr Robert Valpy Fulton. For the similiar domination of patriotic societies by the elite in Christchurch, see Parsons, 'Debating the War,' 552-553. 
philanthropy, voluntary societies, churches and religious organisations or local or national politics, and included William Downie Stewart who was voted head of the association's finance subcommittee. ${ }^{70}$

Involvement in public life was part and parcel of middle- and upper-class male identity. As noted above, women's relationship to public duties was more complicated. In relation to the female committee of the OSWPA, these women's most obvious entry point into public life lay in kin relationships with prominent men. A significant proportion of the OSWPA's leadership were the wives or daughters (or, in Mary's case, sisters) of men who served on the committee of the OGPWA. ${ }^{71}$ However, the importance of philanthropy to the identity of middle and upper class women in this period should not be understated. As noted earlier in this chapter, the imperative on women to 'serve' was not new, but part of a middle-class language of duty that predated the war. As Lewis has put it in the English context, '[middle-class] women's call to serve others was inspired by their perception of "duty" and was perceived to constitute their main obligation as citizens, ${ }^{72}$ In New Zealand, the women of the Stewart family clearly regarded voluntary service as a superior vocation. ${ }^{73}$ As Rachel wrote in a 1909 letter discussing her sister Mary's plans to train either as a professional nurse or as a Plunket volunteer, 'As a voluntary worker she will have a freer hand \& I think a greater sphere of usefulness than as a paid worker... ${ }^{74}$ The majority of the women who comprised the OSWPA's founding committee had, by the time of joining the Association, already accumulated experience working for social or religious causes. Their existing philanthropic interests adhered to the main social concerns of wealthy urban women involved in public life in this period, summarised by McAloon as 'the domestic arts, the

\footnotetext{
${ }^{70}$ For the involvement of the Otago and Canterbury wealthy in public life see McAloon, No Idle Rich, chapter seven.

71 These included Mrs Lucy Sargood (married to businessman Percy Sargood), Miss Jean Burt (daughter of Alexander Burt, founder of A \& T Burt Ltd), Miss Mary Ross (daughter of Sir John Ross, importer and manufacturer), Mrs Marie Theomin (wife of David Theomin, importer), Mrs Margaret Johnstone (wife of James Armour Johnstone, managing director of Wright Stephenson), Mrs Louisa Roberts (wife of wool exporter and pastoralist John Roberts), Mrs Greta Ritchie (wife of George Ritchie, managing director of an insurance company) Mrs Jeannie Gray (married to James Gray, manufacturer), Mrs Lily Fulton (wife of Dr Fulton), Mrs Frances Mary Sim (married to Justice William Sim), Mrs Alice Gallaway (wife of lawyer John McRae Gallaway). Jane Runciman was one exception to this rule of qualification by connection to well-known men: Runciman was of a working class background but had accumulated significant experience working for unionist and social causes before the war. Melanie Nolan, 'Runciman, Jane Elizabeth - Biography,' DNZB, updated 2-May-12, URL:_http://www.TeAra.govt.nz/en/biographies/3r33/ runciman-jane-elizabeth, accessed 2 May 2013. A further fifteen women joined the OSWPA's executive between October 1915 and 1919 as representatives of suburban and regional branches.

${ }^{72}$ Lewis, Women and Social Action, 11.

73 One possible reason for this is that working for income was believed to detract from the ideals of duty that such middle-class women subscribed to. Prochaska, Women and Philanthropy, 6.

74 Rachel to Mrs B. Collie, 24 October 1909, MB-391-1/2, MBL.
} 
health and early education of children, hospital work, prohibition, and imperial glory. ${ }^{75}$ Thus, the OSWPA's executive included members or former members of the imperialist organisations the Victoria and Navy Leagues, women with previous experience working for infant and maternal welfare, and members of hospital visiting guilds. ${ }^{76}$

The wartime activities of the OSWPA thus represented, to a great extent, a rediversion of the energies of existing women's philanthropic organisations into a new cause. Some existing organisations were simply subsumed into the new organisation. As an example of this strategy, the Otago branch of the Victoria League had, by 1916, discontinued its work as a separate organisation and 'thrown in its lot' with the OSWPA. ${ }^{77}$ Other existing organisations expanded their pre-war work by adding patriotic causes to their lists of beneficiaries (sometimes at the expense of existing causes). The Dunedin Hospital Guild, which had held monthly sewing meetings for the benefit of hospital patients since its foundation in 1902, added to its remit donations of sewing work for military hospitals, via the Red Cross. ${ }^{78}$ Similarly the Plunket Society extended its existing interest in infant welfare by sending 'cases of baby clothing' to England in conjunction with the OSWPA. ${ }^{79}$ Others, such as the Red Cross and Overseas Club, maintained their own distinct identities but cooperated with the OSWPA on specific projects. ${ }^{80}$

Like the female imperialist organisations described in British historian Julia Bush's work, women's patriotic groups gravitated towards work that was 'personal' or 'practical' in nature. ${ }^{81}$ 'Personal' here referred to work that involved one-to-one contact, while 'practical' conveyed the sense of being 'small-scale', 'down-to-earth' and useful. ${ }^{82}$ The 'personal' aspects of the Association's activities included its hospitality work: such

\footnotetext{
75 McAloon, No Idle Rich, 164.

76 OSWPA executive members Jean Burt, Greta Ritchie, Frances Sim, Marie Theomin, Mrs E. C. Reynolds, Mrs Lucy Sargood were all current or former office-holders of the local branch of the Victoria League, while Marie Theomin headed the Dunedin women's branch of the Navy League. For the Victoria League in New Zealand, see Katie Pickles 'A Link in "The Great Chain of Empire Friendship": the Victoria League in New Zealand,' The Journal of Imperial and Commonwealth History 33, no. 1 (January 2005): 29-50. Marie Theomin also was a founding member and one-time secretary of the Plunket society (the Society for the Promotion of the Health of Women and Children), while Margaret Johnstone and Mrs Gallaway were committee members of the same society. Jane Runciman was a member of the Dunedin branch of the New Zealand Society for the Protection of Women and Children. Mary Downie Stewart and fellow OSWPA committee member Mrs McGeorge served on the committee of the Hospital Saturday Association, while Rosalind Nevill was involved with the Dunedin Hospital Guild.

77 'Victoria League,' Otago Daily Times, 25 May 1916, 2.

78 'Dunedin Hospital Guild,' Otago Daily Times, 18 December 1915, 3.

79 'British Soldiers' and Sailors' Babies,' Otago Daily Times, 25 June 1919, 8.

80 OSWPA Minutes, 5 October 1915, AG-73, OSM.

${ }^{81}$ Bush, Edwardian Ladies and Imperial Power, 74.

82 Ibid.
} 
as hosting the regular entertainments for departing troops at which Mary delivered many of her wartime speeches. In addition, the OSWPA hosted welcome home parties for returning soldiers, planned social functions for the families of soldiers serving overseas, visited soldiers hospitalised in Dunedin and looked after the upkeep of soldiers' graves in Dunedin city cemeteries. ${ }^{83}$ The Association's fundraising initiatives combined the personal and practical. Members of the committee staffed refreshment stalls selling items such as home baking, collected donations on the streets and organised garden fetes and flower days to raise funds. The OSWPA's practical work commenced with the sewing, assembling and packing of soldiers' kits and outfits for the first contingent of Otago troops. From 1915, after the military assumed responsibility for providing troops with full outfits and kits, the Association diversified its practical contributions to the war effort considerably. ${ }^{84}$ But probably the most significant branch of the OSWPA's practical work was in its funding and production of the parcels of food and clothing items known as soldier 'comforts'. These form the main subject of the remainder of this chapter.

The Early Settlers Hall, adjacent to the Dunedin Railway Station in the centre of the city, became the base of the OSWPA's wartime activities and the headquarters of its executive. The Early Settlers' Association offered the OSWPA use of its hall free of charge early in the war, and it was rapidly transformed into a site of production for patriotic goods. Throughout the war the hall represented one of the most visible sites of women's patriotic labour in the city. An Evening Star journalist who visited the Hall in August 1914 described the OSWPA's workroom as a 'splendid scene' and its female workforce as 'as grimly in earnest as are the men who are to fire the guns' ${ }^{85}$ However, the Hall's most important function was as a reception and distribution point for incoming goods produced by individuals and goods from all over the Otago and Southland region.

The OSWPA shipped an impressive number of articles from its Hall during the war. By 7 November 1914, less than three months after its formation, it had already issued 1600 full kits containing 33,600 articles of clothing to Otago and Southland

\footnotetext{
83 OSWPA minutes, 8 September 1914, AG-73, OSM.

${ }^{84}$ OSWPA Record Book, AG-73, OSM.

85 'Dunedin Women's Association,' Evening Star, 20 August 1914, in OSWPA Scrapbook Album, AG-73, OSM.
} 
soldiers. $^{86}$ Between August 1914 and September 1918, the OSWPA supplied 233,899 articles to Otago and Southland men on troopships as part of the parcels known as 'transport gifts'. ${ }^{87}$ It also cooperated with other provincially-based women's organisations in the national Dominion Gift Parcels scheme, organised under the auspices of the Governor General's wife Lady Annette Liverpool. This scheme aimed to send a parcel per month to each New Zealand soldier serving abroad. From June 1916 when the OSWPA contributed its first monthly quota of Dominion Parcels - to March 1919, the OSWPA packed and forwarded 184,103 Dominion Parcels. ${ }^{88}$ Disputes emerged among the various provincial patriotic organisations, however, over who should be the chief beneficiaries of each district's patriotic labour. In November 1916, Mary Downie Stewart received a letter from Jessie Gunson of the Auckland Provincial Patriotic League objecting to the OSWPA's practice of sending its transport gifts solely to Otago and Southland soldiers. This, according to Gunson, contravened an earlier agreement between the four main women's patriotic organisations to pool their efforts to supply gifts to every New Zealand soldier: 'I was rather sorry to see that you are sending your transport gifts...to "Otago" men as thereby you depart from the principle of general distribution, to which we all so strongly adhere. ${ }^{89}$ Mary's pencilled reply on the same letter indicated that her organisation had no intention of altering its original practice of sending its transport gifts only to Otago and Southland men.

From July 1915, OSWPA also supplied shipments of hospital clothing to New Zealand soldiers convalescing in military hospitals overseas. ${ }^{90}$ In addition, the OSWPA contributed donations of goods, clothing and money to an array of local, national, and mainly British-based overseas war funds and charities. ${ }^{91}$ Further afield, the OSWPA formed a point of liaison with overseas networks of New Zealand volunteers such as the London-based New Zealand War Contingent Association, which was a significant distributor for goods received from New Zealand-based organisations such as the OSWPA. Its activities are discussed more fully in chapter two of this thesis.

\footnotetext{
86 In 1914, the contents of a kit included 2 shirts, 1 woven belt, 1 housewife, 2 handkerchiefs, 1 muffler or chestprotector, 1 set of cuffs, 1 service bag, 1 balaclava, 1 Holdall, 1 cardigan, 2 towels, 2 singlets, 2 pairs of underpants, 2 pairs of socks and 1 pair braces. OSWPA Record Book, AG-73, OSM.

87 Ibid.

88 Ibid. In November 1916 a 'Dominion Parcel' contained 'Coffee, meat, milk, paper, and a bag; or dates, milk, meat, writing-pad and pencil, and a bag'. 'Women's Patriotic Association,' Otago Witness, 15 November 1916, 41.

89 Jessie Gunson to Mary, 29 November 1916, MS-0985-053/001, HL.

90 OSWPA Record Book, AG-73, OSM.

91 These included Lady French appeal (clothes for British babies), Belgian Relief Fund, Princess Mary's Sailors' and Soldiers' Christmas Fund, Wounded Soldiers' Fund, Baby Week Fund, Christmas Box Fund, Tobacco Fund, Wellington Soldiers' Club, and the Lady Liverpool and Mrs Pomare Maori Fund.
} 
Preparing and packing tens of thousands of parcels each month and organising their delivery to New Zealand soldiers on the frontlines represented a formidable logistical exercise. Organisations such as the OSWPA took seriously the task of planning the contents of their parcels so as to best cater for the needs of troops. The OSWPA leadership actively solicited feedback from the soldiers who received its parcels, and from their own contacts near the front. An OSWPA report of June 1918 noted that a tin of Highlander Condensed milk was included in each of its parcels, as based on 'thousands of letters and cards received from the trenches', its leadership had concluded that 'a tin of milk is the most valuable gift we can send. ${ }^{92}$ Such exchanges of information between civilian patriotic organisations and soldiers at the front contradicted the assumption that homefront populations knew little or nothing of the conditions that soldiers experienced. In addition, some soldiers' graphic descriptions of the conditions surrounding their parcel's opening, sent as part of acknowledgements to the parcel's sender, suggested that soldiers did not always spare civilians from descriptions of the horrors of the trenches. Tapanui man Thomas Falconer reported receiving a 'welcome parcel from home' which he had enjoyed ' $30 \mathrm{ft}$ under ground'. But he also recounted a near miss from a shell and the battlefield scene presented by the first day of the Somme: 'it was a terrible sight to see the dead and wounded, some of the latter being mutilated'. ${ }^{93}$

The friendship and kin networks of the upper-class leaders of women's patriotic organisations proved advantageous in sourcing information on soldiers' needs. Both Mary and Rachel took advantage of their sister-in-law Elizabeth's military connections and presence near the front to seek advice on appropriate gifts for soldiers. In September 1915, Elizabeth and her sister Agnes interviewed Colonel Charters, commander of the New Zealand base in Egypt, on the subject of soldier parcels. After relaying an account of their meeting, Elizabeth added, 'Ask me anything you want to know \& if I can find out about it, I will'. ${ }^{94}$ Similarly, while in Marseilles, Elizabeth consulted with a Mr Henderson, in charge of the Australian Comforts Fund Base Depot, on suitable contents for soldier parcels. She duly conveyed his response back to her sisters-in-law: 'Sporting matriel [sic] of all kinds, Tined [sic] fruits - sweets of all

\footnotetext{
92 ‘Otago Women's Association,' Otago Daily Times, 8 June 1918, 7, in OSWPA Scrapbook, AG-73, OSM.

93 'In the Trenches,' Tapanui Courier, 29 November 1916.

${ }^{94}$ Elizabeth to Rachel, 11 September 1915, MS-0985-041/001, HL.
} 
kinds - Smoking material, including pipes - Sox - singlets \& underpants - cocoa \& waterproof clothing $\&$ head wear - (these are in the order in which the demand is most felt). ${ }^{95}$
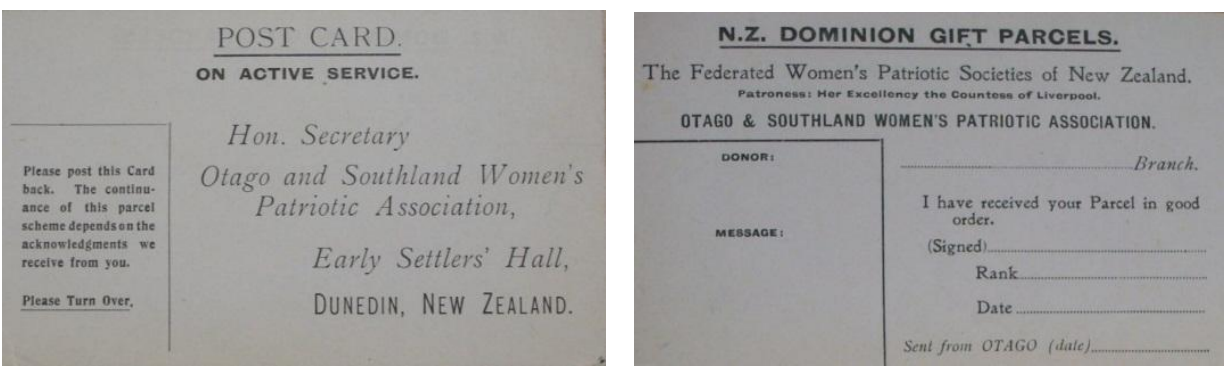

Figure 1.3: N.Z. Dominion Gift Parcels post card

Source: Series 5, AG-73, OSM.

\section{Patriotic organisation membership}

Descriptions of women's patriotic work were frequently accompanied by claims that women's participation in such work was virtually universal. 'I suppose there is hardly a woman in the country who has not had some share in outfitting the Expeditionary Force', the editor of the Otago Witness's 'Ladies Page' mused in September $1914 .{ }^{96}$ Such claims certainly contained an element of hyperbole. Some accounts of women's supposedly universal participation in war work were clearly intended to underscore the perceived failure of some men to perform their patriotic duty of volunteering. An Oamaru Mail journalist, who interviewed Mary Downie Stewart and OSWPA secretary Jean Burt in November 1916 concluded his article with the statement that: 'The most flawless gem in New Zealand's crown to-day is the work of the women. Elsewhere you may find sordid motive, or selfish aim. With them you find only the pure and unselfish devotion... Some of our men may fail us. Our women never will'. ${ }^{97}$ While claims as to women's universal participation may be exaggerated, the sheer number of items shipped out of the Early Settlers' Hall during the war belies any suggestion that support for the OSWPA's patriotic activities was confined to the three dozen or so women who made up the organisation's leadership. ${ }^{98}$

\footnotetext{
${ }^{95}$ Elizabeth to Rachel and Mary, 17 June 1916, MS-0985-041/002, HL.

96 'The Week,' Otago Witness, 9 September 1914, 63.

97 'Typical Topics,' Oamaru Mail, 22 November 1916, 1, in OSWPA Scrapbook Album, AG-73, OSM.

98 Australian historian Bruce Scates also found patriotic war work to be a 'socially diverse' and 'ultimately quite inclusive' movement. Scates, 'The Unknown Sock Knitter,' 35.
} 
The Association bypassed the difficulties of defining its membership by simply declaring 'every woman in Otago and Southland' a member of its organisation. ${ }^{99}$ But the identity of the OSWPA's 66 affiliated branches gives some clues as to the nature of its active membership. The majority, 57 branches, represented suburban areas or country districts. ${ }^{100}$ The leadership of other large urban women's patriotic organisations clearly recognised the value of cultivating support in the regions. In July 1916, for example, Mrs Jessie Helen Gunson and Miss Spedding 'the leading spirits in the Auckland Women's Patriotic League' were 'away organising the country districts' and were 'everywhere receiving cordial welcomes. ${ }^{101}$ By the end of a fortnight's tour of the Bay of Plenty by the two women in November the same year, as Gunson informed Mary, their organisation had 86 branches and was in touch with practically the whole of our military area'. ${ }^{102}$ Mary embarked upon a similar branch-building tour in 1916, when she travelled to Clinton, Invercargill and Gore and other Southland centres 'speaking on our patriotic work. ${ }^{103}$

By far the most significant site of production of soldier comforts was the home. An early description of the work to equip the first contingent of Otago troops with kits reported that 'more than one drawing room was transformed for the time being into a clothing factory working with a cheerful disregard of labour laws that was enough to turn a whole department grey'. ${ }^{104}$ Patriotic sewing groups often met in members' homes. ${ }^{105}$ The Kaihiku branch of the Red Cross met at the home of one of its members, Mrs Head, each week, while others 'unable to take an active part' donated goods they had made at home. ${ }^{106}$ The Waikaia branch of the Red Cross installed two bandagemaking machines at 'the residence of T. Sterling', where its six members met regularly to sew and kept the machines 'very busy'. ${ }^{107}$

\footnotetext{
99 'Women's Patriotic Association,' Otago Daily Times, 26 August 1916, 11, in MS-0985-053/001, HL. 100 OSWPA Branch Lists, AG-73, OSM. The Otago and Southland Red Cross was also dispersed across a wide geographical region, with three sub-centres and 123 branches in operation across the two provinces by December 1916. 'The Red Cross Society,' Otago Witness, 6 December 1916, 60.

101 'Table Talk,' Otago Witness, 2 August 1916, 58-59.

102 Jessie Gunson to Mary, 29 November 1916, MS-0985-053/001, HL.

103 Mary to Rachel, c. 1916, MS-0985-040/003, HL.

104 'The Week,' Otago Witness, 19 August 1914, 63.

105 Scates argues that such groups formed potential 'communities of mourners' united by shared experience of bereavement or by fears for loved ones overseas. Scates, 'The Unknown Sock Knitter', 39-40. For the links between women's war work and grief see chapter three of this thesis.

106 'Kaihiku,' Otago Witness, 22 December 1915, 31.

107 'Waikaia,' Otago Witness, 2 August 1916, 27.
} 
Home production transformed women's ordinary domestic tasks into acts of patriotic service, while allowing women to contribute to the war effort without compromising their responsibilities to their families. Tasks such as sewing or jammaking for parcels capitalised on practical domestic skills and talents which were part of the repertoire of most housewives in this period, and which could be undertaken in private homes and fitted around other domestic duties, such as minding children. ${ }^{108} \mathrm{In}$ soliciting supplies for its soldier parcels, the OSWPA emphasised that the work could be incorporated into a housewife's ordinary routines. In December 1915, the Association circulated a letter to its branches asking members to set aside jam for soldiers when making their year's supply. 'We are having tins made costing about $2 \mathrm{~d}$ each [dozen], and we hope that most women will take a dozen or more of these tins to fill when they are making their own jam for the year...We understand that nothing is more appreciated by the men than good, fresh jam'. ${ }^{109}$ Forty eight out of the OSWPA's 56 branches were self-supporting, meaning that they organised their own fundraising to raise money for parcel materials or for other patriotic causes of their choice. ${ }^{110}$ Common fundraising methods such as gift stalls and jumble sales also capitalised upon women's existing practical or domestic skills, such as sweet-making, baking or flower arrangement, or utilised outputs of domestic production such as eggs. At Heriot, West Otago, the sixteen members of the local branch of the OSWPA raised funds for materials by establishing a tearoom to sell baking contributed by members, as well as canvassing local women for donations. ${ }^{11}$

The efforts of women's organisations such as the OSWPA to equip Otago or New Zealand troops with comforts were matched by those of individuals and families sending parcels addressed to particular soldiers. Postal service records point to an exponential growth in the numbers of this type of parcel sent over the war years. ${ }^{112}$ In 1915, the first year in which parcels sent to members of the NZEF were enumerated

\footnotetext{
108 According to the authors of Sites of Gender, 'most housewives also contributed substantially to the family's income through various forms of self-provisioning - making jams and preserves, sewing and knitting, and so on'. Annabel Cooper, Erik Olssen, Kristen Thomlinson and Robin Law, 'The Landscape of Gender Politics: Place, People and Two Mobilisations', in Brookes, Cooper and Law, eds., Sites of Gender, 23. Many of the interviewees for Claire Toynbee's study of gender and work, the majority of whom were born before 1912, recalled their mothers sewing or mending garments in spare moments. Toynbee, Her Work and His, 65.

109 'Otago Women's Association,' Otago Witness, 8 December 1915, 51.

110 OSWPA Branch Lists, AG-73, OSM.

111 'Heriot,' Tapanui Courier, 19 December 1917; 'Heriot,' Tapanui Courier, 16 June 1915.

112 Individually addressed parcels can be distinguished from the bulk parcels sent by the OSWPA and other organisations by the method of shipment used. Organisations like the OSWPA arranged shipping for their parcels in bulk on military transports or hospital ships, while parcels addressed to individual soldiers travelled through the postal service.
} 
separately, the Postal Service despatched 60,214 parcels to NZEF members overseas. By the end of 1916, the numbers of parcels posted had reached 251,164. ${ }^{113}$ For 1917 and 1918, the total number of parcels leaving New Zealand for members of the Expeditionary Force were 392,235 and 442,318 respectively. ${ }^{114}$ As well as forwarding the outputs of their patriotic work to the Early Settlers Hall for distribution by the OSWPA, many local groups opted to devote part of their energies to preparing goods for the benefit of local soldiers. In June 1915, the Tapanui OSWPA branch forwarded 45 pairs of socks made by 'Tapanui District Ladies' directly to 'local men at the front'. ${ }^{115}$ In June 1916, the same branch announced a scheme to supply every Tapanui man at the front with a monthly parcel. The Tapanui Courier recorded: 'They are anxious to supply at least 10 parcels monthly, and will be grateful of donations of produce to be sold in aid of the fund, cash, or a promise of one or more parcels monthly' ${ }^{116}$

Whether they were intended for specific individuals, local men, or anonymous soldiers, those who prepared soldier comforts did so with a range of practical and emotional benefits in mind. OSWPA publicity frequently highlighted the usefulness of its parcels, which it regarded as essential to maintaining the army's military strength and morale. As food shortages in Europe worsened later in the war, the importance of sending food to supplement frontline soldiers' diets formed a growing part of publicity for the Dominion Parcels scheme. A May 1917 article promoting the scheme noted that 'Owing to the shortage of foodstuffs at Home the parcels are mainly devoted to a supply of eatables and comprise, among other things such articles as condensed milk, tinned meat, sugar, jam, sweets, etc'. ${ }^{117}$ As a handwritten note on the OSWPA's work preserved in Mary's personal papers suggests, its leadership considered their work in supplying clothing as vital to maintaining the fighting efficiency of the army. Describing her Association's efforts to equip soldiers with clothing as 'one of the most important branches of our work', Mary added 'we feel it is absolutely essential that a man is well equipped. For instance socks are of the utmost importance, a badly fitting sock may mean a blistered foot which would force a man to fall behind in the march'. ${ }^{118}$ Parcels also fulfilled basic domestic functions by providing sustenance in the form of food

\footnotetext{
113 Annual Report of the Postal and Telegraph Department, Appendices to the Journals of the House of Representatives (AJHR), 1916, F-1, 31. It is unclear whether the 1915 figure represents the whole or part of the year.

114 Annual Report of the Postal and Telegraph Department, AJHR, 1919, F-1, 43.

115 'Socks For Troops,' Tapanui Courier, 2 June 1915.

116 'Dominion Gift Fund,' Tapanui Courier, 14 June 1916.

117 'Picture Week,' Otago Daily Times, 17 May 1917, 9, in OSWPA Scrapbook, AG-73, OSM.

118 Mary Downie Stewart, handwritten notes, MS-0985-053/002, HL.
} 
items or supplying clothing to protect men from the elements. Unlike families closer to the front who were able to send fresh foods to supplement front-line soldiers' diets, New Zealand families and patriotic groups were confined to sending non-perishables. Nevertheless, the inclusion of canned, dried or preserved foods in parcels fulfilled the same basic 'motherly' functions of providing nourishment, or supplying favourite foods. ${ }^{119}$

Parcels sent to individual soldiers by their families at home served to sustain existing family ties in a range of ways. The sending of parcels helped to maintain intimate relationships across geographic distance, as did the letters or notes frequently enclosed within them. But even those who sent parcels to anonymous individuals believed that their efforts helped foster connections between home and front. An Otago Daily Times article describing women's patriotic work claimed that 'the greatest reward the workers can receive...is the many letters sent by the men from all over the world, thanking them, telling them of their experiences at the front, stating that the parcels bring back longing thoughts of home, asking the ladies of the association to write to them'. ${ }^{120}$ Even when the recipient of their parcel remained anonymous, the leadership of women's patriotic organisations frequently chose to frame their objectives using familial imagery. Material promoting the OSWPA's work frequently described the donors of parcels as 'soldiers' mothers'. Describing the work of the Association in the Early Settlers Hall in September 1914, the Otago Witness identified its workers as 'mothers' to the men who received the parcels: 'It needs no stretch of the imagination to realise the tenderness with which each woman equipped every kit with articles intended to minister to the comfort of the recipient', such kits which, the article went on, might be 'destined for the creature comfort of her "bairn", or if not hers, then some other woman's "bairn"". ${ }^{121}$ The OSPWA was not unique in this respect: other wartime organisations with significant female memberships also described their work in quasi-familial terms that collapsed the distances between home and front. The New Zealand Red Cross, for instance, described itself as the 'The GREATEST MOTHER in the WORLD'...

119 Parcels shipped through the British Expeditionary Force, by contrast, usually arrived at the front within four days of postage, allowing the shipping of fresh produce. Rachel Duffett, The Stomach for Fighting: Food and the Soldiers of the Great War (Manchester: Manchester University Press, 2012), 192.

120 'God Bless You, Little Lady,' Otago Daily Times, 7 November 1917, 8, in OSWPA Scrapbook Album, AG-73, OSM.

121 'The Week,' Otago Witness, 23 September 1914, 43. 
Reaching out her hands to No Man's Land; warming, feeding, and healing thousands of suffering men. ${ }^{122}$

Conversely, while in describing its own work in quasi-familial terms, the OSWPA's publicity work for its various parcels schemes also drew attention to the failings of actual families. The figure of the 'lonely soldier' - a man who either lacked a family or whose own family was somehow deficient in sending parcels - emerged early in the war as a way of manipulating public sympathies to solicit donations. For instance, in a speech to the members of the Mornington Sewing Guild, Mary told her audience to envisage the beneficiaries of their work as 'lonely soldiers':

I know that many of you have sons \& perhaps brothers \& husbands at the front, \& you naturally are sending parcels to them; but we know that there are many lonely soldiers who have no one specially interested in them - Think what it must mean to those poor fellows - when the mail comes in \& they see time after time - their comrades getting letters \& parcels - getting inspiration to give them fresh heart $\&$ fresh hope, \& think of the utter weariness of heart that they must endure, no letters, no parcels, nothing to encourage, nothing to assure them of our womens' gratitude. ${ }^{123}$

The 'lonely soldier' appeared in the OSWPA's publicity as early as December 1914. In that month, an account of the Association's work claimed that, in stocking clothing for returned soldiers, the association hoped 'to stand by any forlorn soldier who, on returning, has neither mother nor sister to keep him'. ${ }^{124}$ The same idea had also pervaded public consciouness, as evidenced by one Waikouaiti woman who prepared 'Xmas parcels' for her son and the son of a friend and then contacted Mary Downie Stewart to enquire if her Association would send them free of charge: 'Someone said you would forward them for us for free. I can hardly think that unless the parcels are for lonely boys \& not particular men'. ${ }^{125}$

But despite the ubiquity of the lonely soldier in their publicity, patriotic organisations had trouble identifying actual lonely soldiers. When, in May 1915, Kelso

122 The New Zealand Red Cross Record, April to May 1919, 11, cited in Boston, "The Bacillus of Work," 47.

${ }^{123}$ Mary Downie Stewart, speech to Mornington women, n.d., MS-0985-053/007, HL.

124 'Loyal Women of Otago', Evening Star, 30 December 1915, in OSWPA Album and Scrapbook, AG-73, OSM.

125 (name illegible) to Mary, 12 October 1915, MS-0985-053/002, HL. 
woman G. Lamborn wrote to the OPGWA asking for 'the name \& address of a Friendless Soldier' to whom 'I would only be too glad to be of a little Service', the Society replied that it had nothing of the requirements in the direction mentioned by you' ${ }^{126}$ The straitened financial circumstances of some families during the war offer a plausible explanation for why some soldiers did not receive parcels, however. As is further explored in chapter five, wartime mobilisation placed significant financial burdens upon families which, in some cases, would have placed the sending of regular parcels beyond their means. While it did not alter its publicity, the OSWPA did acknowledge the difficult financial circumstances faced by some families by introducing a scheme to ship individually addressed parcels free of charge. In May 1915, the OSWPA appointed a sub-committee to deal with the "forwarding of private parcels to Egypt', while later that year, its parent organisation the OPGWA made provision for the forwarding of thousands of individually addressed parcels for Otago men in time for Christmas $1915 .{ }^{127}$ But the OSWPA's scheme had already ceased by December 1915, when it issued a notice that 'Some people continue to send in parcels to the Early Settlers' Hall for forwarding to their soldier friends at the front. The association wishes to state that it has no immediate facilities for sending these on. ${ }^{, 128}$

The belief that parcels served an essential emotional function in forging connections between frontline soldiers and New Zealand homes also entered into the OSWPA's logistical planning. Mary Downie Stewart informed the men of the departing $19^{\text {th }}$ reinforcements that they could expect to receive their parcel of comforts from 'the Women \& the Schoolchildren of Otago \& Southland' near the end of their voyage on the troopship: 'We do not give our presents to you just now, because we feel they will mean more to you after you leave N.Z. When you get the parcels, I ask you to accept them as a small remembrance of home'. ${ }^{29}$ At least some soldiers appear to have viewed their parcels in similar terms. 'One of the boys', writing from Salisbury military camp, England, in November 1916 to thank 'the ladies of Otago and Southland for their very useful gifts' stated: 'If you only knew how useful they were and how they made us think of home! I think every man valued his more than a five pound note at the time'. ${ }^{130}$

126 'Correspondence, 1914-1915,' Otago Provincial Patriotic Council Records, AG-113/249, HL.

127 OSWPA Minutes, 7 May 1915, AG-73, OSM; J. J. Clark to B. Spedding, c. November 1915, AG-113/210, HL; J. J. Clark to J. E. Watson, Dunedin, c. October 1915, AG-113/210, HL.

128 'Otago Women's Patriotic Association,' Otago Witness, 22 December 1915, 52-53.

${ }_{129}$ Mary Downie Stewart, speech to $19^{\text {th }}$ reinforcement, c. November 1916, MS-0985-053/007, HL.

130 OSWPA Scrapbook Album, AG-73, OSM. 
While government eventually assumed full responsibility for equipping its armed forces with uniforms and kits, the OSWPA maintained control over the production of parcels for the duration of the war, and strenuously resisted any proposals that their organisation should be passed over to government or the military. When, in 1917, the Auckland League announced its intention to withdraw from the Dominion Parcels scheme and to instead forward donations to officers to purchase comforts overseas, the OSWPA voiced its objections. ${ }^{131}$ The OSWPA's opposition to Auckland's plans rested partly on the grounds that wartime shortages would limit soldiers' choice of purchases. But the Association also feared that the emotional value of gifts sent from home would thereby be lost. 'The sentimental aspect of the gift parcels should also not be overlooked. They are veritable messages from home, these parcels. The many letters received here show how they are appreciated, and how the little messages which go with them are treasured'. ${ }^{132}$ Mary Downie Stewart and secretary Jean Burt also objected, upon similar grounds, to suggestions that governments take over the work of organising parcels. As they informed an Oamaru Mail journalist in November 1916: 'No matter what the Government might do it could never supply that human touch, that sense of love and interest which accompanies all things we send to the boys. They appreciate the woman's touch, and surely we all want them to feel that no matter where they are the love of their own womanfolk at home here follows them through all their experiences. ${ }^{133}$ As the comments of Mary and Burt make clear, the role of surrogate kinship for soldiers overseas could only be fulfilled by female volunteers from a soldier's own country, or even more preferably, own district or community. Comforts arranged by government nor the military could not fulfil the same practical and emotional functions as parcels sent by the womenfolk of New Zealand.

\section{Conclusion.}

The title quote of this chapter, 'Each Battling in their Respective Spheres' evokes an image of the war as a shared endeavour between men and women, in which each sex was engaged in different, yet equal and complementary spheres of action: both 'battling' towards a common objective. This encapsulates the vision of the war promoted by the Stewart family and other members of their influential circles. All four Stewart siblings supported the war effort and responded to what they believed to be a higher call to their

\footnotetext{
131 The Auckland League suggested this change after receiving complaints surrounding the uneven distribution of parcels. 'Dominion Gift Scheme,' Otago Daily Times, 8 June 1917, 7, in OSWPA Scrapbook, AG-73, OSM.

132 'Dominion Gift Scheme,' Otago Daily Times, 8 June 1917, 7, in OSWPA Scrapbook, AG-73, OSM.

133 'Typical Topics,' Oamaru Mail, 22 November 1916, 1, in OSWPA Scrapbook, AG-73, OSM.
} 
wartime duty. For members of the upper classes, moral leadership required public performance, and the best type of leadership was that by example. While the course of action was relatively clear for William, a single and able-bodied man, public performance entailed greater contradictions for prominent women like Mary Downie Stewart, charged with projecting outwards the feminine virtues associated with family life and the home. But, as the chapter also argued, belief in the essential differences between men and women, when translated into organisational practices and ideology, provided the leadership of women's patriotic organisations with a justification for their separate existence. In framing their work as bridging the distances of home and front through acting as surrogate family to soldiers overseas, the leadership of women's organisations argued that their efforts met essential needs and represented an aspect of the war effort that could only be carried out by soldiers' families - or female volunteers acting on their behalf. Women's sense of duty, as the next chapter demonstrates, could also take them overseas: to Egypt, the United Kingdom and other locations in closer proximity to the battlefronts than New Zealand. 



\section{CHAPTER TWO}

\section{CONNECTING HOME AND FRONT: PATRIOTIC WOMEN TRAVELLERS.}

In the same month that her husband George and brother Alfred Herbert left Wellington on military service, Elizabeth Stewart and her sister Agnes Herbert boarded a passenger ship for Melbourne. There, they joined the ocean liner Medina bound for Egypt, via Colombo. Their purposes for travel were twofold: to be near their soldier relatives and perform 'useful' work for the war effort, so that, as Elizabeth put it 'we will feel that we are doing "our little bit", too'. Arriving at Suez, the sisters took a train to Alexandria where they were met by George, who they described as looking 'thin, but very well \& relieved'. The party proceeded to Ramleh, near Sidi Bishr, where George was encamped, and where the sisters secured hotel rooms. ${ }^{2}$ Between their arrival in July and George's departure for Gallipoli in late August, Elizabeth spent every available moment with her husband - he returning to the hotel at night, she visiting him by day and even accompanying him in his work. During this time Elizabeth relished the opportunities that her proximity to George gave her to share in his experience of the war. She wrote in August 1915: 'On Wednesday George is taking the men for a route march \& we are going too. You can imagine what a joy it is to be able to see so much of our boys \& to be able to do things with them \& know their camp life. ${ }^{3}$ Reflecting upon her decision to go to Egypt, she wrote '[T]hink of how much nicer it will be in the future when George can say "was that the day we went thro" to Cairo"? - or I can remark - "that happened when I was at the front with my husband!' Sidi Bishr Camp is counted the front! ${ }^{4}$

George's death in November 1915 removed the main reason for Elizabeth's presence in Egypt. But, while still on Lemnos awaiting a return passage to Cairo, Elizabeth expressed her desire to continue the war work she and Agnes had begun: 'I will just go on with the work I have started there - one feels one must be doing

\footnotetext{
${ }^{1}$ Elizabeth to Mary and Rachel, 30 June 1915, MS-0985-007/004, HL.

2 Elizabeth to Rachel and Mary, 31 July 1915, MB-391-4/26, MBL.

${ }^{3}$ Elizabeth to Mary and Rachel, 16 August 1915, MS-0985-050/002, HL.

${ }^{4}$ Elizabeth to William, 17 September 1915, MS-0985-007/004, HL.
} 
something these days \& now more than ever I want to help'. ${ }^{5}$ In the following months, the two sisters' movements continued to be dictated by their twin desires to be near soldier relatives and to 'do something' for the war effort. In April 1916, they sailed from Port Said, Egypt, to southern France in the company of five Red Cross workers from the New Zealand military hospital in Cairo. Elizabeth wrote on the eve of their departure: 'We hear we may be able to see something of our boys - that they get four days off every six weeks, or less, in which case they can come to us if they have nothing more interesting to do. - And, between times, we are not afraid of being without useful occupation... it is very wonderful to be going to the very centre of things \& I feel there must be good work for us to do ... I only hope we will be able to give our best whatever calls for our service. ${ }^{6}$

Elizabeth and Agnes shared their experience of wartime mobility with other middle- and upper-class New Zealand women. ${ }^{7}$ Their activities are the subject of this chapter. Some travelled expressly to offer their voluntary services for the war effort abroad - often articulating similar motives of service to those voiced by their middle or upper class male relatives in the armed forces. ${ }^{8}$ Other women travelled primarily to be closer to soldier or officer kin. Through their mobility, some such women managed to personally overcome the prolonged family separations which characterised most New Zealand families' experiences of the war. Such travellers, along with an expatriate community already overseas on the outbreak of war, also formed the core workforce for a series of voluntary institutions established to cater for the welfare of New Zealand troops overseas. Notions of family or fictive kinship were central to the activities and rationale of these institutions. Networks of volunteer visitors sought out news of hospitalised soldiers to convey back to their relatives back in New Zealand, while workers at soldiers' clubs hoped to recreate the sensations of home life for strangers. Such workers' attempts to replicate the moral restraints of home life were revealing of the wider unease with which they and their organisations viewed the all-male

\footnotetext{
${ }^{5}$ Elizabeth to Mary and Rachel, 21 November 1915, MS-0985-041/001, HL. Underlining in original.

${ }^{6}$ Elizabeth to Mary and Rachel, 20 April 1916, MS-0985-041/002, HL.

${ }^{7}$ For this chapter's purposes, a New Zealand woman is counted as any woman who was born in New Zealand and/or spent a significant period of her life domiciled in New Zealand before the war, or who identified herself as a New Zealander.

${ }^{8}$ The focus is on women who offered their services in a voluntary capacity. It excludes the 549 professional nurses who formed part of the New Zealand Army Medical Service, as well as New Zealanders who signed up as nurses or doctors for other country's medical services. Existing studies of New Zealand nurses during the war discuss volunteers in terms of the threat they posed to trained nurses' efforts to gain professional recognition. See Rodgers, “A Paradox of Power and Marginality,"” chapter 9.
} 
communities created by mass military mobilisation. The informal friendship and kinship networks of upper-class women were key to the maintenance of such voluntary organisations and their links to New Zealand-based patriotic groups. In facilitating the flow of news, information, goods and funds between home and front, upper-class networks of female travellers, the chapter argues, were critical in overcoming the boundaries between home and front.

It is now difficult to trace how many New Zealand women like Elizabeth Stewart and Agnes Herbert travelled overseas independently of the organised military effort during the war. Some women's movements are now known to us only through passing mentions in newspaper social pages. In April 1915 the British Australasian, the newspaper of the expatriate Australian and New Zealand community in the United Kingdom, reported that 'Mrs A. E. Chrystall, of Christchurch, who has three sons on active service' was 'in England with her two daughters and intends remaining in this country until the end of the war'. 'Miss Eva Riddle of Wellington, the same newspaper reported, had travelled to England 'to be near her brother who is in the trenches'. While there she took on a job as a driver for a biscuit manufacturing company and hoped to find munitions work at the Woolwich Arsenal. ${ }^{10}$ Social pages exhibit a bias towards the socially prominent, but even the movements of some women within this category escaped attention. The social columns of the British Australasian, for instance, contain no mention of Elizabeth and Agnes' presence in England during the war. Other women travellers are now known to us through the records kept by the institutions at which they volunteered. Such women are only readily identifiable as New Zealanders, however, when they worked at New Zealand institutions. Those New Zealanders who volunteered solely for British, French or other national organisations must be traced through newspapers or other sources. Equally, not all women who volunteered at New Zealand institutions were New Zealanders, and for the purposes of this chapter's analysis, it has been necessary to cross-check these women's national affiliations against details available in their personnel files or elsewhere. ${ }^{11}$

\footnotetext{
9 'Anglo-New Zealand,' The British Australasian, 1 April 1915, 14.

10 'Anglo-New Zealand,' The British Australasian, 31 August 1916, 18.

${ }^{11} \mathrm{New}$ Zealand hospitals frequently employed volunteers from their immediate district, or sought recruits from British voluntary labour exchanges such as Devonport House. Thus, the chapter's analysis includes only those women whose national affiliation was evident from their personnel file or from other sources.
} 
Those New Zealand women travelling to England, and to a lesser extent Egypt, joined an existing expatriate community already overseas on the outbreak of war. Education had formed the motive for some such women's travel. Ethel Burnett, Dorothy Hursthouse and Anna Fell travelled to London together early in 1914 to study kindergarten methods at the National Froebel Union in London. By March 1916, all three had completed their courses, while also finding time for war work. 'Miss Burnett has been working at the "Dugout" Rooms, near the High Commissioner's office, and also at Hornchurch [hospital]... The Misses Hursthouse and Fell have been assisting at [the hospital at] Walton-on-Thames'. ${ }^{12}$ Others - like the artists, musicians and writers who form the focus of historian Angela Woollacott's work on Australian women's travel to London - had moved overseas to further artistic careers. Elizabeth 'Eri' Thomson of Stewart Island was sister to Gladys Herbert nee Thomson, Elizabeth's sister-in-law. ${ }^{13}$ Eri left New Zealand for England around 1909, having been advised by Dame Nellie Melba to complete her studies there 'with a view to taking up vocalism as a profession. Acting on the diva's prompting, Miss Thomson went Home, studied, and for the past eight or nine years she has been on the concert platform in England. The war found the singer ready to do her part, and according to latest advice, Miss Thomson was a VAD worker where she was very popular among the patients'. ${ }^{14}$ Esther Studholme Hope (later Barker) of Waihi, South Canterbury, had travelled to England with her family in 1911, and stayed behind to study art at Chelsea Polytechnic. She was travelling in Brittany with a group of artists when war broke out; she then 'drove lorries and worked as a VAD' before returning to New Zealand in 1919. ${ }^{15}$

One of the primary motivations for women's overseas travel in wartime was the hope that, in the event of a loved one being taken wounded or ill, they might visit them in hospital. Ida Malone, wife of the celebrated Taranaki officer William Malone, sailed to England with her three children and stepdaughter in 1915. As William Malone informed an aunt: 'Her idea is to take a small house in say Reading near which town she has some relatives, and live there quietly, so that in the possible event of any casualty to me or the boys... all of whom will probably be in action before long, she would be near and could

\footnotetext{
12 'Women in Print,' Evening Post, 21 March 1916, 9.

13 Olga Sansom, The Stewart Islanders (Wellington: A.H. \& A. W. Reed, 1970), 85-86. Gladys Herbert was the wife of Elizabeth's brother Jim Herbert.

14 'Personal Items,' Hawera \& Normanby Star, 3 April 1919, 4.

15 Una Platts, Nineteenth Century New Zealand Artists. A Guide \& Handbook (Christchurch: Avon Fine Prints Limited, 1980), 130 .
} 
look after us in England, instead of fretting her soul out in New Zealand'. ${ }^{16}$ While the overwhelming majority of mentions to such travel refer to the arrival of female relatives of soldiers, some fathers travelled to be nearer hospitalised sons. ${ }^{17}$ In October 1916 The British Australasian reported the imminent arrival of ' $\mathrm{Mr} \mathrm{M}$ Morrison...sheep farmer, of Taihape' who was travelling to England to visit his son in military hospital. ${ }^{18}$

The experiences of the Rolleston family of Christchurch, long-time friends of the Stewart family, illustrate the potential advantages to be gained by New Zealand families living in England during the war. Mary Rolleston, the widow of the New Zealand politician William Rolleston, had only recently arrived back in New Zealand with her daughter Helen from a trip to England when war broke out. The pair returned to England soon afterwards, after receiving word that their son and brother John Rolleston had been wounded at Gallipoli. ${ }^{19}$ When Elizabeth Stewart visited the pair in June 1916, they were staying at a 'dear little cottage' Mary had rented just ten minutes away from the New Zealand military hospital at Walton-on-Thames where they saw 'quite a lot of the brother who is in hospital but mending slowly \& very cheerfully! ${ }^{20}$ For most New Zealand families, the receipt of news that a soldier relative had been wounded or taken ill marked the beginning of an agonising wait for information. Families such as the Rollestons had the advantage of being able to assess the condition of their loved one in person, as well as satisfying themselves that he was receiving the best possible care.

Another advantage gained by families who could afford wartime travel was the opportunity to spend time with soldier relatives while on leave or in military camp. By 1917, Elizabeth's sister-in-law Connie, wife to her brother Alf, and their daughter Constance (Girlie) had joined them in England. The army granted Alf leave shortly after his wife's arrival, and the family were reunited in London in April 1917, after nearly two years' separation. ${ }^{21}$ By November 1917, Connie and Girlie were living with family friends in Kent, where Connie enrolled Girlie in kindergarten, creating a space in her

\footnotetext{
${ }^{16}$ The 'boys' William refers to are his sons by his first marriage, Edmond, Terence, Brian and Maurice Malone. In the event, William Malone was killed at Gallipoli in August 1915. John Crawford, ed., No Better Death: The Great War Diaries of William G. Malone (Auckland: Reed Books, 2005), 134, 328.

17 Hunter, 'Australian and New Zealand Fathers and Sons During the Great War,' 189.

18 'Anglo-New Zealand,' The British Australasian, 26 October 1916, 18.

${ }_{19}$ Rosamond Rolleston, William \& Mary Rolleston: An Informal Biography (Wellington A. H. \& A. W. Reed, 1971), 130.

${ }^{20}$ Elizabeth to Mary and Rachel, 17 June 1916, MS-0985-041/002, HL.

21 Elizabeth to Rachel, c. April 1917, MB-391-4/26, MBL.
} 
own day which she hoped to fill 'at either Canteen or Red Cross work'. ${ }^{22}$ The couple spent another of Alf's leaves together on an eight day holiday in Paris in December 1917. ${ }^{23}$ When, in September 1918, Alf was admitted to Brockenhurst with an injured arm Elizabeth wrote: 'Of course Con \& Girlie arrived post haste \& fortunately were able to get a room at the Olde Tea Shoppe with us. So they spend their time \& we see what we can of them all'. ${ }^{24}$ By 1916, a minor tourist industry had arisen at Salisbury, in Wiltshire, to cater for the accommodation needs of relatives visiting New Zealand or Australian soldiers housed at the nearby Sling Camp. Their presence was signalled by an advertisement in the British Australasian which invited 'Australians and New Zealanders who may be going to Salisbury to be near their menfolk in camp' to consider the 'Old George Hotel' for their stay. ${ }^{25}$

While most documented travellers hoped to be closer to male relatives in the armed forces, at least one New Zealand nurse was accompanied in her travels by a family member. Kathleen Davis, a trained nurse in charge of a surgical ward in an Egyptian military hospital reported in 1916 that her mother, who had travelled with her to Egypt, 'goes to the New Zealand hospital and helps with the sewing and looking after the clothes' ${ }^{26}$ Family members also provided travelling companions or chaperones, and it was fairly common for sisters or mother-and-daughter pairs to travel together and serve in the same institutions. ${ }^{27}$ Pairs of friends also travelled and worked together. Minnie Havelaar and Mabel Grigg volunteered at the 'Kia Ora Club', attached to the New Zealand hospital at Brockenhurst, Hampshire, before becoming VAD nurses at the same hospital. Both women then transferred to Oatlands Park, an auxiliary of New Zealand's Walton-on-Thames hospital, before returning to New Zealand together in October $1919 .^{28}$ Travelling in the company of family members or friends freed such

\footnotetext{
22 Elizabeth to Rachel, 27 November 1917, MB-391-4/26, MBL.

${ }^{23}$ Elizabeth to William, 10 December 1917, MS-0985-007/004, HL.

${ }^{24}$ Elizabeth to Rachel, 26 September 1918, MB-391-4/26, MBL. Shortly afterwards the entire family returned to New Zealand permanently after Alf was posted there on a military assignment.

25 'Australians in Europe,' The British Australasian, 22 June 1916, 16.

26 'News From Our Nurses in Egypt', Kai Tiaki, April 1916, 83.

${ }^{27}$ Sisters who worked or travelled together include Ellen and Agatha Dobbie of Auckland; Millicent and Kathleen Laing of Wellington; Edith Inwood and Margaret Latter of Christchurch; Ethel and Frances Lee of Hawke's Bay; Kitty, Marjorie and Winnie Butler of Wellington; Dorothy, Gladys and Phyllis Anderson of Christchurch; Violet and Enid Bell of Wellington; Eileen and Rona Shute of Wellington; Annie and Ellen Stuckey of Masterton and Devon; Selena and Adelaide Collis of Whangarei; Jessie and Margaret Thomson of Southland. Mother-daughter pairs include Mrs R N Fletcher and Miss Margaret Fletcher; Mrs Buckland and Hazel Buckland; Mrs Luxford and Gladys Luxford; Mrs Eileen K Davies and Miss Eileen M. Davies of Auckland. Mrs Duncan Glasgow of Stratford travelled with her two nieces the Misses Hogg.

28 'Minnie G. Havelaar - personnel file,' AABK-22525-W5573-17/37/3947, ANZ. Other instances of friends working or travelling together include Jill Hislop and Laura Salmond; Elsie Booth and Kitty Doughty; Dora Murch
} 
women from the fear that they might be regarded by their fellow passengers as 'not...quite respectable'. ${ }^{29}$

Both advantages and limitations of families' wartime travel are evident in the case of the Ritchie family, friends of the Stewarts. Three of the Dunedin couple John Macfarlane Ritchie and his widow Ella Ritchies' sons: Jim, John (Jock) and Ian, fought for imperial regiments during the war, while Ella and daughter Mary Ritchie also spent the duration of the war in England. ${ }^{30}$ Like Elizabeth and Agnes, the Ritchie women patterned their wartime movements on those of their male relatives. After spending August to October 1915 in Scotland, where Jock was in camp, Ella and Mary Ritchie travelled to London to be with Jim, who had been hospitalised with 'gastritis'. ${ }^{31}$ '[L]ately I have been spending all my free time with Jim at the hospital', Mary Ritchie reported. ${ }^{32}$ In April 1916, the family received an unofficial report that Jock had been killed in action. ${ }^{33}$ Over the next few months, with no official confirmation of his death forthcoming, they clung desperately to the hope that he had somehow survived. Elizabeth visited Mrs Ritchie and Jock's English wife Ellen in late June 1916 and reported to her sister-in-law Mary: 'I told you in my last letter that they had accepted the unofficial statement - that Mr Jock must have been killed - Well, I found them buoyed up again with every hope that he may be a prisoner - on the evidence of another brother officer - How wearing the awful uncertainty must be! ${ }^{34}$ Official confirmation of Jock Ritchie's death finally reached the family in August $1916 .{ }^{35}$ The Ritchies' presence in England potentially opened up more channels of inquiry than would have been available to them had they stayed in New Zealand. But in the end they remained as helpless as more distant families in the face of what Jay Winter terms the 'wartime fog of confusion' that clouded the deaths of so many soldiers. ${ }^{36}$

In other sad cases documented in the Stewart family's correspondence, wives or mothers embarked for England to be nearer soldier kin, only to learn upon arrival of

and Clara Rogers. Sisters Margaret Latter and Edith Mary Inwood also worked and travelled with Margaret Middleton.

${ }^{29}$ Woollacott, To Try Her Fortune in London, 40.

${ }^{30}$ John Macfarlane Ritchie died in 1912. See Jim McAloon, 'Ritchie, John Macfarlane - Biography,' DNZB, updated

15-Jan-2014, URL: http://www.TeAra.govt.nz/en/biographies/2r24/ritchie-john-macfarlane, accessed 23 March 2014.

${ }^{31}$ Mary Ritchie to William, 9 October 1915, MS-0985-003/011, HL.

32 Mary Ritchie to William, 26 January 1916, MS-0985-003/013, HL.

${ }^{33}$ Elizabeth to Mary and Rachel, 17 June 1916, MS-0985-041/002, HL.

${ }^{34}$ Elizabeth to Mary, 28 June 1916, MS-0985-050/002, HL.

35 'Killed in Action,' Otago Witness, 9 August 1916, 21.

36 Winter, Sites of Memory, Sites of Mourning, 30. 
their death. In July 1916 William wrote to Helen Rolleston of the death in action of his friend's brother, Lieutenant George Black. ${ }^{37}$ Black's wife, Dorothy, was at the time of his death on the voyage from New Zealand to England. 'I feel so sorry for poor Black's wife who is due in England in a few weeks \& who was only married a week or two before he left'. ${ }^{38}$ Similarly, Helen Rolleston wrote to William in October of that year that she had been 'terribly grieved' to hear of the death of Christchurch soldier, Jack Bowden. 'His mother is on her way here \& will hear of it at Newport...The thing she greatly feared has come upon her $\&$ it if were not that she has always been so brave over big things while torturing herself over little ones I should be afraid for her mind when she hears. ${ }^{39}$

For other women travellers, the desire to do their bit for the war effort formed a primary reason for their travel. New Zealand woman Catherine Mabel Hislop travelled to England in 1917 to do war work, having received 'a cable that there was plenty to be done'. She took a job as a labourer on a Hertfordshire farm, before becoming a Voluntary Aid Detachment (VAD) nurse. ${ }^{40}$ Another New Zealand woman, Mrs Harriet Simeon, applied to the New Zealand authorities for war work in 1915. Having been 'told there was no opening' she resolved to pay her own passage to England in 1915. Between July 1915 and November 1917 she worked as a VAD nurse for British hospitals in Egypt, Wales and France, before joining the Women's Royal Air Force in February 1918 where she rose to the position of Area Commandant, with '300 officers and between five and six hundred women on 25 stations' under her command. ${ }^{41}$

Like their middle and upper-class brothers, New Zealand women who volunteered for the war effort overseas drew on the vocabulary of patriotic duty in describing their motives for volunteering. ${ }^{42}$ Upon the outbreak of war, Gladys Luxford begged her chaplain father to 'get me to Egypt if possible, so as I could do my little bit

\footnotetext{
37 'George Harry Black - personnel file,' AABK-18805-W5568 -0135130, ANZ.

38 William to Helen Rolleston, 18 July 1916, MS-0985-002/190, HL.

39 Helen Rolleston to William, 23 October 1916, MS-0985-002/190, HL. John Bowden died on 10 October 1916 , aged 22, of chest wounds received in France. 'John Desborough Bowden - personnel file,' AABK-18805-W55200016645, ANZ.

40 'Catherine Mabel Hislop - personnel file,' AABK-22525-W5614-94/37/55B, ANZ. Voluntary Aid Detachment nurses were women, usually with little training or experience, who were placed in understaffed military hospitals to supplement the work of trained nurses and doctors.

41 'Mrs Harriet Simeon - personnel file,' AABK-22525-W5714-37/3726, ANZ. Women's military auxiliaries such as the Women's Royal Airforce, Women's Army Auxiliary Corps, and Women's Royal Naval Service typically drew their 'ranks' from among the working classes, while selecting middle- or upper-class women as officers. See Watson, Fighting Different Wars, 33.

42 Watson, Fighting Different Wars, 86.
} 
for my country'. ${ }^{43}$ Egypt 'proved an impossibility' but Gladys eventually secured a passage to England, where she and her mother travelled early in 1918, and where Gladys took up VAD work. ${ }^{44}$ It is probable that additional motives (such as a sense of adventure or a desire to see the world) also underpinned such women's decisions to volunteer their services. ${ }^{45}$ However, the tendency of the middle and upper classes to see the war as 'service' or 'selfishness' made the expression of motives that were anything other than purely altruistic appear suspect. Travel for family reasons was not regarded as selfish if undertaken by women and in many women's cases it is likely that the motivations of being near family and desire to serve the war effort overlapped. This was the case for Ethel Hurst, who travelled from Auckland to England with her mother in 1916 to be nearer their brother and son, Ben Hurst. While in England, Ethel volunteered at an army canteen and soldiers' club before taking on a position as a VAD nurse. She returned home with her mother after Ben's death in France in $1918 .{ }^{46}$

The research for this thesis has identified 263 New Zealand women who participated in voluntary war work overseas. These women engaged in a wide variety of occupations in support of the war effort. As seen below in Figure 2.1, the majority (139 in total) volunteered as VAD nurses in the large New Zealand hospitals, or in support roles attached to hospitals, while 67 women volunteered at soldiers' canteens and clubs. ${ }^{47}$ Most resided and worked in England during the war, although 31 undertook voluntary work in Egypt and 18 volunteered in France. As Janet Watson has noted of British war workers, the occupations of such volunteers can be positioned along 'a spectrum of responsibility, ranging from those that were consistent with cultural ideas about "women's work" to those that disrupted gendered norms considerably". At the more respectable end of the spectrum lay roles such as VAD nursing which drew upon

\footnotetext{
43 Gladys Luxford, 'How I Came to be Interested in War \& Why I Went to World War One', MS 94/6, Auckland War Memorial Museum (AWMM).

44 Ibid.

45 The war diary of Enid Bell, who worked as a volunteer ambulance driver in France, clearly conveys the sense of excitement and novelty she derived from her experience. Beatrice Enid Bell, war diary 1917, MSDL-0674, ATL (available through First World War Experiences database; accessed 3 March 2014).

${ }^{46}$ Ethel Hurst's story was related in the memoir of her friend and fellow war worker Gladys Luxford. Luxford, 'How I Came to be Interested in War'. See also 'Ethel Hurst - personnel file,' AABK-22525-W5714-2/37/214B, ANZ.

47 Archives New Zealand holds a list compiled by the NZEF Principal Matron Miss Thurston which purports to contain the names of 148 women who worked as VAD nurses in New Zealand Military Hospitals and were domiciled in New Zealand prior to 1914. Cross-checking of this lists against the details available in personnel records suggests that it is unreliable: and includes the names of both local British women with no connection to New Zealand and British women who married New Zealand soldiers during the war. It also omits the names of some known New Zealand war workers. The figure of 263 cited above was reached through a combination of newspaper research and reference to information contained in digitised personnel records. For Miss Thurston's list see 'Demobilisation Gratuity - Nurses and VAD workers,' AAYS-8638-AD1-1053- 75/26/11, ANZ.

48 Watson, Fighting Different Wars, 105-106.
} 
nurturing qualities regarded as essentially feminine. At the opposite end lay women agricultural workers, ambulance drivers and members of women's paramilitary organisations: who transgressed traditional gender norms through their clothing or through the dirty, physical or dangerous nature of their work. Even occupations which appeared on the surface to conform to traditionally feminine behaviour could subvert them in reality. ${ }^{49}$

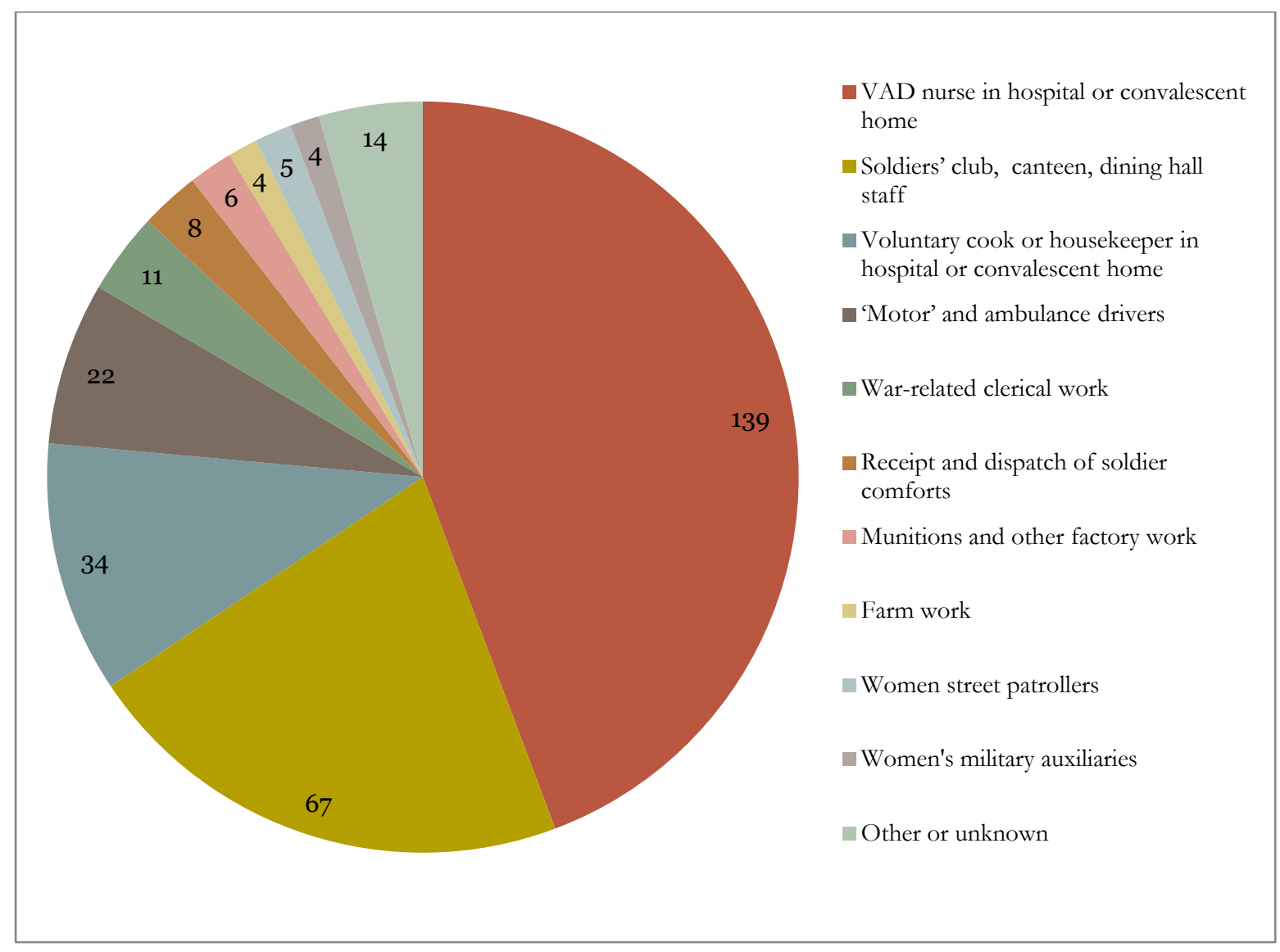

Figure 2.1: Occupations of New Zealand Women War Workers Overseas

Note: figures under each total do not match the total number of war workers as some women undertook more than one of these occupations.

While middle- or upper-class patriotic women framed their wartime service using the same notions of duty as their male relatives, the way that they ranked their wartime duty in relation to their domestic responsibilities differed from men. Unlike men mobilised as part of military forces, female war workers were expected to prioritise duty to family over service to the war effort as soon as the two conflicted. Unlike soldiers, women

${ }^{49}$ Ibid., 86. 
volunteers faced no serious sanctions for abandoning their wartime duties. ${ }^{50}$ The Stewart's Dunedin friend Hazel Buckland volunteered at the Walton-on-Thames and Brockenhurst military hospitals from July 1915 until the end of the war. Her work was frequently interrupted by her mother's illnesses and the need to care for her school-aged brother during his holidays. ${ }^{51}$ 'She just loved Mt Felix [Walton-on-Thames hospital] \& didn't want to leave', Hazel's fiancee reported on one such occasion, 'but Mrs B. \& boy got ill so poor old [Hazel] had to fly to their help - She is just longing to do something, ${ }^{52}$ Several women were forced to abandon their war work altogether when more pressing family duties arose. Laura Salmond, who worked as a farm labourer before starting at Walton-on-Thames in September 1917, resigned in May 1918 after receiving a cable that her mother back in New Zealand was seriously ill: 'Being the only girl I feel it my duty to go home as soon as possible'. ${ }^{53}$ Auckland woman May Gutteridge resigned from her VAD duties in September 1918 to return to New Zealand as she was 'needed at home for 3 months'. ${ }^{54}$ Thus, as later chapters will demonstrate, men were routinely pressured or compelled to prioritise the war effort over their domestic obligations, the belief that women's primary responsibility should reside with family did not alter during the war.

\section{Obstacles to travel}

Those New Zealand women wishing to travel overseas, whether for family reasons or to assist in the war effort, faced growing obstacles to their travel. Not least among these was government resistance to women's travel. The form that women's duty took was shaped throughout the war by an official reluctance to allow women to serve in overseas theatres of war. The main body of NZEF troops, which departed in October 1914, contained no professional nurses, and the government consented to the sending of the first contingent of trained nurses only after sustained lobbying on the part of the New Zealand Nurses Association. ${ }^{55}$ While the New Zealand government eventually relaxed its restrictions on professional nurses, it remained steadfastly opposed to proposals to send parties of untrained female volunteers overseas. The government's stance on such

\footnotetext{
50 Ibid., 92.

51 'Hazel Buckland - personnel file, AABK-22525-W5714-1/37/14B, ANZ. Hazel Buckland left New Zealand for England in February 1914, for unknown reasons. By November 1916, her mother Mrs Buckland had sufficiently recovered her health to take a voluntary position running the Brockenhurst Hospital Gift Store.

52 Bernard de Lautour to Mary, n.d., MS-0985-051/016, HL.

53 Laura Salmond to Miss Thurston, 15 May 1918 in 'Annie Laura Salmond - personnel file,' AABK-22525-W5714-

$1 / 37 / 114 \mathrm{~B}, \mathrm{ANZ}$.

54 'May Valentine Gutteridge - personnel file,' AABK-22525-W5573-14/37-42B, ANZ.

55 Tolerton, Ettie, 105.
} 
volunteers is illustrated through its prolonged battle with Christchurch activist Ettie Rout over her plans to form a Volunteer Sisterhood to work with New Zealand soldiers in Egypt. Rout eventually succeeded in spite of official opposition and the first contingent of her Volunteer Sisterhood set sail for Egypt in October 1915. ${ }^{56}$ The members of a party of five New Zealand women who travelled to Egypt to staff a convalescent home opened by Lady Louisa Godley, wife to the commander of the NZEF, were the only such volunteers to travel with official sanction and to be attested as members of the NZEF. All other volunteers mentioned in this chapter travelled under their own devices and were never officially recognised, even when they worked at New Zealand military hospitals. The partial or sometimes non-existent nature of the army's record-keeping in relation to such volunteers was only one consequence of the official refusal to recognise their service: their lack of formal status as NZEF medals made them ineligible for medals as well as other benefits, such as free railway travel, awarded to returned servicemen.

With the exception of Lady Godley's party and Rout's first contingent of volunteers, those female volunteers who travelled overseas during the war were those wealthy enough to cover their own travel expenses. The distances between New Zealand and overseas theatres of war made such travel an expensive undertaking. The cost of a one-way passage from New Zealand to England, which ranged from $£ 16$ for a steerage passage and over $£ 40$ for first class, would have been beyond the reach of most women. ${ }^{57} \mathrm{~A}$ few working-class women did manage to travel overseas under their own auspices during the war. Angela Woollacott cites the example of Australian woman Mary Brennan who saved her wages as a maid in a Western Australian bush-hotel to pay her passage to England to become a war worker. ${ }^{58}$ Certainly, not all the New Zealand women included in this chapter's analysis drew upon family wealth to travel overseas. Ellen Dobbie, employed by Cooke \& Sons Shipping agents before the war, later informed the Defence Department that she 'drew all my savings from the Bank to pay my passage to Blighty in May $1915,{ }^{59}$ Added to the cost of travel were living expenses. The cost of living in Egypt was particularly high. In 1915 Elizabeth wrote: 'I have heard of two or three ladies from Australia, who have been doing splendid work here from the

\footnotetext{
56 Ibid., 117.

57 'Shipping,' New Zealand Herald, 26 June 1915, 1. A passage in steerage would have represented over a month's wages for a labourer on the lowest arbitration award rate of $£ 132.2 .0$ in 1916, but women earned between a third and a half less than this.

58 Woollacott, To Try Her Fortune, 169.

59 'Ellen Locker Dobbie - personnel file,' AABK-22525-W5714-9/37/4588, ANZ.
} 
beginning, who say they cannot manage any longer \& talk of going home. Doesn't it seem a shame? ${ }^{90}$ The fact that most volunteers were either unpaid or received a minimal living allowance meant that volunteering opportunities were likely to be confined to the financially secure. Thus it is likely that most New Zealand volunteers, like their British counterparts, came from privileged social backgrounds. ${ }^{61}$

After 1915, dominion women wishing to travel overseas faced increasing government restrictions on their movements. While the war democratised travel for soldiers and nurses who travelled under the auspices of military forces, it had the converse impact upon civilian travel: both absorbing shipping capacity and heralding the introduction of strict new border control regimes as states sought to police the movements of both 'enemy aliens' and their own nationals. ${ }^{62}$ From November 1915, travellers wishing to leave or enter Britain were required to hold a passport and similar passport controls were imposed for Egypt, under British protectorate. ${ }^{63}$ In New Zealand two groups - civilian men of military age and women of all ages - found their freedom of movement increasingly restricted as the war progressed. In November 1915, the New Zealand government issued a regulation specifying that no person over the age of fifteen years would be permitted to leave the country unless 'on the King's Service' or having first obtained a government permit. ${ }^{64}$ As conscription historian Paul Baker notes, the new rule was partly intended to stem the flow of single men of military age to Australia and the United States in advance of the New Zealand government's introduction of military conscription. ${ }^{65}$ But other new travel restrictions explicitly targetted women. By late 1915, the British authorities had issued an order rescinding the ability of its officials to grant permits to the female relatives of officers wishing to enter Egypt. ${ }^{66}$ The British Australasian commented that the new rule would affect the 'great numbers' of Australian women who had 'found Egypt a convenient pied-de-terre during

\footnotetext{
${ }^{60}$ Elizabeth to Rachel and Mary, 28 August 1915, MS-0985-041/001, HL.

61 Watson, Fighting Different Wars, 84.

62 On the democratisation of travel for soldiers during the war see Richard White, 'The Soldier as Tourist: The Australian Experience of the Great War', War \& Society (May 1987): 63-77; Bart Ziino, 'A Kind of Round Trip: Australian Soldiers and the Tourist Analogy 1914-18,' War \& Society 25, no. 2 (2006): 39-52. For the increasing regulation of civilian travel in wartime see Craig Robertson, The Passport in America: The History of a Document (Oxford: Oxford University Press, 2010), 185; John Torpey, 'The Great War and the Birth of the Modern Passport System,' in Documenting Individual Identity: The Development of State Practices in the Modern World, eds., Jane Caplan and John Torpey (Princeton: Princeton University Press, 2001), 256-270.

63 'Permits and Passports,' New Zealand Official Year Book, 1916, Section III, URL: http://www3.stats.govt.nz/ New_Zealand_Official_Yearbooks/1916/NZOYB_1916.html, accessed 4 March 2014.

64 Ibid.

${ }^{65}$ Baker, King and Country Call, 44.

66 'No Women in Egypt,' British Australasian, 23 December 1915.
} 
the past year, since it was as near as possible to their sons and husbands at the front. ${ }^{.67}$ Speculating upon the reasoning behind the new rules, the same paper judged the dangers of German attack as well as the problems created by 'well-intentioned but useless women who consider Egypt a happy hunting ground for their alleged war work' to be likely factors. ${ }^{68}$ In February 1917 the Imperial authorities issued an order expressly forbidding the issuing of passports to women, except 'in cases of exceptional necessity' and this measure was enacted by the New Zealand and Australian governments soon afterwards. ${ }^{69}$ This time, the British Australian considered wartime threats to shipping and a desire to free up space for cargo, teamed with the 'chivalric code' which deemed women's safety a 'first charge upon the ship's company' to be the likely reasoning behind the regulations. But it queried why 'men trippers' were exempted from the restrictions, commenting that 'men without urgent business in England are not wanted either'. ${ }^{70}$ These strict controls on travel certainly impeded the travel plans of at least some New Zealand women. Mary Gertrude Meads, the fiancee of a soldier acquaintance of Elizabeth's, unsuccessfully attempted to obtain a passport to travel to England in 1918. ${ }^{71}$ Nevertheless, continued references to the departure of women from New Zealand after February 1917 suggests that at least some women managed to travel in spite of the new restrictions, presumably because they either already possessed passports, or were able to convince authorities that theirs was a case of 'exceptional necessity'.

\section{New Zealand institutions for New Zealanders}

A community of New Zealand travellers overseas during the war formed the core organisers, donors, and personnel for a series of institutions set up to look after the welfare of New Zealand soldiers. In Egypt, the first dedicated hospital for New Zealand soldiers was opened at Pont de Koubbeh, Cairo, in April 1915. ${ }^{72}$ Another New Zealand

\footnotetext{
${ }^{67}$ Ibid.

${ }^{68}$ Ibid.

69 'In the Looking Glass,' The British Australasian, 19 April 1917, 16. See also McLeod, 'Activities of New Zealand Women During World War One,' 35.

70 'In the Looking Glass,' The British Australasian, 19 April 1917, 16.

${ }^{71}$ Elizabeth, who had met the soldier when she was working at the New Zealand Military Hospital at Brockenhurst, wrote to William in August 1918 to ask him to move "the powers that be" on Mead's behalf. Elizabeth to William, 10 April 1918, MS-0985-007/004, HL. An enclosed letter from Mead's fiancee, Charles Gauntlett, explained that he wished Miss Mead to travel to England to be his wife, stating: 'Miss Mead is a teacher \& of course is qualified for all that is necessary in regard to V.A.D. Duties, ie. First Aid \& Nursing: if she cannot leave N.Z. simply to become my wife, perhaps she can leave as a War worker.' Charles Gauntlett to Elizabeth, 3 April 1918, MS-0985-007/004, HL. William's representations on Mead's behalf were unsuccessful and the pair eventually married upon Gauntlett's return to New Zealand in 1919.

72 This hospital was further expanded after the arrival of a full hospital equipment and staff from New Zealand in July 1915.
} 
military hospital was opened in the Egyptian city of Port Said in June 1915. Elizabeth and Agnes began work at the Pont de Koubbeh hospital in October 1915, following a brief stint volunteering at a nearby British military hospital. ${ }^{73}$ Louisa Godley's convalescent home for New Zealand soldiers in Alexandria had opened by July $1915 .^{74}$ Another convalescent home for New Zealand soldiers, the Aotea Home, funded by the 'citizens of Wanganui', opened in Cairo in October $1915 .{ }^{75}$ In addition, New Zealand volunteers in Egypt established a series of huts and clubs to cater for the recreational needs of soldiers. These included a series of huts set up by Rout and staffed by the members of her Volunteer Sisterhood. ${ }^{76}$ The New Zealand branch of the YMCA also founded clubs in Egypt. ${ }^{77}$ Elizabeth began work at a 'British Cafe' established at Heliopolis by English woman and one-time Wellington resident Mrs Edith de Castro, but soon joined a committee of Australian women who planned to establish their own soldiers' club. ${ }^{78}$ Their club, which they named 'The Empire Club', was located directly opposite the site of an Australian military hospital, and attracted the patronage of mostly Australian troops.

In the United Kingdom, an organisation to cater for the needs of New Zealand soldiers was established almost immediately upon the outbreak of war. The New Zealand War Contingent Association (NZWCA) was formed out of a meeting of the elite expatriate network the New Zealand Association in August $1914 .^{79}$ Its inaugural meeting boasted an attendance of 'about three hundred of the leading New Zealanders in the Old Country'. ${ }^{80}$ By October 1914, the NZWCA had issued circulars soliciting assistance from 'as many New Zealanders now in the United Kingdom whose addresses could be found, and also to the numerous trading concerns doing business with the dominion, about 3,000 in all'. ${ }^{81}$ By the same month, the Association had shifted its headquarters to the Strand, and into offices offered to it 'practically free of expense' by

\footnotetext{
73 Elizabeth to Mary and Rachel, 26 October 1915, MS-0985-041/001, HL.

74 'Convalescent Home in Cairo,' Otago Daily Times, 15 July 1915, 8; 'Lady Godley's Work for the Sick and Wounded,' Dominion, 29 July 1915, 3.

75 'Aotea Convalescent Home,' Wanganui Chronicle, 29 November 1915, 6.

76 'Tolerton, Ettie, chapter nine.

${ }^{77}$ For the New Zealand YMCA during the war see Ria Keenan, 'On the Triangle Trail: The New Zealand YMCA and the Great War,' in New Zealand's Great War, eds., Crawford and McGibbon, 354-363.

78 The sisters had met their fellow committee member Mrs Chisholm and her daughter Sheila, members of an elite Sydney family, on the passage from Melbourne to Cairo, and realised their mutual acquaintance in Elizabeth's Otago friends, the Mackerrases. Later in the war the Chisholms travelled to England, where their movements can be traced through reports in the British Australasian.

${ }^{79}$ Report of the NZWCA 1914, AD1-887-39/189, ANZ.

${ }^{80}$ Ibid.; Felicity Barnes, New Zealand's London. A Colony and its Metropolis (Auckland: Auckland University Press, 2012), 58.

81 Report of the NZWCA 1914, AD1-887-39/189, ANZ.
} 
another influential imperial network: the Victoria League. ${ }^{82}$ Its location within one minute's walk of the New Zealand High Commissioners' Office was particularly convenient as the two organisations shared the same leadership. High Commissioner Sir Thomas Mackenzie was also, for much of the war, chairman of the NZWCA, while his daughter Helen Mackenzie fronted the Association's active Ladies' Committee. ${ }^{83}$

One of the NZWCA's first actions was to open the first dedicated hospital for New Zealand soldiers at Walton-on-Thames, Surrey, in August $1915 .{ }^{84}$ The hospital's administration was subsequently taken over by the New Zealand military authorities, which opened three further New Zealand military hospitals: at Brockenhurst, Hampshire in June 1916; at Codford, Wiltshire in July 1916; and at Hornchurch, Essex in July 1916. A New Zealand officers' home was opened at Brighton in May 1916. While the New Zealand Hospital at Port Said remained in use for the duration of the war, the staff and patients of the Pont de Koubbeh hospital at Cairo were shipped to Brockenhurst following the relocation of the New Zealand Military Headquarters to England in 1916. ${ }^{85}$ Elizabeth and Agnes took roles as VAD nurses in the wards of the Brockenhurst hospital in August 1916. While Agnes continued her work in the wards for the duration of the war, Elizabeth worked as Superintendent of the Brockenhurst Dining Hall from October 1917 until 1919.

\footnotetext{
82 Ibid.

83 Incidentally, Sir Thomas, a one-time New Zealand Prime Minister whose gardener father had settled in Dunedin in the 1850s, also had long-standing connections with the Stewart family, whose maternal grandmother Rachel Paterson was said to have been responsible for arranging for the education of Thomas and his brother James. According to Rachel Armitage, both Thomas and James Mackenzie 'always recognised that it was to [Rachel Paterson] that they owed their opportunity in life'. MB-458-2/13, MBL.

84 '[S]ome twelve hundred New Zealanders' living in England were invited to the hospital's opening, and several hundred of these attended. 'The New Zealand Hospital,' British Australasian, 5 August 1915, 16.

${ }^{85}$ Major Bowerbank, 'New Zealand Hospitals in Egypt,' in The War Effort of New Zealand (Auckland: Whitcombe \& Tombs, 1923), 113-115, under 'New Zealand in the First World War 1914-1918,' NZETC, URL: http://nzetc.victoria.ac.nz/tm/scholarly/tei-WH1-Effo.html, accessed 29 July 2013.
} 


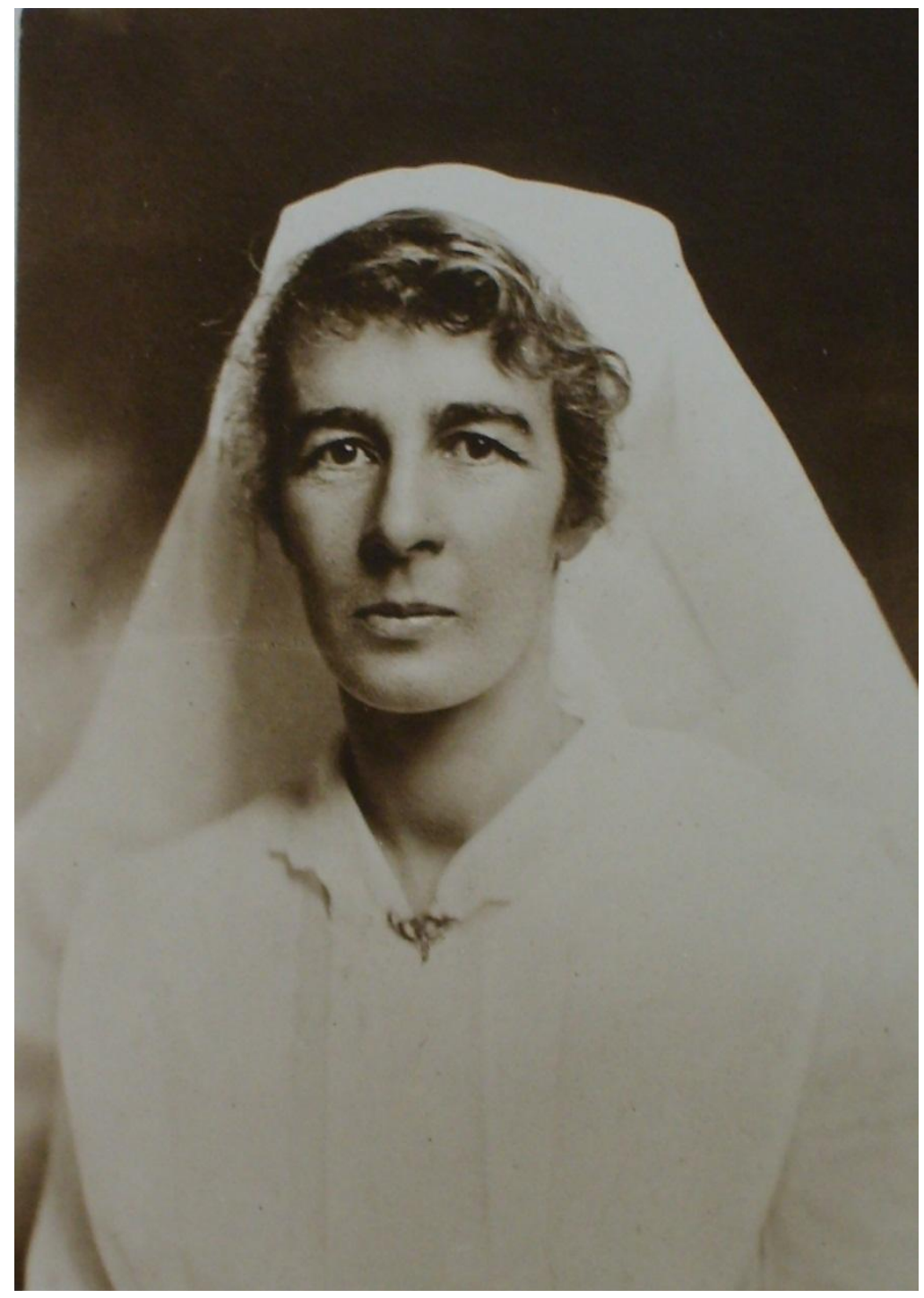

Figure 2.2: Elizabeth Stewart in VAD uniform, 1916

Source: MS-0985-057/003, HL. ${ }^{86}$

Another important branch of the NZWCA's wartime work was its establishment of a series of recreational clubs for New Zealand soldiers in the United Kingdom. The NZWCA established clubs in the proximity of New Zealand military camps (such as the NZ Soldiers' Club at Salisbury), hospitals (such as the Kia Ora Club at Brockenhurst or the Haeremai club at Walton-on-Thames) and at popular leave destinations for New Zealand soldiers (the NZWCA Soldiers' Club at Russell Square, London). ${ }^{87}$ The NZWCA was joined in its efforts by the New Zealand YMCA whose recreation huts

${ }^{86}$ Elizabeth's note accompanying this photograph explained: 'They are taken before I left London ...I thought my friends might like the association - I only wore what I worked in, in Egypt - all white - Here we wear blue.' Elizabeth to Mary and Rachel, 20 September 1916, MS-0985-041/002, HL.

87 Other soldiers' clubs run by the NZWCA included the Southhampton Row Club Rooms (London), the Ao-tea-roa Club (Codford), the Haeremai Club (Walton-on-Thames), Te Arohanui Club (Oatlands Park), NZ Military Nurses' Rest Home (Ken), Recreation Rooms (Torquay), and ‘Te Wharepuni’ (Hornchurch). 
covered virtually every location New Zealand troops were stationed at during the war. ${ }^{88}$ The NZWCA and YMCA clubs, discussed further below, offered visiting soldiers temporary accommodation, entertainment, food and refreshments, and spaces for reading and writing.

The High Commissioner's office, via the NZWCA, also acted as a labour exchange for New Zealand women seeking voluntary work for the war effort in the United Kingdom. In 1916, the High Commission reported having received '[a] very large number of applications...from New Zealand ladies desirous of offering their services in connection with the war'. ${ }^{89}$ It further noted that its results in obtaining appointments for such ladies had so far been 'highly satisfactory'..$^{0}$ As noted previously, not every New Zealand volunteer worked for a New Zealand organisation. But, once the option of working with New Zealand soldiers became available, many New Zealand women gravitated towards the new institutions. Mabel Deck, the widow of a Canterbury soldier killed at Gallipoli, and living in England, wrote to Helen Mackenzie in April 1917 to enquire how she might apply for VAD work: 'It is such a waste of time for me to be idle if I can be of any use at all. I would feel happier working too especially as I left NZ for that purpose'. ${ }^{91}$ She expressed her preference for working with New Zealand soldiers: 'I see by today's paper that VAD workers are urgently needed for Imperial Army both for Home \& Abroad. I shall apply for this work if NZ Army is not in need but want to enquire first'. ${ }^{92}$ In May 1917, New Zealand woman Margaret Middleton wrote to apply for work at Brockenhurst. Middleton was a trained cook with twelve years experience. She explained: 'My NZ friend, Miss [Margaret] Latter, and I have been cooking for a month at Shorncliffe, a Canadian camp, but would so much rather work for our own men'.93

\footnotetext{
${ }^{88}$ Keenan, 'On the Triangle Trail'. In France, the 'Lowry Hut' for New Zealand soldiers, the gift of Mrs Lowry, was staffed by 'five ladies and two secretaries'. 'Camps - YMCA - social work with NZEF 1917,' AD1-742-12/103/1, ANZ.

${ }^{89}$ It further noted three main categories of applicant: 'Trained nurses', 'Red Cross Workers who are not trained nurses' and 'Ladies without nursing experience of any kind'. Annual Report of the High Commissioner for New Zealand for 1916, AJHR, 1918, H-33, 3.

${ }^{90}$ Ibid.

${ }^{91}$ Mabel Deck to Miss Mackenzie, 19 April 1917, in 'Mabel Annie Deck - personnel file,' AABK-22525-W5714-B.R.37/197B, ANZ. Mabel Deck's husband, Lieutenant Robin Howell Deck embarked with the Canterbury Mounted Rifles, NZEF in February 1915 and was killed in action at Gallipoli on 29 August 1915, aged 25 years. 92 Ibid.

${ }^{93}$ Margaret Middleton to Miss Maclean, 8 May 1917, in 'Miss Margaret Middleton - personnel file,' AABK-W561422526-95/37/191B, ANZ.
} 


\section{Recreating Home}

Workers at voluntary institutions for soldiers frequently described their aims as to create substitute homes for men whose own homes and families were far distant. Like the female leaders of patriotic organisations discussed in the previous chapter, the vocabulary of fictive kinship was central to how they described their work. In sharing her committee's plans for their Empire club, Elizabeth wrote: 'We want a place that will be nice $\&$ home like for the boys - somewhere they can come to read \& write \& have music - also a light tea (at a reasonable price) - served by English speaking women; ourselves \& others who are anxious to help. ${ }^{94}$ Judging from the reported feedback of soldiers visiting the club, their efforts to create a homelike environment had its desired effect: 'Every boy uses the same expression in connection with the impression it gives him - It is always - "this is the nearest to home we've struck since we left" - or "this makes me feel as tho' I'm home again" - etc. always the touch of "home" we were so anxious the boys should consciously or unconsciously feel \& be helped by'. ${ }^{95}$

An important element of recreating 'home' for soldiers lay in creating spaces that looked like homes, an effect that volunteers sought to achieve through the addition of decorations such as flowers, tablecloths and pictures. ${ }^{96}$ Of the British Soldiers' Cafe, Elizabeth wrote: 'Of course we get lots of boys in for a chat \& we always have the room as pretty \& homelike as possible with flowers \& photos about everywhere'. ${ }^{97}$ The Egyptian Gazette's account of the Empire Club described it as 'a dainty, well-kept, and scrupulously clean tea room, where papers are provided and flowers adorn every table, the flowers being the daily gift of Prince Dared, the son-in-law of the Sultan, who has in addition presented to the club the nucleus of a library for the use of the men'. ${ }^{98} \mathrm{~A}$ female volunteer described the NZWCA's club at Salisbury in similar terms: 'We try to make the Club as much like a home as possible, and judging by the remarks in the Visitors' Book the men look upon it as such'. ${ }^{99}$ She further observed that the part of the club 'given up to little tea tables with real table cloths and flowers... seems to appeal to the

\footnotetext{
94 Elizabeth to Mary and Rachel, 3 January 1916, MS-0985-041/001, HL.

95 Elizabeth to Mary and Rachel, 30 January 1916, MS-0985-041/002, HL.

96 British religious organisations similarly emphasised the importance of domestic details in recreating home-like environs for British soldiers fighting overseas. Jeffrey Reznick, Healing the Nation: Soldiers and the Culture of Caregiving in Britain During the Great War (Manchester: Manchester University Press, 2004), 23.

97 Elizabeth to Mary, 23 March 1916, MS-0985-050/002, HL.

98 untitled newspaper clipping, n.d., in MS-0985-033/008, HL.

${ }^{99}$ Italics in original. 'Salisbury Letter,' Chronicles of the NZEF, 15 September 1916, 34.
} 
men more than anything. ${ }^{100}$ Such feminine domestic touches, were, in the eyes of both club organisers and soldier patrons, important aspects of what made such institutions 'home-like'.

The presence of female volunteers was key to these institutions' efforts to recreate home for their soldier patrons. Elizabeth wrote in January 1916: 'You have no idea how much the boys appreciate a chat with an English woman - it is quite touching when they try to tell us - as a great many do - how [they] long for the "home touch". ${ }^{101}$ Female volunteers completed the imagery of clubs as 'homes' as in the Victorian traditions of domesticity described by Davidoff et. al., where women not only defined the home as the 'sphere where femininity was maintained' but 'in a sense...became the house'. ${ }^{102}$ At least some of the volunteers at such institutions readily identified with others' descriptions of them as 'mothers' to the men who visited such clubs. Dunedin woman Miss Hay, in charge of the NZWCA's Salisbury Club was, according to one of her fellow volunteers, "commonly known to the men as "Mother," and seems to thoroughly appreciate the compliment'. ${ }^{103}$ Elizabeth also identified with a mothering role, attributing her affinity to working with the most severe 'cot cases' in the wards to 'the "mother" in me, reaching out to them'. ${ }^{104}$

In acting as substitute 'mothers' or 'sisters' to soldiers, some female volunteers envisaged themselves as proxies for men's own mothers and sisters back home. ${ }^{105}$ Some soldiers certainly viewed the volunteers in this way. In praising the work of the YMCA's club at Ezbekia Gardens in Cairo, Rout wrote: 'Time and time again, men would say, "My mother will be glad when she hears about this." 106 Similarly, after describing the manager of the NZWCA's club at Hornchurch as 'A mother to us all', one New Zealand soldier wrote: 'It would be A1 if the mothers and sisters of us boys dropped in to see how well we are catered for'. ${ }^{107}$ Recreating the atmosphere of home, Elizabeth believed, also brought men closer to their families back in New Zealand: 'Even our little room at the British Soldiers' Café draws them because of the flowers \& odd photos that

\footnotetext{
100 Ibid.

101 Elizabeth to Rachel and Mary, 3 January 1916, MS-0985-041/001, HL.

102 Davidoff et. al., The Family Story, 84. Barnes describes the female volunteers at such clubs as 'maternal archetypes'.

Barnes, New Zealand's London, 60-61.

103 'Salisbury Letter,' Chronicles of the NZEF, 15 September 1916, 34.

104 Elizabeth to Rachel, 9 August 1917, MB-391-4/26, MBL.

105 Winter, Sites of Memory, Sites of Mourning, 30.

106 Tolerton, Ettie, 123.

107 'Salisbury Letter,' Chronicles of the NZEF, 15 September 1916, 34.
} 
suggest home to them - And they are all such dears - \& such boys, even the oldest of them - they all have their photos to show - if it isn't "the wife \& kiddies" - its "my mother" \& “my girl"”. ${ }^{108}$

Felicity Barnes has located the efforts of New Zealand volunteers to create 'homes away from home' for New Zealand soldiers visiting London within a larger cultural project of mapping New Zealand onto London metropolitan space. ${ }^{109}$ The features of such clubs were, however, largely uniform across a range of locations across Britain, as well as in countries with which New Zealanders had fewer historical and cultural associations. The efforts of New Zealand volunteers to recreate home for their soldiers also replicated those of other nation's volunteers. Historian Jeffrey Reznick, writing of the work of the British YMCA, Church Army, and Salvation Army, describes the aims of these organisations in creating recreational huts for British soldiers overseas as to 'replicate whenever and wherever possible the meaning and social experience of the middle-class "home away from home", a space alternative both to the trenches and to local recreations. ${ }^{, 110}$

The homes envisaged by voluntary organisations echoed nineteenth-century middle-class ideals of domesticity, as described by John Tosh. It was only in the home, middle-class Victorians believed, that a man could 'be truly and authentically himself. ${ }^{111}$ Notions of home as a refuge and as the only place in which a man could truly relax and unburden himself from the cares of the outside world are evident in a number of soldiers' accounts of New Zealand clubs. One New Zealand soldier wrote of the NZWCA's London club: 'When a man crosses the threshold of No 17 Russell Square, he is back again in N.Z., and as such he is able to feel more at home. The feeling of restraint, which is so often met with in some of the other clubs, is quite absent here... ${ }^{, 12}$ In other descriptions, 'home' was the place that gave men the strength to face the outside world with confidence. Writing of the YMCA's Sling Camp Hostel and its New Zealand manager, Mrs Mylrea, one New Zealand soldier described her role as 'that

\footnotetext{
108 Elizabeth to Rachel and Mary, 3 January 1916, MS-0985-041/001, HL.

109 Barnes, New Zealand's London, 42.

110 Reznick, Healing the Nation, 18.

111 Tosh, A Man's Place, 33.

112 'London Club Letter,' Chronicles of the NZEF, 15 September 1916, 36.
} 
which helps to put a man back on his feet, and enables him to look the whole world in the face. ${ }^{113}$

Another key objective of volunteers in creating 'homes away from home' for soldiers was to provide recreational opportunities alternative to the temptations of the street. In one letter, Elizabeth referred obliquely to the well-known moral dangers of the streets of Cairo for colonial soldiers when she described the city as 'the last place in the world in which to have nothing to do \& a fair amount of spare cash'. ${ }^{114}$ Clara Rogers, a member of Rout's Volunteer Sisterhood, claimed in 1916 that a chief objective of the Ezbekiah Tearooms was 'to provide a place to keep the men off the streets': '[u]ntil one has seen Cairo it is impossible to conceive an idea of what vices exist or what temptations the boys are exposed to' ${ }^{115}$ Rout herself regarded her efforts to provide alternative recreational options for soldiers as complementary to her better-known work to promote the use of prophylactics among New Zealand troops. ${ }^{116}$ In these institutions middle- or upper-class female volunteers were the foil to the attractions of non-white women on the streets. Here, as elsewhere in the British Empire, 'middle class womanhood was...seen as the antithesis of the unbridled sexuality of the "others". ${ }^{117}$ In England, and in London in particular, the sexual dangers of professional prostitutes and 'amateur women' alike were a concern to army authorities and voluntary organisations, and keeping soldiers away from the streets also formed part of the rationale for the NZWCA and YMCAs' clubs in that country. ${ }^{118}$

\section{Overcoming distance}

The emergence of institutions dedicated for the use of New Zealand soldiers abroad provided opportunities for soldiers to reconnect with friends, and to hear news of home and of other New Zealand soldiers. A 1923 history of the New Zealand medical service claimed that 'New Zealanders living in the United Kingdom early learned to look upon [the hospital at] Walton as the centre at which they were likely to find sick or wounded New Zealanders who had been transferred to the United Kingdom, or where they

\footnotetext{
113 'Y.M.C.A. and Chaplains at Sling,' Chronicles of the NZEF, 31 January 1917, 250.

114 Elizabeth to Mary, 12 April 1916, MS-0985-050/002, HL.

115 'Volunteer Sisters and the Y.M.C.A.,' Dominion, 23 February 1916, 3.

116 Tolerton, Ettie, 128.

117 Davidoff and Hall, Family Fortunes, xxxv. For the role of white women in the colonies as guardians of domesticity and racial purity see Ann Laura Stoler, Carnal Knowledge and Imperial Power: Race and the Intimate in Colonial Rule (Berkeley: University of California Press, 2002), chapter 2.

118 Barnes, New Zealand's London, 61-63; For representations of women's sexuality in wartime more generally see Grayzel, Women's Identities at War, chapter four.
} 
would be most likely to hear of the whereabouts of their soldier friends who were still in Imperial hospitals. ${ }^{119}$ Encounters with soldiers reported in Elizabeth's letters suggest that such national institutions could be valuable in fostering local connections. Meetings with West Otago men gained special mention in Elizabeth's letters, and were invariably accompanied by an exchange of news from home. After meeting with two Kelso men at the NZWCA's Russell Square club in London, where she worked several shifts in June 1917, Elizabeth reported 'It was nice to see them - I always like to get in touch \& with the local men $\&$ to hear $\&$ give what news there may be'. ${ }^{120}$

In the case of New Zealand soldiers stationed at the Western Front, the task of responding to families' enquiries about their whereabouts fell to the New Zealand High Commission, assisted by the NZWCA. ${ }^{121}$ In its annual report for 1916, the High Commission recorded having dealt with 'a great number of inquiries...by cable and by letter, regarding the location, condition and whereabouts of soldiers serving in the New Zealand, Imperial, and also the Australian forces'. ${ }^{122}$ Each of these, it noted, was 'dealt with most carefully', with 'the consolation to relatives quite justif[ying]' the extra workload for its staff. ${ }^{123}$ For soldiers hospitalised within the British isles, the task of gathering these reports was carried out by a network of female volunteers coordinated by the NZWCA's Ladies Committee. By 1917, this comprised 'upwards of 170 official honorary visitors, the large majority of them being either New Zealanders or closely connected with the Dominion'. ${ }^{124}$ Aside from representing 'probably the first visit a lonely New-Zealander receives in hospital in England', such visitors were also charged with reporting back weekly upon each soldier's condition. These reports provided the substance of the information that the High Commissioner's office forwarded to mens' next-of-kin back in New Zealand. ${ }^{125}$ Here, the NZWCA's volunteers performed the same role in relation to wounded soldiers as undertaken by Australian Red Cross bureaux for the missing, as described by Winter. Like the Red Cross volunteers in Egypt

\footnotetext{
119 Lieut. Col. Myers, 'New Zealand Hospitals in the United Kingdom,' in The War Effort of New Zealand, under 'New Zealand in the First World War 1914-1918,' NZETC, URL: http://nzetc.victoria.ac.nz/tm/scholarly/tei-WH1-Effot1-body-d6-d3.html; accessed 9 April 2013. sick, wounded, missing or killed. There are a large number of very distressing enquiries from New Zealand people, and there seems to be no one else here who can help the Y.M.C.A. secretary (Mr Jas. Hay) to do this work'. 'Miss Rout and the A.P.U,' Maoriland Worker, 3 May 1916, 8.

122 Annual Report of the High Commissioner for New Zealand for 1916, AJHR, 1918, H-33, 20.

123 Ibid.

124 Annual Report of the NZWCA, AJHR, H-40, 1917, 2.

125 Ibid.
} 
who searched for news of the missing, the efforts of the NZWCA's volunteers created an 'essential link' between soldiers and their relatives back home by 'open[ing] channels through which the families of men thousands of miles from home could seek information and receive it, even when it was painful. ${ }^{126}$ The NZWCA's volunteer visitors also personally facilitated soldiers' efforts to send information home by sending cables on soldiers' behalf or 'writ[ing] letters for those unable to write themselves'. ${ }^{127}$

Female volunteers affiliated with other New Zealand institutions also acted as conduits of information between individual soldiers and families back home. Before leaving Egypt in 1916, Elizabeth commissioned a photograph to be taken of the grave of Temuka man Thomas Horgan and sent to his mother back in New Zealand. ${ }^{128}$ Having received a grateful reply from Rachel, who had instigated the request, Elizabeth wrote 'I am glad the photos for Mrs Horgan arrived safely \& gave her some comfort'. ${ }^{129}$ Later that year, Elizabeth reported, again at Rachel's request, on the condition of a Temuka man named William Husband who had been admitted to Brockenhurst. ${ }^{130}$ During November 1916, Elizabeth and Agnes spent much of their spare time with another Brockenhurst patient, Len Nicholson, who was the brother of a Dunedin friend, whilst making enquiries as to the fate of another soldier brother: 'We have made enquiries in many quarters \& can learn nothing but there is really no doubt that the brother was killed on the $27^{\text {th }}$. ${ }^{131}$

\footnotetext{
126 Winter, Sites of Memory, Sites of Mourning, 37, 44.

127 Annual Report of the NZWCA, AJHR, H-40, 1917, 2.

128 Temuka man Thomas Horgan died of pneumonia in an Egyptian military hospital in November 1915. 'Thomas Horgan - personnel file,' AABK-18805-W5541-0056652, ANZ. Elizabeth wrote in February 1916: 'I am so glad Rachel to be able to tell you that I will be able to get you a photo of Horgan's grave \& will post it off as soon as I possibly can' Elizabeth to Mary and Rachel, 18 February 1916, MS-0985-050/002, HL.

${ }^{129}$ Elizabeth to Rachel, 28 June 1916, MS-0985-041/002, HL.

${ }^{130}$ Elizabeth to Rachel, 17 January 1918, MB-391-4/26, MBL.

131 Elizabeth to Rachel and Mary, 16 November 1916, MS-0985-041/002, HL.
} 


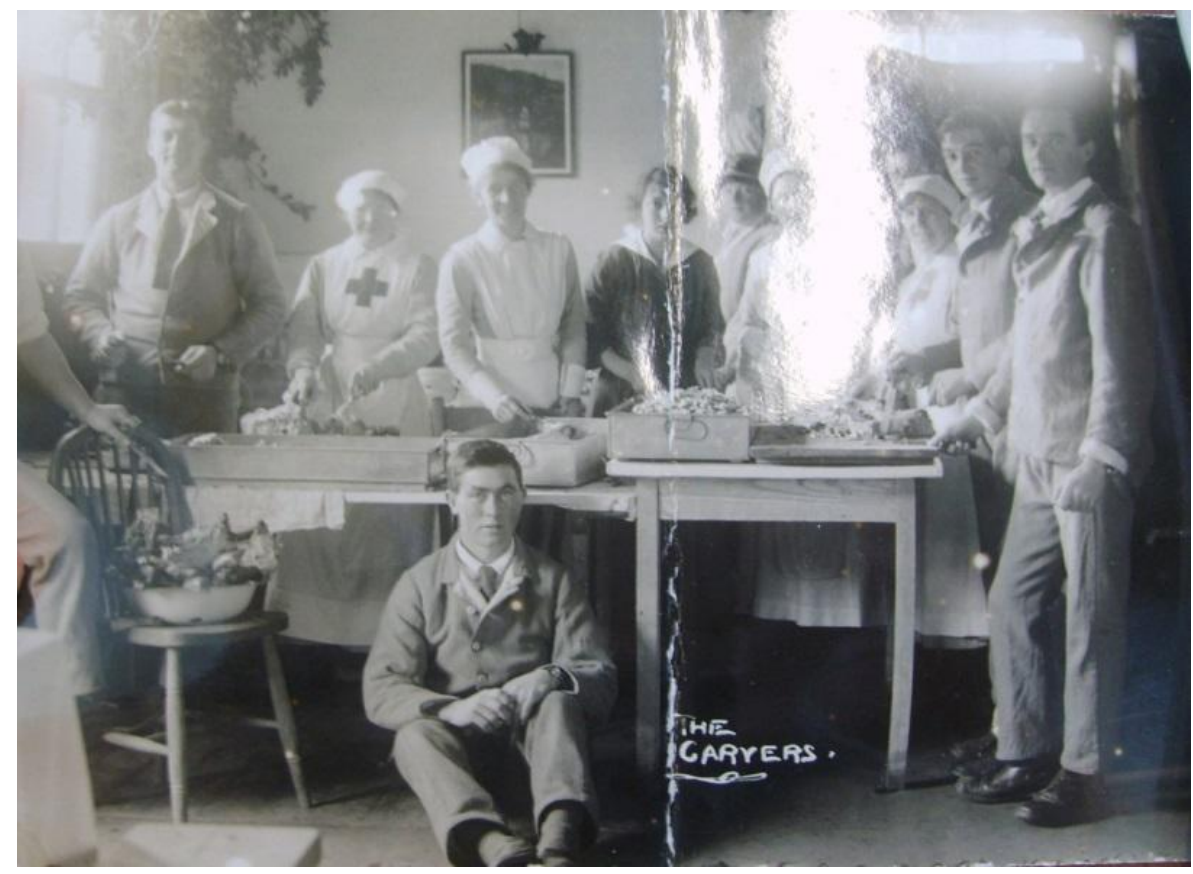

Figure 2.3: Elizabeth and group at Brockenhurst Dining Hall

Source: MB-391-4/26, MBL. ${ }^{132}$

The NZWCA and its Ladies Committee formed one of the most significant reception points for goods and funds collected for patriotic causes back in New Zealand, and a crucial link back to New Zealand-based groups such as the OSWPA. By August 1915, the OSWPA was shipping its shirts, under-shirts and socks for New Zealand soldiers directly to the NZWCA, while the Ladies' Committee also received shipments of Dominion Parcels, and cases of hospital comforts sent via the Red Cross. ${ }^{133}$ From May 1916 the NZWCA's Ladies' Committee became the main destination for the OSWPA's shipments of donated items for the 'British \& Belgian poor'. ${ }^{134}$ By November of that year, the NZWCA had established a dedicated 'Stores Committee' to deal with the distribution of incoming goods from patriotic organisations back in New Zealand. ${ }^{135}$ For New Zealand-based women's patriotic organisations, the NZWCA provided a solution to the difficulties of assessing potential aid recipients from a distance. As a February 1917 article on the OSWPA's shipments to the NZWCA noted, items were 'sent with no restrictions as to distribution': and 'used at the discretion of the ladies on Miss Mackenzie's committee. They are on the spot, and know

\footnotetext{
132 Elizabeth is pictured third from left. The woman to her left wears the VAD uniform of a Red Cross on the chest. ${ }^{133}$ Jean Burt to OSWPA branches, 5 August 1915, in OSWPA Scrapbook Album, AG-73, OSM. 134 OSWPA Minutes, 3 May 1916, AG-73, OSM.

135 Annual Report of the NZWCA, AJHR, H-40, 1917, 3.
} 
exactly what is required to make our men comfortable'. ${ }^{136}$ In relating to the distribution of gifts 'in kind and money' from New Zealand, the New Zealand High Commission noted that 'in every case care has been taken, by inquiries through official and other channels, that only organizations of good standing and individuals of unimpeachable character have been entrusted with gift goods from the Dominion...the greatest discretion has had to be exercised in choosing the recipients for the distribution of the gifts'. ${ }^{137}$

Beyond these more formal arrangements with organisations such as the NZWCA - themselves representing a form of upper-class network - the informal friendship and kinship webs of upper-class women provided important channels for the transfer of patriotic goods and funds between New Zealand donors and overseas charities. Several friends of the Stewart family took advantage of the family's patriotic society connections to seek donations of goods for their chosen war-related causes. Lillie Gillies approached Mary in 1915 for a donation to buy flannel for the Englishbased Belgian Soldiers' Clothing Committee, with which she was involved. Mary responded with a donation of $f^{20}$, per the OSWPA. ${ }^{138}$ In sending Mary her thanks, Gillies wrote: 'This clothing relief Co. have done such splendid work \& the Belgian Army heads have sent most grateful thanks; the whole army has been equipped with underclothing - \& thousands of idle Belgian women in Britain have been employed at the same time! ${ }^{139}$

New Zealand women's presence overseas, their role as a conduit of information of all sorts and the continued operation of their informal networks across distances can be illustrated in an appeal for donations towards a New Zealand field kitchen in 1916. Early that year the OPGWA received a request from Wellington Mayor J. P. Luke for donations towards a New Zealand field kitchen at the front. His letter also revealed the origin of the request: 'Mrs Sefton Moorhouse, in this city'. ${ }^{40}$ The OPGWA decided to seek further information on Mrs Moorhouse's personal credentials before agreeing to commit its funds, stating: 'Mrs Moorhouse is not known to any of our members, and

\footnotetext{
136 ‘Otago Women’s Patriotic Association’, Otago Daily Times, 10 February 1917, in OSWPA Scrapbook album, AG73, OSM.

137 Annual Report of the High Commissioner for New Zealand for 1916, AJHR, 1918, H-33, 11.

138 The OSWPA treasurer authorised, in March 1915, 'to send $£ 20$ Home for the purchase of flannel for shirts for the Belgian soldiers. Many of the refugees prefer to work for their own men if the material is provided'. Untitled newspaper clipping, OSDWC Minutes, 19 March 1915, AG-73, OSM.

${ }^{139}$ Lillie Gillies to Mary, 24 July 1915, MS-0985-033/001, HL.

140 John Luke to J. J. Clark, 1 February 1916, AG-113/212, HL.
} 
while willing to assist in any laudable object the Executive of this Association feels that before making a grant it should have before it the very fullest particulars'. ${ }^{141}$ These Luke supplied as follows: 'Mrs Moorhouse, who received the communication from England, is the wife of Mr Sefton Moorhouse, one of the leading citizens in Wellington, and who at the outbreak of war was appointed censor of all messages too [sic] and from New Zealand, so that her bona-fide is quite established'. She was also, he added: 'one of the principal workers in connection with the organisations we have in Wellington during the war, and in fact previous to the war breaking out. ${ }^{142}$ A letter enclosed with Luke's reply revealed the original source of the request as a letter addressed to Mrs Moorhouse from Mrs Florence Maclean, the wife of a wealthy Hawke's Bay station owner, Sir Robert Donald Douglas Maclean. Both Florence and Sir Robert Maclean were in England during the war, and were associated with a number of patriotic causes there. ${ }^{143}$ On this occasion, Florence Maclean had been approached by a minister, Reverend R. W. Doyle, to 'collect as much money as possible' for a fund to purchase 50 Motor Field Kitchens for the front lines. Florence Maclean's conversations with her own son Algernon, confirmed the urgency of this cause. ${ }^{144}$

Algy told me it was one of the terrible tragedies of the war, poor fellows left to die alone. He said when he was wounded and brought down to the first dressing station there was a young fellow next to him dying, he was quite conscious and out of pain and he wanted someone to talk to, as he had only a short time to live and felt so lonely, my son did what he could for him... This is only one of thousands of cases which Mr Doyle and others are trying to relieve by sending out a staff of helpers who will do all they can'. ${ }^{145}$

The OSPWA's response is not recorded, but the exchange illustrates the importance of upper-class women's personal networks as a means of verifying the credentials of potential recipients of aid from afar.

\footnotetext{
141 J. J. Clark to John Luke, 17 February 1916, AG-113/212, HL.

142 John Luke to J. J. Clark, February 1916, AG-113/212, HL. Sefton Moorhouse was a son of William Sefton Moorhouse, prominent Wellington lawyer and politician.

143 Sir Robert Donald Douglas Maclean and his wife lived in England during the war where they 'devoted all their energies to war work.' James Cowan, 'Famous New Zealanders - No. 20 - Sir Douglas Maclean - Settler and NationBuilder,' The New Zealand Railways Magazine 9, no. 8 (1 November 1934): 18-19, NZETC, URL: http://nzetc.victoria.ac.nz/tm/scholarly/tei-Gov09_08Rail-t1-body-d7.html, accessed 22 April 2013.

144 Algernon Maclean, the couple's only son died from war-related causes in Napier in 1923. Ibid., 18. Florence Maclean's references to her son as 'Algy' in her letters to Mrs Moorhouse suggests the two women were previously acquainted.

145 Lady Florence Maclean to Mrs Sefton Moorhouse, November 1915, AG-113/212, HL.
} 


\section{Conclusion}

This chapter has focused on the mobility of middle- and upper-class women who travelled overseas during the war in the hope of seeing soldier relatives or to fulfil a desire to 'do something' for the war effort. Those who travelled to be near soldier relatives were sometimes able to personally overcome the family distances of war, although the advantages to be gained through such travel had clear limits. As in the previous chapter, family formed the catalyst for a range of expressions of women's duty during the war, both in New Zealand and abroad. Such women's movements were increasingly restricted as the war progressed. Through introducing strict border controls targetting women (among other groups) governments worked explicitly to define the shape that women's wartime duty would take: it would be from afar that most New Zealand women supported the war effort. Despite such official resistance, New Zealand women comprised the core workers at institutions dedicated to the welfare of New Zealand troops overseas. The workers at such institutions performed the role of 'adoptive kin' by acting on behalf of soldiers' own relatives, and facilitating the flow of information back to soldiers' family members back home. ${ }^{146}$ A similar quasi-familial role was conducted on a larger scale by organisations such as the NZWCA. The flow of news, information and goods that these exchanges entailed - frequently facilitated by the existing friendship and family networks of upper-class women - demonstrated the ability of familial or quasi-familial bonds to break down the barriers between home and front. The next chapter presents a case-study of a particular women traveller and war worker, Elizabeth Stewart, and her efforts to come to terms with her grief over her husband's death.

146 Winter, Sites of Memory, Sites of Mourning, 30. 


\section{CHAPTER THREE}

\section{SPEAKING ACROSS THE BORDERLINE: INTIMATE CONNECTIONS AND DISTANCE IN THE LETTERS OF ELIZABETH STEWART.}

'Long before you get this, you will have heard, by cable, that our dear old George has gone'. With these words, Elizabeth Stewart wrote to her sisters-in-law Mary Downie Stewart and Rachel Armitage to relate the circumstances of their brother George Stewart's death. After negotiating her passage to Lemnos on the Galeka, Elizabeth had arrived in time to spend the final days of her husband's life at his bedside. ${ }^{2}$ For the first two days after Elizabeth's arrival, George had 'rallied', and his doctors had hopes for his survival, but the second night was a bad one, and George's condition did not improve at all the following day. On the morning of the fourth day, a Saturday, 'he gradually sank $\&$ at noon passed quietly away in my arms - so gently \& peacefully that I did not realize the last breath was gone until Sister told me! ${ }^{3}$ Writing the next day, Elizabeth sought to reassure George's two sisters that his death had been painless, without struggle or distress, and free of any premonition of the seriousness of his own condition. ${ }^{4}$ In the same letter, she recounted to his sisters how she had farewelled their brother for them, embracing him one last time on their behalf: 'Before leaving him I kissed his dear face for you both \& said goodbye "from Rachel \& from May". He looked his own dear self $\&$ his face, tho' very thin, had its sweet peaceful loving expression. ${ }^{5}$ On 24 November, accompanied by the hospital matron, Elizabeth attended George's burial in a little military cemetery beside a Greek Church, 'among all too many more who like him have

\footnotetext{
${ }^{1}$ Elizabeth to Rachel and Mary, 21 November 1915, MS-0985-041/001, HL.

2 Elizabeth acknowledged that it was 'only thro' General Russell' that this highly unusual allowance had been made and that 'it is a great concession on the part of the Authorities'. Elizabeth to Rachel, Mary, and Constance Herbert, 17 November 1915, MS-0985-041/001, HL.

${ }^{3}$ Elizabeth to Rachel and Mary, 21 November 1915, MS-0985-040/001, HL.

${ }^{4}$ Here, Elizabeth appears to have been motivated by a desire to comfort his siblings rather than convey an accurate account of his death. Contemporary observers acknowledged that dysentery patients suffered considerable discomfort. A New Zealand nurse working on a hospital ship off the coast of Lemnos during 1916 wrote 'We found the dysentery cases the most trying to nurse, how those poor men did suffer!' 'Letters From Our Nurses Abroad,' Kai Tiaki, July 1916, 141.

5 Elizabeth to Mary and Rachel, 21 November 1915, MS-0985-041/001, HL.
} 
given their lifes [sic] for their Country', and 'said goodbye for the last time to the earthly form of the best \& dearest of mates'. ${ }^{6}$

Drawing upon 114 letters that Elizabeth wrote to her husband's three siblings from 1915 until the 1920s, this chapter explores how Elizabeth negotiated her experience of grief over George's death, particularly focusing on the role that family relationships, mediated through correspondence, and her evolving religious beliefs, played in that process. The chapter's core narrative is organised around Elizabeth's attempts to sustain intimate connections across two forms of distance. The first type of distance, discussed in the first part of the chapter, was the geographical space that separated home in New Zealand from the front, or relative proximity of front, in Egypt, France and England. Here I argue that the letters Elizabeth exchanged with her husband's siblings were essential not only to sustaining their relationship after George's death, but to strengthening the affective ties between them after this event. In her intimate relationship with her husband's siblings, Elizabeth found an outlet for the feelings of grief she was unable to display outwardly in her professional life, discussed in the previous chapter. However, despite her work recreating 'home' for soldiers, Elizabeth's letters reveal her as deeply ambivalent about home and her prospects of return. For Elizabeth, maintaining a firm temporal division between her thoughts of home and 'the old life' and her present life as a war worker in a location geographically distant from that home, became a strategy by which she shielded herself from the full force of her grief over her husband. The second part of the chapter explores Elizabeth's attempts to bridge the transcendental divide between life and death, through her growing interest in the alternative religious movement of Spiritualism. At the same time as she attempted to keep George alive through her relationship with his siblings, Elizabeth intensified her efforts to connect with her husband across the borderlines of life and death.

${ }^{6}$ Elizabeth to Mary and Rachel, 21 November 1915, MS-0985-041/001, HL. 


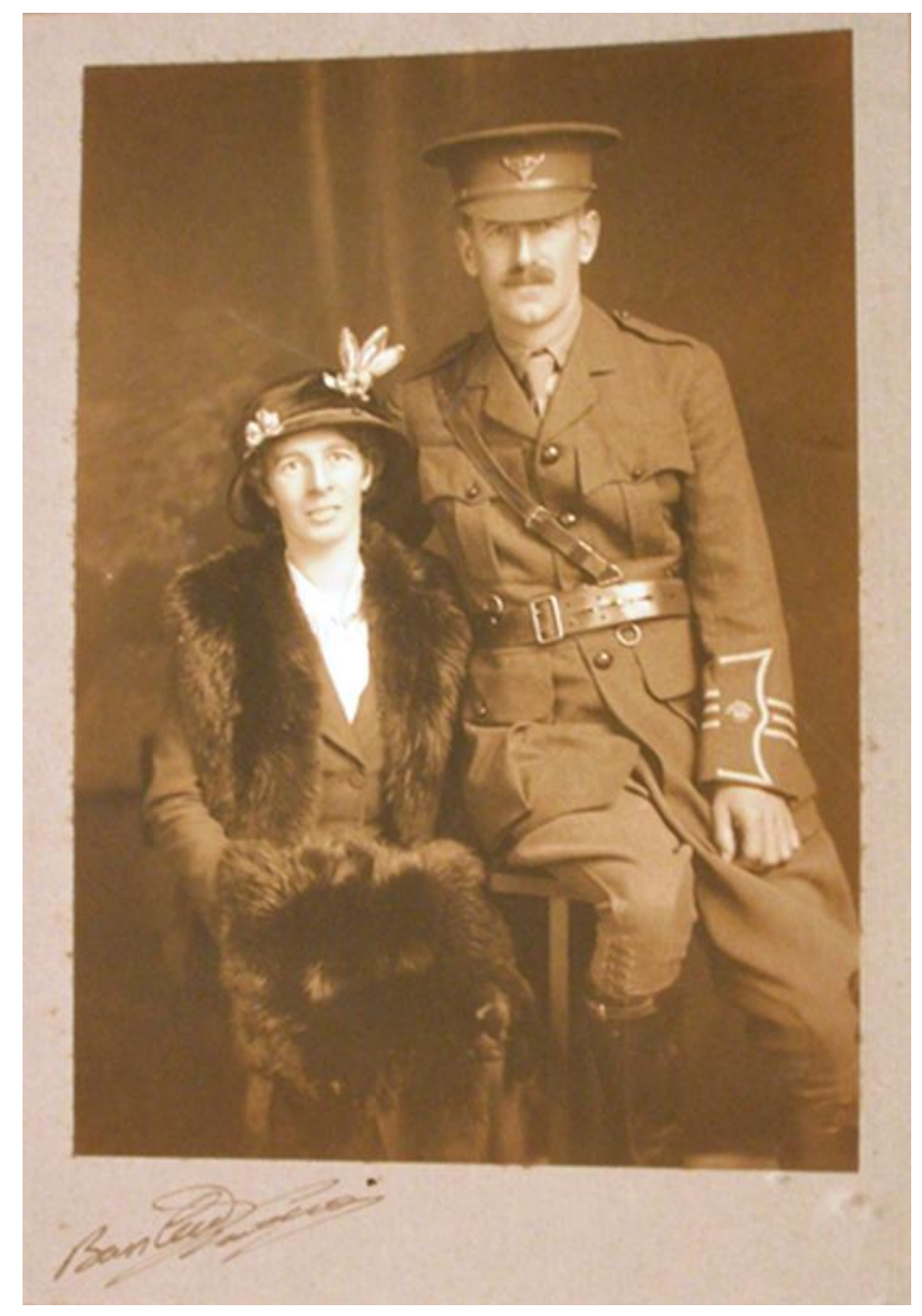

Figure 3.1: Studio portrait of George and Elizabeth Stewart, 1915

Source: MS-0985-057/264, HL.

Little is known about Elizabeth's educational background or life before her marriage to George, but her letters reveal her to be a fluent writer and highly competent in the conventions of letter writing, suggesting that she had attained a relatively high level of education. ${ }^{7}$ She was also prolific in her output of letters - a fact attested to both by the volume of her surviving correspondence, as well as the frequent references in her letters to others, sent and received. Like many authors of war-time letters, Elizabeth anticipated that her letters or the news contained therein would be shared among various members of the family, and this awareness shaped their content. 'I know you exchange news with others so you should all get most of what there is thro' one letter or

\footnotetext{
${ }^{7}$ Elizabeth's father John Francis Herbert's period of service as president of the Lawrence Athenaeum suggests that he valued education highly. 'Lawrence Athenaeum and Mining Institute,' Tuapeka Times, 23 February 1895, 3.
} 
another.' ${ }^{8}$ On average, over the period between August 1915 and January 1919, Elizabeth sent a letter per fortnight, and sometimes up to five letters per month, to one or more of her husband's siblings. During this period only one month, March 1918, had no letters, suggesting that the archival holdings for Elizabeth's letters during this period are fairly complete. Only Elizabeth's letters have survived, and thus only one side of her conversation with George's siblings is now available to us. Her letters furnish evidence that she also exchanged letters with other correspondents during the war, including with her own relatives, but none of these survive. Of course, even among this highly literate family, some family members were more dedicated to writing than others. In one 1917 letter, Elizabeth complained that she had not received a single letter from her brother Dr William Herbert in the two years since she and George had left New Zealand. Sibling relationships did not necessarily translate into regular correspondence; war-time separation did not always engender a need or desire to write.

Scholars of epistolarity emphasise the importance of the 'spaces' afforded to individual letter-writers for writing, as well as the material features of the letters themselves. ${ }^{10}$ Both are revealing in the case of Elizabeth Stewart's letters. The writing of letters formed a regular part of Elizabeth's daily routine, although the time she set aside for letter-writing was frequently impinged upon by the demands of her war work and other daily tasks. Her letters were often written late at night, on Sundays, or in opportunities snatched during work days - the insertion of additional dates throughout a letter indicating it was written over several days, or over a period of a week. With regard to spaces of writing, many of Elizabeth's letters show signs of having been written during her breaks from work, during which, if she remained on the premises, she was subject to frequent interruptions. Some of the spaces in which Elizabeth wrote almost certainly contributed to the disjointed nature of many of her letters. In a March 1916 letter, for instance, she apologised for the standard of her letter, stating 'I'm afraid this is a very silly sort of letter but I'm writing now at the British Soldier's Cafe \& am suffering innumerable interruptions. ${ }^{11}$ And, in December 1917, she wrote: 'I'm afraid this letter is getting a very "on active service" look - which means "grubby \& crushed"

\footnotetext{
8 Elizabeth to May, 15 May 1916, MS-0985-050/002, HL. Martyn Lyons notes that it was usual for the letters home of French soldiers to be intended for multiple members of a family. See Martyn Lyons, Reading Culture and Writing Practices in Nineteenth-Century France (Toronto: University of Toronto Press, 2008), 186.

${ }_{9}^{9}$ Elizabeth to Rachel, 22 August 1917, MB-391-4/26, MBL. She did not count a letter of condolence she received from her brother William. See W. E. Herbert to Elizabeth, 1 December 1915, MS-0985-033/002, HL.

${ }^{10}$ Stanley, 'The Epistolarium,' 212.

11 Elizabeth to Rachel, 28 March 1916, MS-0985-041/002, HL.
} 
but it is subjected to many interruptions \& is written at odd minutes'. ${ }^{12}$ Generally Elizabeth wrote on either plain letter paper, or on the letter paper provided by hotels or the Soldiers' Clubs and Hospitals at which she volunteered. The letter paper she wrote on thus gave clues as to her present activity and movements. For instance, mid way through her letter of 23 March 1916, she switched from the paper provided by the Grand Continental Hotel, Cairo, where she started her letter while waiting for Agnes to have her hair shampooed at the hotel, to the letterhead of the British Soldiers' Cafe, Cairo. She commented: Now I am "on duty”, at the British Cafe (as you will discover by the change of paper) $\&$ as things are quiet for the moment will try to finish your letter'. ${ }^{13}$ Shortly after, she brought her letter to a close, citing interruptions.

Letters had their limitations as forms of communication. Elizabeth's letters contain regular complaints at the delay or disappearance of mail. She wrote to William in December 1917, 'In your letter you did not mention having received any letters from me - I have written several times but I am afraid a great many letters are lost now adays! ${ }^{14}$ In ordinary times, mail took 31 days to travel the distance between London and New Zealand. But during war-time delivery times increased while hazards to shipping grew. ${ }^{15}$ As a way of bypassing such delays, urgent news was conveyed through the wireless telegraph network. George's siblings in New Zealand first learned of their brother's death through a cable from Elizabeth with the plainly worded yet evocative message: 'George passed gently away in my arms'. However, cables were costly, and even this affluent family used them sparingly. ${ }^{16}$ Wartime censorship was also a factor in the case of wartime cables and letters. ${ }^{17}$ In a December 1915 letter, conveying the news of a recent British decree that all letters leaving Egypt be subject to censorship, Elizabeth commented on the possible effects of censorship on her letter writing. The awareness that her letters would be read not only by their intended recipients but by an outsider, she wrote, would inhibit her: 'I won't be able to write quite so freely - Not that I was

\footnotetext{
12 Elizabeth to William, 10 December 1917, MS-0985-007/004, HL.

13 Elizabeth to Mary, 23 March 1916, MS-0985-050/002, HL.

14 Elizabeth to William, 10 December 1917, MS-0985-007/004, HL.

15 Howard Robinson, A History of the Post Office in New Zealand (Wellington: Government Printer, 1964), 188. Some mail boats become the casualties of German submarine warfare during the war. 46 bags of letters intended for New Zealand were lost when the Arabic was sunk by German submarine on 19 August 1915, while 926 bags of mail for New Zealand were destroyed when the Mongolia was sunk off Bombay in January 1917. Report of the Postal and Telegraph Department 1915-16, AJHR, 1916, F-1, 7; Report of the Postal and Telegraph Department 1917-1918, AJHR, 1918, 7.

16 In September 1915 the Postmaster General raised the rates for a telegram of 12 words (including address) from 6d to 8d. Robinson, A History of the Post Office, 195. Exceptions were made for telegrams of inquiry from the relatives of NZEF members officially reported wounded or ill, who were permitted three free telegrams of inquiry. Report of the Post and Telegraph Department 1914-15, AJHR, 1915, F-1, 4.

${ }^{17}$ For the censorship of incoming cables into New Zealand see Robinson, A History of the Post Office, 194.
} 
ever able to give you any war news; but one does not write of one's personal affairs so naturally if other than the one written to is to read it'. ${ }^{18}$ However, if awareness of the censor deterred Elizabeth temporarily, it does not appear to have affected her ability to write openly and candidly of her feelings in the long term. ${ }^{19}$ Furthermore, such restrictions did not apply during her stays in France and England, where the civilian mail was not subject to censorship. ${ }^{20}$ Despite their limitations, as Kate Hunter argues in the case of soldiers' correspondence, such letters were 'efforts to maintain emotional proximity in the face of physical separation'. ${ }^{21}$

Prior to George's death, the letters Elizabeth wrote to his siblings served several functions: to describe their lives in Egypt and, after George's departure for Gallipoli, to relay back to his family the latest reports of him taken from his own letters or gleaned from returned military contacts. Elizabeth considered the latter source of information to be more reliable than George's own letters, in which he invariably described himself as 'cheerful'. After George's death, Elizabeth's letters to his siblings necessarily took on new functions, reflecting their changed relationship. Elizabeth's first priority after George's death was to convey to his siblings as detailed an account as possible of the events surrounding his illness, death and burial. Her proximity to the front made the Stewart family's experience of bereavement fundamentally different to that of most New Zealand families, most of whom learned of the circumstances of their loved one's death through an intermediary, if at all. ${ }^{22}$ By contrast, Elizabeth was able to satisfy herself and George's family that her husband had received the best medical care and every attention necessary for his comfort. 'I am allowed to be with George all the time', she wrote three days before his death: 'it is something to be able to sit beside him \& see the flies don't annoy him \& do any other little thing I can'. ${ }^{23}$ While the cultures of death are class-bound, the ideal of dying surrounded by loved ones constituted a 'good death' for people of all social backgrounds. ${ }^{24}$ The policy of most combatant nations of not

\footnotetext{
18 Elizabeth to May and Rachel, 31 December 1915, MS-0985-041/001, HL.

${ }^{19}$ In her letters immediately following this decree Elizabeth appears acutely aware of the censor - expressing the hope that certain criticisms about the state of military organisation in Egypt would meet the censor's approval. However, this self-consciousness soon disappeared from her letters.

${ }^{20}$ In France, some soldiers circumvented censorship (and acted in contravention of military regulations) by depositing mail in civilian mailboxes, which were not subject to censorship. Hanna, 'A Republic of Letters,' 1356. Some British soldiers arranged to have men going on home leave to take letters with them as a way of evading the military censor. See McCartney, Citizen Soldiers, 91.

${ }^{21}$ Hunter, 'More Than An Archive of War,' 339.

22 Winter, Sites of Memory, Sites of Mourning, 35-44.

23 Elizabeth to Rachel, Mary and Constance Herbert, 17 November 1915, MS-0985-041/001, HL.

${ }^{24}$ Before the war, working class deaths typically took place in the home. Keeping vigil over the dying 'ease[d] the distress of impending death, both for the dying and their carers'. Julie-Marie Strange, 'She Cried a Very Little': Death, Grief and Mourning in Working-Class Culture, c. 1880-1914,' Social History 27, no. 2 (May 2002): 146. The 'ideal'
} 
repatriating their war dead meant that Elizabeth's opportunity to attend her husband's burial was also unusual, and marks out her experience of bereavement as highly uncommon among dominion families. ${ }^{25}$

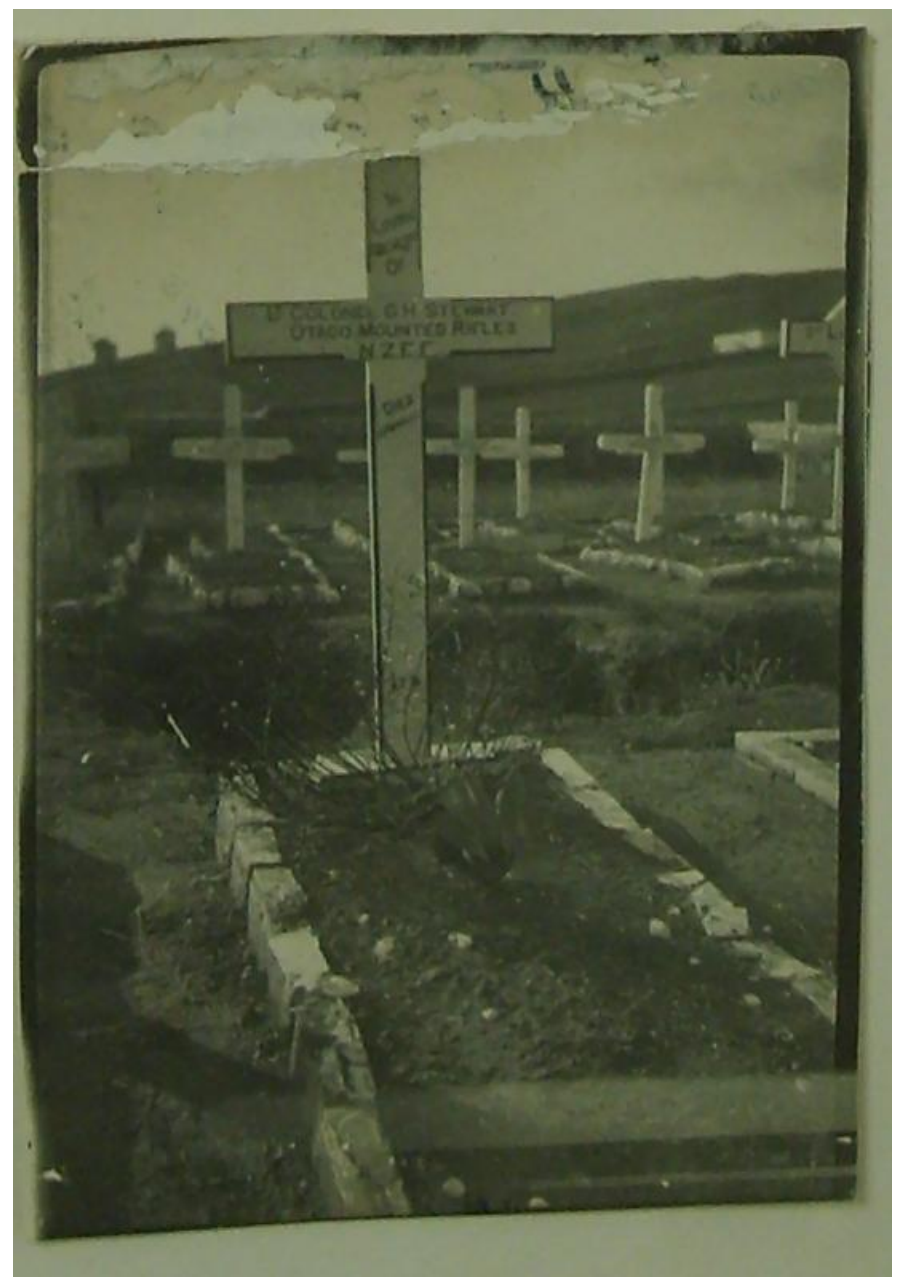

Figure 3.2: George Stewart's grave, Lemnos

Source: MS-0985-033/008, HL.

The fact that all the participants in this epistolary exchange continued to write after George's death suggests that they placed some value on continuing their relationship after the initial details of George's death and burial had been conveyed. One of the reasons Elizabeth valued her correspondence with George's siblings was the

middle-class death also took place at home surrounded by loving family: hospitalisation for the dying did not become common among the middle classes until the interwar period. Jalland, Changing Ways of Death, 200-203; __ , Death in the Victorian Family, 26.

${ }^{25}$ Ziino, A Distant Grief. See also Audoin-Rouzeau and Becker, 14-18, 215. Only the United States military repatriated their war dead during the First World War. 
opportunity it provided to share her feelings with others who felt the same deep sense of emptiness at George's death. As she sympathised with Rachel in a June 1916 letter, 'How well I know that heaviness of spirit you write of, when everything seems a hopeless blank \& as tho' it is impossible to go on another step! ${ }^{26}$ As she explained to Rachel and Mary in January 1917, Elizabeth considered that their mutual love for George itself constituted a bond between them. '[M]any thanks for your letters which helped more than I can say - the Fact that you both care so much \& that he was dear to you \& you to him draws us all very near to each other. ${ }^{27}$ Thus the bonds of affection between Elizabeth and her husband's siblings, grounded in their shared love for George, were, for Elizabeth, capable of overcoming the geographical distance between them.

Elizabeth was aware of social expectations that the bereaved should not visibly succumb to grief, but should maintain an outwardly stoic appearance. While she continued her hospital work after George's death, Elizabeth revealed to his siblings that she struggled to hide her inner turmoil from her patients and the other staff. She wrote in January 1916, 'I'm trying to keep as brave a face as possible to the outside world but there's no use pretending to those who know that my burden is almost too heavy to bear \& that it is only because I know that it is God's will \& because my dear one is very near me helping me all the time with his wonderful love that I am able to go on quietly with my work'. ${ }^{28}$ Elizabeth's letters to George's siblings formed a space in which she could reveal her true self and feelings, free from the pressure to conform to social or professional expectations of behaviour. Like the soldiers described by the British historian Michael Roper, emotional connections with home via correspondence were key to Elizabeth's ability to endure the stresses of war. ${ }^{29}$

For Elizabeth, letters were a source of connection with home and of her former life with George. Yet, as her letters make clear, her life in New Zealand before the war began to recede in comparison with the immediate realities of her life as a war worker. Letters helped to close up this gap. She wrote in a 1918 letter: 'When, as sometimes happens, there are weeks of waiting between the mails I seem to lose touch with all that has been \& it becomes part of another existence - Then come your letters with all their loving thought $\&$ interest $\&$ link me once again with the dear precious days when all was

\footnotetext{
${ }^{26}$ Elizabeth to Rachel, 28 June 1916, MS-0985-041/002, HL.

27 Elizabeth to Rachel and Mary, 17 January 1916, MS-0985-041/002, HL.

28 Elizabeth to Rachel and Mary, 3 January 1916, MS-0985-041/001, HL.

29 Roper, The Secret Battle.
} 
so full of joy \& promise'. ${ }^{30}$ But, at other times, her sense of detachment from home and her former life left her with little energy for letter writing. 'I have been feeling very uncommunicative lately,' she wrote in October 1918, 'so far away from, \& finished with, the old life \& all it contained'. ${ }^{31}$ Other letters also reveal her as strongly ambivalent about 'home' and the prospect of her return there. In one 1918 letter to Rachel, she revealed that the loss of George rendered her effectively 'homeless'. In writing of her 'aching longing \& "home sickness", she added 'and by "home" I mean George for with out [sic] him no place is home just as with him any place would have been'. ${ }^{32}$ Similarly, she wrote in October 1918, in connection to her return to New Zealand, 'altho' one longs to see one's friends one shrinks from accentuating the pain \& lonliness [sic] in one's heart by returning to the old life - with the sun taken out of it! ${ }^{33}$

Elizabeth's letters contain many references to the value she placed on her voluntary war work as a form of distraction from her grief. ${ }^{34}$ While historians have recognised the importance that immersing oneself in one's work had for men coping with the loss of a loved one, the solace of work has been a lesser part of scholarship on women's grief. ${ }^{35}$ Unlike other widows, the earlier death of their son meant that Elizabeth could not take comfort in children. ${ }^{36}$ Writing a month after George's death, shortly before Christmas 1915, Elizabeth explained to William that Christmas 'will be a sad one for us all' but '[f]ortunately for me we are going to be very busy at the hospital trying to make things as pleasant as possible for the boys there... Some times I wonder if I can stand it but keeping busy is the easiest way thro' \& I know it is the way my dear old boy would have me act. ${ }^{37}$ And, she reflected in January 1918, 'I feel that I cannot pity anyone for having plenty to do these days - the people I am really sorry for are

\footnotetext{
${ }^{30}$ Elizabeth to Rachel, 17 June 1918, MB-391-4/26, MBL.

31 Elizabeth to Rachel, 11 October 1918, MB-391-4/26, MBL.

32 Elizabeth to Rachel, c. 1918, MB-391-4/26, MBL.

33 Elizabeth to Rachel, 11 October 1918, MB-391/4/26, MBL.

34 William's letters contain similar sentiments. He wrote to Rachel on 12 December 1915 from military camp in Tauherenikau: 'We have had a heavy week marching \& working all day \& sometimes at night... However, I welcome it as it keeps me absorbed \& it is only on Sundays that I get time to think'. William to Rachel, 12 December 1915 , MS-0985-039/002, HL.

35 Jalland, Death in the Victorian Family, 252. Bruce Scates' work forms an exception. See Scates, 'The Unknown Sock Knitter,'39-40.

36 Jalland, Death in the Victorian Family, 243. The consolations of children are also mentioned in reference to men's grief. When Wellington woman Morna Johnston, nee Fell, died of illness in Egypt in 1915, her grieving husband General Erl Johnston was noted to 'have no child to console him in his grief. 'Social Gossip,' Free Lance, 23 December 1915, 14

37 Elizabeth to Rachel and Mary, 21 December 1915, MS-0985-041/001, HL.
} 
those who cannot - or don't want to - work - I am sure that I am far from being the only one whose work has been their salvation! ${ }^{38}$

Elizabeth treasured the letters she had received from George during his time on Gallipoli and Lemnos as another enduring link with her husband. While the letters themselves do not survive, it is possible to glean something of their contents and their ongoing significance to Elizabeth through the references to them in her own letters. While George was away at the front, he and Elizabeth penned letters to each other daily, although lengthy postal delays meant that their letters frequently took a fortnight to arrive: 'We were often two weeks without one ('tho we wrote every day) \& then would perhaps get several together \& I know there are many I haven't got yet. During the last three days he was in camp George got 15 of mine. Fortunately he acknowledged the last at once $\&$ his last letter to me is full of the joy that mine were to him' ${ }^{39}$ In spite of their separation, Elizabeth later recalled, the two of them were so closely attuned that they often found themselves writing to the other on the same topic on the same day, 'our thoughts...running together even tho' we were all those miles apart'. ${ }^{40}$ American historian Karen Lystra argues that nineteenth-century lovers regarded love letters as the nearest thing to 'actual conversations' with their lovers, for their eyes only, and guarded them assiduously from outsiders. ${ }^{41}$ This was certainly so in the case of Elizabeth's letters from George. Unlike letters she received from others of her regular correspondents, she did not forward his letters on to his siblings, nor divulge anything but a small portion of their contents. References to reading George's letters in Elizabeth's own letters suggest that she revisited them frequently after his death. She wrote in January 1916 'George's letters are a source of great strength \& comfort to me - he always seemed to write just what I needed'. ${ }^{42}$ A few months later she explained that George's letters were 'what I feed my heart on now \& the joy beyond all pains, that I have to carry on thro' all eternity with me. ${ }^{43}$

In a June 1916 letter, Elizabeth expressed her belief that, of all human emotions, 'only love counts - true, pure love that rises above the less worthy emotions'. ${ }^{44}$

\footnotetext{
${ }^{38}$ Elizabeth to Rachel, 17 January 1918, MB-391-4/26, MBL.

${ }^{39}$ Elizabeth to Mary and Rachel, 10 December 1915, MS-0985-041/001, HL.

40 Elizabeth to Rachel, 28 March 1916, MS-0985-041/002, HL.

${ }^{41}$ Karen Lystra, Searching the Heart: Women, Men, and Romantic Love in Nineteenth-Century America (New York: Oxford

University Press, 1989), 4.

42 Elizabeth to Mary and Rachel, 3 January 1916, MS-0985-041/001, HL.

43 Elizabeth to Rachel, 28 March 1916, MS-0985-041/002, HL.

${ }^{44}$ Elizabeth to Rachel, 28 June 1916, MS-0985-041/002, HL.
} 
Elizabeth believed romantic love between husband and wife to be one of the most intense forms of love, as well as a sacred bond in the Christian sense. ${ }^{45}$ In a March 1916 letter Elizabeth noted that while she was worried for William and for her own brother Alfred, both of whom were then engaged in fighting on the Western Front, her feelings of anxiety on their behalf were in quite a different way to [those] with which one yearns over one's mate. ${ }^{46}$ Elizabeth felt the death of her brother James 'Jim' Laidlaw Herbert, who was killed in action at the Somme on 30 September 1916, as a physical blow: 'You know it feels to have cold water dashed in one's face - one gasps \& shudders for a moment before one's breath comes naturally again! ${ }^{47}$ Nevertheless, the loss of her brother Jim never formed the same central preoccupation in Elizabeth's writings and spiritual reflections as did that of her husband.

Even within the category of married love, Elizabeth believed that few couples attained the same depth of union as she and George. She wrote to Rachel in March 1916, You seem to have a clearer insight into the sacredness of the union between George \& me - we weren't just married people in the ordinary sense - it was our souls that were mated. ${ }^{48}$ And, in a letter to May written the following month, April 1916, Elizabeth explained her belief that 'No one can ever know what joy was ours for only those who experience these things have any idea, \& no others were ever quite such "really truly" mates as we were - tho', of course I know lots think they are!! ${ }^{49}$ Victorian lovers, writes Lystra, 'were taught to reserve their truest or best or most worthy expressions for a single beloved'. ${ }^{50}$ Similarly, Elizabeth observed 'I often think how wonderful it is that of all who know \& love him - I should be the one who really knows - to whom he gave his very self. ${ }^{51}$

What Elizabeth believed to be her unique bond with George had consequences not only during their time together on earth, but for the afterlife. As she explained to Rachel in May 1916, both she and George had believed that the union of their two souls was such that their bond would be eternal: 'we both knew that our souls were mated \&

\footnotetext{
${ }^{45}$ Leonore Davidoff writes of nineteenth-century and early-twentieth marriages that 'On being married, a man and woman were believed to become 'one flesh', a tie for life that could not be undone and resonated beyond death'. Davidoff, Thicker Than Water, 61.

46 Elizabeth to Rachel, 28 March 1916, MS-0985-041/002, HL.

47 Elizabeth to Mary and Rachel, 31 October 1916, MS-0985-041/002, HL. Jim Herbert left behind a wife, Evelyn (Gladys) and their daughter, Evelyn Barbara, born February 1915.

48 Elizabeth to Rachel, 28 March 1916, MS-0985-041/002, HL.

49 Elizabeth to Mary, 12 April 1916, MS-0985-033/003, HL. Some nineteenth-century American lovers shared similar convictions about the unique nature of their bonds. See Lystra, Searching the Heart, 201.

50 Ibid., 7.

51 Elizabeth to Mary and Rachel, 30 January 1916, MS-0985-041/002, HL.
} 
that even as they had found each other here they will elsewhere \& go on thro' all eternity together'. ${ }^{52}$ The belief that George's spirit had passed on to Heaven formed one of Elizabeth's greatest consolations after George's death. Her descriptions of the after life conform with the Victorian notions of heaven as place of family reunion. ${ }^{53}$ The idea of heaven as a tangible place where individuals would be readily recognisable and loved ones reunited, is clear in a January 1916 letter of Elizabeth's: '[O]ften I think of the joy of reunion - nothing seems to matter now but trying to "win thro" so that his smile of welcome will be full of gladness when we too have crossed the border. ${ }^{54}$ Their present period of separation, she explained in 1918, was brief in comparison to the prospect of spending eternity together in Heaven: 'altho' the days are long \& empty, after all this life at longest is only as one day in eternity I often think of how George said to me before he went to Gallipoli “Always remember Girl, that if I don't come back the time will soon pass \& I will be waiting for you"”. ${ }^{5}$

While Elizabeth's foremost hope in the years following George's death was that she herself would soon join her husband in Heaven, this period was also marked by the increasing intensity of her efforts to communicate with her husband in spirit form. ${ }^{56}$ Successful spirit communication with George, Elizabeth believed, would be contingent upon several factors. The first of these involved Elizabeth's own spiritual evolution to the point that she was equipped to receive George's messages. In one letter she explained, 'I know that when I learn how I will be able to get into close communion with my mate. I know I mean as much as ever to him \& that our love must always respond to the call of each other $-\&$ I do believe that some twin souls can converse while one is still here - Perhaps I may be too "material" but I am going to try \& learn how'. ${ }^{57}$ Elizabeth also believed that George's messages would only reach her under perfect conditions: 'those conditions which, I believe, are alone necessary to enable him to reveal his nearness, \& his unbroken connection with \& affection for me'. ${ }^{58}$ Increasingly she came to associate this ideal atmosphere with her return to their home of 'Westwood', Crookston. As she wrote in December 1918: 'Since the signing of the Armistice - which has unsettled everything \& everybody, I, too, have had a great

\footnotetext{
52 Elizabeth to Rachel, 19 May 1916, MS-0985-041/002, HL.

53 Jalland, Death in the Victorian Family, 266-67, 271.

${ }^{54}$ Elizabeth to Mary and Rachel, 17 January 1916, MS-0985-041/002, HL.

55 Elizabeth to Mary, 3 January 1918, MS-0985-050/002, HL.

${ }^{56}$ She wrote in 1918 'when my work is finished I will be called on \& my dear ones [sic] smile of welcome will be the first thing I am aware of in my new home - I feel as tho' I shall waken up looking for it!' Elizabeth to Rachel, c. 1918, MB-391-4/26, MBL.

${ }^{57}$ Elizabeth to Rachel, 14 January 1917, MB-391-4/26, MBL.

58 Elizabeth to Rachel, 5 December 1918, MB-391-4/26, MBL.
} 
longing to go home tho' I occassionally [sic] gasp when a flash of realization of what it will mean, comes to me - But I know that George himself will see me thro' \& that in the full realization of my lonliness [sic] he will be given power to reveal his nearness. ${ }^{59}$ Despite her ambivalence towards home and the prospects of return, Elizabeth increasingly came to believe that the couple's spirits would only be reconciled at Westwood. 'I often think that it will be in that dear home of which he loved every inch that George will first get a definite message thro' - He always wanted all the important things to happen at home! ${ }^{60}$

While Elizabeth's conviction that she would join George in Heaven fell within the spectrum of mainstream Christianity, her conviction that the living could communicate directly with the dead was clearly beyond the boundaries of what most Christians believed. Elizabeth's exchange on religion with a soldier patient at Brockenhurst, related in a 1918 letter, is indicative of her positioning of her religious views in relation to other Christians. In the letter, Elizabeth recalled how she had struck up a conversation with a soldier in one of her wards, the topic of which soon turned to religion. Her description of the incident makes clear the divergence of the soldier's views from her own. 'It is a long time since I have come in touch with the hard \& fast "Conversion or damnation" type of christian \& I must confess it was rather a shock! But I realized the danger \& trod warily - putting forward only big general truths as food for reflection \& enlightenment, \& leaving details alone - Here was a mind absolutely unfitted to receive of the glorious fields of understanding on the outskirts of which I am groping. ${ }^{61}$ Her responses to the soldier's beliefs indicates her acceptance of the Universalist doctrine, shared by many Spiritualists, that a 'God of Love' would not condemn any soul to eternal damnation and that all human souls would eventually progress to Heaven. ${ }^{62}$ As Elizabeth wrote to William, the more the soldier attempted to 'impress on me the awfulness of the wrath of God', the more she insisted on the power of God's love: "As I told the boy I had no time to think of the "wrath" because I couldn't get beyond, above, or outside the "love of God", \& that to me, all that

\footnotetext{
${ }^{59}$ Elizabeth to Rachel, 5 December 1918, MB-391-4/26, MBL.

60 Ibid.

${ }^{61}$ Elizabeth to William, 9 February 1918, MS-0985-007/004, HL.

62 Universalist churches believed that an 'all-good and all-powerful God saves all souls'. Ann Lee Bressler, The Universalist Movement in America, 1770-1880 (Oxford: Oxford University Press, 2001), 6. Many American Universalists were drawn to 'spiritual sciences' such as spiritualism, phrenology and mesmerism during the nineteenth century. See ibid., especially chapter five. Universalism was also a 'characteristic feature of Spiritualist discourse' in nineteenthcentury Australia. Alfred Gabay, Messages From Beyond: Spiritualism and Spiritualists in Melbourne's Golden Age, 1870-1890 (Carlton: Melbourne University Press, 2001), 6.
} 
mattered was that wonderous Love'. ${ }^{63}$ The reactions of other Christians to Elizabeth's beliefs are also indicative of the degree to which they had diverged from Christian orthodoxy by the latter years of the war. Miss Wilson, a former colleague of Elizabeth's at Brockenhurst met Mary Downie Stewart at a dinner party in 1919, and the two women soon realised their mutual acquaintance in Elizabeth. While admitting that Elizabeth had an 'extraordinary personality' Miss Wilson told Mary that she did not approve of her 'spiritualist research', stating 'I am inclined to fear she will lose all thought of her Creator in her wish to get in touch with her husband, ${ }^{64}$

By 1917, Spiritualist beliefs seemed 'common sense' to Elizabeth, but this had not always been the case. ${ }^{65}$ As she wrote in October of that year, 'It is not so very many years ago since all these ideas looked "dangerous" to me \& now they are so simple \& common sense that I wonder how anyone should hesitate over them or what they build on without them! ${ }^{66}$ Neither Elizabeth's family background nor her marriage provide any clues as to the development of her Spiritualist beliefs. Elizabeth was raised in a devout Anglican family, while George remained committed to the Presbyterian faith of his upbringing until his death. ${ }^{67}$ Elizabeth did not convert upon her marriage, and from her own accounts of their relationship, it appears that George did not dictate to her on matters of religion. Rather, the pair engaged in a two-way debate on religious topics. As she reflected in 1917 'He taught me so much - \& learned so much from me too, - for tho' he believed himself to be so orthodox; \& couldn't make up his mind what I was we only saw the same truth from a different angle \& expressed it in other words' ${ }^{68}$ While it is not possible, based on extant evidence, to pin-point the precise time at which Elizabeth's interest in Spiritualism emerged, it is clear that it predated not only George's death, but the war itself. Several of Elizabeth's letters allude to conversations with George at Westwood on the topic of her 'new religion', of which he disapproved. ${ }^{69}$ The death of her mother in 1912 and the death of their baby in 1913 present two possible explanations for the timing of its emergence, but her letters do not provide sufficient

\footnotetext{
${ }^{63}$ Elizabeth to William, 9 February 1918, MS-0985-007/004, HL.

64 Mary to Rachel, c. 1919, MS-0985-040/006, HL.

65 Anna Stout, wife of Prime Minister Sir Robert Stout, was the most famous New Zealand adherent of Spiritualism. Both the couple were family friends of the Stewart's, Robert Stout having trained in their father William Downie Stewart's law practice.

66 Elizabeth to William, 14 October 1917, MS-0985-007/004, HL.

${ }^{67}$ Elizabeth's mother Agnes Herbert (nee Dewe) was a committed Anglican and her father John Francis Herbert was an office-bearer in the All Saints Anglican church at Tapanui. See Frederick Miller, Beyond the Blue Mountains: A History of the West Otago District (Dunedin: Otago Centennial Publications, 1954), 166; obituary, 'Mrs J. F. Herbert nee Dewe' in MS-0985-054/001, HL.

68 Elizabeth to William, 14 October 1917, MS-0985-007/004, HL.

${ }^{69}$ Ibid. Elizabeth's acceptance of universal salvation placed her at odds with the Calvinist tenets of her husband's Presbyterian faith.
} 
evidence to corroborate this. Elizabeth's home province of Otago formed the epicentre of Spiritualist activity in New Zealand during the religion's peak in the 1870s and 1880s. Spiritualists and their detractors debated the subject in newspapers and public lectures, and well-known adherents of the faith such as Anna Stout, wife of Robert Stout, New Zealand Premier from 1884 to 1887 , lent their beliefs publicity and credibility. ${ }^{70}$ While this background may have provided Elizabeth with her initial exposure to Spiritualist ideas, her ongoing engagement with Spiritualism was shaped by the global transferability of print culture. ${ }^{71}$

Elizabeth derived most of her information on Spiritualism from books. Her reading choices demonstrate her agency to pick and choose those authorities on Spiritualism whose work she found most convincing and inspiring, while rejecting others. In this way Elizabeth was, as Sarah Williams has written of other religious women, both 'maker' and 'inheritor' of religious cultures. ${ }^{72}$ The rise of Spiritualism in the nineteenth century was part of a wider challenging of the religious orthodoxies of the established churches, and its adherents often had links to other radical movements of the time. ${ }^{73}$ Elizabeth was also drawn to Theosophy, another expression of this challenge to traditional religion. ${ }^{74}$ Both Elizabeth and Rachel owned copies of the Theosophical title What We Shall Teach, and Elizabeth drew similar solace from the book as she did from Spiritualist works. ${ }^{75}$ She wrote in 1918 'There is something so strong \& comforting about it - so beautiful in its conception of the Love at the back of all things, that it appeals to me very strongly - It was given to me by what I call a "special messenger" - one of those people who just "happen along" with just the very help you

\footnotetext{
${ }^{70}$ Shaun Broadley, 'Spirited Visions: A Study of Spiritualism in New Zealand Settler Society, 1870-1890,' (PhD thesis, University of Otago, 2000); Robert Ellwood, Islands of the Dawn: The Story of Alternative Spirituality in New Zealand (Honolulu: University of Hawai'i Press, 1993), chapter 2.

${ }^{71}$ Ellwood describes Spiritualism as the first 'significant religious movement to engage public attention primarily through the agency of modern mass media', as new forms of transportation 'carried expeditiously and in relative ease its lecturers and express-shipped books and magazines to far corners of the globe, including New Zealand'. Ellwood, Islands of the Dawn, 20. For New Zealanders' participation in the global traffic of print culture more broadly see Susann Liebich, 'Connected Readers'.

${ }^{72}$ Sarah C. Williams, 'Victorian Religion: A Matter of Class or Culture?,' Nineteenth Century Studies 17 (2003): 13-17.

${ }^{73}$ For the links between Spiritualism and the feminist movement, see Ann Braude, Radical Spirits. Spiritualism and Women's Rights in Nineteenth-Century America, 2nd ed. (Bloomington: Indiana University Press, 2001).

${ }^{74}$ For the crossovers between Theosophy and the British suffrage movement see Joy Dixon, Divine Feminine: Theosophy and Feminism in England (Baltimore: John Hopkins University Press, 2001). It is not surprising that feminists were drawn to both Spiritualism and Theosophy. Both religions offered women spiritual equality with men, permitted women to hold leadership positions, and endorsed progressive causes such as women's rights. See Braude, Radical Spirits, 3; Dixon, Divine Feminine, 5-9. See also Alex Owen, The Darkened Room. Women, Power, and Spiritualism in Late Nineteenth-Century England (London: Virago Press, 1989).

${ }^{75}$ Curuppumullage Jinarajadasa, What We Shall Teach, (Madras: Theosophical Publishing House, 1915). The

Theosophical Society was founded in 1875 in New York, but soon afterwards moved its base to Madras (present-day Chennai) in India. As theosophy 'claimed to unify all religious traditions' many members embraced theosophy while continuing to identify with other religious traditions such as Christianity or Buddism. See Dixon, Divine Feminine, 3-4. For theosophy in the New Zealand context see Ballantyne, Webs of Empire, 91-93; Ellwood, Islands of the Dawn, chapter
} 4. 
need \& when you most need it - \& then are gone'. ${ }^{76}$ For Elizabeth, the pursuit of theological questions on the nature of life after death was not an abstract or esoteric exercise - but had a direct relationship to her present position. Elizabeth selected those religious authorities whose advice or writing she found most directly useful or comforting to her in coping with the loss of her husband. ${ }^{77}$ George's siblings appear to have shared in Elizabeth's search for solace through reading. 'I wonder if you are reading anything helpful now a days', Elizabeth enquired of Rachel in a 1918 letter: 'It does make one feel better. ${ }^{78}$

Elizabeth was not alone in seeking comfort in Spiritualist beliefs following a personal experience of bereavement. Many adherents of Spiritualism arrived at their faith after experiencing the death of a loved one and were motivated by a desire to reconnect with the spirits of family members. It is not surprising that Spiritualism revived during the war. As Jay Winter argues, deepening interest in Spiritualism during the war was inevitably and inextricably tied up with the need to communicate with the fallen'.79 Popular knowledge of Spiritualist beliefs was greatly advanced during the war by the publicity given it by several highly prominent advocates. One of these, the author Sir Arthur Conan Doyle, toured New Zealand and Australia in 1920 as part of a worldwide speaking tour publicising his Spiritualist beliefs. Doyle lost his son Kingsley and several other close family members during the war. After speaking to 'unusually large' audiences in Auckland and Wellington, and in front of 'crowded houses' in Christchurch, Conan Doyle arrived in Dunedin on 18 December 1920, where he delivered two public lectures on the topics of Spiritualism and Spirit Photography. ${ }^{80}$ Despite this public interest, Elizabeth does not appear to have attended any public meetings relating to Spiritualism, and made no mention of Doyle's tour in her letters. Spiritualism remained, for her, a matter of personal faith, to be shared with her

${ }^{76}$ Elizabeth to Rachel, 28 February 1918, MB-391-4/26, MBL.

77 Of Donald Hankey's, A Student in Arms (New York: E.P. Dutton \& Co, 1917) she wrote: 'I'm just beginning “A Student in Arms" \& am sure I will find it most interesting and helpful'. She referred in the same letter to having read Christ in You (London: J. M. Watkins, 1918), and wrote: 'I'm reading a little book just now called "Christ in You" - a number of 'lessons' given from the spirit world - There is no explaination [sic] of how they came - or to whom they are just real lessons \& are very comforting and helpful.' Elizabeth to Rachel, 14 August 1918, MB-391-4/26, MBL. After receiving a copy of poet John Oxenham's All's Well: Some Helpful Verse for These Dark Days of War (London: Methuen \& Co Ltd, 1915) she wrote: 'I love the following idea - from your little book - it voices what I believe to be true: 'And when He saw his work below was done. He gently called to him - My son! My son! I need thee for a greater work than this!' Elizabeth to William, 7 October 1916, MB-0985-007/004, HL. British historian Dan Todman describes Oxenham as 'by some distance the most successful British poet of the war years... his comforting vision of the war expressed within a Christian framework seems to have found a eager readership and his slim volumes had sold over seven and a half million copies by 1918'. Todman, The Great War, 155.

${ }^{78}$ Elizabeth to Rachel, 5 May 1918, MB-391-4/26, MBL.

${ }^{79}$ Winter, Sites of Memory, Sites of Mourning, 58.

80 'The Conan Doyle Lectures,' Otago Daily Times, 15 December 1920, 5; 'The Conan Doyle Lectures,' Otago Daily Times, 17 December 1920, 4; 'The Conan Doyle Lectures,' Otago Daily Times, 18 December 1920, 4. 
innermost circle of family and friends. These included Gladys Herbert, the widow of her brother Jim, with whom she held a number of seances in 1919 and 1920. Their spiritualist circle also included Mr Carr, an elderly neighbour of Mary and William Downie Stewart in Dunedin, whose wife had died in $1918 .^{81}$

While mobility of print culture allowed Elizabeth to be a party to theological discussions taking place on the other side of the world, her presence in England during the war allowed her to meet some of Spiritualism's well-known adherents in person. Elizabeth's period of residence in England during the war gave her the opportunity to discuss Spiritualism with some of the authors whose books had inspired her. Elizabeth's pragmatic approach to her religion is easily demonstrated through her contrasting opinions of two authorities on Spiritualism, both of whom she met in person. The local vicar at Brockenhurst, the Reverend Arthur Chambers (c. 1853-1918), was the author of a series of popular works on Spiritualism, the most celebrated of which, Our Life After Death; or, the Teaching of the Bible Concerning the Unseen World, published in 1894, ran to fifty editions. ${ }^{82}$ Chambers' occupation and background - as parish priest and an associate of the King's College, Cambridge, hardly paints him as a marginalised figure within English society, and supports the contention by British historians that the Church of England, while outwardly opposed to Spiritualism, in practice exercised a policy of tolerance towards clergy who publicly espoused Spiritualist beliefs. ${ }^{83}$ In April 1917, after seeing a sermon by Chambers, who she described as 'a recognised student \& a great spiritualist', Elizabeth expressed a wish to visit Chambers, 'just to have a chat' ${ }^{84}$ However, when later describing her visit to Chambers' house, she reported her disappointment at Chambers' seeming unwillingness to follow her line of questioning, and at his failure to add substantively to what she already knew on the subject: 'He wouldn't catch my point in one or two questions and insisted on answering from a different side - I felt that he didn't help me any further as I knew all he had to tell one'. ${ }^{85}$

By contrast, Elizabeth's 1918 meeting with Fanny Heslop, the author (or as Elizabeth put it 'receiver') of Speaking Across The Borderline left her deeply in awe of the

${ }^{81}$ Home circles such as these were the customary 'social vehicle' of Spiritualism. Ellwood, Islands of the Dawn, 21.

82 Georgina Byrne, Modern Spiritualism and the Church of England, 1850-1939 (Woodbridge, Boydell Press 2010), $172-173$.

83 Ibid., chapter six. For the history of Spiritualism in Britain see also Jennifer Hazelgrove, 'Spiritualism after the Great War,' Twentieth-Century British History 10, no. 4 (1999): 404-430; — , Spiritualism and British Society Between The Wars (Manchester: Manchester University Press, 2000); Janet Oppenheim, The Other World: Spiritualism and Psychical Research in England, 1850-1914 (Cambridge: Cambridge University Press, 1985); Owen, The Darkened Room.

84 Elizabeth to Rachel, 15 April 1917, MB-391-4/26, MBL.

85 Elizabeth to William, 14 October 1917, MS-0985-007/004, HL. 
woman's personal bearing and philosophy. The book, published in 1912, purported to contain messages from the spirit world from the author's deceased husband. Elizabeth sent copies to both her sisters-in-law and in sending Mary her copy in 1916 wrote 'You will probably have seen Rachel's copy... but I find this little book such a comfort to own that I am sending you one, too, so that you can pick it up \& read bits here \& there, often, as I do $-\&$ they do give strength $\&$ comfort...the ideas are so beautiful $\&$ bring ones dear ones so near'. ${ }^{86}$ After writing to Heslop in 1917, Elizabeth visited her in person at her home in Liverpool late in 1918. Describing her as 'a delicate little woman with a sweet attractive personality,' Elizabeth found her immensely comforting: 'the calm joy - confidence which radiates from her - almost more than her spoken testimony of what she has experienced convinces me of the truth behind it - I don't think I will ever be lonely in quite the same way again, tho', of course the human side of me is going to ache inexpressibly many a time before I go to rejoin my mate. ${ }^{87}$

Homecoming was not an eagerly anticipated event for Elizabeth. A series of letters narrating her return to New Zealand, in 1919, powerfully convey her mounting sense of apprehension as she drew nearer to the familiar surroundings of her home district. Her ship docked at Port Lyttelton in June 1919. Travelling southwards by night train through South Canterbury and North Otago, she was thankful for the dark that prevented her from recognising the familiar outlines of the landscape outside her carriage window. 'I had quite a pleasant journey down \& when I finished my book pulled my rug well round my shoulders $-\&$ thought. I was glad of the dark for then I was not forced to recognise the increasingly familiar surroundings - \& I just thought of all the wonderful things that I know of that brought strength \& comfort'. ${ }^{88}$ On her arrival in Dunedin, visiting the Stewart family home of Ashentree, a place intimately associated with George's childhood, presented a further challenge to Elizabeth. She confessed to Rachel 'I am thankful I am not staying there for the familiar surroundings made me very heart hungry - tho' I think I hid the fact successfully enough ... The nearer I get to "Westwood" the more I miss the dear human presence which made home home.... ${ }^{89}$

\footnotetext{
${ }^{86}$ Elizabeth to Mary and Rachel, 20 October 1916, MS-0985-041/002, HL.

${ }^{87}$ Elizabeth to Rachel, 5 December 1918, MB-391-4/26, MBL.

${ }^{88}$ Elizabeth to Rachel, 4 June 1919, MS-0985-041/003, HL.

${ }^{89}$ Elizabeth to Rachel, 4 June 1919, MS-0985-041/003, HL.
} 


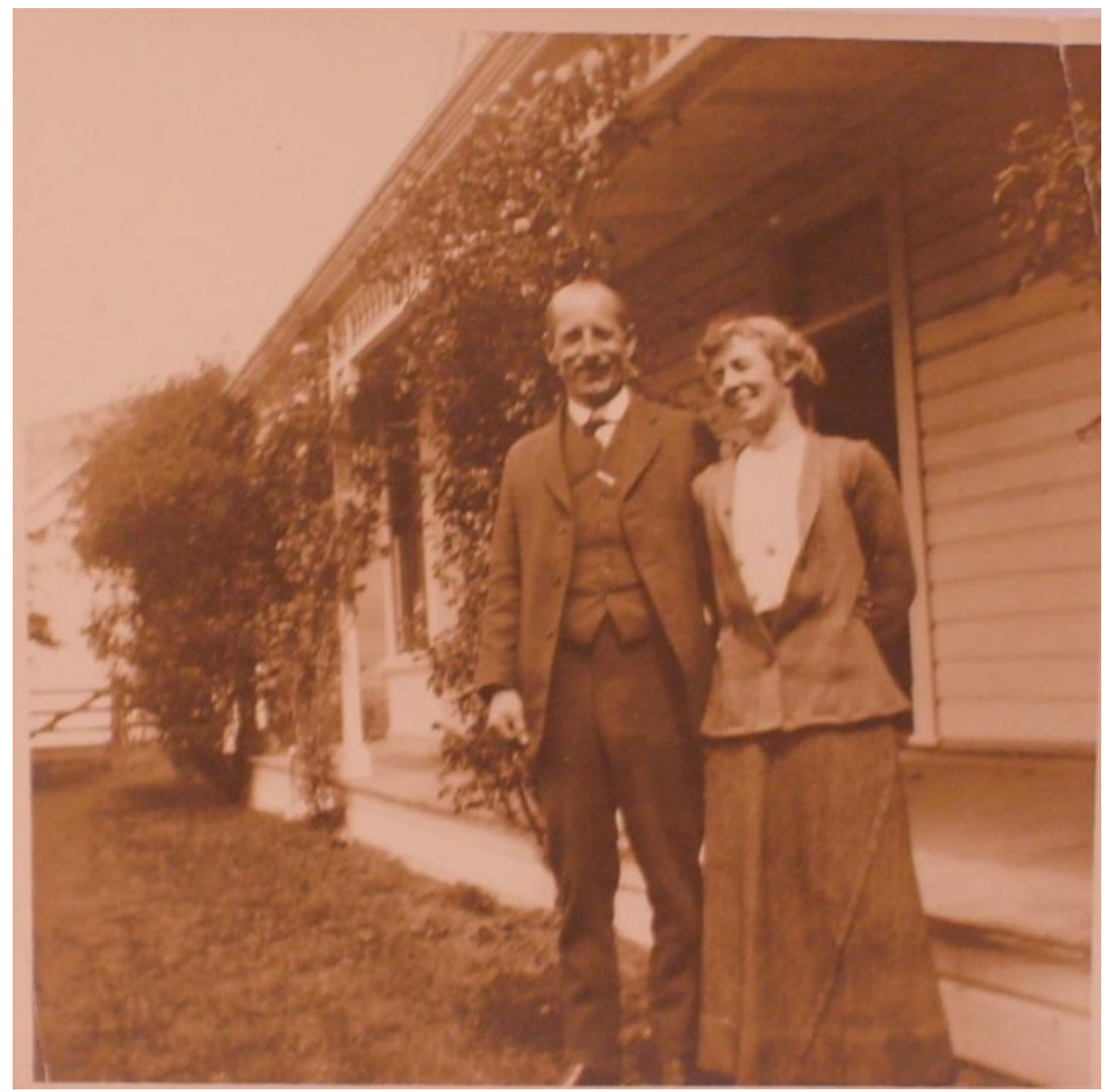

George and Elizabeth Stewart at Westwood, c. 1912

Source: MS-0985-057/007, HL.

The precise moment of Elizabeth's return to Westwood is not documented in her letters. However, writing six months later, she credited coming home with the return of the sense of peace she had been lacking since George's death. She wrote to Rachel in November 1919, six months after her return to the property: 'It is such a lovely evening \& I am all alone - but not a bit lonely! Georgie is very near \& with this knowledge comes a great peace'. ${ }^{90}$ It is no coincidence that Elizabeth's bridging of geographical distance, represented by her return to Westwood, also marked the beginning of her most sustained efforts to connect to George through spiritual channels. It was at Westwood - the place that above all others signified George's love and memory - that Elizabeth adopted the practice of automatic writing. That Westwood, for Elizabeth, formed the perfect environs to connect with the spirit world is clear in a letter she wrote to William on the topic of her 'communications' with his mother, Rachel Hepburn

${ }^{90}$ Elizabeth to Mary, 13 November 1919, MS-0985-050/002, HL. 
Stewart. Nowhere else could offer more perfect conditions than does this dear little home of mine \& your Mother's closing sentence was most comforting \& encouraging "Go on trying to write automatically \& good will come to many others through our advice". ${ }^{91}$

In a November 1919 letter, Elizabeth described to William (Downie) the method she adopted for communicating with the spirit world:

This morning your mother came to me (thro' automatic writing). I had sat in the usual way asking for nothing in particular but trying to leave my mind open to any message of help \& encouragement that might be granted, \& almost at once after a little bungling I got the message "Go on giving good thoughts of health for Downie - in spite of doctors [sic] verdict Downie will meet a doctor gone off on other lines of mending \& later in answer to my question "do you want me to help Downie" "Get him to stand for Parliament \& he will win" - Go on giving good thoughts of other healing \& the way will be shown when the time is come for healing!" So there you are, my dear - \& you know that I have perfect faith in the truth of these messages or I could not pass them on... ${ }^{92}$

On some occasions, Elizabeth's Spiritualist faith brought her true solace. She wrote in 1918 'repeatedly I hear of sad cases all round - cases far worse than mine, for I have the wonderful treasure of our love bright \& undimmed - indeed growing always more radiant... ${ }^{93}$ While by her own account, Elizabeth succeeded in making 'contact' with the spirit world, her descriptions of her experiences of automatic writing also point to the religion's limitations as a source of comfort for the bereaved. In her pursuit of Spiritualism, described by David Cannadine as the 'private denial of death', Elizabeth was confronted, again and again, by the simple fact of George's absence. ${ }^{94}$ While a desire to communicate with George lay at the heart of Elizabeth's efforts to commune with the spirit world, she only managed, by her account, to establish 'contact' with his mother, whose chief object appeared to be to proffer advice to her surviving children. The spirits, it seems, also suffered the same barriers to effective communication as did the inhabitants of the human world. As Elizabeth reported in a 1920 letter: 'Our spirit friends have difficulty in expressing themselves ...often their phrases are awkward \&

\footnotetext{
91 Elizabeth to William, 9 November 1919, MS-0985-007/004, HL.

92 Ibid.

93 Elizabeth to Rachel, 11 October 1918, MB-391-4/26, MBL.

94 Cannadine, 'War and Death,' 227.
} 
stunted' and 'sometimes abrupt'. ${ }^{95}$ Like humans, they also risked causing friction and offence through their utterances, as occurred when Elizabeth relayed the results of her latest communications with the spirit world to Mary in January 1920. Upon asking Rachel Stewart if she had any messages to pass on to her children, she was said to have responded: "Yes - more love to all \& to George Armitage \& to one another. May is always too angry - good thoughts will work more \& help Rachel \& all more, \& make George Armitage \& Rachel happier”. Then came a message for me \& the farewell "Goodbye Elizabeth George loves you more all the time" - I asked 'You want me to deliver this message \& got the reply "yes, to May". So I give it to you as I got it thro', for I consider it a very sacred trust \& am only sorry that I am not able to give better conditions \& get fuller results'. ${ }^{96}$ Unsurprisingly, Mary took offence at this message, prompting several conciliatory letters from Elizabeth in early 1920.

Aside from the occasional letters dating from 1920s and 1930s, the once regular flow of correspondence between Elizabeth and George's siblings had ceased to a trickle by the early 1920s. With Elizabeth living nearby, there was less of a need to write, although it is also possible that the participants in this exchange found an epistolary relationship easier to sustain than one conducted face to face. Elizabeth continued to live at Westwood until around 1921. She adopted a daughter, Virginia, as an infant in the early 1920s and by 1922 the pair had moved to live at 'Khutzu', a house she had built in the Dunedin suburb of Roslyn. In 1926 she remarried, to Frank Cecil Taylor, a man eighteen years her junior, a returned soldier, accountant, and, allegedly, her medium. ${ }^{97}$ By the act of her remarriage, Elizabeth formally and effectively severed her relationship with the Stewart family. While Mary wrote to Elizabeth wishing her well, her true feelings about her sister-in-law's remarriage were betrayed in an earlier letter to Rachel. Recounting an exchange with her housekeeper, Mary told Rachel that Miss Bagshaw had informed her of rumours that Elizabeth was to be married, to which Mary replied testily: 'I told her Mrs Stewart would never marry \& that I thought it a great pity for such wicked rumours to get about! ${ }^{98}$ A family rift arising from this period may explain why Elizabeth left George's nephew George Armitage out of her will, while

\footnotetext{
${ }^{95}$ Elizabeth to Mary, 16 January 1920, MS-0985-050/002, HL.

${ }^{96}$ Elizabeth to Mary, 2 January 1920, MS-0985-050/002, HL.

${ }^{97}$ The suggestion that Frank Taylor was Elizabeth's medium was made in two letters in the family papers. Mary commented to Rachel upon learning the news of Elizabeth's impending marriage 'I think the bond between them is Spiritualism’. Mary to Rachel, 23 May 1926, MS-0985-040/011, HL. A letter by their distant cousin Mary Stewart Bartleman asked whether Frank Taylor was 'the young man who lived with her who was her medium people said'. Stewart Bartleman to Rachel, c. 1926, MB-391-15/114, MBL.

${ }_{98}$ Mary to Rachel, 23 May 1926, MS-0985-040/011, HL.
} 
providing generously for his brother William Stewart Armitage. ${ }^{99}$ Elizabeth, now Elizabeth Woodhead Taylor, retained the Westwood property under management until 1953, when it was sold to members of the Stewart family. While only a few of her letters beyond the 1920s survive, those that do exist affirm the continuing power of Westwood to evoke powerful memories of George for Elizabeth. In the summer of 1933, she and her family spent their holidays at Westwood '\& spent hours on the lawn saturating ourselves with sunshine \& peace': 'I read over again George's letters \& brought back the essence of those days'. ${ }^{100}$

In the title of Fanny Heslop's book to 'speak across the borderline' was to connect across borders that seemed insurmountable. While the book and its author inspired Elizabeth, it is also a useful descriptor of this chapter's central themes. Elizabeth attempted to speak across the borderline in two senses. The first is that intended by the title of F. Heslop's book: a place where the dead were always present and the living might learn to communicate with them. But 'speaking across the borderline' also points to some of the limitations of that faith. For, in spite of her intense efforts to connect with her husband's spirit, Elizabeth's relationship with George remained a broken connection, unable to bridge the final borderline of life and death.

The second form of borderline was geographical separation. As Elizabeth's exchanges with the siblings of her husband suggests, shared grief could form a common bond that transcended geographical space, and the boundaries of home and front. The epistolary exchange which lies at the heart of this chapter provided the means by which Elizabeth was able to keep George 'near' through cultivating her relationship with his close family members, as well as a means to share her experience of grief with others who felt the same deep sense of loss at George's death. While grieving spouses or other relatives came under pressure to conform to societal expectations that they would maintain their composure and remain 'brave' in the face of their loss, Elizabeth's letters to George's siblings provided a space in which she could voice her true state of mind and feelings. However, as Elizabeth's case also suggests, grief could pull individuals in the opposing direction, towards maintaining distance from home as a way of delaying

\footnotetext{
${ }_{99}$ William Armitage inherited $f_{1000}$ in Elizabeth's 1961 will 'in appreciation of his unfailing courtesy and loyalty to me'. This comment seems rather pointed in light of the fact that his brother George Armitage is not mentioned at all. 'Elizabeth Taylor - probate file,' DAAC/9076/728/602/67, ANZ.

${ }^{100}$ Elizabeth to Mary, 7 February 1933, MS-0985-050/002, HL.
} 
the full force of her grief. While a valuable form of support during her absence from New Zealand, this relationship weakened after her return, and was virtually severed by her remarriage. Borderlines also evoked the separation of loved ones from the war dead and their sites of burial that constituted the common experience for the bereaved families of New Zealand soldiers. Elizabeth's mobility allowed her to be at her husband's deathbed, and to participate in his burial. Her experience of wartime bereavement represented a reversal of the usual experience of most New Zealand families. A more typical experience of wartime bereavement was that of George's siblings back in New Zealand, to which the next chapter now turns. 



\section{CHAPTER FOUR:}

\section{WORDS OF COMFORT AND SORROW: GRIEF AND REMEMBRANCE IN THE DEATH OF GEORGE STEWART.}

Ten days after George Stewart's death in an Australian military hospital on the Greek Island of Lemnos, the first notices of his death appeared in a New Zealand newspaper. ${ }^{1}$ Over the days and weeks that followed, the news reached friends, family and colleagues in New Zealand and around the world. Some recorded their reactions. Rose Sweet, a friend of George's sister Mary, living in Japan, saw George's portrait in a newspaper Roll of Honour and wrote to Mary 'I recognised his face from the picture, and in a moment I realized that you had lost him'. ${ }^{2}$ Reading George's name in the casualty list caused his half-sister Ethel Nisbet to reflect upon the imbalance between a single line printed in a newspaper and the weight of loss a soldier's death represented for his relatives: 'You have been constantly in my thoughts ever since I saw the brief line (that meant so much to you) in the Casualty list'. ${ }^{3}$ As the news travelled, members of the Stewart family's extensive kin and friendship networks responded according to pre-war custom: sending telegrams, cards, and letters of condolence to the immediate family. Three hundred and twenty three items of this correspondence, including 235 letters, 44 telegrams and 44 sympathy cards, survive in the collections of the Hocken and Macmillan Brown libraries, providing rich documentation of the outpouring of grief in relation to a single war death. ${ }^{4}$

Scholars of wartime bereavement emphasise the new bonds that were forged out of the shared experience of grief, as those mourning wartime losses sought mutual consolation and then to commemorate the dead. ${ }^{5}$ This chapter aims to reconstruct two

\footnotetext{
1 The first notice of George's death appeared in Dunedin's Evening Star on 30 November 1915.

2 Rosie Sweet to Mary, 30 January 1916, MS-0985-033/006, HL.

${ }^{3}$ Ethel Nisbet to Elizabeth, 28 December 1915, MS-0985-033/002, HL.

4 These letters represented a total of 265 correspondents, as some wrote to more than one family member, or sent two different items of condolence to the same individual, such as a telegram and a condolence letter.

5 Audoin-Rouzeau and Becker, 14-18, 204-207; Winter, Sites of Memory, Sites of Mourning, 29.
} 
such 'communities of mourning'. ${ }^{6}$ The first is the epistolary community made up of the individuals or families who sent letters, cards, or telegrams of sympathy to the Stewart family following George Stewart's death. Second is the geographical community of mourning centred on George Stewart's home district of Crookston. The chapter's point of entry into Crookston life is through a family memorial album dedicated to George Stewart's life and memory. This album provides a rich record of community life in Crookston, and places George Stewart at the centre of it as a prominent local figure, heavily invested in the life of his district. It also documents a series of memorial events dedicated to George Stewart that took place in the district following his death, using these to reflect more widely upon the nature of wartime commemoration in homefront communities.

Both condolence letters and wartime remembrance provide a source of insight into the masculine attributes most prized among the Stewart family's circles. In its use of condolence letters to explore masculinity, this chapter follows the lead of Jessica Meyer. In letters of condolence, Meyer writes, 'the masculinity of the dead man is constructed by others seeking to define him in terms of their recollection of him, be that as a civilian or a soldier'. ${ }^{7}$ However, this chapter's analysis will suggest that men's civilian and domestic identities were less thoroughly supplanted by heroic tropes of masculinity than Meyer's study of British condolence letters found. Those who wrote to express sympathy to George's family were more likely to call attention to his attributes as a neighbour, colleague, or family man than they were to his qualities as a soldier or officer. ${ }^{8}$ In the various memorial services held to commemorate George's life, the devotion to duty he exhibited as a soldier was seen by his contemporaries as consistent with the qualities of service he displayed as a citizen of his local community. Drawing upon the condolence letters and the G. H. Stewart album, the chapter also explores the nature of homefront communities of mourning. Here, the chapter points to the importance of shared values of duty and service, and of existing networks of Christian faith, in shaping the forms that condolence and later commemoration, took.

\footnotetext{
${ }^{6}$ Audoin-Rouzeau and Becker use the term 'communities of mourning' to describe the emergence during the war of new collectivities bound by their experiences of bereavement. See Audoin-Rouzeau and Becker, 14-18, 204-207. ${ }^{7}$ Meyer, Men of War, 12.

8 Ibid.
} 


\section{Condolence letters}

Like all forms of letter-writing, specific conventions guided the content and style of condolence letters, and directed to whom and by whom they could be sent. In terms of form, condolence letters were usually relatively short - typically one or two pages in length - and contained little beyond observations relating to the death. Mabel Orbell, a friend of Mary's, referred to this convention in her condolence letter when she wrote in reference to Mary's patriotic work: 'This is not the time to thank you for all you did last week - but I do not want you to think I had forgotten it." Writers of condolence letters, aware that their letter's recipient would be burdened by a heavy load of correspondence, frequently stated that their letter required no response. Such an instruction would have been unusual in most other forms of letter, which generally relied upon a pact of reciprocity. ${ }^{10}$ Eric Alcott, an army comrade of George's, wrote to Elizabeth: 'I know you will have a great number of notes to write in answer to messages of sympathy so please do not trouble to answer this. I wish I could do something more to help you. ${ }^{, 11}$ The Stewart siblings' cousin Jessie Guthrie wrote: 'Please don't trouble to answer this for I know how hard it is to write when one is heart broken'. ${ }^{12}$ Although such appeals were common, their letters' recipients probably replied regardless. ${ }^{13}$

Those who sent expressions of sympathy to members of the Stewart family readily appreciated both the comforts and limitations of such gestures. In doing so, many were able to draw upon their own personal experiences of bereavement. Paton Dunlop, a Crookston farmer, wrote: 'From my own experience, I know that in the dark, blank, lonely days that follow a great sorrow, the smallest word or look of sympathy is appreciated. ${ }^{14}$ Family friend George Lyon Denniston, whose son Thomas had died of enteric fever while on active service earlier that year, wrote: 'I know from experience just what the expressed sympathy of your friends can \& cannot do. It comforts in a sense \& one likes to know that those who have been taken from us were liked \& appreciated. But nothing can remove the sharp sting of a personal loss that makes the

\footnotetext{
9 Mabel Orbell to Mary, 2 December 1915, MS-0985-033/007, HL.

${ }^{10}$ Liz Stanley, 'The Epistolary Gift, the Editorial Third-Party, Counter-Epistolaria: Rethinking the Epistolarium,' Life Writing 8, no. 2 (2011): 140.

11 Eric Alcott to Elizabeth, n.d., MS-0985-051/014, HL.

12 Jessie Guthrie to Rachel, 7 December 1915, MS-0985-033/003, HL.

13 William wrote on 12 December 1915, 'I have about finished writing to all the people who wrote to me \& I will post all their letters to you or give them to you at Trentham.' William to Rachel, 12 December 1915, MS-0985-039/002, HL.

14 Paton Dunlop to Mary, 16 January 1916, MS-0985-033/001, HL.
} 
world feel so empty \& life for the time being so savour-less. ${ }^{, 15}$ Other correspondents expressed frustration at their inability to translate their true feelings into words, or attributed their letter's shortcomings to a failure of language to express emotion. Frances Sim, a family friend wrote: 'It is useless to attempt to convey our feelings in words there are some sympathies too deep for cold expression, and this one for you and your brother...must lie as an emotion too deep for utterance. ${ }^{16}$ But despite such misgivings, the outpouring of letters of sympathy in response to George's death was both immediate and numerically significant.

The recipients of condolence letters could gain comfort from the knowledge that their wider circles of friends and family sympathised with them in their loss. Pat Jalland has argued of nineteenth-century condolence letters that their primary function lay in 'expressing and activating the sympathy and affection of support networks'. ${ }^{17}$ However, the outpouring of condolence that followed George's death does not support Jalland's claim that, during the war, condolence letters lost their power to comfort the bereaved. Instead, Jalland argues, they seemed to 'underline the hopelessness of the bereaved and the declining stocks of sympathy and energy among underworked family and community. ${ }^{18}$ George's wife Elizabeth, referring to her receipt of condolence letters, clearly appreciated the sentiment in which they were sent. She wrote in January 1916: 'The incoming mail this week brought me my first letters referring to our dear one's passing on - such beautiful expressions of admiration \& regret for George \& of love \& sympathy for me! They helped wonderfully but of course they made me very sad \& I have had hard work to keep myself in hand. ${ }^{19}$

Most of this chapter's analysis is based on condolence letters, rather than the shorter forms of the sympathy card or telegram. Condolence letters reflected the Stewart family's wider social and professional networks as much as the specific contacts of George Stewart. Some correspondents who wrote condolence letters barely knew or had never met George, and were activated to write solely through their relationship with his family members. Over half of the correspondence preserved in this collection of

15 G. Denniston to Mary, 30 November 1915, MS-0985-033/003, HL. The writer, G. L. Denniston was the brother of Sir John Denniston, a Supreme Court Judge who had trained in the legal practice of William Downie Stewart (snr). Another son, George Gordon Denniston, survived the war, but one of G. L. Denniston's nephews, Douglas F. Cuthbertson, also died.

${ }^{16}$ Frances Sim to Mary, 1 December 1915, MS-0985-033/005, HL. Frances Sim was the wife of Justice William Sim.

17 Jalland, Death in the Victorian Family, 372.

18 Ibid.

${ }^{19}$ Elizabeth to Mary and Rachel, 17 January 1916, MS-0985-041/002, HL. 
condolence letters was addressed to Mary. Mary's correspondents reflected her wide circles of personal and family friends, mostly Dunedin-based, many of them belonging to the upper echelons of Dunedin 'Society'. Mary, because of her long-term residence at Crookston, also formed the link between the distinct social worlds of rural West Otago and the urban circles of the Dunedin elite. William's condolence letters reflected his wide circle of professional contacts in the legal profession and politics in Dunedin and Wellington. Rachel's Temuka friends and neighbours dominated her correspondence, as well as relatives and Dunedin-based friends. Elizabeth's correspondence was made up of friends, Crookston residents and relatives, George's professional colleagues and fellow soldiers and officers. ${ }^{20}$ Although letters from members of the military form a part of Elizabeth's correspondence, the Stewart family collection is primarily a record of civilian and homefront bereavement and differs in this respect from other large collections of war-time condolence letters. ${ }^{21}$

Gender formed one of the most important determinants of the form that condolence took. As seen in Figure 4.1 below, female correspondents outnumber men significantly as authors of letters and sympathy cards, although men were more likely to send condolence telegrams. Overall, as shown in Figure 4.2, female correspondents dominate as senders of messages of condolence, with 58 per cent of the items of condolence sent by women, where the item was sent by a single individual of known sex, compared with 42 per cent by men. Further separating out the sex of senders and recipients, as in Figure 4.3, reveals that correspondents were most likely to write to an individual of the same sex. A condolence letter Mary received from family friend G. Turton appears to acknowledge the existence of such a convention: 'I did not write to Willy, as I thought he would be overwhelmed with letters from his men friends but I know well how much George was to him \& how he will feel his loss'. ${ }^{22}$ This difference is marked in the case of Mary, Rachel and William's letters, but less notable in Elizabeth's. This was probably a consequence of the higher representation of former military and professional colleagues of George's in letters to his wife.

20 The letters to Elizabeth preserved in the Stewart family papers are those she sent back to George's family members for safe-keeping, and it is highly likely that she received other letters that were not preserved.

21 ATL holds 29 First World War condolence letters received by the Knight family of Dannevirke after the death in the war of their three sons. See Knight Family Papers, MS-Papers-5548-11, ATL. Only military correspondents are represented, suggesting that letters from other correspondents had been culled from the collection, probably before it reached the archive.

22 G. Turton to Mary, 15 December 1915, MS-0985-051/014, HL. 


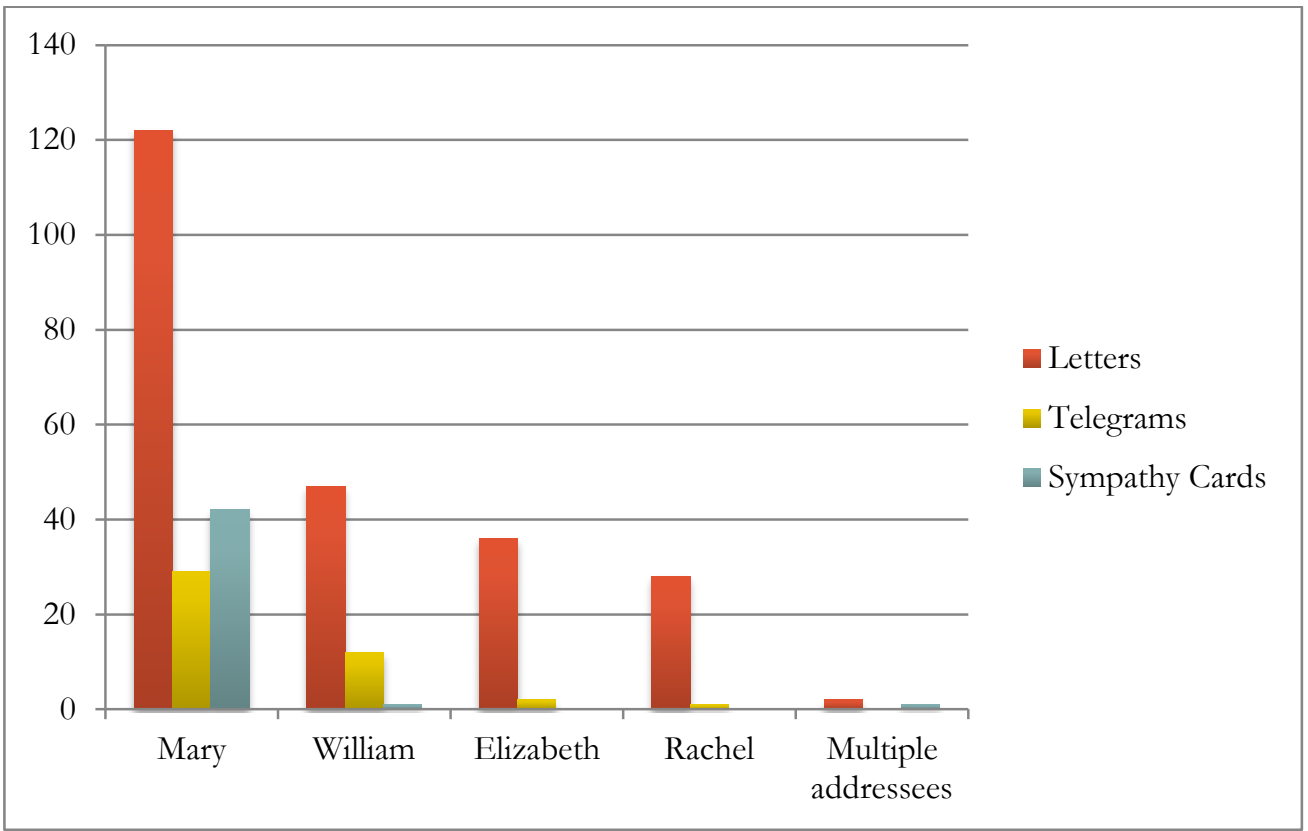

Figure 4.1: Total items of condolence by recipient.

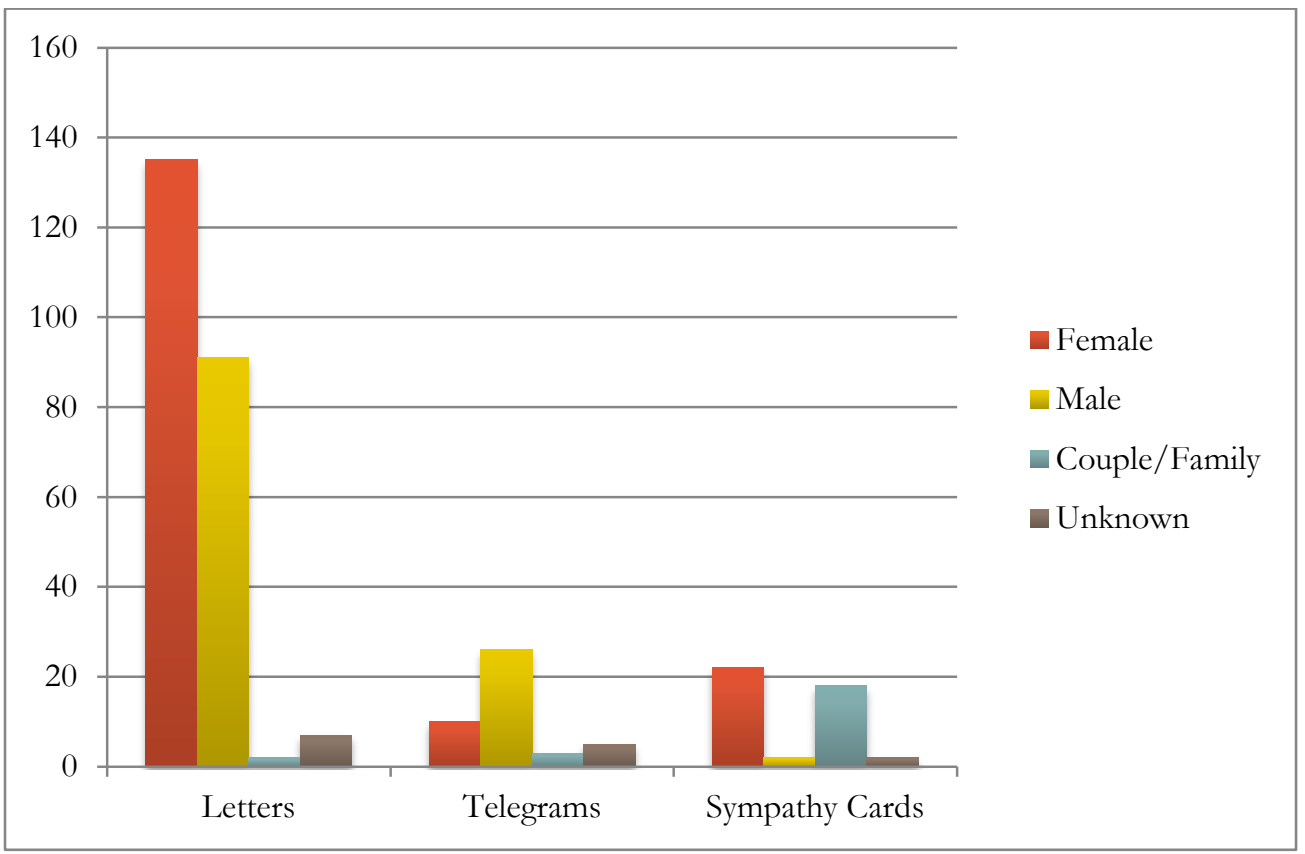

Figure 4.2: Items of condolence by sex of correspondent. 


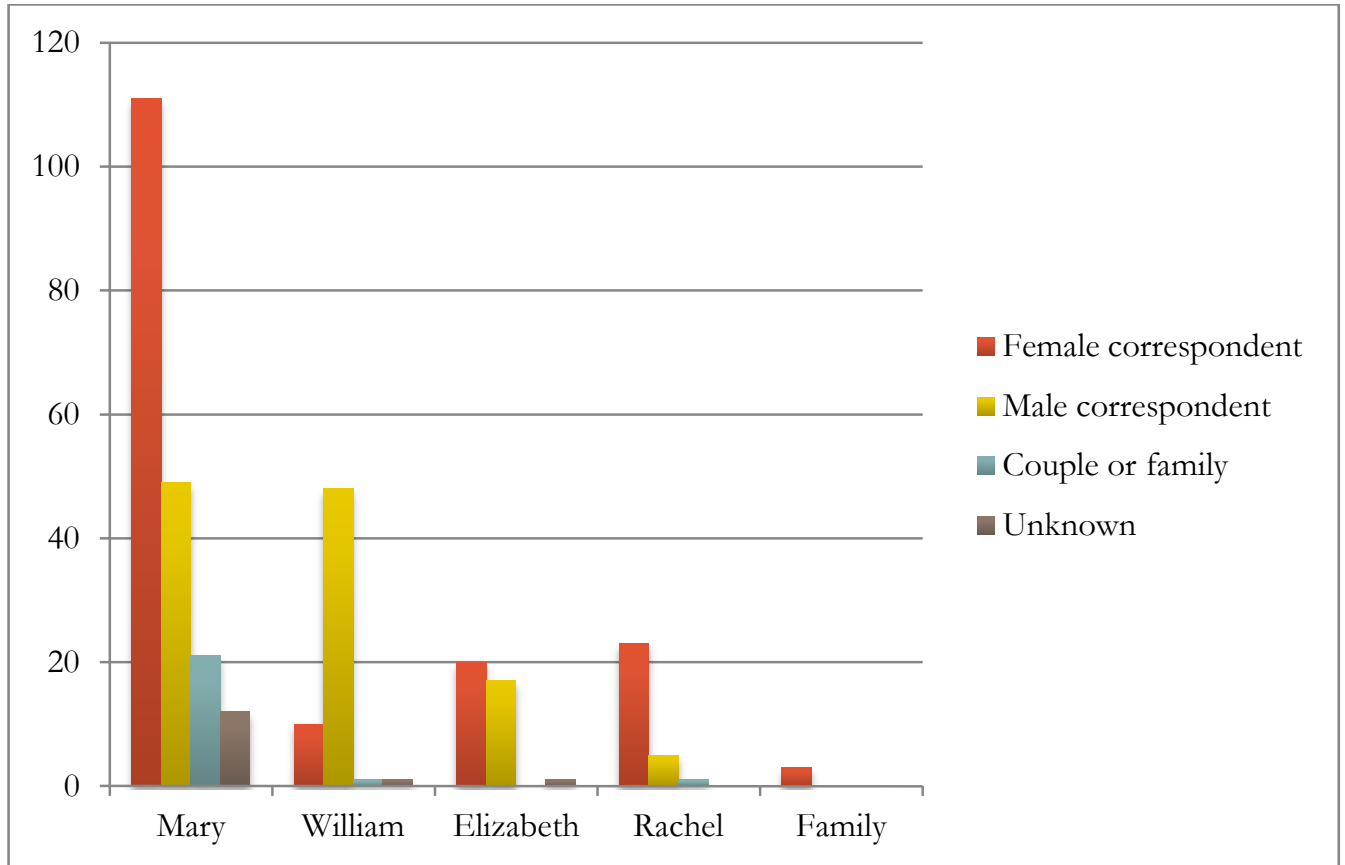

Figure 4.3: Authors of telegrams, sympathy cards and letters by sex of correspondent.

\section{G. H. Stewart Memorial Album}

Decades after George Stewart's death, probably as late as the 1950s, a member of the Stewart family compiled an album dedicated to his memory. Bound in brown leather and embossed in gold lettering with the title 'G. H. Stewart 1875 - 1915', the album contains close to 80 pages of newspaper cuttings, photographs and ephemera relating to George Stewart's life in Crookston, military service, and death. The album's creator was almost certainly his sister Mary. The G. H. Stewart memorial album is comparable to similar albums created by grieving families elsewhere. The extensive 'record books' compiled by grieving Melbourne father Garry Roberts in response to his son's Frank's death form a significant body of evidence for several Australian studies of wartime grief. ${ }^{23}$ While Roberts began to amass materials for his scrapbooks shortly after his son's death, the G. H. Stewart memorial album is the product of an even more protracted grieving process. The album's last entries date from the 1950s: a 1950 newspaper clipping on a sermon delivered at St Andrews Presbyterian Church by the Reverend Robert Menzies, on 'the problem of lives cut short', and an article dated 12 March 1957, on the death of General Alexander Godley. Several clues suggest that the entire album

${ }^{23}$ See Damousi, Labour of Loss, 58-64; Luckins, The Gates of Memory; Stanley, The Men of Mont St Quentin. For a discussion of family memorial albums in the British context see Roper, The Secret Battle, 223-227. 
was compiled by Mary in the 1950s. The handwriting of the album's annotations is recognisably Mary's and shows the signs of deterioration seen in other letters written in her old age. The non-sequential ordering of the material in the album also points to the conclusion that the entire album was compiled at one time, rather than created earlier and added to. The 1957 article on Godley's death mentioned above, for instance, appears on the same page as a 1916 article on Godley. Mary, the last surviving member of the four siblings, died just over two weeks after the last clipping was pasted in the album. The G. H. Stewart album documents George's life from his early childhood and schooling right through to his death. For this chapter's purposes, the album's main significance is in its thorough documentation of George Stewart's contributions to Crookston life and of the ways he was remembered by his local community after his death. In recording his life and death, the album paints a picture of George Stewart as a man with a life-long commitment to serving his community.

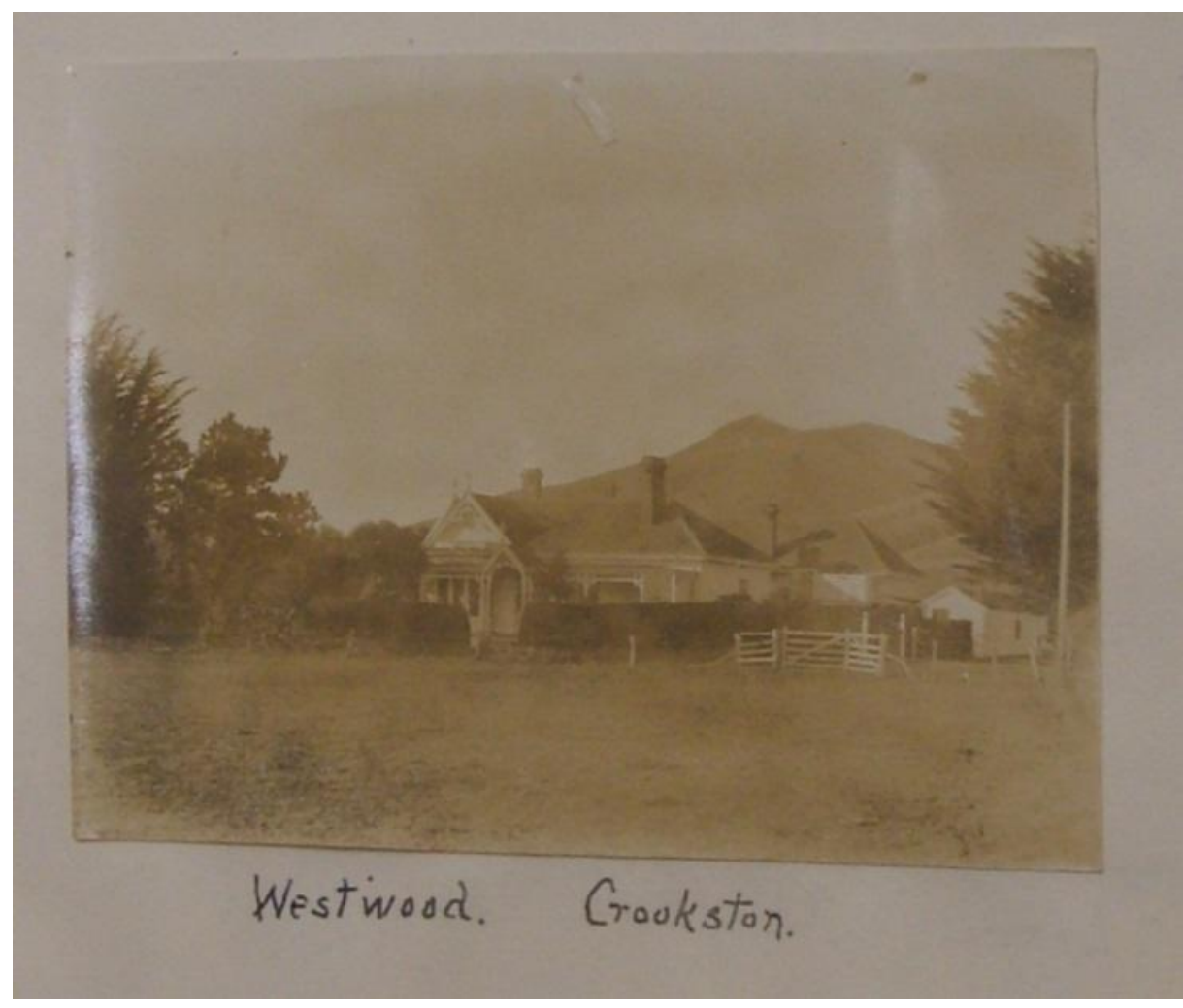

Figure 4.4: 'Westwood', Crookston

Source: G. H. Stewart Memorial Album, MS-0985-033/008, HL. 


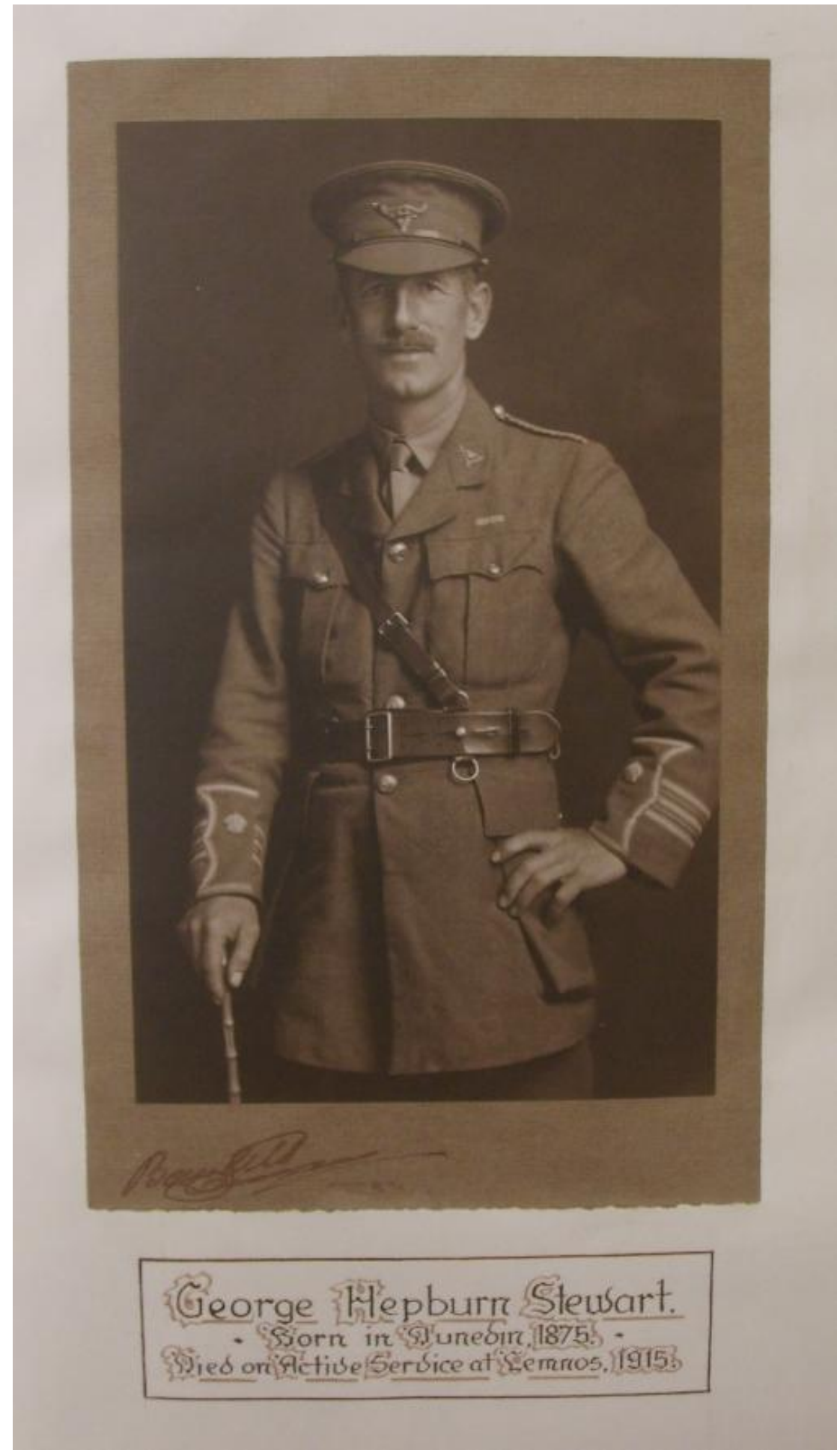

Figure 4.5: Title page, G. H. Stewart memorial album

Source: MS-0985-033/008, HL. 


\section{Crookston, West Otago}

George Stewart purchased the 400 acre freehold farm he named 'Westwood' in the small rural community of Crookston, West Otago, in 1898. Like many of his neighbours, he adopted mixed farming, 'the Scotch method of modern farming': rotating root crops such as turnips with grains such as oats, wheat and barley, and the grazing of sheep. ${ }^{24}$ He joined the district's 107 permanent inhabitants, the majority of whom were farmers or engaged in rural support industries, including two blacksmiths, a sawmiller, a storekeeper and a combined teacher and postmaster. ${ }^{25}$ The surviving historical records of the district's population favour permanency and property. They excluded the itinerant male labour force who undertook seasonal work such as shearing and harvesting, or culled rabbits in the off-season. ${ }^{26}$ A small number of Chinese miners left over from the region's mining boom were still resident in the district in the $1890 \mathrm{~s}^{27}$ There was no permanent Ngai Tahu community in the district, the area having been used by local Māori for seasonal hunting and fishing trips. ${ }^{28}$ The first European settlers who began to arrive in the area from across the Taieri plains in the 1860s considered themselves the legitimate inheritors of the land.

Community institutions such as a hall and Church arrived late to Crookston relative to neighbouring settlements. While a school had been established in 1878, the district's first Presbyterian church was not built until 1899, the year of George's arrival to the district. ${ }^{29}$ In small rural communities such as Crookston, dual-purpose buildings were a necessity. Thus, the Crookston public hall, opened in 1907, housed the district's Athenaeum, while the Crookston school doubled as the post-office; the teacher as postmaster. Crookston also had a blacksmith's shop, established in the late 1880s at the junction of the roads between Tapanui, Rae's Junction, and Heriot. ${ }^{30}$ Crookston locals travelled to neighbouring townships such as Tapanui and Kelso for goods and services

\footnotetext{
24 'Tapanui Station: Brooksdale Estate,' Tapanui Courier, c. 1910, in MS-0985-033/008, HL.

${ }^{25}$ Crookston's population of 107 remained unchanged in the Wise's Directories over the period 1905-1915. Wises New Zealand Post Office Directory, 1905 (Auckland: BAB Microfilming, 1992); Wises New Zealand Post Office Directory, 1910 (Auckland: BAB Microfilming, 1992); Wises New Zealand Post Office Directory, 1915 (Auckland: BAB Microfilming, 1995). Crookston fitted into the category of small nineteenth-century town David Hamer describes as existing solely to service its surrounding farming district. D. A. Hamer, 'Towns in Nineteenth-Century New Zealand,' NZJH 13, no. 1 (1979): 7-8.

26 A rabbit factory in nearby Kelso employed over 40 men. Miller, Beyond the Blue Mountains, 49.

${ }^{27}$ In 1888, Tapanui had a Chinese population of 30. Malcolm McKinnon, ed., New Zealand Historical Atlas: Ko Papatuanuku e Takoto Nei (Auckland: David Bateman; Department of Internal Affairs, 1997), plate 45.

28 Atholl Anderson, The Welcome of Strangers: An Ethnobistory of Southern Maori A.D. 1650-1850 (Dunedin: Otago University Press, 1993), 183.

${ }^{29}$ Miller, Beyond the Blue Mountains, 144. The first religious services in Crookston were held on W. H. Lusk's farm around 1878. 'Tapanui Station: Brooksdale Estate,' Tapanui Courier, c. 1910, in MS-0985-033/008. Later, they were held in the school.

${ }^{30}$ Miller, Beyond the Blue Mountains, 51.
} 
not offered in their immediate settlement. They had to travel even further afield to visit their nearest seats of government. Crookston fell within the Clutha electorate, with its Member of Parliament based in Balclutha, and under the jurisdiction of the Tuapeka County Council, with its headquarters in Lawrence, separated from Crookston by the Blue Mountains. ${ }^{31}$ From 1903 to 1915, George Stewart served as Crookston's elected representative on the Tuapeka Council, making the journey to Lawrence monthly. ${ }^{32}$

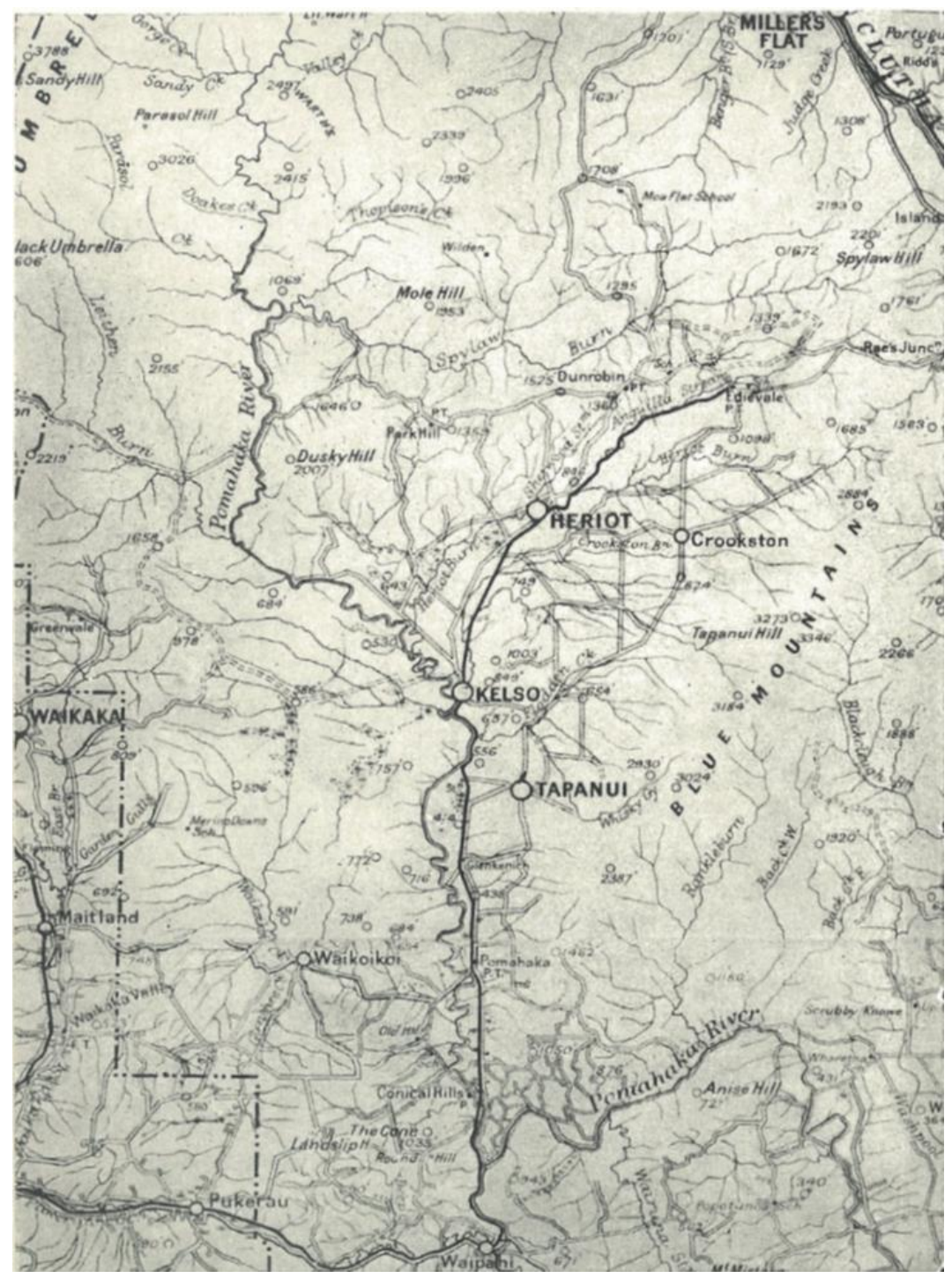

Figure 4.6: Map of West Otago District

Source: Miller, Beyond the Blue Mountains, frontispiece.

\footnotetext{
${ }^{31}$ Little exists of Crookston today, it having succumbed to a fate Hamer describes as common among small nineteenth-century settlements: near extinction in the face of improved transport and communication technologies. Hamer, 'Towns in Nineteenth-Century New Zealand', 6-7.

${ }^{32}$ Serving on local councils and committees was a popular pastime among the Otago and Canterbury rich in this period. See McAloon, No Idle Rich, 147-149.
} 
George Stewart was engaged in community and public life to an unusual degree for a man of his occupation. Few other Crookston farmers could boast the same extensive circles and influence. This point was highlighted by his obituarist in the Presbyterian national paper The Outlook who pointed out that George Stewart's wealth and 'social position' had 'enabled him to take a larger part in public affairs than is possible for an average farmer'. ${ }^{33}$ The same obituarist went on to highlight the acquired rather than inherited nature of 'manliness' in describing how George Stewart, an outsider, came to be accepted by Crookston farmers. ${ }^{34}$ In Dunedin, the Stewarts enjoyed the social status of being among the city's leading families. The same background proved less advantageous in rural Crookston. There, his training as 'a Lincoln College student' and family background 'as the son of a leading barrister' predisposed local farmers to adopt 'an attitude of guarded observation as to his methods of work and his bearing generally'. It testified to George Stewart's manly attributes of 'sound sense and perfect frankness of manner', his Outlook obituarist held, that he 'eventually won the favour of all,.$^{35}$ The same quote also pointed to another key aspect of masculine status: its validation through peer recognition and public acclaim. ${ }^{36}$ It was George Stewart's 'character and capacity', not the advantages of his background, that finally 'won him public confidence in so full a measure' ${ }^{37}$ Finally, following nineteenth-century ideals of manliness, George Stewart's outward conduct was underpinned by strong inner qualities: 'His was essentially a nature of finer mould, a life of genial humour, with its undertone of dutifulness and sincere faith... We loved his genial humour more because we knew how sensitive and how true to the highest was the life beneath it. ${ }^{38}$

The timing of George Stewart's arrival to the Crookston district in the late 1890s allowed him to play a part in the establishment of many of its public institutions. His obituarist in the local newspaper the Tapanui Courier only mildly exaggerated when he wrote that 'Mr Stewart from the time he came into the district identified himself with all its public institutions. In the immediate settlement of Crookston he occupied a place on every public body, and it was not long before he was enrolled by almost every institution in the district. Many of them he was not greatly interested in, but he withheld his

\footnotetext{
33 'Roll of Honour,' The Outlook, 21 December 1915, in MS-0985-033/008, HL.

34 Tosh describes nineteenth-century manhood as 'essentially an achieved status. It was not a birthright, but lay within the power of one's peers to confirm or deny'. John Tosh, Manliness and Masculinities in Nineteenth-Century Britain (Harlow: Pearson Longman, 2005), 14.

35 'Roll of Honour,' The Outlook, 21 December 1915, in MS-0985-033/008, HL.

36 Tosh, Manliness and Masculinities, 35.

37 'Roll of Honour,' The Outlook, 21 December 1915, in MS-0985-033/008, HL.

${ }^{38} \mathrm{Ibid}$. See also Tosh, Manliness and Masculinities, 72-73.
} 
financial support from none. ${ }^{39}$ Soon after arriving in Crookston, George Stewart joined the committee planning the construction of the district's second public building: the Crookston Presbyterian Church. The church, a building 'not of the modern ornamental order, but...substantial and roomy', was opened in November 1899. ${ }^{40}$ As with almost all local initiatives, planning for the church had commenced with the formation of a local committee, followed by fundraising among local residents. After the church's opening, George Stewart remained involved as a congregation member and as a member of its managing committee. ${ }^{41}$ The Crookston Church was not only a place of worship, but also formed a significant gathering place for Crookston residents and the centre of the district's social and community life. ${ }^{42}$

Next door to the Church was the Crookston Athenaeum Hall. A flier in the G. H. Stewart memorial album advertises the Hall's 'Grand Opening Concert' to be held on August 21 1907, with musical performances by local residents followed by dancing, and funds raised from admission charges to benefit the Hall's Building Fund. ${ }^{43}$ From 1907, the Hall became the favoured location for the district's social events. As with the Church, the Hall's day-to-day organisation was in the hands of a committee of local farmers, among them George Stewart. Farming life required a good deal of cooperation between neighbours. Neighbouring farmers assisted each other during busy periods such as harvest, took turns with agricultural machinery such as mills, and bought or exchanged each other's stock and produce. Above this informal level of cooperation, farmers organised to represent their interests on the regional and national scales. ${ }^{44}$ Crookston was represented by a local branch of the Farmers' Union, predecessor of Federated Farmers, from at least 1902, and George Stewart occupied the role of its president from the time of its establishment until his death. ${ }^{45}$ The Farmers' Union lobbied government in the interests of farmers on the provincial and national level, and also represented farmers' views on issues of wider national interest. George Stewart became a member of the Otago Executive of the Union in 1909, and served as its

\footnotetext{
39 'Roll of Honour,' Tapanui Courier, 8 December 1915, in MS-0985-033/008, HL.

40 'Tapanui,' Otago Daily Times, 1 December 1899, 8.

41 George to Mary, 12 March 1899, MS-0985-048/001, HL. The Crookston church formed a single parish with the church in nearby Dunrobin, opened in 1892. Miller, Beyond the Blue Mountains, 159-160.

42 Members of the congregation took advantage of opportunities for socialising before and after church and gathered for regular Wednesday night church socials. After-church talks were the source of much of the Crookston gossip that George relayed to his siblings in his letters, via their aunt Annie Stewart who kept house for him. See for instance George to Mary, 23 February 1913, MS-0985-048/003, HL.

43 'Crookston Athenaeum Hall: Grand Opening Concert,' 1907, in MS-0985-033/008, HL.

44 Hamer, 'Towns in Nineteenth-Century New Zealand,' 18.

45 'Threshing Mill Strike,' Otago Daily Times, 1 May 1902, 8.
} 
president in $1910 .{ }^{46}$ George Stewart was also a committee member of the Tapanui Farmers' Club and Tapanui Agricultural and Pastoral society, founded in 1875. The Farmers' Club, which held its meetings in the Central Hall, Tapanui, also provided a forum for local farmers to meet, socialise and discuss farming topics. The annual A \& P shows, organised by the Club, were among the most important occasions in the district's social calendar, and drew impressive numbers of visitors from neighbouring areas and from across the Otago and Southland region. ${ }^{47}$

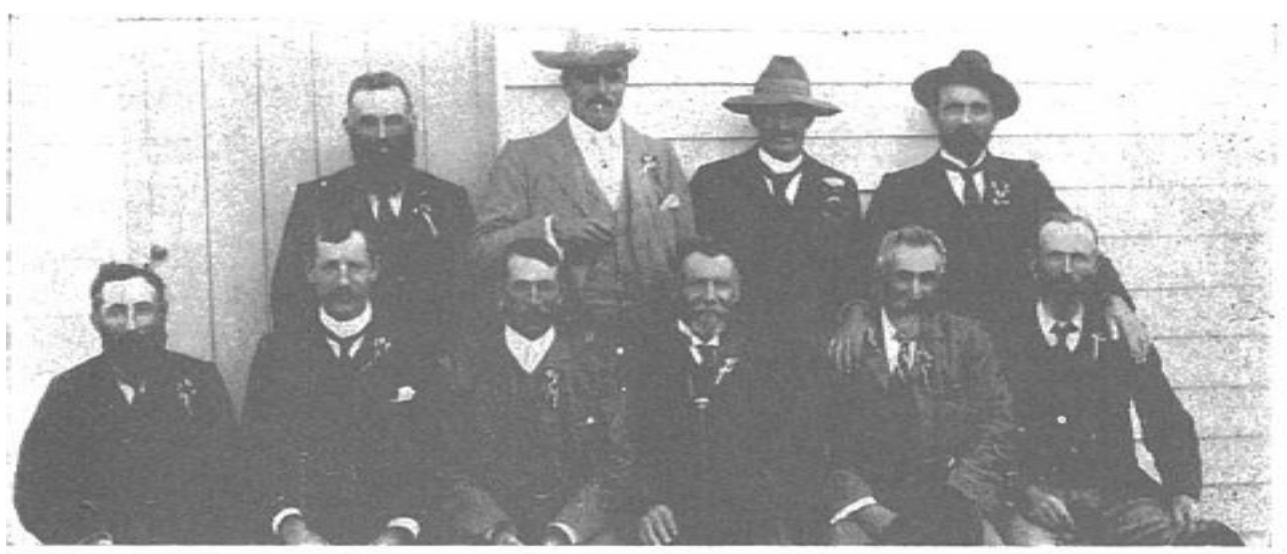

Tapanui Farmers' Club Committee, about 1902 Back row: David Black, Robert A. Rodger, Hugh Howat, David Fleming Front row: William Cullen, George H. Stewart, James Edgar, James Davidson, David Dickison, John McDuft

Figure 4.7: Tapanui Farmers' Club Committee c. 1902

Source: Millar, Beyond the Blue Mountains, plate x.

Volunteer regiments formed part of the fabric of rural life in the first decade of the twentieth century. George Stewart was a captain and founding member of the Kelso Mounted Rifles (KMR), reformed in 1912 as the $12^{\text {th }}$ Otago Mounted Rifles. The KMR formed part of a network of local volunteer troops that proliferated from the turn of the twentieth century in response to mounting anxieties about military readiness and Imperial defence, and were representative of a more widespread infusion of militarist and imperialist values into associational life in this period. Members of the KMR met regularly for exercises such as shooting practice and drill and competed against troops

\footnotetext{
${ }^{46}$ Miller, Beyond the Blue Mountains, 84; 'Farmers' Union,' Otago Daily Times, 9 September 1910, 8.

47700 people attended the Tapanui show in 1899, and by the late 1910s, the Tapanui show regularly attracted crowds of upwards of 2000 people. From 1910, Kelso had also established its own A \& P show.
} 
from surrounding districts in events such as shooting matches. ${ }^{48}$ The fact that members were required to supply their own horse, equipment and uniform and to pay a $f^{3}$ entrance fee imposed a degree of exclusivity on the troop. ${ }^{49}$ Their activities often overlapped with those of the church, with KMR members staging regular church parades on Sundays. Local regiments such as the KMR were connected to their regional organisation through annual training camps, lasting a week or more. ${ }^{50}$
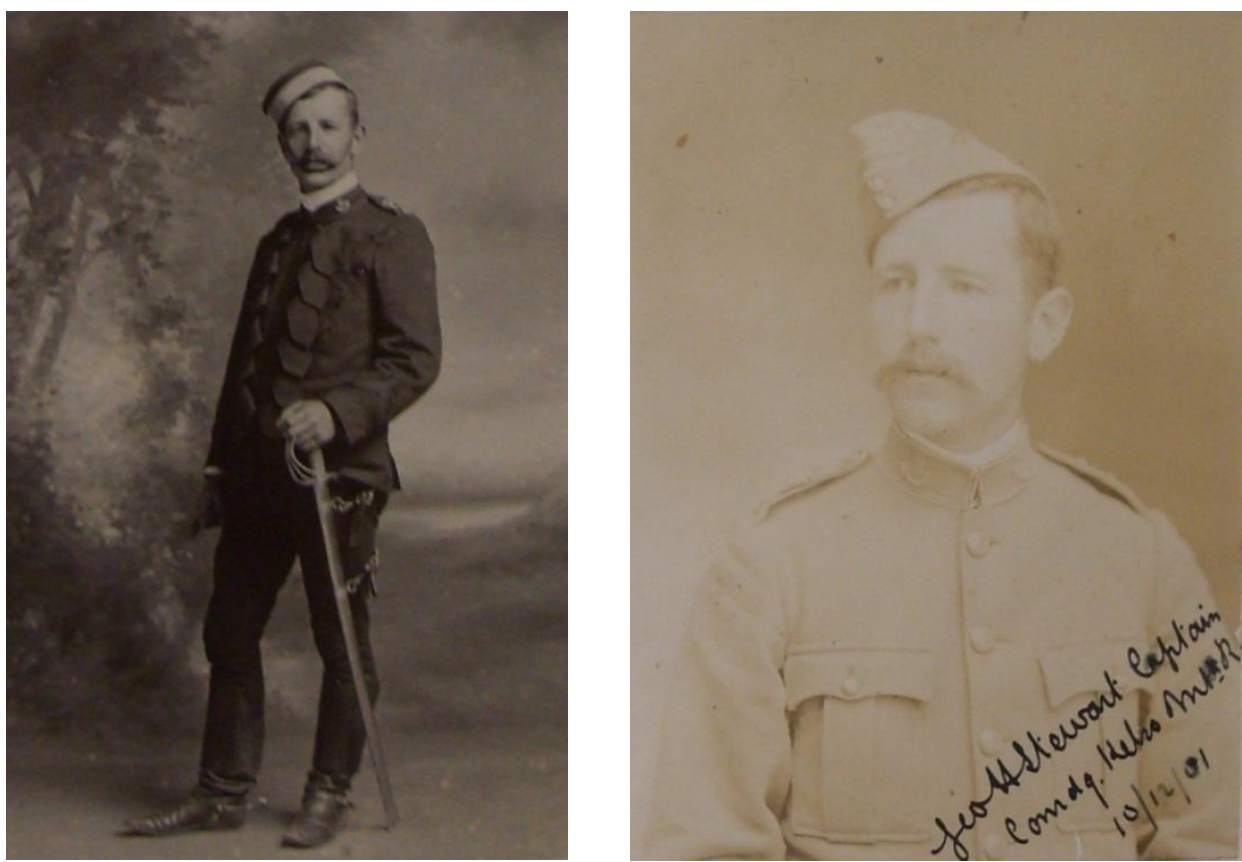

Figure 4.8: George Stewart in military uniform

Source: G. H. Stewart Memorial Album, MS-0985-033/008, HL.

George Stewart was the first Crookston soldier to die in the war. His death acquired an added dimension of significance for Crookston residents as the first local impact of the rapidly mounting death toll overseas. For local woman Jean Sim and her husband, reading of George's death in the Otago Daily Times had brought the reality of the war home for the first time. She wrote in her condolence letter: 'We never felt the war come more fully home to us, than we did when we read of his death in the "Times". Although so many of our brave boys have been taken, he is the first we have really known well,

\footnotetext{
48 George to Mary, c. 1910, MS-0985-048/003, HL; George to Mary, 6 May 1902, MS-0985-048/001, HL.

49 Miller, Beyond the Blue Mountains, 130.

${ }^{50}$ Ibid., 130-131. Melanie Nolan describes the volunteer corps camps in Canterbury as: 'as much social as educative occasions, with large numbers of visitors welcome, a canteen with smoke concerts, and singing and entertainments as well as divine service, drill and march-pasts'. Nolan, Kin, 156-157.
} 
and from Crookston. ${ }^{51}$ While George Stewart was not a typical Crookston farmer, he fitted within a cohort of local men who - although they may have lacked George Stewart's degree of wealth and influence - threw themselves into public duties with enthusiasm. ${ }^{52}$ These men peopled local committees, raised funds for community initiatives, and advanced their own and their district's interests through membership in local, regional, and national organisations. Their activities were markers of masculine respectability and a form of social capital. Participation in voluntary associations and societies has been seen by historians as a key feature of the development of middle-class male identity in the nineteenth century. ${ }^{53}$ The middle-class ideals of duty and disinterested service promulgated by such groups, together with their foundations of Christian faith, are crucial to understanding the shape that commemoration took in Crookston after George Stewart's death.

The indebtedness of commemoration to the gendered patterns of middle-class associational life can be illustrated through the efforts of Crookston residents to establish a Crookston 'Fallen Soldiers' Memorial' dedicated to the memory of George Stewart. In December 1915, Crookston residents met to consider the question of a memorial which they intended to stand in for the memory of George Stewart as well as any other Crookston man who might in future 'fall' in the war. ${ }^{54}$ As the Courier reported: it was felt by Crookston residents, to whom he was particularly well known, that something should be done to perpetuate his memory, and also the memory of all soldiers from Crookston who may give their lives for King and Empire.' This proposed memorial would be erected 'at some central position in Crookston' and the newly appointed memorial committee then called for subscriptions. ${ }^{55}$ The twelve men who formed the Fallen Soldiers' Committee were familiar identities from other Crookston institutions. Three members of the committee were also past or former members of the Crookston Church Committee. ${ }^{56}$ Six also belonged to the Crookston Athenaeum Hall Committee. ${ }^{57}$ Several belonged to the Crookston Patriotic Society. ${ }^{58}$ Only two members

\footnotetext{
51 Jean Sim to Mary, 2 December 1915, MS-0985-033/003, HL.

52 At the time of his death, George Stewart possessed a total wealth of $£ 15,000$, comfortably placing him within the ranks of the colonial 'rich'. See McAloon, No Idle Rich, 15; 'George Hepburn Stewart - probate file,' DAAD/9075/ 341/3386, ANZ.

${ }^{53}$ Davidoff and Hall, Family Fortunes, 416; Tosh, Manliness and Masculinities, 38.

54 'Proposed Fallen Soldiers' Memorial at Crookston,' Tapanui Courier, 22 December 1915, in MS-0985-033/008, HL. 55 Ibid.

${ }^{56}$ Secretary Paton Dunlop was also the secretary of the Crookston Church Committee. Robert Potts served on both committees, as did William Cullen.

${ }^{57}$ W. Pringle, Ian Revie, William Cullen, W. H. Lusk (junior), J. D. Fleming, Robert Potts. See 'Crookston,' Tapanui Courier, 22 November 1916.
} 
of the Fallen Soldiers' Committee were not also members of the Tapanui Farmers' Club. ${ }^{59}$ Other members with less of a distinguished track record in the district's associational life may have been motivated to join because they had sons or close relatives at the front. ${ }^{60}$ In forming a committee, advertising for community interest and subscriptions, and celebrating its unveiling, the designers of the Fallen Soldiers' Memorial thus followed the well-trodden path of earlier initiatives such as the church and hall, as well as that taken by other communities around the country in planning war memorials. ${ }^{61}$ It was the ideals of their middle-class male organising committee: duty, imperial service and their attempts to assert control through the informal power structures of their district's civic institutional life that came to the fore in local memorials such as Crookston Fallen Soldiers' Memorial. ${ }^{62}$ The Crookston Committees' plans were realised in 1919, when a modest Roll of Honour in plaster and wood was unveiled at a Returned Soldiers' Social at the Crookston Hall. By that stage, four more Crookston men had lost their lives in the conflict, out of a total of 31 of the district's men who had gone to war. ${ }^{63}$

\section{Christian communities of consolation}

The letters of sympathy received by George Stewart's family reveal the importance of a wider Christian community of shared faith and tradition in shaping the content of condolence letters and as a component of the support networks of bereaved families. Scholars of wartime grief such as David Cannadine and Pat Jalland contend that, during the war, conventional religion lost its power to comfort the bereaved. ${ }^{64}$ According to Jalland, the war dealt 'a shattering blow to the way families had habitually coped with dying and with grief for more than a century' causing 'a total breach with the Victorian way of death among the middle and upper classes' ${ }^{35}$ By contrast, the condolence letters received by George Stewart's family point to the enduring power of faith as a source of consolation for bereaved relatives, at least at this stage in the war. Just over 32 per cent of the letters in the collection contained religious ideas. One of the most common

\footnotetext{
58 Ian Revie, W. H. Lusk junior, David Fleming, J. Pullar.

59 'Tapanui Farmers' Club,' Tapanui Courier, 4 October 1916.

${ }^{60}$ Committee members D. and F. Fleming, W. Pringle, Peter Sim and A. Mackay were probably in this situation.

61 Maclean and Phillips, The Sorrow and the Pride, 91.

62 While men usually comprised the organising committees for such memorials, women were prominent as fundraisers for local memorials in many communities. See Maclean and Phillips, The Sorrow and the Pride, 92 . The families of the bereaved were also significant contributors to public subscriptions for memorials. Hunter, “'Sleep now dear Ernie,", 39.

63 'Returned Soldiers' Social at Crookston,' 1919, Tapanui Courier in MS-0985-033/008, HL.

${ }^{64}$ Cannadine, 'War and Death,' 218; Jalland, Death in the Victorian Family, 372.

65 Jalland, Death in the Victorian Family, 372-373.
} 
religious sentiments voiced by these letters was to express the conviction, directed at bereaved relatives, that God would give them the comfort and strength to bear their loss. ${ }^{66}$ Forty four of the 76 letters containing religious content, or around 58 per cent, expressed variants of this idea. M. A. Gaze, a former neighbour of Rachel at Temuka wrote: 'The war is a cruel war \& when will it end. What hundreds \& thousands of our best $\&$ bravest have gone $\&$ never more to return, but God will bless you all \& heal the broken hearted. ${ }^{97}$ 'God give you strength dearest friend to bear this awful cross', wrote Mary Stewart Bartleman, a distant cousin. ${ }^{68}$ H. B. Goertz, a friend of Elizabeth's and the minister who had solemnized her marriage to George, wrote that Christ's own suffering provided an example for grieving relatives to follow:

Dear friend! Your life has been full of tragedy, and it would not be surprising if you felt that you have had more than your share of suffering. Even Christ at times, felt His load more than He could bear - and petitioned for release - and He was answered by the Angelic Ministers who "Strengthened Him to Endure!" Even so will you be strengthened if you will still endeavour to Carry the Cross: and our life's tragedies pale into insignificance when we catch a glimpse of the Divine Sufferer - the Man of Sorrows. ${ }^{69}$

Others wrote of the importance of faith and the need to trust in Providence and in God's higher purpose, however incomprehensible His ways might seem to humans. Jean M. Sim wrote 'God has some great purpose in this terrible war, and we must try to trust in Him though it is hard to see the light sometimes. ${ }^{, 70}$ Crookston schoolteacher and postmistress Jane M. Farquharson wrote: 'Will you try to think that it was God's love that gave such a brother as he was to you. If his love could bestow a precious gift upon you for a season, you will not murmur or doubt the love which has taken him from all the horrors of trench warfare to be with Himself...He knows what is best altho' we cannot see the way - but we shall know hereafter what it all meant. ${ }^{71} \mathrm{D}$. Wright, Mary and William's neighbour on Heriot Row in Dunedin, wrote: 'The providence

\footnotetext{
${ }^{66}$ According to Jalland, the conviction that 'all deaths were the will of God, and that he would send the strength and courage to bear the sorrow and pain' was common among Victorian widows. Ibid., 240.

${ }^{67}$ M. A. Gaze to Rachel, 6 December 1915, MS-0985-033/003, HL.

68 Mary Stewart Bartleman to Mary, 1 December 1915, MS-0985-033/005, HL.

${ }^{69}$ H. B. Goertz to Elizabeth, 6 December 1915, MS-0985-033/002, HL.

${ }^{70}$ Jean Sim to Mary, 2 December 1915, MS-0985-033/003, HL.

${ }^{71}$ Jane H. Farquharson to May, 5 December 1915, MS-0985-033/004, HL.
} 
which strikes down such a brother and such a splendid citizen is indeed a great mystery. May the God of all comfort sustain you in the dark and cloudy day. ${ }^{, 72}$

As with the condolence letters sent by nineteenth-century Otago settlers, described in Alison Clarke's work, belief in the afterlife formed a 'pervasive' feature of condolence letters received by the Stewart family. ${ }^{73}$ Twenty seven of the 76 condolence letters which included some religious content, or over 35 percent, also included references to heaven. At the most basic level, references to heaven entered into condolence letters in common euphemisms for death such as 'gone on before' or 'called to his last home'. ${ }^{74}$ Other letter writers, like Elizabeth Stewart, looked forward to family reunions in heaven. Eight correspondents ( 7 female and one male) pointed to this form of consolation. A. Turton wrote 'It is terribly sad, too, for his young wife... They had had such a short time of happiness together, but they will meet again - all this sorrow has made that clear to us - the next world is very near \& I am sure our loved ones are permitted to help us, \& we know they have passed from Death into life. ${ }^{75}$ Another member of the Stewart family wrote to Mary of the consolation of knowing that the bereaved would meet their loved ones again in heaven: ' $[\mathrm{H}] \mathrm{e}$ has been taken away from this earthly life, but only to enter on a far grander nobler life... Oh this terrible war... What a sad Christmas this will be for most people - there are so few who have not had saddened hearts by it - but we must not grieve, as those who have no hope - for as Christ died \& rose again from the dead so shall those dear to us do \& we shall all be reunited, where there is no more sorrow or Parting - but, for this Certainty - our life now, would be a sad one. ${ }^{76}$ This evidence affirms Jalland's conclusion that the idea of reunion with deceased family members formed a 'primary consolation' of heaven for Victorian and Edwardian families. ${ }^{77}$

\footnotetext{
72 D. Wright, 4 December 1915, MS-0985-033/003, HL.

73 Alison Clarke, “'Tinged with Christian Sentiment”: Popular Religion and the Otago Colonists, 1850-1900,' in Christianity, Modernity and Culture: New Perspectives on New Zealand History, ed., John Stenhouse (Adelaide: ATF Press, 2005), 126-127. For the attitudes towards heaven of nineteenth-century Otago colonists, see Alison Clarke 'Heavenly Visions: Otago Colonists' Concepts of the Afterlife,' Journal of Religious History 30, no. 1 (February 2006): 2-17. 74 A. Turton to Mary, 1 December 1915, MS-0985-033/003, HL; Annie McKay to Rachel, 6 December 1915, MS0985-033/003, HL. 'Gone on before' probably refers to the saying 'Not lost, but gone before', a common Victorian euphemism for death which featured on many gravestones. See Michael Wheeler, Death and the Future Life in Victorian Literature and Theology (Cambridge: Cambridge University Press, 1990), 376, footnote 10.

75 A. Turton to Mary, 1 December 1915, MS-0985/033/003, HL.

${ }^{76}$ Mary Stewart to Mary, 5 December 1915, MS-0985-033/006, HL. It is unclear whether the author of this letter was her stepmother or her paternal aunt of the same name.

77 Jalland, Death in the Victorian Family, 271. Michael Wheeler writes: 'Perhaps the most characteristic Victorian ideas of heaven are of a place in which family reunions and the "recognition of friends" are to be achieved after death, and (more radically Romantic) of a site in which lovers are reunited as couples.' Wheeler, Death and the Future Life, $120-121$. Alison Clarke describes 'the hope of a future heavenly reunion with their departed friends and relatives' as 'the greatest comfort' for bereaved Otago settlers in the nineteenth century. Clarke, 'Heavenly Visions,' 10.
} 
Other scholars point to ideas of heaven as a place of work or service as pervasive features of nineteenth-century visions of the afterlife. ${ }^{78}$ Six condolence letter writers expressed this view. Family friend Christine Mackerras wrote that George had been called to 'higher services' and had been chosen to do 'the work of [his] master on higher planes'. ${ }^{79}$ Reverend Rutherford Waddell wrote: 'it is good to think that life is a continuity \& that he has carried on his great gifts \& acquirements into some other high sphere, ${ }^{80}$ Family friend Eva Robinson wrote: '...[O]ne's pride in their noble work \& sacrifice, in giving their lives for their country, does help very much, \& I am quite sure that these brave spirits are still carrying out work for God. ${ }^{81}$ A further seven letters contained less specific references to heaven, simply noting that relatives would find consolation in the knowledge that their husband or brother had commenced upon a new phase of life in a 'happier' or 'better' sphere. The view that soldiers would be granted automatic entry to Heaven by virtue of their military service alone was expressed by two condolence letter writers. A Temuka acquaintance of Rachel's wrote: 'There is surely consolation in feeling that every one who falls on our side, dies doing his duty to his God. And that "Enter Good and Faithful Servant" will be his reward. ${ }^{82}$

Part of the shared religious language invoked by the authors of condolence letters involved quoting remembered or copied lines from the Bible, hymns, prayers books or poetry. As the previous chapter suggested, the circulation of such religious texts formed a common currency for the bereaved in times of loss. The Reverend H. B. Goertz included an extract from the hymn 'They whose course on Earth is O'er' in his condolence letter: 'With them still our hearts we raise; Share their work and join their

\footnotetext{
${ }^{78}$ Colleen McDannell and Bernhard Lang argue that 'late nineteenth-century Christians, for the most part, imagined a heaven of growth and activity'. Colleen McDannell and Bernhard Lang, Heaven: A History, $2^{\text {nd }}$ ed. (New Haven: Yale University Press, 2001), 277. Jalland's argument as to the importance of heaven as a place of family reunion is posed as a counter-argument to McDannell and Lang.

${ }^{79}$ Christine MacKerras to Mary, 10 July 1916, MS-0985-033/001, HL.

${ }^{80}$ Rutherford Waddell to William, 1 December 1915, MB-391-3/18, MBL. Rutherford Waddell was a Presbyterian Minister and social reformer whose expose of 'sweated' labour in factories led to the 1890 Royal Commission on Sweating. Waddell had been a friend of William Downie Stewart the senior. See Ian Breward. 'Waddell, Rutherford biography,' DNZB, updated 30-Oct-12, URL: http://www. TeAra.govt.nz /en/biographies /2w1/waddellrutherford, accessed 18 March 2013.

${ }^{81}$ Eva Robinson to Rachel, 2 December 1915, MS-0985-033/003, HL. Eva Robinson was a married daughter of the wealthy Dunedin Turton family.

82 Edmund Ames to Rachel, 7 December 1915, MS-0985-033/003, HL. The view that soldiers would be granted automatic entry to Heaven was widely espoused by clergymen during the First World War. See Allan Davidson, 'New Zealand Churches and Death in the First World War,' in New Zealand's Great War, eds., Crawford and McGibbon, 458-460. The ministers at two of the three church memorial services held for George Stewart expressed variants of this idea. At the Crookston service Reverend Hercus stated: 'They were mourning the loss of a good and true man, one who had died as he had lived, bravely doing his duty. He had been true unto death and his reward would be a crown of life'. 'The Late Lieut-Col. Stewart,' Tuapeka Times, 15 December 1915, in MS-0985-033/008, HL. At the Heriot service, the Reverend A. S. Moffatt stated that, "To such a one death was not retirement but promotion. He had laid down his life for his King and his nation, and for those present, and had entered into his exceeding great reward.' 'The Late Lieutenant-Colonel Stewart,' Tapanui Courier, 22 December 1915, in MS-0985-033/008, HL.
} 
praise; Rend'ring worship, thanks \& love; To the Trinity above. ${ }^{93}$ The Reverend John Collie included in his condolence letter to Mary an extract from Tennyson's 1833 poem 'To J.S.': 'His memory long will live alone, In all our hearts, as mournful light, That broods above the fallen sun, And dwells in Heaven half the night ${ }^{84}$; and to Elizabeth a line from his 1869 'Dedication': 'till God's love set thee at his side again'. ${ }^{85}$ Though more commonly found in letters from clergymen, such references also featured in letters by lay people. Annie Turton quoted the line 'Death hides but it does not divide', echoing the verse: 'Death doth hide, but not divide; Thou art but on Christ's other side; Thou Art with Christ and Christ with us; In Christ united still are we. ${ }^{86}$ Frances G. Maitland sent an extract from 'The Gospel of Hope' by J. R. Lowell, commenting: 'Do you know J. R. Lowell's commemoration ode - the enclosed part of it is I think very beautiful'. ${ }^{87}$ Dr. P. A. Lindsay cited lines from Norman Maclean's 1915 The Great Discovery; the Biblical story of Job; a speech on faith given by a Quaker to an English congregation, and poet Robert Browning's Epilogue to Asolando: 'greet the unseen with a cheer ${ }^{98}$ Lindsay was also the only letter writer to draw specific attention to the family's Scottish ethnicity: claiming that the Celtic races (whom he counted himself and William among), had a special capacity for sensing the invisible pageant that is the mystic counterpart of visible things, 89

Overall, there was not a large difference in the proportion of letters with religious content sent by women and men. Thirty four per cent of letters by female correspondents contained religious references, slightly higher than the 31 per cent of letters by men. The sex of a letter's recipient appears to be a more important determinant of the religious content of condolence letters. Of those letters addressed to Rachel and Mary, 32 and 31 per cent respectively contained religious content, and over half of letters addressed to Elizabeth contained a religious component. By contrast, only 19 per cent of the letters addressed to William contained religious content, in spite of his strong religious convictions and lifetime association with the Presbyterian church. This was likely in part a reflection of the more secular values of the urban professional men,

${ }^{83}$ H. B. Goertz to Elizabeth, 6 December 1915, MS-0985-033/002, HL.

${ }^{84}$ Rev. John Collie to Mary, 30 November 1915, MS-0985-033/007, HL.

${ }^{85}$ Rev. John Collie to Elizabeth, 30 November 1915, MS-0985-033/002, HL.

86 A. Turton to Rachel, 1 December 1915, MS-0985-033/003, HL.

${ }^{87}$ Frances G. Maitland to Mary, 2 December 1915, MS-0985-033/003, HL. American romantic poet James Russell Lowell's 'Ode Recited at the Harvard Commemoration', 21 July 1865.

88 P. A. Lindsay to William, 20 December 1915, MS-0985-003/011, HL. Norman Maclean, The Great Discovery

(Glasgow: J. Maclehose and Sons, 1915); Robert Browning, Asolando, Fancies and Facts (Boston; New York: Houghton, Mifflin and Company, 1890).

89 P. A. Lindsay to William, 20 December 1915, MS-0985-003/011, HL. 
public officials and parliamentarians prominently represented in William's networks. It may also reflect the Victorian middle-class view of women as innately more spiritual than men and thus more receptive to such religious consolations.

Another way in which religion played a significant role in shaping the form that mourning communities took is when churches formed sites of commemorations for the war dead. Crookston Church was the site of the first and largest of a series of local gatherings dedicated to the memory of George Stewart. On the evening of the service, Sunday 12 December 1915, the church was packed to capacity. Among those present were about forty members of the KMR, for whom special seating had been reserved. ${ }^{90}$ The service had been advertised in the Tapanui Courier the week prior, and drew large numbers of local residents. ${ }^{91}$ The two newspaper reports of the event agreed on the large size of the crowd who attended, and to its positive reflection on the deceased's popularity in his district. The Tapanui Courier journalist who attended the service reported that: 'the high regard and love in which the deceased soldier was held was plainly manifested by the very large audience at the service. Every seat in the building, which is capable of holding between 200 and 300 persons, was occupied, and some of the late-comers had difficulty in finding even standing room in the rear. ${ }^{92}$ To add to the occasion's sombre tone, the organ and choir rails had been draped in black, and a flag was also stretched across the front of the rails. 'The large hushed gathering and the symbols of mourning made the scene an impressive one', the Tuapeka Times' correspondent reported. ${ }^{93}$ Similar scenes were repeated at services held at churches in neighbouring Kelso and Heriot later that month.

It was likely at the Crookston Church memorial service that local residents first mooted the idea of having a plaque and portrait installed in George Stewart's memory. As local farmer Robert Potts explained to Mary: 'The people in Crookston intend to do something to perpetuate his memory. Several sugestions [sic] have been made, but I thing [sic] the best proposed so far is to erect a tablet in the church and to get a photo of him enlarged and hung in the hall. ${ }^{94}$ Potts and Mary communicated further on the matter of the plaque and portrait during 1916 and Mary agreed to Potts' request to

90 'The Late Lieut-Col. Stewart,' Tuapeka Times, 15 December 1915, in MS-0985-033/008, HL.

91 'Memorial Service at Crookston,' Tapanui Courier, 15 December 1915, MS-0985-033/008, HL.

92 Ibid. A similar report appeared in the Otago Witness. 'Memorial Service at Crookston,' Otago Witness, 22 December $1915,52$.

93 'The Late Lieut-Col. Stewart,' Tuapeka Times, 15 December 1915, in MS-0985-033/008, HL.

94 R. Potts to Mary, 20 December 1915, MS-0985-033/001, HL. 
donate both items on behalf of George's wife Elizabeth: a move that demonstrated a family's ability to pay as a factor in the erection of individual memorials. ${ }^{95}$ Mary presented the enlarged portrait of George to the Hall in March 1916, while the plaque was unveiled in the Crookston church the following January. Locals from Crookston and neighbouring districts were well represented at the plaque's unveiling. ${ }^{96}$ Speaking at that event, Reverend John Collie hoped that for future generations of church-goers for whom George Stewart would be 'but a name', the plaque's 'mute record' would testify to the memory 'of one who served his generation worthily and well, and at last laid down his life in his country's cause' and thus might 'in after days quicken some heart to a sense of the honour due to public good, and so help nourish the spirit of disinterested service. ${ }^{97}$

In some descriptions of George Stewart's life, a specifically Christian variant of manliness is evident. Speakers at the Crookston and Kelso services, for instance, praised George Stewart for keeping the sabbath. He was, Reverend Hercus told those gathered at the Crookston service, 'old fashioned enough to reverence the sanctity of the Sabbath and endeavoured to keep it holy'. ${ }^{98}$ The Reverend Thomas Paulin, in the course of travelling the district to gather materials for the Kelso service had, 'found the whole district moved' by his death: 'his gentleness \& kindliness of heart \& generosity were his peculiar hallmark, \& a friend and neighbour of mine said to me on Saturday night: "There never was a whiter man.",99 The description of 'whiteness', conveying a cluster of attributes such as uprightness, sexual purity, decency, and abstinence as well as echoing racial categories, also featured in several other condolence letters. ${ }^{100}$ Annie McKay, George's employee at Westwood wrote: 'I know quite well you all feel the loss of so good \& pure a man! The whitest man on earth!101 George's close friend, J. D.

\footnotetext{
95 In Britain, many middle-class families also possessed the means to create individual memorials to their dead and these commonly took the form of plaques or stained glass windows placed in local churches. McCartney, Citizen Soldiers, 246.

96 'Memorial Tablet to Late Colonel G. H. Stewart,' Tapanui Courier, c. January 1917, in MS-0985-033/008, HL. 97 Ibid. Like most community occasions, the 1917 unveiling ceremony also served a dual fundraising purpose, with f8. 12. 7d being collected in aid of the Red Cross Fund. 'Memorial Tablet to Late Colonel G. H. Stewart,' Tapanui Courier, c. January 1917, in MS-0985-033/008, HL.

98 'The Late Lieut-Col. Stewart,' Tuapeka Times, 15 December 1915, in MS-0985-033/008, HL; 'The Late LieutenantColonel Stewart,' Tapanui Courier, 22 December 1915, MS-0985-033/008, HL.

99 'Thomas Paulin to Elizabeth, 7 December 1915, MS-0985-033/002, HL.

100 Elizabeth's brother Dr William Herbert wrote 'I have no doubt you have golden memories of the happy time you had before duty took that fine soldier \& white man who loved away to the front'. W. E. Herbert to Elizabeth, 1 December 1915, MS-0985-033/002, HL. Annie McKay, who with her husband was employed to manage Westwood in George's absence wrote: 'It is comforting to hear the way everyone speaks of him "the whitest of men" always time for a kind word to everyone’. Annie McKay to Rachel, 6 December 1915, MS-0985-033/003, HL.

101 Annie McKay to Mary, 2 December 1915, MS-0985-033/005, HL.
} 
Munro wrote: 'he lived a clean honest \& faithful life \& men like him one does not like to see called away'. ${ }^{102}$

\section{Duty, service, and sacrifice}

In addition to these Christian consolations, letters of sympathy commonly contained references to ideals such as duty, service, or sacrifice. Fifty three of 234 condolence letters, or 22 percent, contain references to one or more of these terms. While both men and women referred to such ideals in their condolence letters, they were twice as likely to appear in letters written by men, with 32 per cent of men compared with 16 per cent of women referring to duty, service or sacrifice in their letters. The form that references to duty took also varied between condolence letters. A number of condolence letters highlighted George Stewart's attributes as a soldier or officer. Nine condolence letter writers described George Stewart in heroic or chivalric terms as a brave, noble or gallant soldier. 'I can scarcely believe that that strong man \& gallant soldier has gone', wrote family friend G. L. Denniston. ${ }^{103}$ Another variant of military masculinity appeared in references to George Stewart's qualities as a popular officer who commanded the love and respect of his men. Twenty seven letters included this type of idea. 'The love \& absolute trust he inspired in his men will be his most lasting monument' wrote Grace Davis, the mother of a soldier who had been under George Stewart's command: 'Tho' he has passed from the actual warfare I feel he still lives in the example \& spirit that he infused into his men'. ${ }^{104}$

By the late nineteenth century the heroic soldier had merged with the rise of popular imperialist sentiment to form an ideal masculine type only truly fulfilled in combat. ${ }^{105}$ As British historian Graham Dawson has written, "A "real man" would henceforth be defined and recognized as one who was prepared to fight (and, if necessary, to sacrifice his life) for Queen, Country, and Empire'. ${ }^{106}$ Military masculinity reached its apogee in death in combat, and it is not surprising that references to George Stewart's qualities as a soldier frequently appear in in connection to his death. ${ }^{107}$ Robert Gilbert Baxton wrote to William: 'It must be a great consolation to know, that he died -

\footnotetext{
102 J. D. Munro to Mary, 10 January 1916, MS-0985-033/001, HL.

103 G. L. Denniston to Mary, 30 November 1915, MS-0985-033/003, HL.

104 Grace Davis to Mary, 1 December 1915, MS-0985-033/001, HL.

105 Graham Dawson, Soldier Heroes: British Adventure, Empire and the Imagining of Masculinities (London: Routledge, 1994), 1 
a soldier - at his post, doing his duty to his King \& Country. A death - when it has to come - that is to be envied by all'. ${ }^{108}$ A friend of Mary's, Kathleen Ulrich, wrote: 'I suppose to die on active service is a death we would all choose but still it's very hard on those left behind'. ${ }^{109}$

The nature of George's death - of illness in hospital rather than in the midst of battle, and with his wife rather than his comrades by his side - complicated any attempts by his friends and family to insert his death into heroic narratives. Three condolence letter writers expressed regret that George had not died in combat. William Henry Moore, a cousin, wrote: 'It seems so sad that George who was always prepared to fight $\&$ if necessary to die fighting for his country should pass away through illness'. ${ }^{110}$ However, a greater number of correspondents (seventeen in total) felt that the fact his death occurred while on active service was more important than its specific details. J. J. Clark, mayor of Dunedin and a personal friend of Mary's wrote: 'Your consolation is that your Brother died doing his duty - as heroically as if he fell on the field of battle'. ${ }^{111}$ An equal number of correspondents - seventeen in total - voiced gladness that George's death occurred in hospital with his wife beside him. This view more closely approximated the ideal civilian death - painless and surrounded by family - than the heroic death of a soldier. Eliza Bagshaw, former housekeeper to George, wrote: 'oh what a realief [sic] to get your letter yesterday telling me that Mrs Stewart was with her husband at the last, and that he passed quietly away in his bed, and not tortured by those awful feinds [sic]'. ${ }^{12}$ A Stewart cousin, J. Lawson, wrote: 'We were all thankful when we heard that you were with him, to soothe, \& comfort him in his last hours. I sincerely hope he did not suffer much. ${ }^{113}$

Previous studies of First World War condolence letters have identified celebrations of heroic sacrifice and military ideals of death as the dominant features of such letters. However, such studies have usually concentrated solely upon letters of sympathy written by the deceased's fellow soldiers or officers, rather than those drawn

\footnotetext{
108 Robert Gilbert Baxton to William, 1 December 1915, MB-391/3/18, MBL.

109 Kathleen Ulrich to Mary, 5 December 1915, MS-0985-033/007, HL.

110 W. H. Moore to William, 1 December 1915, MB-391-3/18, MBL.

111 J. J. Clark to Mary, 30 November 1915, MS-0985-033/004, HL.

112 Eliza Bagshaw to Mary, 12 December 1915, MS-0985-033/006, HL.

113 J. Lawson to Elizabeth, 19 December 1915, MS-0985-033/006, HL.
} 
from civilian communities of mourners. ${ }^{114}$ Meyer, who does include letters written by civilians in her analysis of war-time letters of condolence, has nevertheless found that such letters celebrated men's military attributes at the expense of their civilian lives and qualities. ${ }^{115}$ The same was not the case, however, in the condolence letters received by George Stewart's family after his death. While 36 correspondents highlighted George Stewart's attributes as a soldier or officer in their condolence letters, 82 described his qualities as a friend, colleague, family man or neighbour. In praising George Stewart's action in following the path of military duty, many condolence letter writers framed his action as the final episode in a lifetime committed to service. Mungo Watson, a former teacher of George's at Otago Boys' High School, wrote in his condolence letter that George's actions in volunteering for military service were consistent with the sense of duty he had displayed as a high school pupil and since leaving school. He was, he wrote:

a level headed straight going boy who did good honest work and whose conduct was always above reproach one you would have expected in after years to act always with a strong sense of duty. I have heard much of him since - of his public spirit, his unselfishness, his great usefulness to his district and the high estimation in which he was held as an honoured kind hearted gentleman. He [was] just the one to answer at once the call to service which so many seem not to hear \& he has done his duty. ${ }^{116}$

In addressing the family, neighbours and friends who attended George Stewart's memorial service at Crookston Church in December 1915, Reverend Hercus spoke of George Stewart as a man who had 'in every respect...done his duty': 'to his home (everyone who had enjoyed the privilege of his hospitality knew what a bright and happy home his was) to his district, and to his King and Country'. ${ }^{117}$

Hercus's speech made no reference to the contradictions inherent within the various claims on men's duty that he outlined. However, as the author of George Stewart's obituary in the Outlook acknowledged more explicitly, all calls to duty were not

\footnotetext{
114 Roper focuses on the role of soldiers and officers in conveying descriptions of soldier's deaths to their families through condolence letters. See Roper, The Secret Battle, chapter five. Damousi emphasises the centrality of heroic narratives of sacrifice in the letters soldiers wrote to the families of their comrades. See Damousi, The Labour of Loss, 15-16.

115 Meyer, Men of War, 89.

116 Mungo Watson to William, 1 December 1915, MB-391-3/18, MBL.

117 'The Late Lieutenant-Colonel Stewart,' Tapanui Courier, 22 December 1915, MS-0985-033/008, HL.
} 
equal. Instead there existed a hierarchy in which the call of military service ultimately overrode the parochial claims of district or the domestic obligations of family. None can fully know, but those can partly judge who knew something of the devotion of his home life, what it meant to him to go to the front after little more than two years of married life. He went, not lightly, because going took him from all that he loved so deeply, but because it was his duty to go'. ${ }^{118}$ Or as William's friend J. W. Johnson put it: 'He like many others unselfishly sacrificed the comforts of home life to answer his country's call, and right nobly was his duty carried out'. ${ }^{119}$ Thus the apparent tensions between men's competing responsibilities could be resolved through the 'service' versus 'selfishness' dichotomy outlined in chapter one. Rather than negating the personal importance of his family ties, George Stewart's decision to follow the path of duty by going to war was seen as all the more admirable because of the strength of his domestic attachments. It was George Stewart's willingness to put duty before his personal interests that attested to the strength of his allegiance to that duty.

\section{Communities of mourning}

Circles of the bereaved, as this chapter has previously argued, drew heavily from forms of community already in existence before the war. However, the mass experience of bereavement during the war also created new communities of mourners, united by their shared experiences of loss. Some condolence letter writers made explicit mention of the Stewart family's membership in a wider community of families mourning lives cut short by war. The Stewarts' half-sister Ethel wrote: 'As this Xmas time draws near one realises that there are few homes that have not been saddened by the loss of dear ones \& War seems very real when it is ones own. ${ }^{120}$ Nevertheless, while acknowledging that George Stewart's death represented only one among many, correspondents also recognised that the knowledge that their experience was shared did not diminish a family's sorrow at their own loss. As Mary's friend Bee Barker wrote: 'What can I say to comfort you, only that I know so well what you are going through. I think of you all the time. Oh my dear,

\footnotetext{
118 'Roll of Honour,' The Outlook, 21 December 1915, in MS-0985-033/008, HL. John Collie's condolence letter to Elizabeth expressed a similar sentiment. 'The breaking of home ties in answer to the call of duty meant more to him than it does to most, \& it was only a very real sense of duty that led him to do it'. John Collie to Elizabeth, 30 November 1915, MS-0985-033/002, HL. The similarities between the Outlook obituary and condolence letters and sermons written by Collie suggest that he was the author of the obituary.

$119 \mathrm{~J}$. W. Johnson to Mary, 2 December 1915, MS-0985-033/005, HL.

120 Ethel Nisbet to Mary, 19 December 1915, MS-0985-033/002, HL.
} 
my dear, it does not help one bit to know there are hundreds of others going through the same thing. When it comes to oneself one can only think of self. ${ }^{, 121}$

Condolence letters forged a sense of kinship among soldiers' families through providing a space in which individuals could share their anxiety about the fate of soldier relatives - a phenomenon that Joy Damousi describes as 'a collective experience of anticipating mourning. ${ }^{122}$ Mungo Watson wrote to William in his condolence letter: 'One of my own sons has been dangerously ill in Egypt for nearly three months after taking part in hard fighting on the peninsula with the fifth squadron \& spending weeks in the trenches. However our last cables are more encouraging and we begin to hope that we may soon see him back again. ${ }^{123}$ A colleague of William's, G. A. Lewin, whose son had been in same troopship as George, wrote of his and his wife's anxieties over their own son: 'This cruel war is indeed taking a heavy toll $\&$ those near and dear to so many of one's friends that our condition is one of intense anxiety as to what any day may bring in the way of ill tidings. ${ }^{124}$ Another friend wrote: 'I mourn with you in your sorrow. I can enter into your feelings, having lost a boy of my own in Egypt'. ${ }^{125}$

But the communities of mourning based on anticipated or actual wartime losses proved to be porous, and also admitted individuals mourning civilian deaths. ${ }^{126}$ Dolly Neill, whose sister had died in 1913, wrote: 'I have been through the deep waters \& know all it must mean to you dear. ${ }^{127}$ The Stewarts' cousin Jessie Guthrie wrote: 'Well can I feel with you in these dark hours, having gone through it all. Charlie was just the same kind of man. Bright \& lovable \& was taken so swiftly in the prime of his life. We can only try to live as they would have us so that we may be able to join them by $\&$ bye. ${ }^{128}$ Her husband Charles Guthrie had been killed in a motor accident in 1913, leaving Jessie a widow and their two young children fatherless. 'It is so hard to understand the passing of these fine men', she wrote in another condolence letter: 'I try

\footnotetext{
121 Bee Barker to Mary, c. December 1915, MS-0985-033/007, HL.

122 Damousi, The Labour of Loss, 19.

${ }^{123}$ Mungo Watson to William, 1 December 1915, MB-391-3/18, MBL.

124 G. A. Lewin to William, 1 December 1915, MB-391-3/18/ MBL. Lewin's son James Henry Lewin survived the war. 'Lewin, James Henry - personnel file,' AABK-18805-W5544-15/0067950, ATL.

125 (name illegible) to William, 1 December 1915, MB-391/3/18, MBL.

126 In the British context, Jessica Meyer also notes that the civilian bereaved could 'gain access' to the circles of mourning created by the war, but also states that only those mourning military deaths 'were able to express sympathy without equivocation'. Meyer, Men of War, 76. This was not so in the case of the condolence letters sent to George Stewart's family.

127 Dolly Neill to Mary, 1 December 1915, MS-0985-033/007, HL. Beryl (Molly) Neill took her own life in 1913, aged 33. See 'Sudden Death,' Fielding Star, 29 September 1913, 3.

${ }^{128}$ Jessie M. Guthrie to Elizabeth, 12 December 1915, MS-0985-033/002, HL.
} 
always to remember Gods [sic] in the heavens \& alls [sic] well. ${ }^{129}$ Thus the networks of support created by those bereaved by war deaths could also encompass those mourning deaths in civilian life.

Another way in which those who mourned George Stewart's death participated in a larger community of mourners was through the various gatherings organised to honour George Stewart's life and death. A wide variety of such commemorative gatherings are documented in the G. H. Stewart memorial album. References to the passing of a series of minutes of sympathy at meetings of organisations with which George was associated in life suggest that middle-class associational culture could provide forums for men to express feelings of loss in structured settings which buttressed 'their commitment to Victorian values of self-restraint'. ${ }^{130}$ The gatherings at church and hall organised to commemorate George Stewart also promoted a collective sense of grief through providing opportunities for those who knew George to speak to his family members, to exchange memories, or to share their own fears over loved ones away at war. The meanings individuals may have attached to such gatherings, or to memorial objects such as the Crookston Fallen Soldiers' Memorial, were likely, as Winter writes, to have been 'highly personal' and variable. ${ }^{131}$ The places where George Stewart was remembered did not represent the district's associational life in its entirety. Fraternal societies such as Masonic and Oddfellows' Lodges, local sporting clubs, music groups and Boy Scout troops all represent other potential 'sites of memory' for local soldiers, with which George Stewart had no involvement. ${ }^{132}$

\footnotetext{
129 Jessie H. Guthrie to Rachel, 7 December 1915, MS-0985-033/003, HL.

130 Damousi, Labour of Loss, 52. The following organisations passed minutes of condolence after George Stewart's death: The Otago Provincial Council of the Farmers' Union, Tapanui Farmers Club, Otago Agricultural and Pastoral Society, Dunedin City Council, Heriot Presbyterian Church Committee, Lawrence Borough Council, Crookston Farmers' Union, Tuapeka County Council, Board of Governors of Otago Boys' and Girls' High Schools, Lawrence County Council Chambers, and the Patients' and Prisoners' Aid Society. Several women's organisations also acknowledged George Stewart's death, including the Crookston Branch of the Presbyterian Womens' Missionary Union, the Knox Church Patriotic Sewing Bee, the Society for the Protection of Women and Children, Dunedin branch, and the OSWPA.

131 Winter, Sites of Memory, Sites of Mourning, 94.

132 The Freemasons were represented in Tapanui by the Masonic Lodge Hercules, established 1880. The Loyal Tapanui Lodge of Oddfellows was established in 1869. There was a class dimension to fraternal societies. The more prosperous tended to become Freemasons whereas the Oddfellows' lodges were the preserve of the skilled workingclasses. See McAloon, No Idle Rich, 151-152. It is unusual that George Stewart, as a prominent middle-class man, did not join his local Masonic Lodge. The Tapanui Oddfellows Club exhibited a 'Roll of Honour' in its lodge-room during the war to provide a record of Lodge men who had enlisted. By February 1916, the names of 20 members were recorded on the Roll. 'Oddfellowship,' Tapanui Courier, 2 February 1916. See also 'Tapanui Lodge Roll of Honour,' URL: http:www.nzhistory.net/media/photo/tapanui-lodge-roll-honour-board (Ministry for Culture and Heritage), accessed 12 December 2011.
} 


\section{Conclusion}

The forms that homefront condolence took were shaped by a series of overlapping categories and communities: a geographic community which bore the imprints of prewar life and associational culture, wider circles of connection moulded by extended family and friendship networks, as well as a soldier's immediate contacts in the army. While previous scholars have emphasised the tendency of even homefront communities of condolence to situate the war dead within militarised narratives of heroic sacrifice, this was not the case in the condolence letters received by George Stewart's family. Those who remembered George Stewart's life highlighted his civilian accomplishments more often than his achievements in war. In expressing gratitude that George died peacefully and with his wife by his side, they voiced sentiments more closely in line with civilian ideals of bereavement than with the idealised death of the heroic soldier. Gender formed an important component of the forms that consolation, and later commemoration, took. A strong homosocial trend can be observed in condolence letters: individual letters writers were far more likely to address their letters to an individual of the same sex, while the genre of condolence letter-writing as a whole was dominated by women. The planning and construction of war memorials also reflected the strongly homosocial tendencies that structured the pre-war associational life of local communities such as Crookston. In other respects, expressions of condolence by men and women shared elements in common: both male and female writers drew upon Christian faith to console the bereaved relatives, although these references were more common in letters by women. Writers of both sexes voiced the importance of the ideals of duty and service, although men were more likely to do so. But as the next chapter will demonstrate, such ideals were not universal among all classes. Significant numbers of New Zealand families experienced the war as hardship rather than duty. 


\section{CHAPTER FIVE}

\section{'KEEPING THE HOMES GOING': FAMILIES AND THE OTAGO SOLDIERS' AND DEPENDANTS' WELFARE COMMITTEE. ${ }^{1}$}

On a crisp spring day in November 1916, Mary Downie Stewart descended from the Stewart family home of 'Ashentree', with its leafy vantage point overlooking much of Dunedin's city flats and surrounding hillside suburbs, to venture into the North Dunedin home of Mrs Hewitt. ${ }^{2}$ Mrs Hewitt shared the house with her six-year-old brother, whom she and her soldier husband had adopted. Mary's subsequent written report on Mrs Hewitt's financial circumstances detailed the changes in her situation since her husband had left for military camp. As she had waited for his military pay to commence, the costs of maintaining herself and her younger brother ate into their savings, while a recent operation rendered her temporarily unable to supplement the family income through her own paid work. As a cost-cutting measure, she had recently moved into her rented dwelling, but this move had been accompanied by its own expenses, as the house had no gas or facilities for laundry and she had been forced to purchase lamps and equip it with a tub. As well as listing the household's various items of income and expenditure, Mary Downie Stewart also commented upon the condition of the house and the standard of its keeping: 'tidy \& comfortable', and on Mrs Hewitt herself: 'a very nice woman'. On the basis of Mary's report and recommendations Mrs Hewitt was granted a temporary allowance of $f_{1} 1$ per week for two months and an ongoing allowance of 10 s per week by the Otago Soldiers' and Dependents' Welfare committee (OSDWC), upon whose behalf Mary was acting as 'lady visitor.'

\footnotetext{
1 This chapter title is taken from an Evening Post article on the subject of separation allowances. 'Keeping the Homes Going,' Evening Post, 27 September 1917, 6.

${ }^{2}$ In accordance with the conditions of my access to these restricted files, the names of individual welfare recipients cited in this chapter have been changed to disguise their identities.

3 World War I Case Files (hereafter OSDWC Casefiles), AG-113/040 to AG-113-155, Otago Provincial Patriotic Council Records, ARC-0514, HL.
} 
During the war, Mary Downie Stewart and her fellow welfare visitors stepped outside of their comfort zones and familiar social worlds and into the homes of some of Dunedin's poorest residents. This chapter mirrors Mary's journey as it moves out of the privileged social circles which have thus far formed the subject of this thesis, and into the vastly different social world inhabited by working-class families during the war. We have little choice but to view these encounters primarily through the eyes of Mary and her fellow visitors. Few Dunedin working-class families left behind a family archive equivalent to that of the Stewarts. However, some individuals wrote to the OSDWC to present their case for assistance, and the records of their correspondence provides a counterpoint to the perspectives of Mary and her OSDWC colleagues. ${ }^{4}$

Earlier chapters have documented the emotional damage experienced by the Stewart family as a result of the war. Mary Downie Stewart's welfare visiting work during the war brought her into contact with families who had suffered economically as well. This chapter charts the war's disruptive influence on family life and family economies through the evidence contained in the OSDWC's records. It thus uncovers aspects of the family story of the war upon which the Stewarts' archive falls silent. Worries over money rarely enter the Stewart family's letters; the family's comfortable financial circumstances buffered them from this aspect of the war's impact. ${ }^{5}$ The same cannot be said for families who relied upon the OSDWC for support during the war. Poverty was nothing new for the families of Dunedin's working-class suburbs. ${ }^{6}$ In some ways the plight of these families during the war simply rehearsed the familiar patterns and causes of impoverishment of the early decades of the twentieth century: such poverty affected women and children disproportionately, and stemmed from underlying causes such as widowhood, unemployment, old age, illness, disablement, neglect, and state policy. ${ }^{7}$ Yet the war added new stresses to those already struggling, while pushing

\footnotetext{
${ }_{4}^{4}$ The plight of the families of working-class soldiers was given considerable publicity by the labour movement in this period.

5 On his departure for war in January 1916, William instructed Mary not to 'cut down expenses at Ashentree \& just draw what money you need'. William to Mary, 8 January 1916, MS-0985-049/004, HL.

${ }^{6}$ Thanks to the collaborations of history staff and students at the University of Otago on the 25-year Caversham project, we now know more about the lives of the residents of Dunedin's southern suburbs from the late nineteenthto early twentieth centuries than any other New Zealand urban area. Annabel Cooper and Marian Horans' chapter on poverty in Sites of Gender has been particularly important in informing the present chapter. Annabel Cooper and Marian Horan, 'Down and Out on the Flat: The Gendering of Poverty,' in Sites of Gender, eds., Brookes, Cooper and Law, 190-225, 399-403.

7 While the 1890s and 1910s witnessed the introduction of significant welfare measures by the state, recent welfare historians have assessed this period's welfare provisions as positively miserly in comparison with the more comprehensive state benefits introduced later in the century. See Tennant, Paupers \& Providers; - , The Fabric of Welfare: Voluntary Organisations, Government and Welfare in New Zealand, 1840-2005 (Wellington: Bridget Williams Books, 2007).
} 
even some relatively prosperous families into desperate financial straits. Both married and single mens' departure for war could leave families bereft of their major breadwinner and the shortfalls between prewar income and state provisions for soldiers' dependants could be great. For many soldiers' families the heartbreak of losing a loved one during the war was compounded by worries over their ongoing ability to cover their expenses. As Marina Larsson has poignantly demonstrated in the Australian context, the costs of war-related illness, disability, and psychological damage were absorbed disproportionately by soldiers' families, despite government promises to compensate them generously for their sacrifices. ${ }^{8}$ Both the financial hardships and burdens of care undertaken by families constitute a further sense in which this conflict can be regarded as a 'family war', an experience which extended well beyond the front lines.

As Rollet has argued in the British context, the introduction of military service brought to the surface the tensions inherent in a wartime propaganda effort framed around the need for men to go away to war to protect an idealized home:

[T] he propaganda appeal was to protect the home from the depredations of the external enemy, but enlistment could destroy the home life that was theoretically being protected. Men could argue that the financial, emotional, and general damage to well-being... which would result from their conscription, utterly negated any theoretical defence of the 'home' by joining the colours... it is that tension which was frequently enacted in military tribunal hearings. ${ }^{9}$

The belief that military service represented the apex of masculine duty and male citizenship during the war received its single greatest qualification in the recognition of men's domestic responsibilities as breadwinners for their families. The war-time plight of many working-class families complicates the moral framework of service or selfishness which, earlier chapters have argued, formed the dominant perspective through which the Stewarts and their influential circles judged individual conduct during the war. By the 1890s, Erik Olssen argues, for the men of the skilled working classes, 'a job and a wage sufficient to support a family had become central to their identity as

\footnotetext{
${ }^{8}$ Larsson, Shattered Anzacs. While neither focuses on the experiences of families specifically, both Barry Gustafson's history of the Labour party and Libby Plumridge's MA thesis provide valuable historical context for this chapter's discussion of the working classes and the homefront during the war, particularly in relation to the impact of the rising cost of living. Gustafson, Labour's Path to Political Independence; Plumridge, 'Labour in Christchurch'.

${ }_{9}$ Rollet, 'The Home and Family Life,' 317-318.
} 
husbands, fathers and heads of household, or, as the census put it from 1901 onwards, 'Breadwinners'. ${ }^{10}$ During the war, some working-class men rejected the moral perspective that men who placed family responsibilities above nation or Empire committed an act of selfishness. Some men entered the army unwillingly after being called up in the ballot for military service; others volunteered but stressed the obligation that their service placed upon governments and patriotic societies to provide for the families they left behind. Soldiers' correspondence in patriotic society records demonstrates the lengths to which some men went to maintain domestic identities as husbands, fathers and sons, in spite of the distances of war. Yet, as the welfare casefiles also reveal, for some families the pressures and separations of the war proved insurmountable.

\section{Families and government policy}

The experiences of working-class families were shaped, in large measure, by government policy. Government expected all families to make sacrifices for what it viewed as the more pressing cause of the war effort, at the same time as it introduced policies which aimed to ameliorate the worst of the war's impact upon families. As Gwen Parsons has argued, governments were 'not keen for married men to volunteer, fearing the associated financial and social cost to the country' and it was only after the introduction of conscription that it was confirmed that 'a married man's duty to the state superseded that to his family - although that duty would not be required until all the single men had been balloted'. ${ }^{11}$ Families were central to the arguments that circulated both for and against conscription prior to its introduction in June 1916. The fear that the reluctance of some single men to enlist would force married men with families into the front lines was one of the most significant arguments raised in favour of introducing conscription. ${ }^{12}$ Equality of sacrifice - a key concept behind support for conscription was measured by the family unit. Entire families 'did their duty'; those who did not were 'family shirkers'. Speaking in December 1915, Timaru MP James Craigie criticised the voluntary system as not allowing for equality of sacrifice. The Otago Daily Times reported that: 'He cited the case of a widow who sent four sons to the war, while some other people did not send any sons. All people should be prepared to share in the sacrifice,

\footnotetext{
${ }^{10}$ Erik Olssen, 'Working Gender, Gendering Work: Occupational Change and Continuity in Southern Dunedin,' in Sites of Gender, eds., Brookes, Cooper and Law, 51; Olssen, Building the New World, 252.

${ }^{11}$ Parsons, 'Debating the War: The Discourses of War in the Christchurch Community,' 558-559.

12 Baker, King and Country Call, 52-53.
} 
and thus have equality. ${ }^{13}$ The plight of soldiers' families also formed a prominent part in the arguments of those who opposed conscription, and those who argued for the conscription of wealth in addition to manpower. For instance, some labour leaders argued that conscription was unnecessary and that volunteers would have come forward readily had the government put in place adequate provisions for their dependants' support. ${ }^{14}$ For 'Family Man', who wrote to the Otago Daily Times in October 1916, the need to raise funds to support soldiers' families formed a compelling argument for extending conscription to wealth: 'It would be a bitter reflection to us when in France, up to our knees in mud in the trenches, fighting for our country, that our wives and loved ones were fighting to keep the wolf from the door'. ${ }^{15}$

After its enactment by Parliament in June 1916, military conscription was managed in such a way that married men with families would be sheltered from compulsion until such time as the supplies of eligible single men had been exhausted. ${ }^{16}$ This objective was achieved by classing men into two divisions. Single men and those who had married after 1 May 1915 were placed in the First Division, to be called up first. ${ }^{17}$ Section 35 of the Military Service Act, the so-called 'family shirkers' clause, provided for the immediate conscription of eligible men in families with two or more eligible brothers who had not enlisted. ${ }^{18}$ Men who had married before 1 May 1915 fell into the Second Division, to be balloted only after all First Division men in the military district had been called up. Second Division men were further classed into categories which ensured that men with fewer children would go before those with large families. ${ }^{19}$ In the event, as Paul Baker notes, few Second Division conscripts ever reached the front. While Second Division men began to be conscripted in October 1917, they did not reach camp in New Zealand until April or May 1918, and the war ended soon after their arrival in England. ${ }^{20}$ Nevertheless, as this chapter's analysis of the OSDWC's casefiles illustrates, some married men with significant family responsibilities elected to

\footnotetext{
13 'The Voluntary System,' Otago Daily Times, 18 December 1915, 3.

14 Plumridge, 'Labour in Christchurch', 72. For the position of the Labour leadership on conscription see Gustafson, Labour's Path to Political Independence, chapter 10.

15 'Married Men and Conscription,' Otago Daily Times, 26 October 1916, 3.

16 Baker, King and Country Call, 89.

17 Ibid.

18 Ibid., 87.

19 Ibid.

${ }^{20}$ Lengthy delays were experienced in mobilising the Second Division. Many Second Division conscripts were successful in appealing their conscriptions, while Second Division conscripts were also rejected for medical reasons at high rates. Ibid., 147-151.
} 
enlist voluntarily, while many households were reliant on the support of single male volunteers or conscripts.

Competing domestic responsibilities rated highly among the reasons for individual applications to the Military Service Boards appointed to hear appeals against conscription. David Littlewood, who has studied the operations of the Wellington boards, found that most men who appealed their conscription under the second most popular category for appeal - 'undue hardship' (representing close to 47\% of appellants) - did so on the basis that their families needed their financial or physical support. ${ }^{21}$ As Littlewood's research suggests, the mainly middle-class Boards often sympathised with men with significant family responsibilities, and sometimes proved willing to grant them temporary or permanent exemption from conscription. Boards were also willing to show leniency towards men whose families the members judged to have already taken their fair share in the sacrifice. In granting the appeal of Peter William Jones, hairdresser of North East Valley, Dunedin, the Chairman of the Otago Military Service Board stated: 'The family had done very well, two brothers having been killed at the front, and another had gone, while appellant had tried to go'. ${ }^{22}$ Nevertheless, newspaper reports of the Board's proceedings suggest that their primary commitment was to the concepts of duty and equal sacrifice. As Littlewood has written, the boards shared the conviction that "'all had to put up with hardships and troubles in these times"” and tended to regard 'unwillingness to serve as a dereliction of duty'. ${ }^{23}$ Claude Alan Coombes, of Otago, who appealed his conscription on the basis that he was the sole support for his mother, younger brother and six sisters, was reminded by Otago board members that the national need was paramount: 'they had to remember that the war was still going on, and the country could not wait'. ${ }^{24}$

At the same time, governments introduced financial measures aimed at buffering the impact of war on soldiers' families. However, even after such measures were taken

\footnotetext{
${ }^{21}$ Those claiming 'Undue Hardship' represented around 47 per cent of total appellants. The other categories for appeal were 'Public Interest', 'Not a Reservist', 'Wrongly Classed', or 'Objections'. Despite the level of historial attention they have received, those voicing concientious objections represented only 4 percent of appellants. See Littlewood, “Should He Serve?," 64-66. Rollet's study of the Middlesex Appeal Tribunal, covering outer London, found that 30 percent of appeals were on domestic grounds alone, while a further 10 percent were on domestic and other grounds. Rollet, 'The Home and Family Life,' 319.

22 'Military Service Boards Sitting at Dunedin,' Otago Daily Times, 10 February 1917, 10.

${ }^{23}$ Littlewood, "'Should He Serve?," 45.

${ }^{24}$ The Court heard that Coombes had six brothers. One brother had been killed at the front, three were married and one was ten-year-old child. His appeal was dismissed on the grounds that his other brothers should support his mother and siblings. 'Military Service Board,' Grey River Argus, 17 January 1917, 3.
} 
into account, joining the military represented a financial sacrifice for all but the poorest of wage-earners. The allotment system, introduced late in 1914, made provision for soldiers to allocate a portion of their military pay to their dependants. ${ }^{25}$ While soldiers with dependants received higher pay than those without, pay rates for soldiers with dependants were still well beneath even the lowest civilian wages. In 1916, for instance, a private with a dependant wife or mother received military pay of $£ 899 \mathrm{~s}$ per year. This compared to the lowest annual arbitration award rate in 1916 of $£ 1322 \mathrm{~s}^{26}$ In June 1915, the Defence Department introduced separation and children's allowances to be paid directly to the wives or dependent widowed mothers of soldiers at the rate of $1 \mathrm{~s}$ per day, or $£ 155 \mathrm{~s}$ per year, and at the rate of $6 \mathrm{~d}$ per diem for each child. ${ }^{27}$ But the government kept the rates of allowances to soldiers' dependants deliberately low as it feared increasing them might create an incentive to married men to enlist, thus increasing the financial burden on the state. Questioned in 1916 over the inadequacy of the allowances, Minister of Defence James Allen responded that 'a higher separation allowance would bring about a state of things which the department did not want to create. It would encourage married men with children to enlist. What they wanted was to get the single men first'. ${ }^{28}$ During 1915 the government also introduced pensions for the dependants of deceased or disabled soldiers. ${ }^{29}$ From January 1917, families were also eligible to apply to the Financial Assistance Board for help in meeting ongoing financial commitments such as insurance payments or mortgages. ${ }^{30}$

By the rates current in April 1917, if a private alloted his wife the governmentrecommended rate of $4 \mathrm{~s}$ per diem ( $£ 1$ 8s per week), her total weekly income, once a government separation of $7 \mathrm{~s}$ per week was added, would equal $f_{1} 15 \mathrm{~s} .{ }^{31}$ If she had one or more children, she could expect to receive an additional $5 \mathrm{~s} 3 \mathrm{~d}$ from the government for each child, making the minimum income for a soldier's wife with one child $f^{2} 2 \mathrm{~s}$,

${ }^{25}$ Melanie Nolan, 'Keeping New Zealand's Home Fires Burning: Gender, Welfare and the First World War,' in New Zealand's Great War, eds., Crawford and McGibbon, 502.

${ }^{26}$ Baker, King and Country Call, 37.

27 'Separation Allowance,' Evening Post, 10 June 1915, 6; Annual Report of the Defence Forces of New Zealand, AJHR, 1920, H-19, 3; Baker, King and Country, 57.

28 'The Estimates,' Otago Daily Times, 1 July 1916, 8.

${ }^{29}$ By 1917 rates, the widow (or dependant mother) of a deceased soldier receiving the minimum pension rate of a private would be paid $f_{1} 10$ s per week if she had no children, $f^{2}$ if she had children, and an additional 10s per week for each child. In the event of his disablement, a soldier receiving a pension in 1917 at the private's rate would have been paid $£^{2}$ per week, with an additional $£ 1$ if he was married, and 10s for every child. 'War Pensions,' New Zealand Official Year Book, 1918, URL: http://www3.stats.govt.nz/New_Zealand_Official_Yearbooks/1918/NZOYB_1918. html, accessed 10 March 2014.

${ }^{30}$ Baker, King and Country Call, 118.

31 A 1916 government guide to allotments suggested that soldiers supporting wives allot 4 shillings per day ( 1 $^{1} 8$ s per week) to their wives' support. For soldiers supporting mothers the recommended rate was 3 shillings per day ( $£_{1} 1 \mathrm{~s}$ per week). Nolan, Breadwinning, 97. 
with two children $£ 25 \mathrm{~s} 6 \mathrm{~d}$, and so on. If disabled, the same man could expect to receive a military pension of $£, 52$ per year. If killed, his widow would receive $f, 98$ per annum. ${ }^{32}$ Increased rates for separation and children's allowances introduced from January 1918, in advance of the entry of the first Second Division conscripts into camp, meant that the same soldier's wife would have received $f^{2} 9 \mathrm{~s}$ per week from the combined income of her husband's allotments and the government's separation allowance, plus an extra $7 \mathrm{~s}$ per week per child. ${ }^{33}$ Countering the benefits of these increased allowances was the rising cost of living. Already an issue before the war, the increasing cost of living had been the subject of a Royal Commission in $1912 .{ }^{34}$ Upon the outbreak of war, the price of essentials such as groceries, coal and housing continued to rise - with the Government Statistician recording a 39 per cent increase in grocery prices alone over the war years. ${ }^{35}$ Thus, it is probable that the benefits to families of increased allowance rates were largely offset by wartime rises in the cost of living.

\section{Otago Soldiers' and Dependents' Welfare Committee}

The shortfall between civilian wage rates and the combined incomes received by soldiers' families from military pay and government allowances created a gap that patriotic societies sought to fill with their voluntary efforts. In Otago, an 'Employment and Relief Committee' (otherwise known as the Otago Soldiers' and Dependents' Welfare Committee), was established under the auspices of the Otago Patriotic and General Welfare Association in 1914. It was charged with assessing applications for financial relief received from soldiers or their dependents, and in dispensing funds to eligible applicants. ${ }^{36}$ While the Committee transacted much of its business from its Cumberland Street offices in central Dunedin, it also employed a series of voluntary visitors to call upon soldiers' family members in their own homes. In October 1915, Mary Downie Stewart was appointed as one such 'lady visitor' on behalf of the OSDWC.

\footnotetext{
32 In 1916, the rate was from $£_{8} 89$ per annum for a soldier's widow. Annual Report of the Pensions Department for 1916 and 1917, AJHR, 1917, H-18, 2.

33 'Soldiers' Pay and Allowances,' Otago Daily Times, 17 October 1917, 5.

${ }^{34}$ Gustafson, Labour's Path to Political Independence, 96-97.

${ }^{35}$ Figures from the New Zealand Official Year Book show that grocery prices rose 39.35 per cent over the war years, while rents rose significantly in Wellington, Christchurch and Dunedin over the war years. The price of coal rose throughout New Zealand from 1915. New Zealand Official Year Book, 1919, Section XXX: Prices and Wages, URL: http://www3.stats.govt.nz/New_Zealand_Official_Yearbooks/1919/NZOYB_1919.html, accessed 10 March 2014. On the cost of living see also Gustafson, Labour's Path to Political Independence, chapter 9.

${ }^{36}$ Mary remained active as a visitor from 1915 until March 1917, when she left Dunedin to accompany her brother William to Sydney, and later to Wellington on his return to Parliament. While this chapter's focus is on the assistance the OSDWC provided to soldiers' families from 1914 to 1919, the OSDWC remained active in supporting soldiers and their dependants in the interwar years, and was still receiving applications for assistance as late as the 1980s.
} 
Mary Downie Stewart was one of four welfare visitors who oversaw the Committee's visiting work during the war. The OSDWC drew upon pre-war precedents in its use of home visitors to assess potential welfare applicants. ${ }^{37}$ While working for the OSDWC during the war was Mary Downie Stewart's first experience of home visiting, two of her visiting colleagues were seasoned home visitors. The Reverend Francis Cumming, the sole male visitor, had previously worked as a chaplain and a probation officer - a role that involved visiting discharged prisoners in their homes. In addition, Cumming had served on the Otago Charitable Aid Board before the war. ${ }^{38}$ The only working-class visitor, trade unionist Jane Runciman, had previously served as 'lady district deputy' for the Ruth Rebekah Lodge, which advocated for deserted wives, and had joined the Society for the Protection of Women and Children in $1914 .{ }^{39}$ Little is known of the background of Annie Park, who acted as visitor from 1915 until 1919, although her co-membership of the OSWPA committee is suggestive of an upper-class background.

After visiting a soldiers' home, visitors completed a report upon the family's circumstances. ${ }^{40}$ The OSDWC's all-male committee reserved for itself the ultimate power to decide upon the level of assistance, if any, it was willing to allocate to each particular applicant. Nevertheless, because their visits were frequently the only form of contact the committee had with applicant families, the visitors' views were likely to have been influential in informing its decisions. The visitors' reports give little indication of what took place in these interactions between working-class families and primarily middle-class visitors. Writing of the work of the middle-class 'lady visitors' charged with visiting applicants for relief to Canadian patriotic societies, Robert Rutherdale writes that the visitors 'supervised how poorer soldiers' wives budgeted their overall monthly incomes' and provided 'dispensing advice containing its expenditure'. ${ }^{41}$ The surviving records of the OSDWC provide no evidence on whether its visitors sought to 'educate'

\footnotetext{
${ }^{37}$ Charitable organisations involved in work with women and children had used female visitors to visit poor families since the late nineteenth century, drawing on an established English tradition of charitable visiting of the poor. See Tennant, Paupers \& Providers, 15-16, 70-73. For upper-class female reformers in the US context see Linda Gordon, Heroes of their Own Lives: The Politics and History of Family Violence (New York: Penguin, 1988), chapter 2.

38 Gordon Parry, 'Cumming, Francis George - Biography,' DNZB, updated 30-Oct-12, URL: http://www.TeAra.govt.nz/en/biographies/3c43/cumming-francis-george, accessed 20 May 2013. Cumming retired as OSDWC visitor in September 1916 to focus full-time on his Patients' and Prisoners' Aid Society work.

${ }^{39}$ Nolan, 'Runciman, Jane Elizabeth - Biography.'

${ }^{40}$ For other studies drawing upon welfare casefiles see Gordon, Heroes of their Own Lives; Labrum, 'Family Needs and Family Desires'; Mark Peel, 'Charity, Casework and the Dramas of Class in Melbourne, 1920-1940: "Feeling Your Position,"' History Australia 2, no. 3 (2005): 83.1-83.15.

${ }^{41}$ Rutherdale, Hometown Horizons, 111.
} 
the working-class women they visited, while Mary Downie Stewart's letters are uncharacteristically silent on this aspect of her war work.

Little evidence exists to support Melanie Nolan's contention that the OSDWC's three female visitors underwent a radicalisation and awakening to social and economic injustices as a result of their wartime experiences. ${ }^{42}$ Jane Runciman, the only one who fits Nolan's description of the three women as 'labour activists', had been exposed to the lives of the poor well before the war. Mary's tendency to attribute the circumstances of the families she encountered to individual failings or accidents of fate rather than deeper social inequalities underwent no observable shift during the war. ${ }^{43}$ In 1919, Mary publicly voiced her belief that that the severity of the recent influenza pandemic was attributable to poor housekeeping. ${ }^{44}$ While not unsympathetic to the plight of women neglected by husbands or families forced into poverty through illness or disability, the OSDWC's visitors - with the possible exception of Runciman - reserved their greatest level of compassion for those families whose circumstances appeared entirely attributable to their 'war sacrifice'.

After receiving a family's application for assistance and enquiring into their case, the OSDWC typically dispersed its financial and material aid in the form of weekly allowances, set by a schedule of relief determined by the Committee. It also awarded small grants to pay for groceries or coal or to meet financial commitments such as insurance payments. ${ }^{45}$ Thus, it mirrored a pattern adopted by earlier charitable relief authorities such as the Otago Benevolent Institution. In doing so, it imposed upon working-class aid recipients what Annabel Cooper and Marian Horan describe as a 'middle-class pattern of masculine "giving". ${ }^{46}$ In middle-class homes it was customary for husbands to manage the household funds and hand their wives an allowance for housekeeping purposes. This contrasted with the practice in working-class households, whereby it was usual for the husband to hand over his pay packet for his wife to

\footnotetext{
42 Nolan, 'Keeping New Zealand's Home Fires Burning,’ 511.

${ }^{43}$ This was a common perspective among English female philanthropists of the late nineteenth and early twentieth centuries. See Lewis, Women and Social Action, 13. See also Prochaska, Women and Philanthropy, 219-20.

${ }_{44}$ Mary Downie Stewart, speech to the Dunedin branch of the Mother's Union, c. 1919, MS-0985-053/007, HL.

45 As of November 1916, the OSDWC's schedule for relief specified that a soldier's wife with one child would receive receive $£ 1$ per week for the first month after her husband's departure for camp, 12 s per week for the second month, and $5 \mathrm{~s}$ per week thereafter, with these rates increasing for each additional child. No schedule existed for soldiers' mothers or dependants, but weekly payments to such applicants mostly fell beneath 12 s per week. OSDWC Minutes, 23 November 1916, AG-113/176, HL.

${ }^{46}$ Cooper and Horan, 'Down and Out on the Flat,' 221.
} 
manage, after first removing his own 'pocket money'. ${ }^{47}$ The OSDWC's pattern of distributing funds thereby removed from working-class women an aspect of household decision-making over which they traditionally exercised a degree of autonomy. ${ }^{48} \mathrm{By}$ contrast, in the case of returned soldiers, the OSDWC was far more willing to give assistance in the form of large grants or loans to start business or equip themselves with work tools or clothing or, if engaged or newly married, to fund house deposits or the purchase of furniture. ${ }^{49}$ Thus, while the OSDWC envisaged its role in relation to returned soldiers as to equip them for a future as independent breadwinners and providers, it saw its role in relation to soldiers' dependants as a temporary measure 'for the duration' rather than a more long-lasting arrangement.

\section{OSDWC archive and methodology}

The surviving First World War records of the OSDWC consist of over 11,000 casefiles dating from 1914 to the 1980 s, as well as minute books and correspondence files. ${ }^{50}$ This chapter's analysis of the casefiles draws upon a sampling of files from the years 1914 to 1919. The following sampling method was adopted: all files containing applications from soldiers' family members (as opposed to applications made directly by soldiers) were selected out of a sample of just over 20 percent of the total casefiles. ${ }^{51}$ This resulted in a total of 202 applications from soldiers' families, upon which the quantitative aspects of this chapter's analysis are based. In her study, Nolan identified a total of 919 applications made by soldiers' families over the war years, suggesting that this chapter's sample represents around 20 per cent of the total applications made by soldiers' families to the OSWPA over the years 1914 to $1919 .^{52}$ The casefiles contained a diverse range of information relating to family life during the war, including an

\footnotetext{
${ }^{47}$ For the practice in working-class homes see Olssen, 'Working Gender, Gendering Work,' 61. The middle-class custom is seen in a letter Rachel Stewart wrote upon the eve of her marriage to George Armitage in 1903. In it, she informed him that, upon their marriage, she intended to pay all her money into his account for him to manage and pay her an allowance out of. Rachel to George Armitage, 26 February 1903, MB-312-18/141, MBL.

48 Cooper and Horan, 'Down and Out on the Flat,' 221.

${ }^{49}$ For example, Thomas MacNab, discharged from the army in December 1918 and employed as a labourer at the Hillside Workshops was granted a $£ 25$ interest free loan towards the purchase of a house he was buying through the Land Board. OSDWC Casefiles, AG-113/070, HL.

50 Patriotic Societies delineated their responsibilities by the soldiers' place of residence for 6 months prior to his enlistment. However, men tended to apply to the closet Patriotic society to their current residence, who would then correspond with the responsible Patriotic society and provide assistance upon their behalf. Thus Otago casefiles also contain the files of men who enlisted in other districts but resided in Otago after the war.

51 The sampling method used in this analysis is as follows: Every fifth box of files (each containing between 50 and 120 casefiles) was selected. Out of these 2281 casefiles, all files containing applications from soldiers' families or dependants were selected, resulting in the sample of 202 case files. It is upon this sample that this chapter's analysis of family circumstances is based. The presence of one or both of two form types: 'Application from a Soldiers' Dependant' or 'Visitor's Report', indicates that the application for assistance was received from the family of a soldier.

52 Nolan, Breadwinning, 100.
} 
applicant's address, living arrangements, occupation, and income, as well as the visitor's comments and any record of action taken by the Committee or visitor. These form the bulk of the evidence for the next section's investigation of the family economy during the war. ${ }^{53}$

\section{The First World War and the family economy}

Disaggregating applicants for OSDWC relief by family type suggests that families headed by soldiers' wives were the most vulnerable households during the war. Out of 202 applications in this chapter's sample, 125 were from soldiers' wives. The high representation of soldiers' wives among applicants to the OSDWC contrasts with the low numbers of married men in the NZEF overall. While more than 90 per cent of the NZEF were single upon enlistment, 61.9 per cent of applications to the OSDWC came from soldiers' wives, as seen in chart 5.1 below. ${ }^{54}$ Most households led by a soldier's wife contained at least one dependant child. ${ }^{55}$ Among 125 soldiers' wives, 27 had no children living at home, 48 had 1 child, 25 had 2 children, 14 had 3 children, and 10 had 4 or more children. ${ }^{56}$ The next most common type of applicant by household type was that of the unmarried soldier, headed by a parent (usually a mother) or parents, frequently with one or more of their resident children, and sometimes additional family members cohabiting in the same household, such as grandparents, or boarders. Soldiers' mothers headed the household in 33.2 per cent of applications. Out of the households headed by soldiers' mothers, 14 had one of the soldiers' other siblings resident at home, 8 had two siblings resident at home while 13 had three or more siblings resident at home. The remaining applicant types: soldiers' fathers, children or siblings, made up less

\footnotetext{
53 'Applications from Dependant' forms recorded an applicant's address, their soldier husband or son's occupation and wages, household income details, amount of allotment, numbers of dependants, significant items of household expenditure such as rent or insurance, as well as a space for the comments of the Committees' visitor or representative. In addition, casefiles recorded the Committee's decision on whether to grant assistance. Visitor's Reports included descriptions of the dwelling, its occupants and condition and the visitors 'remarks' on a particular case. For the insights the OSDWC casefiles provide into the family economy see also Nolan, 'Keeping New Zealand's Homefires Burning,' 507-515.

${ }^{54}$ It is difficult to accurately estimate the percentage of married men among the NZEF as a whole, as many men married in between enlisting and their departure for war, or while overseas. 5 per cent of the 8000 -strong Main Body declared themselves to be single upon enlistment, but numbers of married men rose slightly for subsequent reinforcements. 6.9 per cent of recruits up to the end of 1915 declared themselves to be married, while 7.6 per cent of volunteers up to the introduction of conscription in June 1916 were married. Baker, King and Country Call, 57.

55 OSDWC policy was to assist only wives with dependent children, as it considered that the combined income from their husband's allotments and the separation allowance should be sufficient to meet their needs, although it did make exceptions.

56 This excluded grown-up children living away from home, but included grown-up children living at home, regardless of whether they contributed to the family income or not. If the wife was recorded as being pregnant, this was counted as a child for the purposes of this analysis.
} 
than 5 per cent of the total applications combined. ${ }^{57}$ This distribution of applicants by family type is in line with the Committee's own figures. In a May 1917 report, for instance, it stated that it was assisting a total of 494 soldiers' dependants, including 303 wives (61 percent), 172 mothers (35 percent), and 19 applicants in other categories (4 percent). ${ }^{58}$

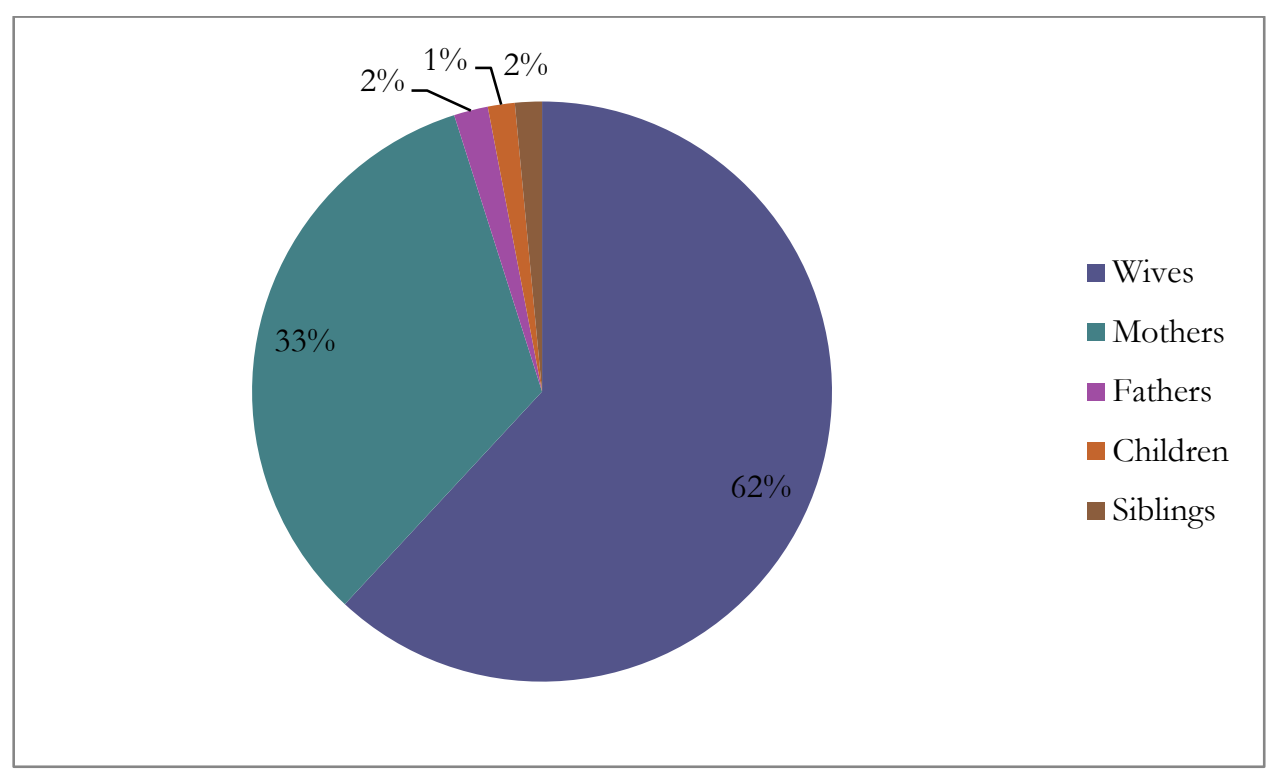

Figure 5.1: Applicants for OSDWC relief by relationship to soldier

The predominance of soldiers' wives among applicants for assistance can be explained through the gap in income between families' combined income from military pay and government allowances, and civilian wage rates. A typical example in the casefiles was that of Mrs Martha Webb. Martha and James Webb had married in 1916, and at the time James Webb went in to camp in April 1917 the couple had a 2-week-old baby. Her husband allotted the standard rate of $£ 18$ per week from his military pay. With the weekly separation allowance of $7 \mathrm{~s}$, and an additional $5 \mathrm{~s} 3 \mathrm{~d}$ for the child, her income during her husband's absence totalled $f^{2} 0$ s $3 \mathrm{~d}$, an amount significantly lower than her husband's pre-departure income as a jeweller of $f 35$ s per week. When one of the Committee's visitors visited Mrs Webb at her home in April 1917, she informed them that her rent of $f_{1}$ per week was 'too much' under her new income and she was 'trying

\footnotetext{
57 There are several possible reasons for the low representation of fathers. Fathers may have been more reluctant to approach the OSDWC for assistance as they may have regarded doing so as a shameful admission of their own failure as breadwinners, or they may have seen the household finances as their wife's preserve. The most probable explanation, however, is that the families' descent into poverty had been precipitated by the death or absence of the father.

58 OSDWC Minutes, 10 May 1917, AG-113/176, HL. This conclusion is also supported by Nolan's analysis of the OSDWC's casefiles, which suggests that soldiers' wives with children represented the most common applicant type, followed by soldiers' mothers. Nolan, Breadwinning, 100.
} 
to get some one to stay with her, or else someone to share house'. ${ }^{59}$ The OSDWC commenced payment of a weekly allowance to this woman from April 1917. By October 1917 she was also receiving 10s per week from the assistance Financial Assistance Board to cover life insurance payments and an outstanding loan of $f^{37}$ her husband had borrowed from his employer prior to his enlistment. The Committee found it necessary to pay this woman a weekly allowance from April 1917 until January $1918 . .^{60}$

It was not only the households of soldiers' wives and children who were adversely impacted by the departure of male family members overseas. The OSDWC casefiles provide insights into the far-reaching nature of the family economy in the early twentieth century, and the extent to which it diverged from the normative model of a sole male breadwinner supporting his dependent family members. While the vast majority of NZEF recruits were young, single and childless, many were still important providers for other family members such as parents and siblings. Typical patterns of residence in early twentieth century New Zealand meant that, unless called away by work or study, unmarried daughters or sons lived with their parents until such time as they married and set up their own households. The expectation that single adult children earning wages would contribute to their parents' support, even if living away from home, was high, although it diminished once children married and had families of their own to maintain. ${ }^{61}$ Wages added to the family income in this way in many cases supported not only aged parents, but siblings living in the household, including daughters kept at home to help with housework or care for other family members. The proceedings of the Otago Military Service Boards revealed similar arrangements. At one Dunedin sitting in August 1918, for instance, the Otago board heard the cases of Ernest McBride, a plumber and William Mills, telegraphist. McBride supported his mother, sister, and his invalid brother, who was 'absolutely unable to do anything'. Mills was the sole support for his household: consisting of an invalid brother, his mother and his sister who had a child. The Board reserved its judgement in both cases pending further investigation of each family's circumstances by the OSDWC's visitor Reverend Cumming. ${ }^{62}$

\footnotetext{
59 OSDWC casefiles, AG-113/050, HL.

${ }^{60}$ OSDWC casefiles, AG-113/050, HL

${ }^{61}$ Cooper and Horan, 'Down and Out on the Flat,' 202.

62 'Military Service Board,' Otago Daily Times, 7 August 1918, 2.
} 
In some households headed by soldiers' mothers, soldier sons had been the mainstay of the family income before the war. The departure of sons for war could impose considerable hardship upon such families. Annie Lawrence was a soldier's mother living in South Dunedin. Her son Frederick Ropata Lawrence, a painter, had lived at home with his mother before he was conscripted and left for camp in February 1917. Until then he had given 'all his money to Mother never less than a clear $f_{10}$ per month' out of his weekly salary of $f^{2} 17 \mathrm{~s} 6 \mathrm{~d} .{ }^{63}$ Clive Buchanan, one of two brothers who went to the front, was his mother's 'main support' before the war and had 'kept the house going since he was 16 years of age'. Clive was killed at Gallipoli in June 1915; the Committee agreed to pay his mother an allowance until her military pension arrived. ${ }^{64}$ Even some married men with their own families to keep were important contributors to their mother's support. When Herbert MacCallum went into camp in April 1918 his mother, a widow, applied for a Patriotic Society allowance as although her son was married 'he had always helped his mother'. ${ }^{65}$

Not all sons appear to have felt the same pressure of filial duty. Jane Runciman visited Mrs Read, a soldier's mother, in May 1918. Her son, employed at the dairy factory, had lived with her before the war, and had contributed $£^{2} 5 \mathrm{~s}$ out of his wages of $f^{2}$ 10s per week to the support of her household, whose occupants included Mrs Read's father 'an old man \& very trying', and Mrs Read's grandson, whom she had supported since his mother's death. When Runciman visited the household in May 1918 Mrs Read informed her that her son had 'sent her very little' since going into camp, and her family was six weeks in arrears on rent. In other cases, soldiers' parents underwent considerable sacrifices to avoid spending their son's allotment in order to have money for them on their return. ${ }^{66}$ Mrs Jane Smith, a 75 year old widow who the OSDWC supported with a weekly allowance between November 1917 and June 1919, was allotted 4s per day by her soldier son, Thomas Smith, but told the OSDWC's visitor that she was reluctant to use it 'so as to have something for him on his return home'. ${ }^{67}$ Annie Park visited Mrs Jane Langton, a widow with ten children, in her Caversham home in June 1916. Although a 'complete invalid' Jane Langton was reluctant to use her soldier sons' allotments. Park explained that: 'the mother's desire to save so much weekly from

\footnotetext{
63 OSDWC casefiles, AG-113/055, HL. 64 OSDWC casefiles, AG-113/085, HL. 65 OSDWC casefiles, AG-113/040, HL. ${ }^{66}$ OSDWC casefiles, AG-113/005, HL. ${ }^{67}$ OSDWC casefiles, AG-113/100, HL.
} 
her sons' allotment, springs from her experience of invalidism, and dread of her boys returning disabled'. ${ }^{68}$

For families reliant on the financial support of soldier sons, the grief of losing a son in wartime was compounded by the financial difficulties which attended such losses. ${ }^{69}$ When the case of Elizabeth Watts, a widow, first came under the Committee's notice in February 1916, her soldier son, who had been her main support before the war, had been reported wounded, believed killed. Mrs Watts' heavily mortgaged house required major drainage work which she was paying off in quarterly instalments. Also resident in the family home were her invalid daughter, earning $15 \mathrm{~s}$ per week, and a younger son on casual wages of $7 \mathrm{~s} 6 \mathrm{~d}$ per week. When a member of the OSDWC visited the house in March 1916 they 'found the woman not only in great sorrow on account of the loss of her son, but very hard-pressed to meet the payments' ${ }^{70}$ When Mrs Arnold, a soldier's mother whom the OSDWC assisted during the war, visited its offices in October 1918, one of the Committees' representatives described her as 'very ill' from the 'shock of her son's death' in May of the same year. Her son, who left with the Main Body in 1914, had given her $f_{100}$ to start up a grocery and dress-making business, but the business failed and she was forced to sell and move from her home into rented rooms. By May 1919 she was staying with a friend or relative in Fairlie, barely managing to subsist on a war pension of 16s per week and the OSDWC's weekly allowance of 10s: 'after paying Rent and Coal etc, there is nothing left. ${ }^{71}$

Even relatively prosperous families could be left struggling when multiple sons enlisted. Annie Park visited the Forrest family in May 1917. Four sons out of this family of ten children enlisted for military service, and one of these, Ernest, was killed at Gallipoli. The family's business as building contractors had prospered before the war, but due to the father's illness, relied heavily upon the labour of his sons. When Annie Park visited Mrs Forrest in May 1917 she found the family in 'bad circumstances', in arrears on mortgage payments and in danger of losing their Roslyn home. They owed f30 to the grocer 'for which he presses' and Mrs Forrest had sold her piano and sewing machine to make ends meet. Park stated in the Forrests' case: 'They have had 10

68 The Society agreed to pay this family's rent for three months. OSDWC casefiles, AG-113/055, HL.

${ }^{69}$ For the financial impact of soldiers' deaths on mothers in the Australian context, see Damousi, The Labour of Loss, 38-41.

70 The OSDWC granted this woman an allowance from March 1916 to August 1918. OSDWC casefiles, AG-

113/065, HL.

71 OSDWC casefiles, AG-113/055, HL. 
children \& their present strait is due entirely to war sacrifices'. ${ }^{72}$ By the time Annie Park visited again in March 1918, a fourth son, Clarence had also enlisted, while a daughter, Beatrice, 20 years old, was forced to stay at home to help her mother in the house. This family's willingness to place their war duty before their financial security, in spite of the terrible costs, appears to have touched the OSWDC's visitors deeply. Perhaps Park saw her own perspective on the war as sacrifice reflected in this family's plight. She wrote: 'The straitened means of this family are due entirely to the war, which has caused a loss of $£ 8$ weekly. Their obligations are heavy' ${ }^{73}$

The Forrests' predicament could be explained almost entirely by the war. In the case of other families, the war simply added a further strain to households already struggling to cope on already low or precarious incomes. Such vulnerable families were likely to see their situation worsen during the war. As studies of poverty from this period confirm, households headed by widows or which lacked a stable male breadwinner were singularly predisposed to poverty in this period. Writing of Dunedin's poor before the war, Cooper and Horan identify the absence of a regular male wage as 'the most critical element in defining poverty in this society. ${ }^{74}$ This conclusion is also confirmed by a closer inspection of the circumstances of soldiers' parents in the casefiles.

The majority of applications from soldiers' mothers to the OSDWC came from households in which the male breadwinner (represented here by the husband/father) contributed little or nothing to the household income. Out of the 63 applications from soldiers' mothers from which their husband's whereabouts could be ascertained, 20 were widows, 25 husbands were absent from the household without explanation, and four were separated from their wives and not contributing to their support. Illness, disability or old age explained seven husbands' inability to earn an income, and two more were inmates of institutions (a prison and an asylum). Only four fathers were both resident in the home and contributing towards its support. Of these four, it is notable that one was denied OSDWC relief on the grounds that the father's wages were deemed sufficient to meet the family's needs, while the remaining three earned only low wages

\footnotetext{
72 OSDWC casefiles, AG-113/105, HL.

73 This family's troubles continued after the war. Another son, Albert, returned to New Zealand in June 1919, after having had his right leg amputated at the thigh. An obituary notice recording his death followed in 1927. OSDWC casefiles, AG-113/105, HL.

${ }^{74}$ Cooper and Horan, 'Down and Out on the Flat,' 216.
} 
due to advanced age or incapacity. A few examples will suffice to illustrate the precarious financial circumstances in which such households existed. Mary Downie Stewart attributed the financial plight of Mrs MacFarlane, a soldiers' mother with dependent children, to 'the husband's illness for 10 years before his death 3 years ago [which] has handicapped the family'. ${ }^{75}$ Mrs Edwina Johnston, a soldier's mother whom Mary visited in July 1916, explained that her 'husband has been paralised [sic] for 16 years', when her eldest child was 6 years old ' $\&$ she has had to bring up her children'. The departure of her son, the household's main support, only exacerbated this family's difficulties. $^{76}$

\section{Mobility}

Aside from applying to the patriotic society for financial assistance, wartime families readjusted their lives to minimise spending or supplement their incomes in a variety of ways. Shifting residence was a common strategy adopted by working-class families in response to the hardships of war. Out of the 202 casefiles in the sample, sufficient information exists to trace the wartime movements of 175 families. Of these, 64 applicant families, or 36.6 per cent, shifted residence at least once between 1914 and 1919. High local mobility rates were characteristic in poorer communities at this time, as Brian Heenan and Sarah Johnsen have found for Dunedin's Caversham. ${ }^{77}$ But the mass mobilisation of soldiers overseas created an additional impetus for families' mobility. Such movements further attest to the unequal burden of the sacrifice war placed on working-class families. Unlike some poorer families, the Stewarts were never forced to choose between 'doing their duty' and giving up their family home. ${ }^{78}$ By contrast, the departure of soldier relatives forced many working-class families to move out of their existing accommodation and into the homes of family members or into cheaper housing in less desirable neighbourhoods.

The movements of applicant families reflected in the casefiles were of far smaller scales than those of the upper-class women whose mobility was the subject of

\footnotetext{
75 OSDWC casefiles, AG-113/090, HL.

${ }^{76}$ OSDWC casefiles, AG-113/125, HL.

${ }_{77}$ Brian Hennan and Sarah Johnsen found that, in Caversham between the 1890s and 1940s, 'roughly 65 to 70 per cent of all adults there at the start of any decade would be gone by its end'. These figures included deaths (accounting for 10 per cent of absences in 1902-1911, and 6 per cent of absences in 1911-1922). Brian Heenan and Sara Johnsen, 'To and From, There and Back: Gender in Spacial Mobility,' in Sites of Gender, eds. Brookes, Cooper and Law, 230. 78 The opposite was the case in Paris, where the outbreak of war saw a mass exodus of the Parisian middle classes out of Paris to the provinces. See Susanna Magri, 'Housing,' in Capital Cities at War: Paris, London, Berlin, 1914-1919, eds. Jay Winter and Jean-Louis Robert, rev. ed. (Cambridge: Cambridge University Press, 1999), 382.
} 
chapter two. Thirty five applicants moved between Dunedin addresses during the war years, 16 moved from another city or province outside Otago, while 10 applicants moved within the Otago region, typically from rural Otago into Dunedin city. Only two moved overseas during the war. Of these, one travelled to Australia and the other, Mrs Rachael Glover of Caversham, travelled to England after her officer husband was hospitalised there. Mrs Glover's income levels marked her out as exceptional among cases assisted by the OSDWC, and she was quickly struck off the committee's once they discovered her travel plans. ${ }^{79}$

Out of forty nine applicants who gave explanations for their moves, shifting to live with or in closer proximity to family formed the most common reason: providing evidence of the importance of extended kinship networks as a source of support for working-class families. ${ }^{80}$ Twenty seven individuals cited family reasons as the cause of their move: with 17 going to live with parents or parents-in-law (mostly mothers), six moving to live with or near a sister or sister-in-law, while a further four moved into the homes of a brother, son-in-law, daughter and unspecified relation, respectively. ${ }^{81}$ Family support was particularly important in the case of women with young children. A typical case was that of Mrs Abel. Her husband, Walter Abel, was the postmaster in a small rural settlement in Southland and went into camp early in 1917. When Mrs Abel's case was brought before the OSDWC in June of that year, a committee member noted that Walter Abel had 'been compelled to shift his wife child \& furniture to Dunedin so that his wife might be near his people'. ${ }^{82}$ After her husband enlisted, Mrs Winnie Cookson moved to live with her mother in Warrington, north of Dunedin. In a letter to the MP the Hon George W. Russell she wrote: 'I am living there with my widowed mother, whose only son is on active service, and we find it hard to keep going without the extra expense, as my mother gets no separate allowance and we live in a rented place, and the rent has always to be kept up'. ${ }^{83}$ While providing important support for families in wartime, such moves may have contributed to overcrowding in the city's housing stock

\footnotetext{
${ }^{79}$ As an officer, Mr Glover received higher military pay. Before the war he earned $f^{6}$ per week as a commercial traveller. OSDWC casefiles, AG-113/080, HL.

${ }^{80}$ This strategy of moving in with other family members to conserve funds was common among Parisian workingclass families. Rollet, 'The Home and Family Life,' 320.

${ }^{81}$ Instances of married women moving with their children to live with parents or parents-in-law after their husband's mobilisation were also commonplace in European cities during the war. Ibid., 320-321.

82 OSDWC casefiles, AG-113/040, HL.

83 OSDWC casefiles, AG-113/100, HL.
} 
by the end of the war: a predisposing factor for poor health and the spread of infectious disease. $^{84}$

For other families war precipitated a downwards step on the property ladder. Two applicant families reported having sold their home upon their husband's departure, prompting their entire household to shift into rental accommodation. Three couples in the sample sold farms or relinquished employment as farm managers for the husband to enlist. In these cases, the husband's decision to enlist deprived his family not only of his income but of their accommodation. By September 1916, Annie Gifford, former owner with her husband of a farm in Middlemarch, was living with their five children in two rooms of a rented house in Dunedin. The couple had salvaged little from the sale of the farm, while the Committee's secretary wrote to her husband David Gifford to enquire why his allotment to his wife had ceased after only one week. ${ }^{85}$ Jessie Holt, who applied for the Society's assistance in September 1918, had been, up until the time her husband was called up, living with her husband as farm managers at a Stoneburn farm. Upon her husband's departure for camp, she and her child had moved into Dunedin to board in the home of a sister-in-law in South Dunedin. The society granted her a weekly allowance to cover her board until her husband's allotments began to arrive. ${ }^{86}$

Other families sought to supplement their incomes through a strategy commonly adopted by working-class widows or deserted wives: that of letting a room in exchange for board or to spread the cost of rent. ${ }^{87}$ Among the 202 applicants for assistance included in this chapter's analysis, 17 had one or more resident boarders, while 28 were boarding themselves. However, the casefiles suggest that even this common strategy for augmenting working-class incomes was threatened by the war, as the young single men who made up the bulk of the boarding population were the same cohort most likely to be mobilised overseas. One soldier's relative impacted by a change in boarding patterns was Mrs Hannah Callaghan. Mrs Callaghan was a soldier's wife, living in Roslyn, where her husband had, before his mobilisation, been employed at the Roslyn Mills. She informed the OSWDC in June 1916 that for the past 13 years she had had 'a young man staying with her...paying $\AA^{1} 1$ in board' but he had enlisted, depriving

${ }^{84}$ In Dunedin, 7,179 people (or $10.85 \%$ of the total population), were classed as living in overcrowded conditions in 1921. Results of a Census of the Dominion of New Zealand Taken for the Night of $17^{\text {th }}$ April, 1921 (Wellington: Government Printer, 1925), part xv, 16-17.

85 OSDWC casefiles, AG-113/080, HL.

86 OSDWC casefiles, AG-113/070, HL.

87 Paul Husbands, 'Poverty in Freeman’s Bay 1886-1913,' NZJH 28, no. 1 (1994): 16-17. 
her of a stable source of household income. ${ }^{88}$ The pre-war income of Mrs Steel, a soldier's mother, entirely disappeared after all sixteen of her boarders enlisted. Before the war, Mrs Steel had been able to make ends meet through the income from her boarders, as well as help from her two sons, both soldiers. But the departure of all her boarders for the front by December caused her to give up her boarding house altogether, and move to share a rented property with her two daughters, whose husbands were both on active service. ${ }^{89}$

Another strategy for augmenting reduced wartime incomes was through taking additional paid employment. It was already common for unmarried or widowed women to contribute to family incomes in this way before the war, and many such women made significant contributions to household incomes, despite the fact that women earned, on average, only a third to a half of an adult male wage. ${ }^{90}$ It took the combined earnings of three daughters of Provo Freeman, discharged from the army in 1917 after losing his eye, to match what would have been standard earnings for one adult male labourer. Clara, Claudine and Freda Freeman, working as a dressmaker and typists respectively, added a combined total of $f^{2} 12$ s per week to the household income, helping to support both their parents and three younger siblings at school through their earnings. ${ }^{91}$

Greater barriers and social stigma stood in the way of married women who sought to supplement their family's income through paid work. By 1914, Olssen writes, 'a wife's respectability, and her husband's had come to depend upon her not having to seek paid work'. ${ }^{92}$ Only the very poorest married women took on paid employment in the decades before the war. Out of the sample of 125 soldiers' wives surveyed for this chapter, only eight listed their own wages as part of their household income. However, the OSDWC's casefiles are not necessarily a reliable indicator of the numbers of married women who took on paid work as a response to their husband's enlistment, as such women were less likely to have approached the OSDWC for help in the first place. Indeed, some married women only applied for the OSDWC's assistance after having been first forced to give up their paid employment. Mrs Jessie Reeves and her 11 month old baby were boarding with her sister in Dunedin while her husband William was away

\footnotetext{
88 OSDWC casefiles, AG-113/125, HL.

89 OSDWC casefiles, AG-113/125, HL.

90 Cooper and Horan, 'Down and Out on the Flat,' 217.

91 OSDWC casefiles, AG-113/060, HL.

92 Olssen, 'Working Gender, Gendering Work,' 60.
} 
at the front. A job at the Paper Mills initially covered the cost of her board, but she had been forced to leave this employment after the baby contracted whooping cough 'because her sister cannot undertake further charge of the baby who needs his mother's attention'. ${ }^{93}$ After her husband's death at Gallipoli, Catherine Durante at first supplemented her military pension by 'going out washing and working by day', but was unable to continue this work after her health 'broke down'. She applied for the OSDWC's assistance only after going to the desperate measure of pawning household goods. The committee promised to grant her a month's rent, redeem the pawned items and enquire to the Pensions authorities as to why her pension was so low. ${ }^{94}$

In cases like that of Jessie Reeves, it is difficult to determine whether taking on paid employment represented a new strategy brought on by the circumstances of war, or the continuation of an existing one. The latter was almost certainly the case for soldier's wife Marion Vincent, whose husband's neglect was of long standing. A 22-year-old mother of two, Mrs Vincent approached the Committee for assistance in May 1916 after learning that her husband, who had deserted her 3 years previously, had enlisted in England as a single man. He had written to his wife but sent no money and, as the visitor in this case reported 'he does not in his letters address her as his wife'. ${ }^{95}$ Unable to receive a separation allowance from the Imperial authorities on the grounds that her husband did not support her before the war, Mrs Vincent supported herself by caring for an invalid woman while sending one of her two children to live with her husband's family and the other to live with her own. By April 1917, Mrs Vincent had moved to live in her mother's house with one of her two children and was earning $f_{1} 1$ per week working at the Phoenix factory, while paying for her other child to be boarded out elsewhere in Dunedin. ${ }^{96}$ In cases such as that of Elizabeth Murray and her three young children, left in 'a most destitute condition' when her husband Alexander Murray enlisted in November 1915, men's departures may have been welcomed by their family members: Murray's abusive treatment of his wife is documented in a series of court cases noted on his OSDWC file in the 1920s. ${ }^{97}$

\footnotetext{
93 OSDWC casefiles, AG-113/100, HL.

94 OSDWC casefiles, AG-113/125, HL.

95 OSDWC casefiles, AG-113/060, HL.

96 Ibid.

${ }_{97}$ OSDWC casefiles, AG-113/045, HL.
} 


\section{Working class men and domestic identities}

The correspondence from soldiers and their families preserved in the records of the OSDWC contains evidence of a range of attitudes to domesticity among the workingclass men whose families the Committee assisted during the war. Some men, such as E. J. Reynolds, believed their foremost duty lay at home. Reynolds was a married man without children whose name was drawn in the ballot for military service early in 1918 . Like many men whose cases are reflected in the casefiles, his preparation for departure to camp had involved a trip to the patriotic society offices to secure financial assistance for his wife. This visit was followed in Reynold's case by a letter enquiring as to why the OSDWC's promised financial help hadn't eventuated. 'Sir some time ago I asked your Society to help my wife when I was in Camp and you promised me that you would do so... the day that I left Dunedin I informed Miss Downie Stewart of my circumstances and I was promised by her that my wife would have your attention. I left my wife without a penny and she would have starved for all she has got from the Society. I myself sent her my first pay and had to go short myself for a lot of nessesary [sic] gear that the average soldier gets when he first enters camp'. His letter spelt out clearly the order of his priorities: 'now Sir I hope you will give this your attention as my wifes [sic] welfare is my fist [sic] consideration, ${ }^{98}$

Jack MacManus was an Otago soldier with whom Mary Downie Stewart maintained a correspondence during the war. ${ }^{99}$ MacManus volunteered for the army and went into camp in 1915, leaving behind his pregnant wife and young family. His friend and fellow labour supporter Jack McCullough reacted with shock to the news of his friend's enlistment and made clear his views that MacManus was irresponsible to volunteer given his heavy family commitments. McCullough recorded in his diary. 'It was a great shock to find him having enlisted...I told him he ought to be spanked, for leaving his wife \& three children \& another one expected. He tried to explain that he felt he would be a coward if he haden't [sic] done it because he was against compulsory service'. ${ }^{100}$ While men such MacManus placed their duty to the war above their existing obligations to family through the action of volunteering, their ties to their families and their commitment to domestic identities did not necessarily lessen with their departure

\footnotetext{
98 OSDWC casefiles, AG-113/125, HL.

99 John MacManus, an Australian-born Catholic of Irish extraction, and a committed unionist and Socialist, had contested the seat of Dunedin South for Labour in the 1911 election. Olssen, Building the New World, $207-211$. 100 Nolan, $W$ ar \& Class, 315-316. McCullough reacted similarly when he learned his old friend Jack Carey planned to volunteer, writing 'I told him, that I thought this was quixotic \& unfair to his wife \& his Neice [sic] for whom he is responsible'. Nolan, War \& Class, 318.
} 
for war. MacManus is revealed in his letters to Mary as a loving and attentive father, keen to stay abreast of his family's affairs from afar. Mary's letter to MacManus recounting her visit to his wife and children was 'more welcome than you can imagine':

Her bravery, and good spirits you tell me she was in, has cheered me very much. I have been writing long letters two and three times a week designed to interest and cheer her. But, perhaps, the happiest feature in your letter was the description of Jack's glee with his birthday gifts. Mrs MacManus told me all about them, and when I read your letter too I caught the thrill of it all. The mental picture I conjured up of that little scene brought back so many happy recollections of such scenes in peaceful times, when Mrs MacManus and I have both been overjoyed with the happiness of the children. ${ }^{101}$

Private B. Smith, a former draughtsman who enlisted in the army in 1916, was deeply concerned with his mother's wellbeing, and valued his correspondence with Mary as a source of reliable news of her state of mind and health: "Thank you so very much for letting me know how Mother is getting on. I really cannot tell you how much pleasure your letter gave me. As you can readily understand she is constantly in my thoughts and knowing how apt she is to worry - it was a great relief to learn that all is well with her. I am sure your visit must have afforded her much pleasure. ${ }^{102}$

Soldiers' letters to the OSWDC's visitors also reveal their keen desire to stay involved in their families' financial affairs from a distance - and the quasi-familial role played by the OSWDC and its visitors in enabling men to enact their domestic roles from afar. ${ }^{103}$ In a June 1916 letter expressing his gratitude for the OSDWC's assistance in paying his wife's rent, covering her maternity home expenses, and arranging for free medical treatment for his children, MacManus also sought Mary's help to recover some missing payments of the government's children's allowances owed his wife. ${ }^{104}$ A similar wish to remain involved in his wife's financial affairs through the conduit of the patriotic society's visitors emerges from the letters of Lieutenant W. J. Dewitt to

101 J. E. MacManus to Mary, 15 October 1916, MS-0985-051/015, HL.

102 Sydney B. Smith to Mary, 12 August 1918, MS-0985-051/016, HL.

${ }^{103}$ Further evidence of soldiers' efforts to obtain sufficient financial support for their families is seen in newspaper reports of the proceedings of the Employment and Relief Committee, such as in a letter 'from a member of the Third Reinforcements as to sufficient relief being provided for his wife and children' received at its January 1915 meeting. 'Employment and Relief Committee,' Otago Daily Times, 23 January 1915, 13.

104 J. E. MacManus to Mary, 5 June 1916, MS-0985-051/015, HL. 
Reverend Cumming. ${ }^{105}$ In a July 1916 letter Dewitt spelt out to Cumming the level of concern he felt in reading of his wife's troubles at home while he was at the front:

I have just received a letter from my dear Wife \& she has told me of your kindness to her \& I wish to thank you for your most generous allotment to her. You can hardly know what it is to be out here in the firing line especially at night time when we have our own thoughts to ourselves \& we have just received a letter from home saying what a struggle it is to keep things going on the small amount they receive from the government allotment I left $4[\mathrm{~s}] \&$ the married man's allowance $1[\mathrm{~s}]$ which made it $5[\mathrm{~s}]$. I am only drawing $1[\mathrm{~s}]$ a day myself \& we have to use nearly the whole of that in supplementing rations we are very often short. ${ }^{106}$

After contrasting his own financial restraint with other soldiers' more careless use of money, Dewitt concluded by acknowledging the 'kindness shewn to my Dear Wife' by the patriotic society: 'It is a great relief to me I can assure you being so far away $\&$ know that she is being taken care of $\&$ that she is not wanting for anything., ${ }^{107}$

By contrast, other men whose families came into contact with the OSDWC are revealed as unreliable providers who may have seen the war as an opportunity to abscond from domestic responsibilities. Some soldiers' families came to the OSDWC's notice after soldier husbands failed to allot their wives sufficient money out of their military pay. Mrs Letitia Craig was the wife of a Wellington soldier who had moved with her young children to Dunedin to be near her sister. When Mary Downie Stewart visited her in February 1917 she was frank about her husband's shortcomings as a provider: 'She says he has a very happy go lucky nature \& does not realise his responsibilities at all'. ${ }^{108}$ In such cases, the OSDWC sometimes worked in conjunction with camp authorities to attempt to compel men to allot money to their wives. ${ }^{109}$ Sergeant William Reeves, a married man who entered military camp in July 1916 had, by September, failed

\footnotetext{
${ }^{105}$ Husbands in this position, as Coralie Clarkson suggests, may have felt anxiety over their wife's apparent ability to cope without them and may have wished to stay closely involved in their family's financial affairs for this reason. Clarkson, 'The Realities of Return,' 34. 106 OSDWC casefiles, AG-113/025, HL.

107 Ibid. This letter was among the last Dewitt wrote: he was killed at the Somme less than two months later. 108 OSDWC casefiles, AG-113/065, HL.

${ }^{109}$ Of the 86 soldiers for whom the OSDWC recorded information on allotments, close to half (48.8 per cent) left their wives the recommended rate of $4 \mathrm{~s}$ per day. A significant number (42 percent) left less: 27 soldiers (31.4 percent) left $3 \mathrm{~s}$ per day, and 2 soldiers left less than 3s. 9.4 percent of soldiers left more than $4 \mathrm{~s}$.
} 
to forward any money for his wife's support - in spite of repeated entreaties from his wife and her sister. In his case, the secretary of the patriotic society wrote directly to the Camp Commandant at Featherson to demand that Rockliffe immediately sign an allotment to his wife. Reeves eventually alloted the recommended $4 \mathrm{~s}$ per day to his wife's support. ${ }^{110}$

As Marina Larsson has found, men's decisions to enlist frequently took place in family contexts. ${ }^{111}$ Archibald Price, a married father of one, signalled to the Committee that he intended to enlist in April 1916. A note on his file several months later recorded that Price had 'No intention of going at present wife objects'. In Price's case, his wife's opinion appears to have carried weight and this married father of one did not enter camp until September 1918, probably after being conscripted. He was still in camp when the war ended. ${ }^{112}$ Another married father of one, Sydney Gilchrist, volunteered for military service and was due to embark for military camp in January 1917. However, his wife was 'objecting strongly to husband going' and Gilchrist enlisted the assistance of one of the Committees' visitors to persuade her to change her mind. His wife's objections, and possibly also her husband's decision to enlist, probably stemmed from the family's precarious financial situation at the time. At the time Sydney Gilchrist visited the Committee, he had been out of work for five weeks, and the family were in arrears on both rent and gas for the single furnished room they rented in Dunedin. ${ }^{113}$ Gilchrist went on to enlist, while the Committee agreed to grant his wife an allowance, although he never left New Zealand, having suffered a nervous breakdown in camp. ${ }^{114}$ As Gilchrist's case also suggests, the patriotic committee themselves sometimes became a party in families' decision making over enlistment.

In other cases a husband or father's enlistment could in no way be construed as a family decision owing to the complete ignorance of a man's family that he had enlisted. When Arthur McKenna enlisted with the $2^{\text {nd }}$ Reinforcements he did not even inform his wife Edith, and left his allotment to his mother, who he named as his next of kin. ${ }^{115}$ Frances James Steel made her husband's lunch for work as usual one morning,

\footnotetext{
110 OSDWC casefiles, AG-113/100, HL.

${ }^{111}$ Larsson writes that 'While some men joined up without consulting their kin, the decision-making process was often family-based'. Larsson, Shattered Anzacs, 31.

112 OSDWC casefiles, AG-113/090, HL.

113 OSDWC casefiles, AG-113/050, HL.

114 Ibid.

115 OSDWC casefiles, AG-113/125, HL.
} 
but that evening he did not return home. Instead of going to work he had travelled to Wellington and enlisted as a single man under an alias, Frederick Smith. Mrs Steel subsequently left their child in the care of his mother and travelled to Wellington to find her husband. ${ }^{116}$ Instances of men enlisting as single without their wives' knowledge were sufficiently common that camp authorities found it necessary to issue special camp passes to wives wishing to enter the camps to search for their husbands. ${ }^{117}$

Relationships suffered from the lengthy separations of wartime. A 1916 letter from Mary Downie Stewart to her sister Rachel portrayed encounters with unfaithful wives as virtually an everyday occurrence in her visiting work: 'Today I had to go \& look into a case where a wife had been turned out by the landlord, because of her evil living, \& he said he thought she was going to have another child. This I found to be quite true \& yet her husband left N.Z. May 1915! This is the $2^{\text {nd }}$ case on much the same lines, today. ${ }^{118}$ Hayley Brown's research suggests that a postwar increase in New Zealand's divorce rates cannot be attributed to the impact of wartime separations alone, owing to the low proportion of married men in the armed forces. ${ }^{119}$ However, the war was a contributing factor in the breakdown of some relationships among OSDWC applicants. Herbert Cooper and his wife ended their six year marriage upon his return from the war in 1918. A letter from his wife on his personnel file gives provides an explanation for the separation: 'My husband lived with another woman in England and on returning to Dunedin did not come near his wife and 2 children but started going round with another woman so I was forced to get a separation with maintenance. ${ }^{120}$

\section{Return home}

This chapter's focus has been on the period from 1914 to 1919, but families' burdens did not necessarily ease upon a soldier's return. For some families, the adjustments imposed upon them by war proved long-lasting and even permanent. Eight years after Otago soldier Charles Goodwin was discharged from the army suffering from a head wound, he and his wife and family were still living with and being supported by Goodwin's mother. ${ }^{121}$ Sixteen-year-old Elsie Irving was forced to stay at home to care

116 OSDWC casefiles, AG-113/125, HL.

117 Tennant, Paupers \& Providers, 109.

118 Mary to Rachel, c. 1916, MS-0985-040/003, HL.

${ }^{119}$ Hayley Brown, 'Loosening the Marriage Bond: Divorce in New Zealand, c. 1890s to c. 1950s,' (PhD Thesis, Victoria University of Wellington, 2011), 75.

120 OSDWC casefiles, AG-113/090, HL.

121 OSDWC casefiles, AG-113/050, HL. 
for her father William, who returned from the war in November 1918 in 'feeble health'. ${ }^{122}$ War-related injuries caused strains in family relationships. Charles Robinson, who returned wounded, was reported by his brother to have become 'very nervy \& hard of hearing' as a result of his war injuries. This created strain in their family home. '[F]or the last 4 weeks or so he imagins [sic] I'm talking about him when he can't hear the conversation between my Mother \& Myself \& he reckons he is going to pack up \& go away shortly. He is not well enough to go far from home \& needs looking after'. ${ }^{123}$

After the war, the patriotic societies continued to provide essential support to some soldiers' families. Some of the families assisted by the OSDWC in this way were those who were, for various reasons, ineligible for government pensions. Palmerston soldier Hunter Towers, a married man with four children, was supported by the local patriotic society after he was denied a pension on the basis that his wound was selfinflicted. The secretary of the local branch of the patriotic society sympathised that: "Whether the wound was self inflicted or not the fact remains that had this man not gone to the Front he would be in a position to keep his wife \& family'. ${ }^{124}$ Even families eligible for a government pension sometimes found it difficult to make ends meet. Soldier's widow Mrs Guthrie, who came under the notice of the OPGWA's Owaka branch, struggled to keep herself and her six children on the government's pension. 'Mr Guthrie was killed some time ago and Mrs Guthrie is in receipt of a pension at the rate of $£ 104$ per year out of which she has to keep herself and six children and my committee would recommend a small weekly allowance to help her to pay rent etc'. ${ }^{125}$ Returned soldier, Steven O'Reilly was denied a military pension on the grounds that he could not prove that his rheumatism - which rendered him unable to work - was attributable to the war. The OSDWC appointed a physician to testify to the War Pensions Board on O'Reilly's behalf. However, while the doctor attested that O'Reilly 'was fit on joining the army \& had no history of rheumatism,' the Board refused to budge from its initial position that 'there is no record of this man having suffered from Rheumatism... while a member of the NZEF. ${ }^{126}$

\footnotetext{
122 OSDWC casefiles, AG-113/070, HL.

123 Thomas Robinson requested a grant for mining equipment. 'In order to relieve the situation I want to go to Central Otago in search of work \& a bit of Prospecting'. OSDWC casefiles, AG-113/110, HL. 124 OSDWC casefiles, AG-113/120, Hn.

125 The committee granted $£ 25$ and a loan of the same amount. OSDWC casefiles, AG-113/024, HL. 126 OSDWC casefiles, AG-113/100, HL. For a further example of a returned soldier denied a pension due to being unable to convince the pensions authorities of the link between his arthritis and war service see Boston, "The Bacillus of Work", 41.
} 
The echoes of O'Reilly's case will be seen in the next chapter, as William Downie Stewart was also invalided home suffering from rheumatism. Wounding, sickness and deaths cut across all classes of men during the war creating a set of shared experiences regardless of their aftermath. It is in exploring the parallels between families such as the Stewarts and those most vulnerable in their community that class becomes an important factor in New Zealand's war experience. Those individuals or families who shifted residence after the departure of one or more soldier family members for war provide a parallel yet markedly contrasting instance of wartime mobility to that represented in chapter two. Accusations of self-interest, outlined in chapter one, directed at mothers or wives perceived as holding back their sons or husbands from enlisting, appear in a different light when viewed against many families' struggles to make ends meet after the departure of their male relatives for war. Those who were perceived as having enlisted selflessly, even at great cost to their families, were generally looked upon favourably by the OSWDC.

Not all men accepted the middle-class perspective that prioritising their family obligations over their duty to the war effort represented a selfish act. Other workingclass men voluntarily enlisted, but displayed a keen desire to stay actively involved in their families' affairs from afar. Here, the patriotic society and its representatives performed a key role as intermediaries between men and their families by providing reliable accounts of their families' wellbeing or acting on their behalf in their financial affairs. Their letters to patriotic society visitors, like the soldiers' letters to their families which form the subject of Meyer's work, formed 'spaces in which [men] continued to assert their claims to domesticity'. ${ }^{127}$ But not all men proved to be reliable breadwinners, and the plight of at least some soldiers' families can be explained through the reluctance of husbands, fathers or sons to allocate money from their military pay for their families' support. Other men appear to have seen the war as an opportunity to escape family ties altogether. In the cases of these and other families, the separations of war created a permanent breach in family relationships. Chapter six advances this chapter's theme of the long-lasting readjustments to family life, as well as tracing the continuing permutations of wartime duty after the war, by focusing on the case of William Downie Stewart and the familial experience of disability.

${ }^{127}$ Meyer, Men of War, 46. 


\section{CHAPTER SIX}

\section{'OUR GREAT SEARCH FOR HEALTH': WILLIAM DOWNIE STEWART'S DISABILITY.}

At midday on 19 December 1916, the hospital ship Mabeno berthed at Auckland's Queen's Wharf, bearing a cargo of 376 sick and wounded soldiers home from the front. Waiting friends and family crowded around, eager to catch a first glimpse of their own 'gallant fellow' as the local men walked, or were assisted, off the ship. An Auckland Star reporter captured the occasion's mixed mood when he contrasted the 'bright and cheerful' tone of the crowd's welcome with 'the inevitable atmosphere of pathos that must surround the home-coming of a hospital ship'. Family members 'hastily dashed aside' tears to mask the 'shock of meeting a sadly-altered son or husband'. 'The 'signs of the battlefield' were palpable on the bodies of the 150 men who disembarked the Maheno in Wellington two days later, 18 among them 'cot cases'. 'The 61 'maimed or wounded' men who left the ship in Christchurch were landed 'without ceremony' and transported to their various destinations, including seven seriously unwell men taken directly to hospital by ambulance, before the ship departed for its final destination of Port Chalmers, Dunedin. ${ }^{3}$

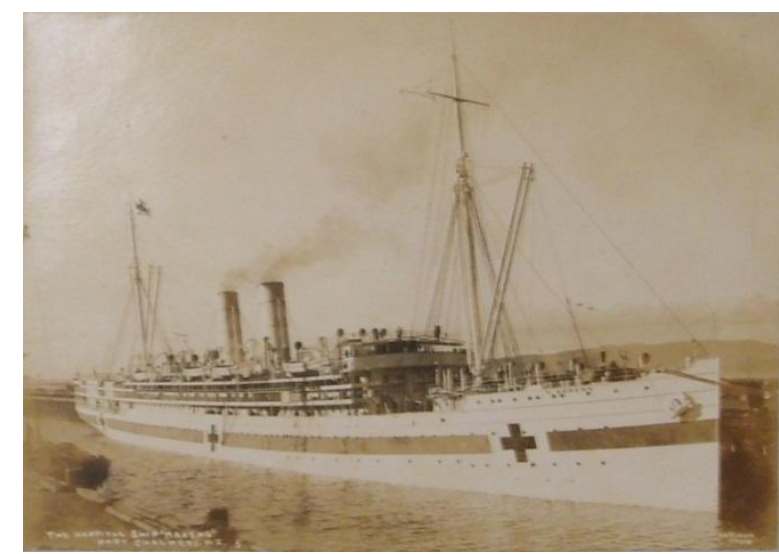

Figure 6.1: The Maheno at Port Chalmers. ${ }^{4}$

\footnotetext{
1 'Somme Heroes,' Auckland Star, 19 December 1916, 6.

2 'Maheno Arrives,' Dominion, 22 December 1916, 8.

3 'The Maheno,' Press, 23 December 1916, 6.

${ }_{4}^{4}$ MS-0985-056/014, HL.
} 
On 23 December, Mary Downie Stewart and Rachel Armitage were among the crowd that awaited the Maheno's arrival at Port Chalmers wharf with anticipation and trepidation. Their brother William Downie Stewart was among 70 returned Otago and Southland men who arrived home that day. Prior to the ship's arrival, the two sisters' hopes for their brother's recovery may have been buoyed by an optimistic letter from their sister-in-law Elizabeth Stewart, in which she predicted that the sunshine and sea air of the voyage would surely work wonders for William's health: 'I hope to hear from you that he is able to walk off the boat with very little assistance'. William's statement to an Auckland newspaper reporter that he had 'benefited considerably from the voyage' and 'lately been able to walk about the deck of the vessel' probably also boosted Mary and Rachels' hopes. ${ }^{6}$ The sight of William being carried off the Mabeno on a hospital stretcher must therefore have come as a sore shock to his sisters.

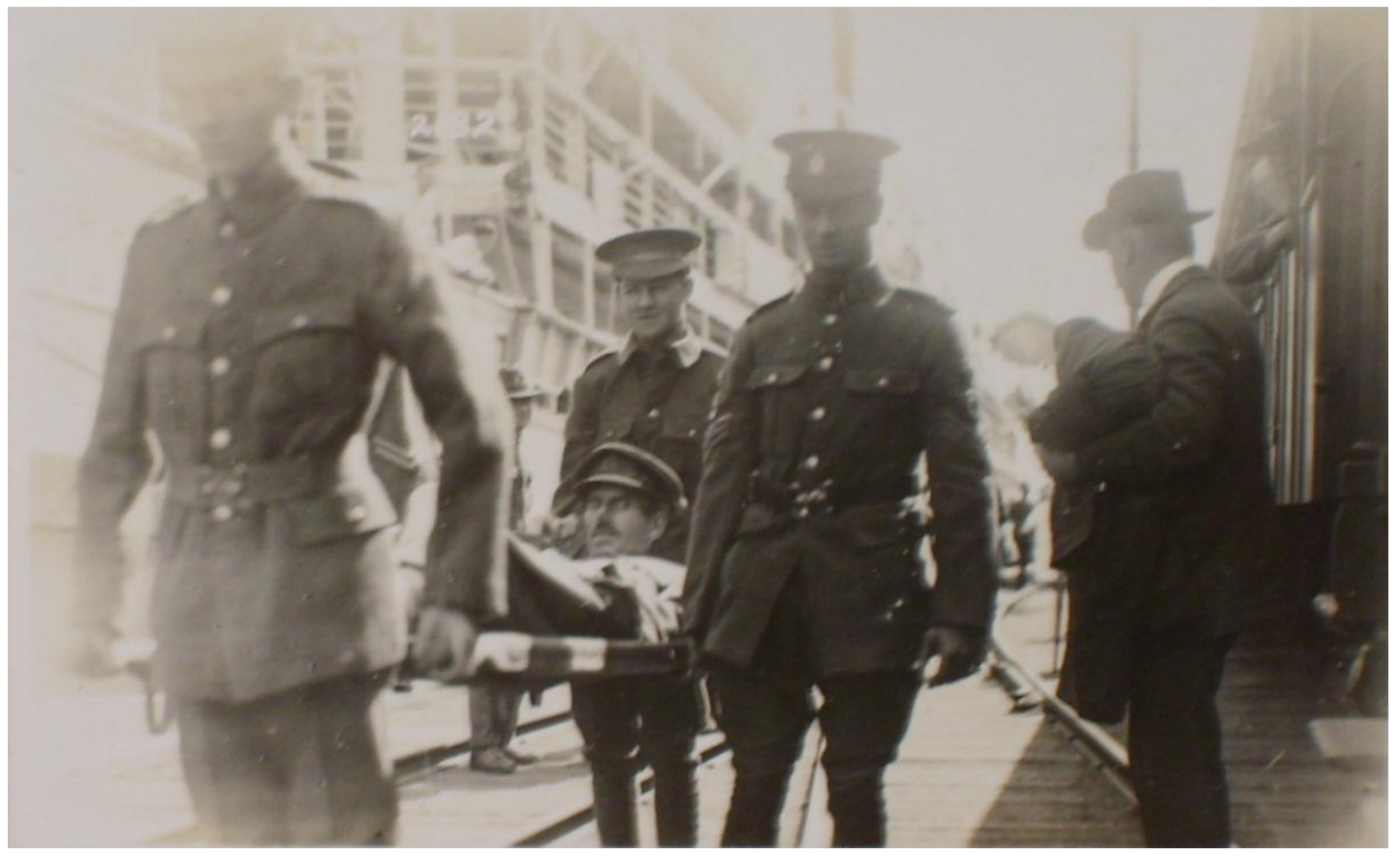

Figure 6.2: William being carried ashore from the Maheno at Port Chalmers, December 1916

Source: MS-0985-057/040, HL.

\footnotetext{
${ }^{5}$ Elizabeth to Mary and Rachel, 31 October 1916, MS-0985-041/002, HL.

6 'Back From The War,' Otago Daily Times, 20 December 1916, 7.
} 
From the time the first news of William's illness reached his family members in New Zealand his medical condition became the concern of his entire family. After his return, his reliance upon others for assistance with mobility and with the most intimate aspects of his daily care transformed his relationship with his sisters, particularly Mary, who became her brother's primary carer until his death in 1949. Mary also became her brother's travelling companion in his search for health which, between 1916 and 1932, would see them visit three continents and consult dozens of medical specialists, as well as some less orthodox healers, in the quest for a cure. ${ }^{7}$

The 376 sick or injured men who returned upon the Mabeno were only a fraction of the total 41,317 men who returned to New Zealand suffering from wounds or illness. ${ }^{8}$ What set William apart from other disabled soldiers was that his subsequent successful career as a politician and cabinet minister placed him almost continuously in the public eye during the 1920s and 1930s. In these decades, William and a handful of other disabled returned servicemen in Parliament were probably the most prominent disabled men in public life. Their portrayal presents an opportunity to examine attitudes to masculinity and disability in a period in which, historians suggest, the process of postwar recovery rendered disabled veterans virtually invisible in the public sphere. ${ }^{9}$ During this period, the chapter argues, the earlier war service of veteran MPs like William Downie Stewart was depicted in consistently embodied terms, with their bodily afflictions ascribed meaning in light of their earlier war service. Drawing upon the public representation of William and his fellow veteran MPs, the chapter argues for the enduring power of ideals of duty and military sacrifice well beyond the point by which they are popularly believed to have dissolved into disillusionment.

After the war, the main duty of disabled veterans was to maintain a positive attitude and make the successful transition to employment and the adult masculine status of breadwinner and provider. By contrast, after the war, the primary duty of female relatives in the households of disabled soldiers became that of caring for disabled men and assisting them on their journeys to masculine 'independence'. In juxtaposing

\footnotetext{
${ }^{7}$ Historian Maria Frawley coined the term 'search for health' to document the journeys of nineteenth-century British invalids in search of a cure. Maria Frawley, Invalidism and Identity in Nineteenth-Century Britain (Chicago: University of Chicago Press, 2004).

8 McGibbon, ed., The Oxford Companion to New Zealand Military History, 80.

${ }^{9}$ Seth Koven argues that the 'process of postwar reconstruction required that societies allow themselves to forget the wounds of war so that these could begin to close, to be concealed'. Seth Koven, 'Remembering and Dismemberment: Crippled Children, Wounded Soldiers, and the Great War in Great Britain', The American Historical Review 99, no. 4 (October 1994): 1169.
} 
these two contexts of disability - the familial and the public - this chapter suggests that a disjuncture exists between the two. In praising the achievements of high-profile disabled men and emphasising the individual willpower involved in 'overcoming' disability, their public portrayals seldom recognised the family labour that underpinned their successes.

\section{Background}

The earliest signs that all was not well with William's health appear in his war diary entry for 25 June 1916, written from the front in France: 'During last night I had rheumatism in the shoulders so bad that I could not sleep - I sent for the doctor at 4am \& he gave me some morphia - The pain died down during the morning \& except that my arms are very stiff I was all right. Stayed in bed all day. ${ }^{10}$ By 16 August 1916, William’s condition had come to the attention of his military superiors, and Major-General Russell informed him 'Downie I think you should go to N.Z. If you are screwed up with rheumatism in the summer you will be worse in winter. You have set an example \& done your job \& I think you are wasting your time as a platoon commr. You will be of far more national service in N.Z."11 Three days later William received a note reading 'unfit for service suffering from arthritis - recommended for Spa treatment in England'. ${ }^{2}$ William arrived at Dover late morning on 24 August and after a train-journey to London's Charing Cross station, was deposited at the $4^{\text {th }}$ General London Hospital at Denmark Hill. ${ }^{13}$ William found the experience of being transported from France in the company of wounded men returning from the Somme deeply shameful. His embarrassment intensified when, after leaving Charing Cross Station, his car was 'showered with roses' by the waiting public, 'as people evidently assumed we had all been in the heavy fighting at the Somme'. ${ }^{14}$ William's sisters in New Zealand first learned of his hospitalisation from a cable from London dated 30 August 1916: 'Will be in England some weeks treatment for rheumatism slight but persistent'. ${ }^{15}$ Shortly afterwards, Mary arranged

\footnotetext{
10 William Downie Stewart, war diary, 25 June 1916, MS-0985-008/001, HL. T. E. Y. Seddon's autobiography suggests that William experienced the first bout of his illness while serving on 'the damp banks of the Suez Canal' in Egypt. At Armentières, William confessed to Seddon that he was having difficulty marching due to the pain in his hips. Seddon, The Seddons, 240-241.

11 William Downie Stewart, war diary, 16 August 1916, MS-0985-008/001, HL. Major-General Sir Andrew Russell commanded the New Zealand Division on the Western Front from May 1916 until the end of the war. McGibbon, ed., Oxford Companion to New Zealand Military History, 472.

12 William Downie Stewart, war diary, 19 August 1916, MS-0985-008/001, HL. William conveyed a similar account of the same events in a letter to Rachel sent early in September. See William to Rachel, 6 September 1916, MS-0985039/003, HL.

13 William Downie Stewart, war diary, 14 August 1916, MS-0985-008/001, HL.

14 William to Rachel, 6 September 1916, MS-0985-039/003, HL.

15 William to Mary, 30 August 1916, MS-0985-051/013, HL.
} 
leave from her OSWPA and visiting duties to travel to England to visit her brother in person, fulfilling a promise made to William upon his departure: if you are wounded \& are sent to England send a cable \& I am coming. ${ }^{16}$

William rapidly grew dissatisfied with the standard of treatment at his London hospital, and began to make arrangements through military contacts for his transfer to a specialist facility: 'I shall be glad to get under treatment, as they are doing very little at Denmark Hill. I suppose they are very short staffed in all the Hospitals, and can only deal with the most urgent cases, because in my own case, and that of a number of other men, a good few days passed before the doctor took any notice of us. He simply walked down the Ward, looked at your card, made some casual remark, and moved on'. ${ }^{17}$ William's ability to seek out better treatment was a marker of his military connections and officer status. In England, while men in the ranks were typically treated in large 'barrack-like' hospitals, most officers received treatment in smaller private homes with higher staff-to-patient ratios and a greater level of comfort. ${ }^{18}$ On 11 September William caught a train to Bath where Colonel Myers, Assistant Director of the New Zealand Medical Corps, had arranged a bed for him at one such private convalescent home. ${ }^{19}$ There, after submitting William's blood for bacteriological analysis, his doctor informed him that: 'in addition to rheumatism I have some form of Trench fever. They do not know much about this fever except that it is probably caused by mosquito bites same as malaria'. ${ }^{20}$ Two days after his arrival in Bath, William lowered himself into the city's famed mineral baths for the first time: 'I think they are doing me good, although at first they make you very stiff and you feel worse than you did before you started'. ${ }^{21}$ But in spite of his initial optimism, William's time in Bath coincided with a marked deterioration in his condition, with swelling and stiffness in his joints causing him increasing discomfort and hampering movement in his limbs. ' [] am a good deal more helpless than when I came' he informed Rachel three weeks after his arrival. ${ }^{22}$ But, he added, with a note of reassurance for his sister's benefit: 'You must not worry about me as my general health is good and I suffer practically no pain. It is only that my muscles

\footnotetext{
16 Mary to William, 5 January 1916, MS-0985-006/004, HL.

17 William to Rachel, 6 September 1916, MS-0985-039/003, HL.

18 Reznick, Healing the Nation, 54-55.

19 William to Mary, 11 September 1916, MS-0985-049/004, HL.

20 William to Rachel, 21 September 1916, MS-0985-039/003, HL. So-called 'Trench fever' accounted for an estimated 20 percent of admissions to casualty clearing stations by August 1918. Kate Blackmore, The Dark Pocket of Time: War, Medicine and the Australian State, 1914-1935 (Adelaide: Lythrum Press, 2008), 45-48.

21 William to Rachel, 21 September 1916, MS-0985-039/003, HL.

22 William to Rachel, 1 October 1916, MS-0985-039/003, HL.
} 
$\&$ joints are very stiff $\&$ swollen $\&$ this handicaps me greatly in doing even the smallest thing. ${ }^{, 23}$

It is probable that William's diary entries from his time in Bath were written retrospectively, as he was by then experiencing difficulty holding a pen. His letter to Rachel of 6 September was dictated to a typist, his signature appended beneath the typewritten text in a shaky hand: 'my right hand has been rather cramped, so I hope you won't mind my sending you a typewritten letter'. ${ }^{24}$ Wary of trusting in William's unwaveringly optimistic accounts of his state of health, his family members placed increasing weight upon what the appearance of his letters revealed of his condition. Here, epistolary form was privileged over content, due to the greater capacity of the latter to mislead. Thus, a letter written in William's own hand became evidence of improvement: a sign that he had regained sufficient dexterity in his hands to compose a letter without the aid of a typist. After receiving a hand-written letter sent during William's voyage home to New Zealand Elizabeth wrote: 'I need not tell you how very pleased I was to get your letter from Albany written by yourself - \& I appreciate, too, the fact that it was your first effort - it proved that you really were better - you see, since those optimistic letters from Bath I have learned to look with a certain amount of doubt on your glowing word pictures of your state of health!! ${ }^{25}$ But upon receiving another dictated letter in May of that year, Elizabeth took it as a sign his recovery had slowed: 'It was so nice to get his (Downie's letter) altho' dictated - by this mail - The few lines in his own hand show the unsteadiness \& helplessness of it still but it was very nice to get them. ${ }^{26}$

\footnotetext{
23 William to Rachel, 1 October 1916, MS-0985-039/003, HL.

24 William to Rachel, 6 September 1916, MS-0985-039/003, HL.

${ }^{25}$ Elizabeth to William, 11 February 1917, MS-0985-007/004, HL.

${ }^{26}$ Elizabeth to Rachel, 5 May 1917, MB-391-4/26, MBL.
} 


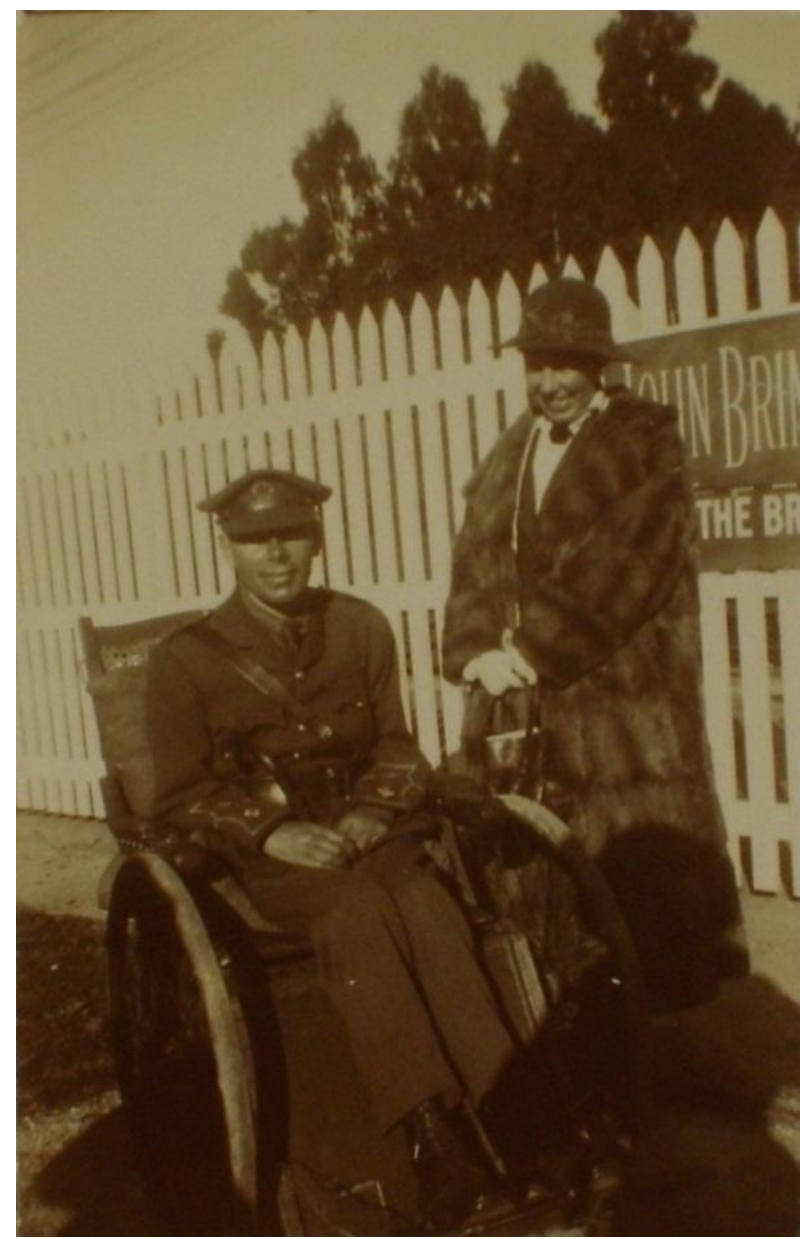

Figure 6.3: William and Mary at Rotorua in 1917

Source: MS-0985-057/040, HL.

No sooner had William arrived back in Dunedin than he and Mary began laying plans to travel to Rotorua to take advantage of the region's 'therapeutic' climate and the bathing facilities offered by the Government Sanatorium, which had, by the time of Mary and William's 1917 visit, been turned over to the control of the Department of Public Health for the exclusive use of convalescent soldiers. ${ }^{27}$ Upon admission to the Rotorua Convalescent Hospital on 19 March 1917, William came under the care of the Government balneologist Dr Arthur Stanley Herbert (or Wohlmann, as he was previously known). ${ }^{28}$

\footnotetext{
${ }^{27}$ For the history of the Rotorua baths and other 'spa resorts' see Ian Rockel, Taking the Waters: Early Spas in New Zealand (Wellington: Government Printing Office Publishing, 1986). For an account of the Bath's history as a favoured haunt for gay men, see Chris Brickell, Mates \& Lovers: A History of Gay New Zealand (Auckland: Random House, 2008), 96-97, 245-248. While William Downie Stewart never married, there is nothing in the family papers to indicate that he was sexually attracted to other men.

${ }^{28} \mathrm{Dr}$ Wohlmann, formerly employed by the Royal Hospital, Bath, was recruited by the New Zealand government to help promote Rotorua as a destination for European health tourists. Margaret McClure, The Wonder Country: Making New Zealand Tourism (Auckland: Auckland University Press, 2004), 22. Wohlmann had changed his name to his wife's maiden name of Herbert during the war to avoid suspicion of German ancestry.
} 


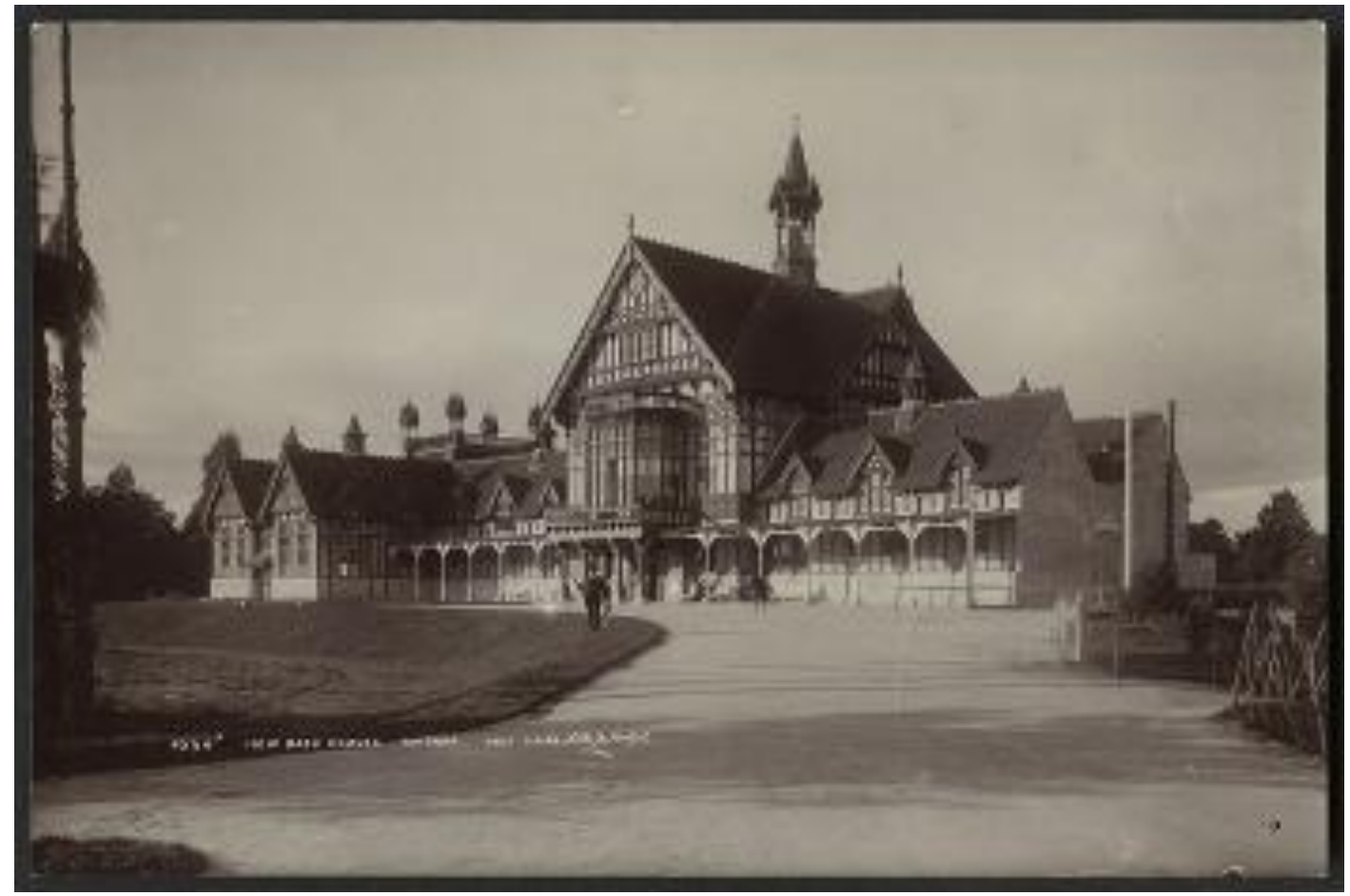

Figure 6.4: Government Baths, Rotorua, 1909

Source: PAColl-7344-79, ATL, URL: http://natlib.govt.nz/records/22321136, accessed 29 March 2014.

While rheumatoid arthritis, the condition that William almost certainly suffered from, is now known to be an auto-immune disease, early twentieth century medical experts attributed it to the work of bacteria disseminating toxins or 'germs' from one or more 'foci' in the body. This explanation of the disease's etiology applied late nineteenthcentury advances in bacteriology or 'germ theory' to a condition that was little understood yet widely prevalent among the population. William's understanding of his condition as attributable to harmful bacterial agents or toxins produced by bacteria is evident in a conversation with his doctor at Rotorua relayed in an April 1917 letter: 'I said I suppose as my general health improves the healthy corpusiles [sic] will fight out the poison ones - He said yes there is a fight going on all the time'. ${ }^{29}$ Having received the diagnosis of 'Toxic Arthritis' William commenced his new treatment regime, comprising thermal baths followed by massages and walks around the Sanatorium gardens, with Mary following behind him with a chair to wheel him if he tired. ${ }^{30}$ Bathing routines were carefully prescribed under Herbert's regime with treatment plans

29 William to Rachel, 25 April 1917, MS-0985-039/004, HL.

30 William to Rachel, 25 March 1917, MS-0985-039/004, HL. 
specifying 'the bath to be taken, the temperature of the bath, time of immersion, nature of the douches, \&c': a controlled regime through which Herbert hoped to distinguish his own scientific methods from the 'indiscriminate and often injurious bathing formerly indulged in by the patients'. ${ }^{31}$ William's 'prescription' involved treatments in the 'Priest Bath': an acidic sulphorous bath thought particularly beneficial for arthritis patients. ${ }^{32}$ However, at the conclusion of three months' treatment at Rotorua, William's condition displayed little improvement, and he and Mary instead turned their attention to overseas specialists.

From Rotorua, William and Mary travelled to Sydney, where William placed himself under the care of arthritis specialist Dr Sinclair Gillies. ${ }^{33}$ Several weeks after 'overhauling' his patient for the first time, Dr Gillies was ready to recommend a course of action. Having examined William's tonsils and found them 'septic', Dr Gillies ordered their removal - in line with the prevailing medical belief that the tonsils frequently formed the main 'septic foci' responsible for disseminating arthritis throughout the body. ${ }^{34}$ By 4 August 1917, the operation was over and pronounced a success. Meanwhile, Dr Gillies had revealed the next stage of his planned treatment: to distil 'the disease on the tonsils' into the form of a serum to be re-injected back into William's body. ${ }^{35}$ ' $[\mathrm{L}]$ et us hope this will be successful', Mary wrote. ${ }^{36}$ A month later, as Dr Gillies prepared to commence injecting a course of vaccines prepared from William's tonsils, Mary predicted: 'I think his prospects of a cure are really more bright than they have ever been. Dr Gillies has a great name in Sydney. He will begin innoculating him this week, with a vaccine prepared from the tonsils, \& I am hoping for great things, ${ }^{37}$ The promised 'great things' did not result and after six months of vaccine treatments and a

\footnotetext{
31 Report of Government Balneologist, AJHR, 1903, H-02, Appendix I, 10.

32 Ibid., 2.

${ }_{33}$ Dr Sinclair Gillies (c. 1869-1939) was a member of the prominent Otago Gillies family. William Downie Stewart senior entered into the legal firm of Sinclair Gillies' father Thomas Ballantyne Gillies, Richmond and Gillies, soon after arriving in Otago in the 1860s; Thomas Gillies later became a justice of the Supreme Court. Sinclair Gillies was also a cousin of Sir Harold Gillies (1882-1960) the renowned plastic surgeon during the First World War. 'Gillies, John (1892-1871),' in Southern People: A Dictionary of Otago Southland Biography, ed., Jane Thomson (Dunedin: Longacre Press, 1998), 184.

34 Charles W. Buckley, 'The Treatment of Arthritis,' British Medical Journal (6 May 1933): 774.

35 A 1933 British Medical Association Committee appointed to investigate the treatment of arthritis recommended vaccines as beneficial in some cases. Patients were inoculated either using stock vaccines or with 'autogenous' vaccines produced from the patient's own body.'Report of Arthritis Committee', British Medical Journal (17 June 1933 ): 1033-1052.

36 Mary to Rachel, 4 August 1917, MS-0985-040/004, HL. For the history of the Blue Mountains and other Australian mountain resorts as destinations for health tourists see Andrea Scott Inglis, Summer in the Hills: The Nineteenth-Century Mountain Resort in Australia (Melbourne: Australian Scholarly Publishing, 2007).

37 Mary to Rachel, 16 September 1917, MS-0985-040/004, HL.
} 
brief sojourn to the Blue Mountains to take the therapeutic mountain air, William and Mary returned home to New Zealand in February $1918 .^{38}$

By the opening of a new Parliamentary session in October 1918, William's health had improved sufficiently to enable him to return to Parliament. In December 1919, he was re-elected as MP for Dunedin West. Over the next few years, in spite of the disadvantages presented by his ongoing ill-health and impaired mobility, William rose rapidly within the Reform Party's ranks and achieved a reputation as one of the most intellectually able politicians in the Reform caucus. Reform colleagues had discussed appointing William to cabinet as early as 1919, although it was not until February 1921 that his party judged his health satisfactory enough to take on his first ministerial portfolio of Internal Affairs. ${ }^{39}$ The same year he was appointed to the senior portfolio of Customs, and in 1923 became Minister of Industries and Commerce. ${ }^{40}$ William's career as an MP and cabinet minister over the next decade was punctuated by lengthy periods of absence as he took leave from his Parliamentary duties to consult overseas medical experts on his condition.

In 1925, after having suffered a deterioration in his health, William took leave from Parliament and travelled with Mary to consult Dr Burbank, a world-renowned specialist said to have had 'singular success in cases of arthritis' ${ }^{41}$ Arriving in New York on 17 March 1925, William and Mary met with Dr Burbank the same day. ${ }^{42}$ William's consultation at Dr Burbank's New York clinic bore all the hallmarks of a modern medical examination, combining a physical examination with laboratory analysis: 'he made a quick but exhaustive examination and took swabs from my throat, gums, etc., and also samples of my blood which is the chief source of his information'. ${ }^{43}$ After bacteriological results identified William's throat as the probable source of the 'germ' in his case, Dr Burbank prescribed a set of vaccines cultivated from bacteria taken from William's throat. The vaccine's immediate result was to cause further inflammation. While William observed that this set back was 'a very severe test of one's patience in the doctor', he remained confident in Dr Burbank's abilities: 'I am satisfied that the doctor

\footnotetext{
38 'Personal,' Otago Daily Times, 8 February 1918, 3.

39 Mary to Rachel, 3 September 1919, MS-0985-040/006, HL.

40 Dale, 'Stewart, William Downie - Biography'.

41 William to Sir James Allen, 25 March 1925, MS-0985-003/038, HL.

42 Ibid.

43 William to Sir Francis Bell, 23 March 1925, MS-0985-003/038, HL.
} 
is a great master of his job and he seems to know everything that is going on inside my body even before I tell him anything, ${ }^{44}$

It was during this New York trip that William received news of the death of New Zealand Prime Minister William Massey. Subsequent debate in the newspapers pitted William Downie Stewart against another returned soldier candidate, Gordon Coates, as the leading contenders to replace Massey as Reform leader and Prime Minister. It is unclear whether or not William wanted the leadership and would have accepted if offered it. ${ }^{45}$ Most commentators acknowledged that his absence from New Zealand and his poor state of health would likely disqualify him from the leadership. As the Evening Post put it, while Coates was widely regarded as the favoured contender: 'if the physical health of Mr Downie Stewart bore any relation to his mental qualities, and Mr Stewart were on the spot, a different trend might be taken by the predictions. ${ }^{46} \mathrm{By}$ the middle of June, with political events back in New Zealand weighing heavily on William's mind, and little discernible improvement to show from the vaccines, he resolved to cut their trip short. 'So we turn homewards from our great search for health', Mary wrote, 'with very heavy hearts'. ${ }^{47}$

While Coates was appointed Prime Minister as predicted, William accepted responsibility for the senior portfolios of Finance and Customs, but turned down the Attorney Generalship, feeling 'it was a portfolio that needed legs'. ${ }^{48}$ Reform lost the election of 1928, but William returned to Parliament and resumed the Finance portfolio after Reform entered into a coalition with the United government in 1931. It was in his capacity as Minister of Finance that William travelled to Canada, with Mary and their nephew Stewart William Armitage, to attend the 1932 Ottawa Trade Conference. ${ }^{49}$ William had written to Burbank in advance of their trip, and the doctor informed him that his clinic 'had made great strides in their work' since 1925 and were 'very hopeful about being able to do something, ${ }^{50}$ While in Canada, William and Mary also took advantage of a break in the conference to travel to Williamsburg, Ottawa, to visit a 'Dr

44 William to Gordon Coates, 27 March 1925, MS-0985-003/038, HL.

${ }^{45}$ Dale, 'Gentleman of Politics', 62. For an account of the succession see Michael Bassett, Coates of Kaipara (Auckland: Auckland University Press, 1995), 89-93.

46 'Dual Leadership,' Evening Post, 23 May 1925, 8.

${ }^{47}$ Mary to Rachel, 17 June 1925, MS-0985-040/010, HL.

48 Mary to Rachel, 23 May 1926, MS-0985-040/011, HL.

${ }^{49}$ William had commenced negotiations with the Canadian Trade Minister on a brief trip to Honolulu in 1931 where he bathed in the island's 'tepid waters'. Mary had also accompanied him on this voyage. Mary to Rachel, c. June 1932, MS-0985-040/012, HL.

50 Mary to Rachel, 7 August 1932, MS-0985-040/012, HL. 
Locke', a podiatrist who claimed to effect miracle cures for arthritis sufferers: 'he is I suppose what is called a Quack', Mary wrote, but 'he does some marvellous cures.. ${ }^{51}$ Mary and William had been prompted to visit Dr Locke after reading an article back in New Zealand on his healing powers, as well as 'having heard a great deal since coming here'. ${ }^{52}$ Mary went on to describe his methods as follows: 'His theory is, that arthritis is caused by a nerve muscle in the foot being out of place, $\&$ by twisting the foot with his hand, he gets the nerve back into place. He has made a great name for himself because of his wonderful cures. ${ }^{53}$ Upon arrival at Williamsburg, they encountered a scene which William later likened to 'the maimed going to Christ'. ${ }^{54}$ Entering the street they found the street crowded with cars and patients with wheelchairs: 'And in an open space crowded with people $-\&$ a double queue of invalids in wheel chairs, was Dr Locke - in his shirtsleeves - giving treatments'. ${ }^{55}$ But William received no benefit from the treatment and the siblings instead resolved to 'put our faith in Dr Burbank. ${ }^{56}$

Government business intervened, however, and they managed only a brief visit to New York - long enough only to collect a case of fresh vaccines from Dr Burbank before their departure for London. ${ }^{57}$ There William had an audience with the King and briefly gained international fame as the government minister 'carried into [Buckingham] Palace in a chair. ${ }^{58}$ The conclusion of their trip in 1932 marked the end of William's search for health. William and Mary embarked on no further journeys in search of a cure, nor did William submit himself to any further experimental treatments. A letter of Mary's of the same year suggests that by 1932, William had come to accept his condition as intractable. She wrote to their sister Rachel: 'I think Willie realises he will never be able to walk. He is a brave little fellow \& says he has such a happy life that even with his handicap he cannot find time enough to give to all his interests - He says people all are very kind to him \& he finds life most interesting. ${ }^{59}$ In 1933, William again returned to the headlines when he resigned as Minister of Finance in protest at his government's

\footnotetext{
51 Mary to Rachel, 31 July 1932, MS-0985-040/012, HL.

52 Mary to Emily Gilbertson, 11 August 1932, MS-0985-051/022, HL.

53 Ibid.

54 Mary to Rachel, 7 August 1932, MS-0985-040/012, HL.

55 Mary to Emily Gilbertson, 11 August 1932, MS-0985-051/022, HL.

56 Ibid.

57 A famous doctor cousin of the Stewarts' friend Helen Rolleston - Sir Humphrey Rolleston - agreed to examine William but 'when he found Willie had seen Dr Burbank so recently \& had had a fresh vaccine made - he said he could not improve on that'. Mary to Rachel, 26 September 1932, MS-0985-040/012, HL.

58 'Received by the King,' Sydney Morning Herald, 8 October 1932, 14.

${ }_{59}$ Mary to Rachel, 19 September 1932, MS-0985-040/011, HL.
} 
decision to artificially devalue the New Zealand currency. ${ }^{60}$ He remained in Parliament until losing his seat in the 1935 election - a landslide win to the first Labour government - and devoted his retirement from politics to his other significant interest: the writing of New Zealand history and biography.

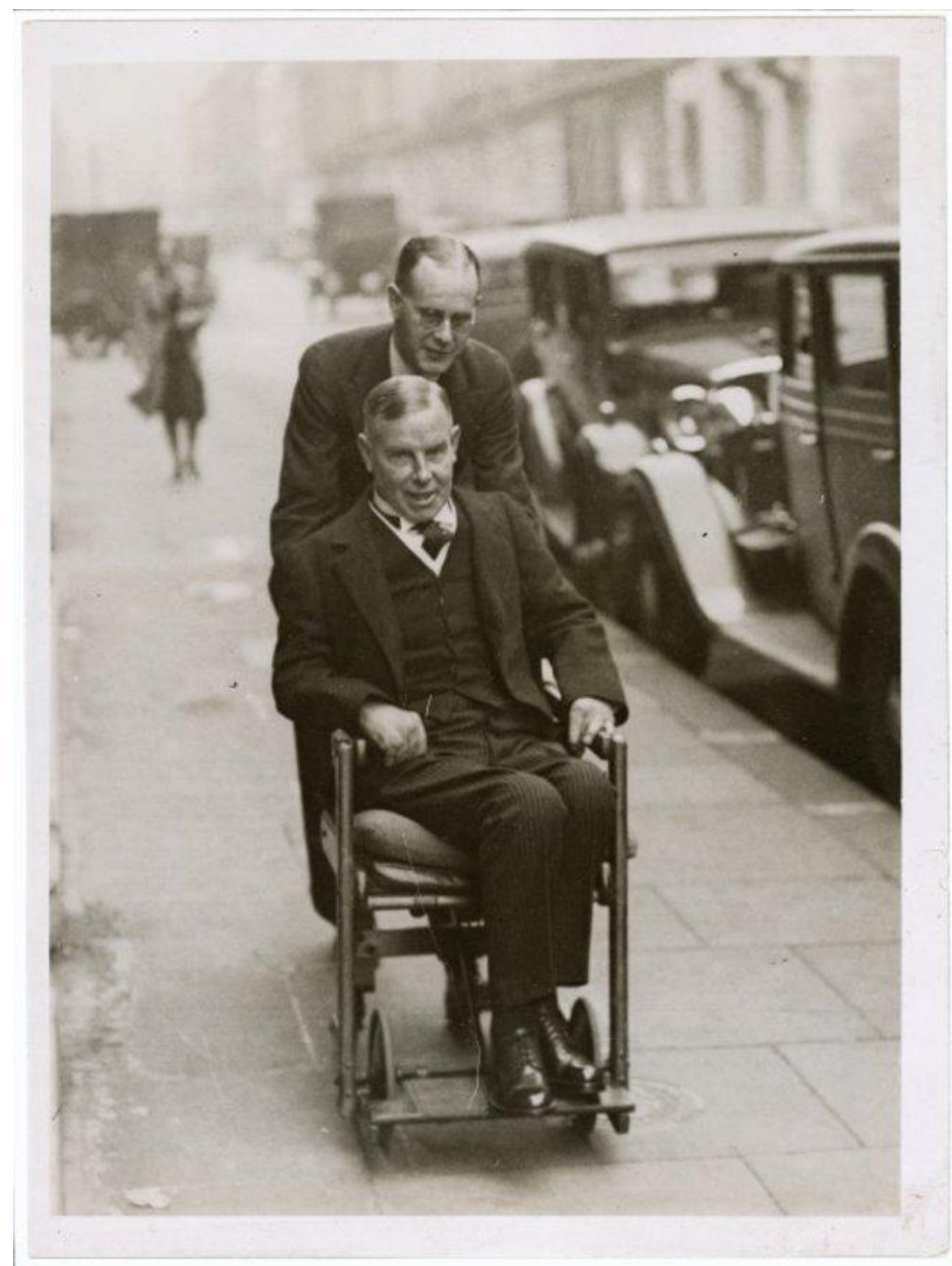

Figure 6.5: William Downie Stewart and nephew William Stewart Armitage, London, 1932

Source: PAColl-7081-59, ATL, http://natlib.govt.nz/records/22326843, accessed 29 March 2014.

${ }^{60}$ Dale, 'Stewart, William Downie - Biography'. 


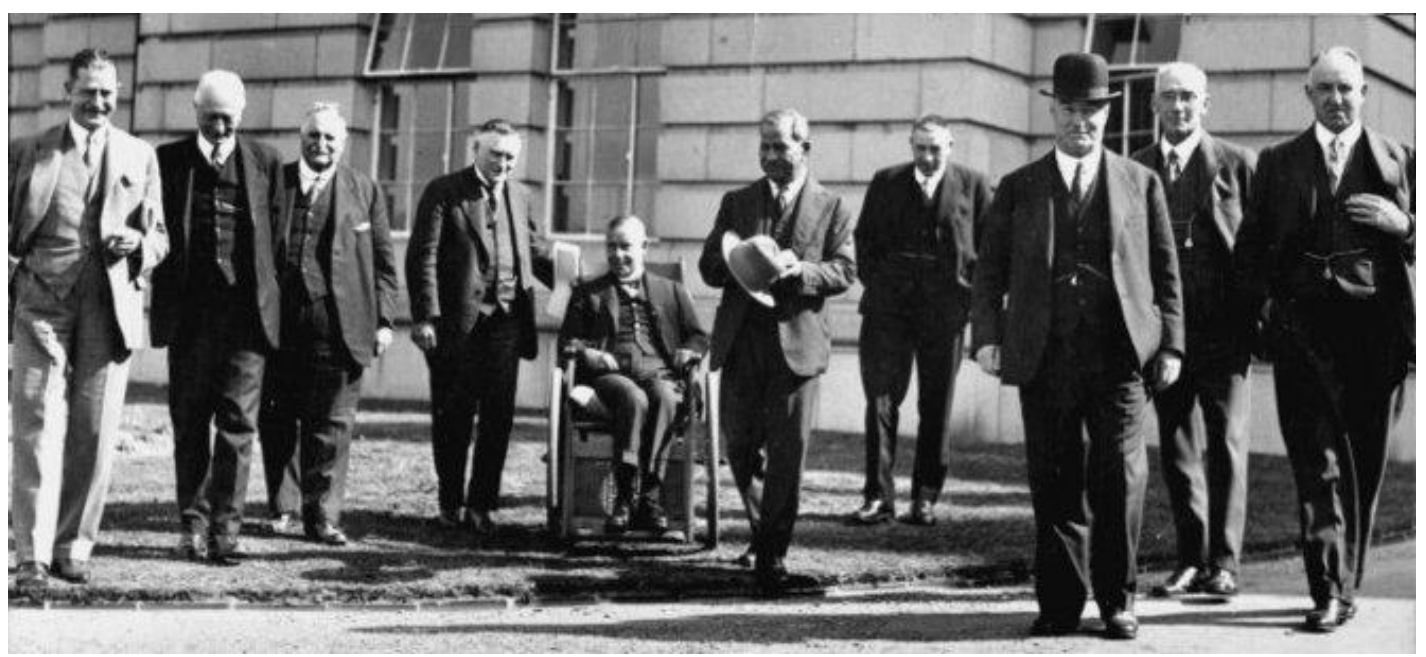

Figure 6.6: Cabinet Ministers of 1932

Source: PAColl-5469-041, ATL, http://natlib.govt.nz/records/22898447, accessed 29 March 2014. ${ }^{61}$

\section{A family disability.}

William's return home to New Zealand in 1916 transformed his relationship with his two surviving siblings. During his better periods, William was able to move about with the aid of crutches, to hold a book and use a pen. During times when his symptoms were at their most severe, however, he was reliant on others to read and write for him, to get him up in the morning and put him to bed at night, help him with bathing and toileting, and to cut his food and feed him. These tasks were performed mainly by Mary with the assistance of the family's domestic servants. ${ }^{62}$ During this time, William's physical symptoms and general health became a major preoccupation for both his sisters. At times when his symptoms were particularly acute, Mary monitored her brother's bodily functions - including his weight, diet, and digestive health - on a daily basis, duly conveying her observations in her regular letters to Rachel. Writing from New York in May 1926 Mary reported that William had been 'really seedy': 'His tummy was upset, his denture was hurting ... \& his weight went down 2lbs between Tuesday \& Friday' while walking was 'almost impossible'. ${ }^{63}$ In a letter the next month she wrote: Willie is much thinner but I got some sugar of milk to try \& fatten him - advised by Dr

\footnotetext{
${ }^{61}$ From left to right: Gordon Coates, John Cobbe, Charles Macmillan, James Young, William Downie Stewart, Apirana Ngata, Adam Hamilton, George Forbes, Sir Alfred Ransom and Robert Masters.

${ }^{62}$ Upon his return to Parliament in 1920, William was assigned a young returned soldier as messenger and attendant to wheel him to and from Parliament and look after him in the House. Mary to Rachel, c. 1920, MS-0985-040/007, HL.

${ }^{63}$ Mary to Rachel, 25 May 1925, MS-0985-040/010, HL.
} 
Burbank ${ }^{96}{ }^{64}$ In periods of ill-health, Mary slept in the same room as her brother. Writing after their return to New Zealand following their 1925 New York trip, Mary informed Rachel 'I have a stretcher brought in to his room at night, in fact, I have not left him at night since we left New York'. ${ }^{65}$ This arrangement continued until at least November 1925. In a letter that month, Mary informed Rachel that she had altered their usual sleeping arrangements, [s]ince my cold has been making my throat croaky - I have slept in my own room, not to disturb him - but he can always call through the wall' ${ }^{66}$ This constant surveillance and attendance to every aspect of William's bodily functions echoes the findings of other scholars on the way that disability served to 'infantilise' disabled men. ${ }^{67}$

Another way in which William's disability rendered him child-like in the eyes of those around him is seen in the efforts of his family members and doctors to shield him from medical knowledge surrounding his own condition. During their search for health, Mary took every possible opportunity to grill William's doctors for information while out of William's earshot. In a reversal of present-day expectations surrounding doctorpatient confidentiality, William's family members and doctors conspired to withhold information from their patient, and it is likely that of all his immediate family, William was the least informed about his own condition. ${ }^{68}$ After one such confidential conversation, in which Burbank had warned Mary that William would 'never walk as you and I can walk' and that it would be a year before he could walk without the assistance of crutches, Mary commented that the news was a shock as it conflicted with the picture of his condition that William had been receiving from the doctor: 'I felt my house of cards falling round me - because it seemed so different from the reports Willie has been getting. ${ }^{69}$ As well as shielding her brother from any potentially disheartening medical information about his condition, Mary also sought to protect him from her own increasing doubts surrounding his prospects for a cure. When, several months into their

${ }^{64}$ Mary to Rachel, 17 June 1925, MS-0985-040/010, HL.

${ }_{65}$ Mary to Rachel, 17 July 1925, MS-0985-040/010, HL.

${ }^{66}$ Mary to Rachel, 19 November 1925, MS-0985-040/010, HL. While some close sibling relationships have been linked with incest, Mary's descriptions of her relationship with William are more evocative of a maternal than sexual relationship. 'Willie is snuggled up in bed like a little rabbit', Mary reported to Rachel in one January 1918 letter. Mary to Rachel, 6 January 1918, MS-0985-040/004, HL.

${ }^{67}$ Koven, 'Remembering and Dismemberment'.

${ }^{68}$ Letters in the Stewart family correspondence suggest that it was common practice in this period for even terminally-ill patients to not be appraised of their prognosis. When the Stewart's cousin Stewart Bartleman wrote to William in 1916 with news of her dying mother she reported: 'A tranquil body \& a tranquil mind are absolutely necessary \& she is not to do anything at all except take a "Rachael" bath at night. ... The diagnosis came as a shock to me but of course Mother must not know anything about it'. B. Stewart Bartleman to William, 26 January 1916, MS0985-003/013, HL.

${ }^{69}$ Mary to Rachel, 4 June 1925, MS-0985-040/010, HL. 
1925 trip to New York, Mary confessed to Rachel that: 'the whole thing has been a terrific strain \& I dread a failure' she warned: 'Please don't refer to it too much - when writing - as I always read your letters aloud to him, \& I never let him think I have any doubt at all about his ultimate recovery'. ${ }^{70}$

In 1920, while dining at the home of parliamentary friends the Kennedys, Mary received some troubling news about the origins of her brother William's illness. At the dinner party, Mary met Dr Wilson, son-in-law to their hosts. As she later related to Rachel, the doctor 'took my breath away by saying, "Do you know he had arthritis before he went away." I asked him what made him say such a thing $-\&$ he said he had been looking at a photo in Mr Kennedy's room, and his hands have distinct signs of it. I felt myself getting quite sick, \& said he must be mistaken. But he is certain \& the war hastened it on'. ${ }^{71}$ Mary immediately resolved not to disclose this news to William, informing Rachel: 'I have not told Willie \& I think it wiser he should not know for many reasons.$^{72}$ Mary's distress partly arose from her belief that an illness of longer duration would have become more entrenched: 'I said to Dr Wilson: “Then, if this is so, it means it will be much more difficult to cure, than if it was brought on more recently by the war". He said he did not want to worry me'. ${ }^{73}$ But her response is also suggestive of her own investment in the notion of William's illness as a 'war sacrifice': 'I have not told about Willie - as I am trying to argue to myself that if he had not gone to the war - this may not have developed for years, the doctor said. So that after all - he wld find some comfort in the knowledge that it was the war that brought it on \& it is part of his sacrifice to his country. ${ }^{74}$ Thus, it is likely that William never learned of this varying medical assessment of his illness's origins.

\section{Gender and duty after the war}

As many accounts of disabled soldiers emphasise, disabled soldiers' duty did not end after illness or wounds rendered them unfit for further service, but continued throughout their treatment, rehabilitation and return to civilian society. The first duty of disabled soldiers was to maintain an optimistic frame of mind about their present condition and future prospects. William's letters to his family members on the subject of

\footnotetext{
70 Mary to Rachel, 25 May 1925, MS-0985-040/010, HL.

71 Mary to Rachel, 1920, MS-0985-040/007, HL.

72 Ibid.

73 Ibid.

74 Ibid.
} 
his illness invariably express optimism that his condition could be successfully cured. While observing in April 1917 that fellow arthritis sufferer and Rotorua patient Major Taylor 'did not seem to me much better for his 3 months here - nor has he much faith in his treatment', and that 'certainly there seem to be an immense number of cripples about here who do not show any improvement after months of treatment' William continued to express faith in his own recovery: 'I am still full of optimism \& confidence that all will come right. ${ }^{, 75}$ This emphasis on positivity stemmed partly from William's belief that negativity itself could hinder his recovery. 'I don't find myself worrying nearly so much as my friends as to making progress in health \& if I did worry no doubt it would retard me ${ }^{76}$ Such outward displays of positivity - what accounts of hospitalised First World War soldiers termed 'cheerfulness' - were crucial to the sickbed performance of male invalids in this era. As Janet Oppenheim writes, late Victorian and Edwardian men learned the "paramount necessity for self-control in every aspect of their character' and, as such, despondency, nervous breakdown or depression was widely regarded as a 'failure of the will' and a 'display of weakness' that was 'virtually unforgivable'. ${ }^{77}$ A patient's display of 'cheerfulness' signalled to others the strength of his inner willpower and demonstrated that he had not succuumbed, in weakness, to selfpity and despair.

This essentially Victorian ideology of willpower formed a central component of the medical and rehabilitation programmes at Rotorua and other institutions for the treatment of disabled First World War soldiers. ${ }^{78}$ From 1918, the Rehabilitation Department replaced the Discharged Soldiers' Information Department as the government agency responsible for the treatment and rehabilitation of disabled soldiers upon their return to New Zealand. A 1919 booklet publicising the Department's work claimed that in the case of many soldier patients it encountered: 'the soldiers' trouble' turned out to be 'due rather to a mental attitude than to real functional disability'. For these individuals, the cure rested not in conventional medical treatment but in creating an environment conducive to the psychological well-being of patients and the restoration of the willpower: 'It is recognized that every possible care has to be taken to keep the men in the best possible state of mind to help their bodies. They are

\footnotetext{
75 William to Rachel, 7 April 1917, MS-0985-039/004, HL.

76 William to Rachel, c. 1917, MS-0985-039/004, HL.

77 Janet Oppenheim, Shattered Nerves: Doctors, Patients and Depression in Victorian England (New York: Oxford University Press, 1991), 43; 150-151.

78 Walker, 'The Living Death,' 64.
} 
encouraged to look outward brightly in hope, not inward darkly in despair. Always they are led to exercise of mind and body, but not worried about it. ${ }^{79}$ This emphasis on individual willpower was also a feature of rehabilitation programmes for disabled First World War soldiers elsewhere. Those in charge of disabled soldiers' rehabilitation in Australia, Larsson writes, hoped that 'each man could transcend his impairments through determination and will-power, thereby regaining "captaincy of the soul". 80

The ultimate goal of medical and rehabilitation programmes targetted at disabled soldiers was to return men as quickly as possible to employment. Disabled soldiers' rehabilitation was thus inextricably connected with the masculine ideals of the breadwinner and provider. ${ }^{81}$ In New Zealand as elsewhere, 'work' was central to efforts to treat and rehabilitate disabled veterans. In the British context, Seth Koven writes, '[p]hysically, work was occupational therapy to unlock and develop bodily powers; economically it was thought to promise cripples financial independence; morally, it promoted the self-help essential to combat self-pity' ${ }^{82}$ William Downie Stewart, in a 1919 interview on the government's rehabilitation programmes, underscored the centrality of 'work' as a 'mental tonic' to aid soldiers in their recovery. 'There are many thousands of men who could have been materially helped in their recovery of health and in their future employment had proper workshops been established in the centres of treatment soon after invalided men began to come back." ${ }^{83}$ 'Many of these men,' he went on, 'would be greatly helped in their recovery if their future employment had already been discussed with them ... In going around the wards at Rotorua he had met numbers of soldiers who were very depressed through uncertainty as to their future, and the mental tonic which resulted from this uncertainty being removed would be an enormous aid to their recovery. ${ }^{84}$

While disabled mens' duty was to recover their health and return to the workforce as soon as possible, the obligations of their female relatives were conceived

\footnotetext{
${ }^{79}$ L. S. Fanning, ed., Winning Through From War to Peace: New Zealand (Wellington: Govt. Printer, 1919), 4. Available from: http://christchurchcitylibraries.com/DigitalCollection/WarsandConflicts/WorldWarI/WinningThrough1919/, accessed 13 March 2014; Walker, 'The Living Death', 64-66.

${ }^{80}$ Marina Larsson, 'Restoring the Spirit: The Rehabilitation of Disabled Soldiers in Australia after the Great War,' Health and History 6, no. 2 (2004), 47.

81 Walker, 'The Living Death,' 123.

82 Koven, 'Remembering and Dismemberment', 1175. On First World War veterans and work therapy see also Jeffrey Reznick, 'Work-Therapy and the Disabled British Soldier in Great Britain in the First World War: The Case of Shepherd's Bush Military Hospital, London,' in Disabled Veterans in History, ed., David Gerber (Ann Arbor: University of Michigan Press, 2000), 185-203.

83 'Repatriation', Otago Daily Times, 18 January 1919, 5.

${ }^{84}$ Ibid.
} 
of in markedly different ways. Women's first duty after the war, as described by J. C. McLeod, was that of giving up jobs for returning soldiers. ${ }^{85}$ Another socially acceptable form of women's duty was to devote their lives to caring for the disabled victims of war. Mary's 'sacrifice' in caring for William was referred to in several letters by friends and family from this period. Writing to Mary in 1921 of her pride at seeing William 'steering the affairs of parliament for our country' Johanna Fraser, former Crookston postmistress, acknowledged Mary's own 'arduous task of getting $\mathrm{Mr}$ Stewart to represent us. ${ }^{96}$ She went on: 'There is a deal said and written now-a-days about service for others... What a bright example you and your brothers give of that self-sacrifice and world service! ${ }^{87}$ Similarly, a distant cousin praised Mary in 1928 for her life of 'selfsacrifice \& service' in caring for her brother: 'I should like you to know that this is the finest interpretation of the word "Service" I have yet found...many people lay down their lives for their friends by a continuous giving of themselves for others, and surely this is as fine a sacrifice, perhaps finer, as one final, supreme sacrifice made in yielding up mortality itself. ${ }^{88}$

We need not view Mary and William's relationship in the same polarised terms of altruism or selfishness as some of their contemporaries did. By the time of William's return from the war in 1916, Mary - then aged 40 - appears to have been considered beyond marriageable age. The same was not the case for William, two years her junior. During the 1920s, William pursued several love affairs with a view to his marriage. The prospect of William marrying was initially greeted positively by his sister-in-law Elizabeth. Her comments point to a further possibility for women's wartime service highlighted by commentators during the war and in the immediate postwar period: the emotional labour of marrying a disabled soldier to nurse back to health. ${ }^{89}$ From Elizabeth's perspective, William's disability did not present an obstacle to his future marriage 'for the infirmities of the body carry little weight in the affairs of the soul'.90 Moreover, the right woman 'would glory helping to carry his burden $\&$ in making up to him in ways that matter more - for what he was missing in more material things'. ${ }^{91}$

${ }^{85}$ McLeod, 'Activities of New Zealand Women,' 114-117.

${ }^{86}$ Johanna Fraser to Mary, 16 December 1921, MB-391-1/5, MBL.

${ }^{87} \mathrm{Ibid}$.

88 'Cousin Bob' to Mary, 19 November 1928, MS-0985-051/021, HL.

${ }^{89}$ During the war, an English clergyman established an agency to procure wives for disabled soldiers who, according to the agency's publicity, would 'give back to "wounded heroes" their manliness and save themselves from an "unwholesome" and selfish single life'. Koven, 'Remembering and Dismemberment,' 1189.

${ }^{90}$ Elizabeth to Rachel, c. 1918, MB-391-4/26, MBL.

${ }^{91}$ Ibid. 
The most serious of William's romantic relationships was with Mrs Eila Williams, nee Vallance, a war widow with young children. Mary proved openly hostile to this, and all others of her brother's romantic liaisons. ${ }^{92}$ Her frostiness towards Williams was probably a factor in Eila's decision to leave Dunedin to spend a year at her parents home in Masterton, a move which effectively spelled the end of her relationship with William. ${ }^{93}$ However, while Mary's hostility certainly contributed to the souring of the relationship, William's own complacency in pursuing the affair was probably also a factor. ${ }^{94}$ This was acknowledged by Elizabeth in a 1922 letter, in which she confessed to having experienced a change of heart about 'Downie's affair': 'Downie is too deeply engrossed in his books \& his parliamentary life to give to a woman what any woman who married for love, would rightly expect - In less than no time she would be heart hungry, \& that would spell disaster for both of them - only the woman would suffer far more keenly. ${ }^{95}$ In his sister Mary, William gained a source of care and companionship without the emotional demands of a wife. Likewise, while William's care absorbed much of Mary's time and strength, it also gave her a sense of life purpose and a positive identity centred in family relationships alternative to that of mother and wife. Writing to Tom Seddon and his wife after William's death in 1949 Mary wrote of her gratitude that 'I, so stupid \& unintellectual should have been chosen to take care of him \& share his life. That is something to be terribly proud of \& thankful for - because we fitted in so wonderfully $\&$ were so happy $\&$ he never made me feel I was a fool. ${ }^{96}$

\footnotetext{
92 Mary had been similarly hostile towards a Miss Austin, a Sydney woman who she suspected of having romantic designs on William. Mary wrote to Rachel: 'The nurses told me today that they notice as soon as my back is turned Miss Austin arrives to see him but I told them I can't pitch a tent at the door just to play the dragon'. Besides, she added 'she is as old as Miss Susie Webster' and a Catholic: 'I want him to marry when he is well again - but he must marry a protestant'. Mary to Rachel, MS-0985-040/004, HL.

93 While ostensibly for financial reasons and her son's health, Eila told William she couldn't "sit on a farce" any longer \& she thinks it might look like trying to force my hand if she stays near'. William to Rachel, 30 January 1922, MS-0985-039/004, HL. While William took this statement at face value, it is tempting to speculate that this announcement might have been a ploy to force William's hand in the other direction - in the way of the 'test of devotion' common in Victorian courtship rituals. See Lystra, Searching the Heart, chapter 6.

94 William wrote to Rachel upon Eila Williams' departure: 'probably you will welcome the 12 months absence as likely to lead to an end of my adventure. Perhaps so! If so so be it. I am too busy to do other than live from day to day \& let destiny weave whatever web it may.' William to Rachel, 14 January 1922, MS-0985-039/004, HL.

${ }^{95}$ Elizabeth to Rachel, 22 February 1922, MB-391-32/265, MBL.

${ }_{96}^{6}$ Mary to Mr and Mrs T E Y Seddon, 4 December 1949, Folder 155, MS-Papers-1619, ATL.
} 


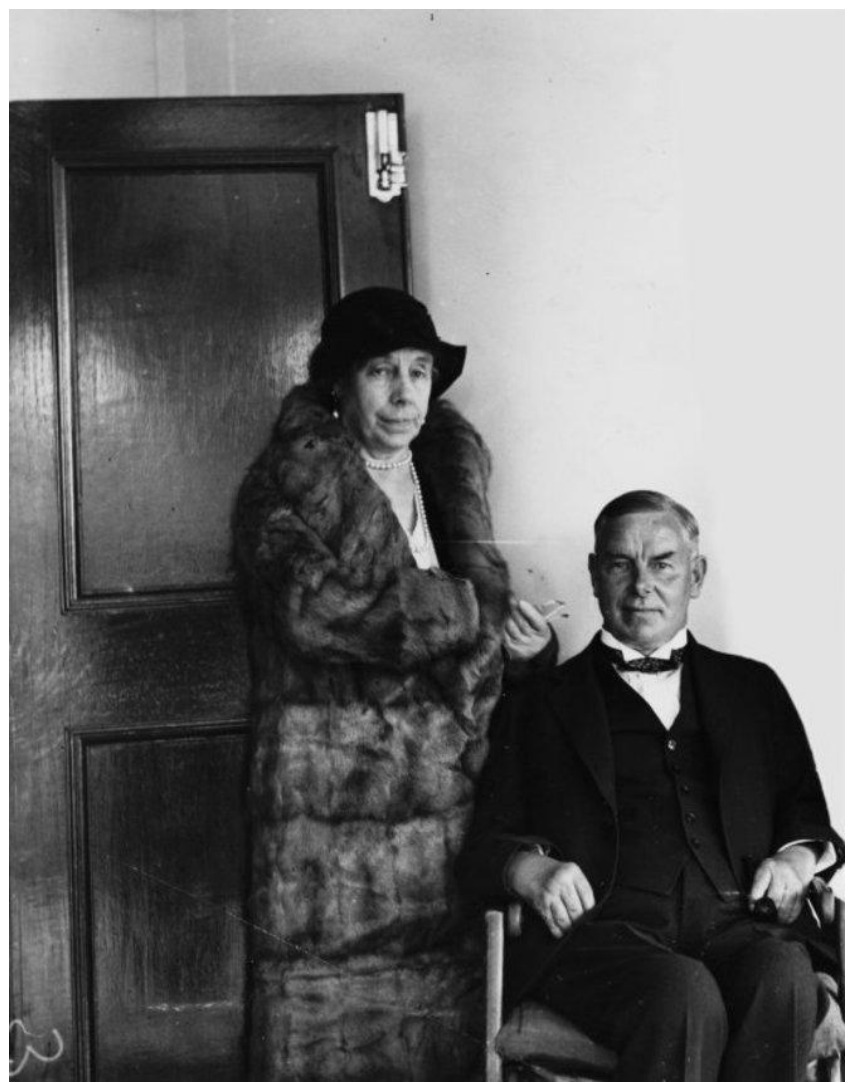

Figure 6.7: William and Mary Downie Stewart, c. 1941

Source: PA-Coll-6301-31, ATL, http://natlib.govt.nz/records/22341700, accessed 29 March 2014.

\section{Disability in the public sphere.}

The latter years of the nineteenth and early years of the twentieth century coincided with the rise of masculine ideals concerned with 'robust physique' and 'sporting manliness'. ${ }^{97}$ Even before his departure for war, William Downie Stewart bore little semblance to such ideals. Bookish and slight of build, he was accustomed to a sedentary lifestyle spent indoors, engaged in intellectual pursuits. His rendition as 'Wee Downie Stewart' in political satire before the war referenced not only his Scottish ethnicity, but his diminutive stature. ${ }^{98}$ His friend and fellow enlistee Thomas Seddon later described him as 'never robust' and unaccustomed to the 'rough life..${ }^{99}$ It is telling of the powerful connection between masculinity and physical prowess in this period that, in at least one account of his enlistment, simply signing up for the army was productive of changes to his physique. 'Two such capable men with athletic records are bound to win their way

\footnotetext{
${ }^{97}$ Oppenheim, Shattered Nerves, 148; Frawley, Invalidism and Identity, 89.

${ }^{98}$ See for example 'Tangled Talk,' NZ Truth, 25 April 1914, 3.

${ }^{99}$ Seddon, The Seddons, 240-241.
} 
up', the national pictorial paper the Free Lance editorialised upon the two men's enlistment. ${ }^{100}$

Camp life effected further improvements to the two men's physical appearance. When William and Seddon attended parliament in uniform in August 1915 a local newspaper described both politicians as 'much improved physically': 'They have followed the custom of many soldiers on active service by growing moustaches, and in appearance they are bronzed and bear evident signs of the spell of active outdoor life'. ${ }^{101}$ Certainly, William himself enjoyed the vigorous physical regime of camp life and its contrast from his former lifestyle, writing to his brother George from Tauherenikau: 'I am still enjoying the military life tremendously $\&$ feel very fit, eat like a horse, \& have no worries' ${ }^{102}$ Early in January 1916, William and Seddon joined the 'athletic-looking' ninth division in their march through Wellington on the eve of their departure for the front, one newspaper report of proceedings of the day exclaiming of the division: 'how fit they were! Fit, indeed, to fight for an Empire!' ${ }^{103}$

During the general election of 1919 the social divisions of the war years remained fresh in the minds of politicians and the public. Candidates' earlier stance upon the war came to occupy a key role in electioneering. ${ }^{104}$ In the lead up to the 1919 election the Reform Party sought to label its Labour Party rivals as unpatriotic due to their earlier opposition to conscription and championing of the cause of conscientious objectors. ${ }^{105}$ An advertisement placed in the Otago Daily Times in December 1919 asked Dunedin voters: 'Are you going to vote for the man who rendered no service to your country and the Digger, when that service was most wanted. Are you going to vote for the man who perpetually championed the cause of the shirker, while your Digger was fighting for King and Country and the shirker? ${ }^{306}$ In the event, Labour actually gained

\footnotetext{
100 The article went on to describe in detail Tom Seddon's 'long and good' athletic record, but provided no further evidence of William's supposed athletic prowess. 'All Sorts of People,' Free Lance, 18 June 1915, 4.

101 'Soldier Legislators,' Wanganui Chronicle, 25 August 1915, 5.

102 William to George, 26 November 1915, MS-0985-044/002, HL. After seeing her brother-in-law in Egypt,

Elizabeth Stewart reported that he was looking 'better than I have ever known him to look since first I knew him Of course he is as slight as ever but his face is fuller \& brown \& healthy looking \& he is in good form'. Elizabeth to Mary and Rachel, 1 March 1916, MS-0985-041/002, HL.

103 'The Khaki Line,' Dominion, 10 January 1916, 6.

104 The RSA lobbied its members to support returned soldier candidates of all parties. Stephen Clarke, 'Return, Repatriation, Remembrance and the Returned Soldiers' Association 1916-22, in New Zealand's Great War, eds., Crawford and McGibbon, 165-166.

105 For Labour's position on the war see Gustafson, Labour's Path to Political Independence, chapter 10.

106 'The General Election,' Otago Daily Times, 9 December 1919, 4. Similar rhetoric was used by conservative MPs in Britain. See Richard Carr, 'Conservative Veteran M.P.s and the 'Lost Generation' Narrative After the First World War,' Historical Research 85, issue 228 (May 2012): 14.
} 
ground among working-class constituents in the 1919 election due to the government's failure to stem the rising cost of living. ${ }^{107}$ Nevertheless, the Reform party attempted to capitalise upon its MPs' wartime service as late as 1926 when it published advertisements depicting then-Prime Minister Coates 'going over the top to fight the forces represented by Labour'. ${ }^{108}$

Some voters were certainly swayed by such arguments. In Dunedin, in 1919, 'Working Man' informed the editor of the Otago Daily Times of his decision to reject his local labour candidate on the basis of Labour's stance toward the war: 'I myself am only a working man, but, with my returned boys, will vote for Mr Downie Stewart, who did his duty'. ${ }^{109}$ Around this time William's political opponents began to circulate rumours that he had not reached the front lines. Spiers, the Stewart's gardener, was reputed to have 'nearly knocked a man down for saying W. had not gone to France or some such. ${ }^{110}$ By early December, these rumours had gained such traction that William's commanding officer Colonel D. Colquhoun, himself a candidate for political office in the election, found it necessary to refute the allegations through an article placed in local newspapers. ${ }^{111}$

Meanwhile, Mary stage-managed her brother's public appearances so as to minimise the visibility of his disability. ${ }^{112}$ Prior to one of William's election appearances in 1919, Mary suggested 'he shd go $1 / 2$ an hour early \& be sitting on the platform chatting informally with a few men until the hall fills \& need not walk at all while people are looking. Dr Fitchett suggests sitting in his chair before the curtain goes up but of course in most small halls there is no curtain'. ${ }^{113}$ Similarly, in the lead-up to the 1925 election, Mary prepared the stage in advance of one of her brother's public appearances by moving 'shrubs etc along the front to hide his entrance a little \& put the table near the door $\&$ his chair nearer still, so all he had to do was walk about 6 steps'. ${ }^{114}$

\footnotetext{
107 Michael Bassett, The State in New Zealand 1840-1984. Socialism Without Doctrines? (Auckland: Auckland University Press, 1998), 146.

108 The Reform advertisement created controversy in Parliament, including from John A. Lee. The Auckland Star reported the debate as follows: 'In the party led by Mr. Coates there was only one returned soldier, while in the Labour party there were two, Mr Lee concluded, as he turned over a pile of papers with the stump of his left arm, which he lost at the war'. 'Parliamentary Gossip,' Auckland Star, 30 June 1926, 12.

109 'The Labour Candidates,' Otago Daily Times, 9 December 1919, 8.

110 Mary to Rachel, c. 1919, MS-0985-040/006, HL.

111 'A Malicious Rumour,' Otago Daily Times, 6 December 1919, 4. Captain Colquhoun ran for the Liberals in the Port Chalmers electorate but was defeated by Reform candidate James Dickson.

112 See also Robertson, 'A Victorian Lady,' 63.

113 Mary to Rachel, c. 1919, MS-0985-040/006, HL.

${ }^{114}$ Mary to Rachel, 25 June 1925, MS-0985-040/010, HL.
} 
William was among four MPs who returned from the war and resumed seats in Parliament. ${ }^{115}$ They were joined after the 1919 general election by George Mitchell, a returned soldier and Wellington Returned Services Association (RSA) president. Clutha Mackenzie, blinded soldier and Reform candidate, lost his bid for election in 1919, but won a 1921 by-election. He lost his Auckland East seat to another disabled returned soldier, John A. Lee, in the general election the following year. ${ }^{116}$ In 1922, nine veterans won Parliamentary seats. ${ }^{117}$ Despite the RSA's lament in the wake of that election that the 'war has been forgotten' by voters, the youthfulness of the returned soldier population was a more likely explanation for the relatively low numbers of ex-soldiers in Parliament in the early 1920s. ${ }^{118}$ Their numbers continued to increase over the interwar decades, with one newspaper noting in 1936 that 'the present parliament includes more ex-soldiers than ever before in the history of New Zealand'. ${ }^{119}$

The veteran MPs in the House in the 1920s included a number of severely disabled men. In addition to William Downie Stewart, there were Clutha Mackenzie, blinded in both eyes by an exploding shell at Gallipoli, and John A Lee, who lost an arm to amputation following a gunshot wound received at Messines in $1917 .{ }^{120}$ All three men were consistently described by public commentators in embodied terms - with their bodily afflictions tied to, and ascribed meaning in terms of, their earlier war service. William's physical frailty, explained the Evening Post in 1921, was no mere illness but 'the penalty he is still paying for his faithful service in another sphere during the war'. ${ }^{121}$ William would 'carry the marks of the war to his grave' one of his parliamentary colleagues claimed in 1919. ${ }^{122}$ For the Weekly Press, Lee's '[e]mpty coat sleeve' was 'not the only symbol of the born fighter the Member for Auckland East is unable to hide or disguise. He carries his military dash and impetuosity into the political arena as if there were still machine guns to be captured single handed and Mailly Maillets to be

\footnotetext{
115 The four MPs were J. G. Coates, J. B. Hine, T. E. Y Seddon and William Downie Stewart. Clarke, 'Return, Repatriation, Remembrance,' 166.

116 Clarke, 'Return, Repatriation, Remembrance,' 166.

117 J. G. Coates, Allan Bell, John A Lee, V. H. Potter, W. J. Jordan, J. C. Rolleston, W. S. Glenn, and William Downie Stewart. Quick March, 10 January 1923, 21.

118 Quick March, 10 January 1923, 21.

119 'Soldier Members,' Auckland Star, 14 February 1936, 3. The 1936 Parliament included 20 soldiers in the House and three in the Legislative Council.

120 Penelope Hansen, 'Mackenzie, Clutha Nantes - Biography,' DNZB, updated 12-Nov-2013, URL:

http://www.TeAra.govt.nz/en/biographies/4m17/mackenzie-clutha-nantes, accessed 13 March 2014; Erik Olssen, John A. Lee (Dunedin: University of Otago Press, 1977).

121 'Cabinet Changes,' Evening Post, 23 February 1921, 6.

122 'Contemptible Action,' Otago Daily Times, 5 September 1919, 6. The speaker was Leonard Isitt.
} 
stormed'. ${ }^{123}$ Even non-disabled returned soldier MPs were portrayed using militarised language. In 1925 then-Premier Gordon Coates was described by a London newspaper as 'a tall, lithe man, erect and soldierly in figure, whose body, compact of bone and muscle, is a stranger to fatigue.' ${ }^{124}$

Lee's missing arm and Mackenzie's blindness could be described as heroic scars of war with little explanation. The same was not so in William's case. Most newspaper articles accepted the link between the onset of William's disability and the war without question. A 1925 NZ Truth piece on William Downie Stewart which opened memorably with the line 'Frail of frame, but big of brain' claimed that: 'While away doing his bit towards stilling the world convulsion caused by Germany, he was crippled by a disease that seized and held him in its vicious grip, but he came back from his recent healthseeking trip to America full of cheerfulness and optimism, and if the wishes of his battalions of friends count for anything, he will soon be bustling about again'. ${ }^{25}$ William Downie Stewart, explained the Marlborough Express, had 'returned a wreck from the war'. ${ }^{126}$ The Auckland Star's attribution of William's impairment to 'war injuries' displayed a confusion surrounding the events leading up to William's illness also evident in other accounts. ${ }^{127}$

But other newspaper reports attempted to more precisely link the onset of William's illness to the conditions of war. William's 1916 diagnosis of 'trench fever' provided one explanation for his medical condition that plausibly linked it with his time in the trenches. Lieutenant Downie Stewart had, a 1916 Evening Post article explained, been 'seized with an attack of rheumatoid arthritis, a severe rheumatic complaint commonly known as "trench fever". ${ }^{128}$ The Free Lance's account also explained William's illness as due to the conditions of trench warfare, while exhibiting a degree of creative license in describing the details of his military service. William's enfeebled state was: 'a pathetic reminder of the sacrifices that war entails...The rheumatism that he contracted by exposure to cold and wet in the wintry trenches of Flanders while he was "doing his bit" for King and country was painfully evident in his contracted

\footnotetext{
123 The Weekly Press, 26 August 1926; cited in Olssen, John A. Lee, 43.

124 Daily Mail, cited in Bassett, Coates of Kaipara, 99.

125 'Downie Stewart,' NZ Truth, 10 October 1925, 6.

126 'Parliament,' Marlborough Express, 25 October 1918, 7.

127 'Parliament's Opening,' Auckland Star, 25 October 1918, 4. See also 'Sir William Herries,' Northern Advocate, 1 February 1921, 2.

128 'Soldier M.P. Returns,' Evening Post, 20 December 1916, 3. See also Auckland Star, 20 December 1916, 7.
} 
figure... That terrible winter of 1915 that he spent at the fighting front has stiffed all the supple joints and racked the still youthful body with rheumatism'. ${ }^{129}$

Colquhoun's 1919 letter confirming the details of William's military service provided an explanation for the onset of his illness that echoed the claims of nineteenth-century male invalids to have arrived at their conditions through 'overwork', or as Koven has termed it, through 'an excess of doing what it was to be a man'. ${ }^{130}$ William's present affliction, Colquhoun explained, was due to the fact that William had, out of his desire to serve his country, delayed seeking treatment for so long: 'It was on account of his devotion to duty, and because he hung on too long that he is suffering the great disadvantage of bad health to-day,. ${ }^{131}$ This suggested that William's physical impairment had come about through his possession of a surplus of manly duty.

Despite the consistently embodied ways in which soldier MPs were depicted, not all accounts of William's disability tied manly qualities to physical attributes. Some articles linked manly traits such as virility or strength to William's intellectual attributes. ${ }^{132}$ An article, which originally appeared in the Canadian Vancouver Daily Province, republished by the Evening Post, exemplifies this approach. Playing repeatedly on the contrast between William's physical weakness and mental strength, the article emphasised how William dominated his more physically-able political opponents on the floor of parliament through sheer intellectual mastery: 'In the Commons of New Zealand there is a man who does not even try to rise, but he is very effective in cutting the ground from the other fellow's feet'. ${ }^{133}$ The same journalist described William as 'a dynamo of energy suppressed. He can not leap to his feet as he was wont to do, but there is no lack of vigour in his speech'. ${ }^{134}$ Displaying a similar confusion to previous authors as to the events surrounding the onset of William's illness, the author went on to explain: 'He used to pound one palm with the other fist to emphasise his point, but since arthritis set in as an aftermath to his war wounds, his hands lie inert on the table. From the chin up, however, Downie Stewart is alert and compelling... Political faddists

\footnotetext{
129 'All Sorts of People', Free Lance, 31 October 1918, 4. Contrary to the Free Lance's claims, William's military service was entirely during the European spring and summer and he did not serve at Flanders.

130 Seth Koven, 'Prisoners of Their Beds: Invalids, Injured Soldiers, and Cultures of Convalescence in Nineteenthand Early-Twentieth-Century Britain,' Radical History Review 94 (Winter 2006): 235. See also Frawley, Invalidism and Identity, 45; Oppenheim, 142-3; 153.

131 'A Malicious Rumour,' Otago Daily Times, 6 December 1919, 4.

132 See Erik Olssen. 'Working Gender, Gendering Work,' 54.

133 Vancouver Daily Province, 25 July 1932, quoted in 'Mr. Downie Stewart. A Canadian Tribute,' Evening Post, 8 September 1932, 12.

${ }^{134}$ Ibid.
} 
have learned to dread the impact of his cold logic. He dominates the House from a wheelchair'. ${ }^{135}$ By way of a finishing flourish, the article's author credited William with the feat of having 'under[taken] a journey of 18,000 miles in a wheelchair'. ${ }^{136}$ Such contrasts between mental strength and physical weakness played on and reinforced popular perceptions that physical impairments were usually accompanied by mental weakness or laziness, as evidenced by the Auckland Star's observation that 'His power of mental concentration seems never to have been impaired by his severe physical disability. ${ }^{137}$

Aside from providing bodily reminders of veteran MPs' earlier war service, the predominant message contained in descriptions of William Downie Stewart and his fellow disabled veteran MPs was proof of what even severely disabled men could achieve if they applied their willpower. Ana Carden-Coyle, writing of responses to disability in Anglo-phone countries after the war, describes narratives of 'overcoming' as 'the dominant social and medical response to disability' in these countries following the war. ${ }^{138}$ Writing of William's first Cabinet position in 1921, the Evening Post reported that: 'Mr Downie Stewart's success in spite of the great physical handicap to which we have referred is...a matter for special rejoicing. ${ }^{139} \mathrm{~J}$. H. Thomas, Secretary of State for the Dominions, speaking on the event of William's 1932 visit to London, paid tribute to William's 'mental conquest over physical martyrdom'. ${ }^{140}$ Even the radical labour paper the Maoriland Worker '[could not] help liking the man and added to that is the fact of his physical disabilities through the war. When you see a man carried into the House to attend to his work, you cannot help but admire the man'. ${ }^{141}$ Other disabled ex-soldier MPs were praised in similar terms. Clutha Mackenzie's career, one newspaper claimed in 1921, 'showed how a really badly disabled man could adapt himself to new work in his strangely altered life'. ${ }^{142}$ Narratives of overcoming shared in common with medical discourses surrounding the treatment and rehabilitation of returned soldiers the assumption that disability was as much attitudinal as physiological. 'Mr Mackenzie does

\footnotetext{
135 Ibid.

136 Ibid.

137 'The New Minister,' Auckland Star, 1 March 1921, 6.

138 Ana Carden-Coyne, Reconstructing the Body: Classicism, Modernism, and the First World War (Oxford: Oxford University Press, 2009), 61.

139 'Cabinet Changes,' Evening Post, 23 February 1921, 6.

140 'Ties of Kinship,' Auckland Star, 24 September 1932, 9.

141 'Notes to Henry,' Maoriland Worker, 9 March 1921, 6.

142 'The New Member,' Asbburton Guardian, 3 November 1921, 5.
} 
not allow his loss of sight to be a severe disability' stated the Northern Advocate, reporting upon Mackenzie's arrival to Parliament in $1921 .^{143}$

Narratives of 'overcoming' contained a potentially affirming message surrounding disability that some disabled men undoubtedly found empowering. Nevertheless, praise of soldier MPs' ability to overcome the obstacles of their disabilities and achieve success in their chosen careers overlooked the narrow applicability of their particular cases, while implicitly placing responsibility for soldiers' successful recovery and reintegration back into society back upon the individuals themselves. Disabled veterans had little choice but to take personal responsibility for their own rehabilitation after 1922, when the Rehabilitation Department was closed. ${ }^{144}$ Few disabled men could have possessed the ability and connections necessary to become a successful MP, and as advocates for disabled veterans recognised, most severely disabled men were excluded from all but a narrow range of occupations. ${ }^{145}$ As seen in chapter five, other war veterans suffering from illnesses prevalent in the civilian population were forced to prove their condition's attributability to war and could be denied access to a military pension on this basis. ${ }^{146}$ William's eligibility for a war pension was never questioned, despite the existence of at least some medical doubt surrounding its connection to the war. ${ }^{147}$ Unlike other disabled returned soldiers, who were allocated doctors by the Defence Department, William experienced a great degree of mobility and autonomy in his dealings with members of the medical profession. This freedom came at considerable expense. It was not idly that William's Sydney doctor enquired of Mary in 1917 whether 'Willie were dependent on his profession'. Mary's reply, “No, we are able \& willing to pay anything we can for a return of his health", would have been beyond the reach of most returned soldiers with similar conditions. ${ }^{148}$

Significantly, 'overcoming' implied a rejection of the feminised state of dependence represented by the care of family members. Accounts of disabled soldiers centring on the importance of a soldiers' individual willpower in effecting a recovery could admit little space to the sacrifices that family members made in caring for such

\footnotetext{
143 'New Member,' Northern Advocate, 11 November 1921, 8.

144 Tennant, The Fabric of Welfare, 87.

145 Walker, 'The Living Death,' 125-126.

146 See Ibid., 49-50.

147 William's friend and fellow enlistee Thomas Seddon was the chair of the War Pensions Board from 1930 to 1964 , and William personally corresponded with Seddon during this period to arrange the payment of his military pension, which he drew to cover the costs of the wages for his personal attendant in Parliament.

148 Mary to Rachel, 28 November 1917, MS-0985-040/004, HL.
} 
men. The Free Lance framed William's return to Parliament as proof that 'his spirit rises above his infirmity', noting that 'many a stronger man would be hopelessly on his back and being waited on hand and foot'. ${ }^{149}$ Similarly, speaking in 1920 upon the work of the famous St Dunstan's hospital for the blind in England, of which he was a former patient, Clutha Mackenzie cited the example of a blind man who, before entering the hospital, was 'confined to his room and waited upon hand and foot by his mother. $\mathrm{He}$ became broken in health, morbid, and miserable'. After his admission to St Dunstan's, however, the same man was transformed into a 'prosperous bootmaker...keeping his mother'. ${ }^{150}$ Thus, it was only by rejecting the feminised state of dependency represented by his mother's care that the blinded man could restore the appropriate gender order by himself becoming an independent breadwinner for his mother. As Marina Larsson has argued in the Australian context, disabled soldiers' path to recovery was typically depicted as a "journey towards "manly independence" and away from the feminising effects of dependency. Such representations, as Larsson has noted, depicted men as autonomous actors entirely outside of the family contexts to which they almost always returned, disavowing the unpaid family labour involved in caring for disabled veterans. $^{151}$

\section{Conclusion}

The Stewart family's experience of disability was inflected by their class status, wealth and connections. Mary's labour in caring for her brother and performing the range of intimate tasks necessary for his daily care was materially aided by the help of the family's domestic servants and other paid employees. Even with this assistance William's care still occupied much of his sister's time and energy. William's ability to travel to seek out alternative medical opinions would have been equalled by few other disabled veterans. Yet, in other respects, the Stewart family's experience was similar to that of other families who assumed the role of primary carers for disabled soldiers after the war. The closure of the government's Rehabilitation Department in 1922 meant that even severely disabled men would have had little choice but to rely upon families or voluntary agencies for their care. Yet, the emphasis on the centrality of individual willpower to disabled soldiers' recovery admitted no place for the role that a soldier's family members played in this process. Despite the centrality of family support to the lives of men like

\footnotetext{
149 'All Sorts of People,' Free Lance, 31 October 1918, 4.

150 untitled, Colonist, 17 March 1920, 2.

${ }^{151}$ Larsson, Shattered Anzacs, 24-25.
} 
William Downie Stewart, narratives of 'overcoming' rendered families virtually invisible as participants in disabled men's lives in the interwar period. 


\section{CONCLUSION}

The title of this thesis - An Unbroken Connection - points to the fundamental tension between family connection and disconnection that lies at this study's heart. During the war, the lives of many thousands of New Zealand families were torn apart. In many cases, the family ruptures brought about by war proved permanent. Grief and bereavement did not respect geographical boundaries and rendered the divisions of home and front arbitrary. War, as the author of one of George Stewart's memorial tributes put it, 'brought the constant burden of anxiety \& the bitterness of grief into the remotest valleys \& hamlets, removed by the width of the world from the immediate scene of strife'. ${ }^{1}$ Yet, despite the immense pressures war placed upon family life, family bonds frequently proved resilient. It has been a key contention of this thesis that family ties formed a significant and lasting source of connection between home and front, capable of overcoming the geographical distances which some scholars have equated with psychological or experiential gulfs. The continuous flow of goods, funds, knowledge and people back and forth between these spheres during the war confounded the neat categories of home and front, demonstrating the divisions between the two fronts to be, as First World War historian Susan Grazyel has put it, 'porous'.

In war, the ultimate broken connection was death. Yet, while death signalled a final severing of family ties in one respect, it could also lead to the formation of new bonds forged out of the collective experience of bereavement. When George Stewart died in 1915, the families, friends, and acquaintances who sent letters of condolence to his bereaved relatives or gathered together to commemorate his life participated in larger communities of mourning. Common religious beliefs and widely shared values such as duty and service were central to these communities' efforts to console bereaved relatives or attach meaning to their collective losses. Such circles of mourners reflected epistolary communities as well as those centred on particular localities. After George's death, his widow Elizabeth Stewart sought to keep her husband alive through

\footnotetext{
${ }^{1}$ John Collie, notes for speech delivered at unveiling of memorial plaque, January 1917, MS-0985-033/010, HL.
} 2 Grayzel, Women's Identities at War, 11. 
strengthening her relationship with his surviving siblings. Elizabeth's attraction to Spiritualism as a means of connecting to her husband George beyond the final borderline of death was shared by other wartime mourners. Yet, bonds forged in the immediacy and rawness of grief could have a limited lifespan. The urgency with which Elizabeth sought contact with her husband's family diminished over time. Her decision to remarry - seen as disloyalty to George's memory by some of his family members effectively spelt the end of this relationship based upon a shared bond with a deceased individual. Elizabeth's efforts to maintain a line of communication with George in a spiritual sense also bore little fruit: pointing to the limitations of Spiritualism as a source of comfort to the war bereaved.

The gendered paths of duty that men and women travelled in wartime can be traced through the lives of individual members of the Stewart family. In wartime, men's ultimate duty was seen to be to enlist for the armed forces. Both George Stewart and William Downie Stewart framed their decisions to volunteer as 'duty', while public responses to William's highly publicised enlistment in 1915 agreed that military service represented the highest expression of masculine duty. Whether voluntarily or by compulsion, men who were mobilised as part of New Zealand's civilian army prioritised the war over responsibilities to family. However, the belief that men's ultimate duty lay with the war did not necessarily spell the diminishment of their existing attachments to home and family. The polarised Victorian moral framework of service or selfishness through which the Stewarts and other members of their influential middle- and upperclass circles viewed the war provided a means of differentiating between the path of one's duty and the direction of one's personal preferences. In fact, the clash between the two was key: it was only when duty and personal inclinations collided that men were called upon to exercise the will-power and self-control so prized by Victorians.

In wartime, duty was measured by the family unit: entire families made 'sacrifices' or shirked their responsibilities. While middle- and upper-class men emphasised the personal sacrifices that leaving home and family behind represented the pain of separation further attesting to the depth of the sacrifice - they nevertheless insisted that men's larger call to duty lay in the defence of Empire, and that men who placed domestic responsibilities before the needs of the nation acted selfishly. This overwhelming middle-class emphasis on the war as duty concealed other perspectives. 
The belief that men's ultimate duty was to the war effort clashed with the masculine codes of breadwinner and provider that many working-class men subscribed to by the early twentieth century. The middle-class moral framework of service or selfishness failed to recognise that some men prioritised duty differently while neglecting to acknowledge the far greater relative sacrifices that the departures of male earners could represent for working-class households.

Men's existing attachments to, and sense of responsibility towards, families did not cease with their mobilisation overseas. The records of men's wartime correspondence to patriotic organisations reflect the efforts of some working-class men to stay actively involved in their families' affairs in spite of wartime separations. Here the OSDWC and its visitors performed a critical role as intermediaries in family life during the war: providing the conduit through which men could continue to enact their domestic roles from afar, and forming a further instance in which quasi-familial relationships acted to overcome the family distances of war. Men's continuing identification with domestic responsibilities in spite of wartime separation supports historian Martin Francis's argument that '[i]f there was a "flight from domesticity" in the late Victorian and Edwardian periods, it was unable to claim a monopoly over the masculine imagination, which was characterized by contradictory patterns of desire and self-identification'. ${ }^{3}$ However, an exclusive emphasis on men who wrote regular letters to their families or who raised their families' plight in correspondence to patriotic societies during the war risks painting an overly rosy picture of family relationships in wartime. As chapter five suggested, the war could also create fissures in family life. Some men's abuse or neglect of their wives and children was long-standing: for such families the separations of war may well have brought about a welcome respite from physical or emotional abuse. Here, again, distance offered a form of protection. Not every individual wished to bridge the family distances of war.

The competing demands between men's domestic attachments and calls on men's duty that took them outside the home are a further example of what John Tosh has termed the 'dialectic between opposing tendencies' that has characterised men's relationship with domesticity from at least the early nineteenth century. ${ }^{4}$ One window into the tensions between men's domestic identity and military ideals of masculinity is

${ }^{3}$ Francis, 'The Domestication of the Male?,' 643.

${ }^{4}$ Tosh, A Man's Place, 7. 
provided by the significant set of condolence letters received by George Stewart's family members after this death. Condolence letter writers highlighted the masculine attributes they most admired in George Stewart. Analysis of these letters suggest that the heroic tropes of military masculinity never entirely supplanted celebration of civilian attributes in homefront expressions of condolence. Those who mourned the loss of George Stewart expressed their admiration of his qualities as a neighbour, colleague or family man more frequently than they praised his conduct as a soldier or officer. Furthermore, those who celebrated George Stewart's willingness to sacrifice all for his duty tended to see his actions in volunteering for war as just the latest episode in an entire life lived for 'others'.

Duty was also an important motivation for the middle- and upper-class New Zealand women such as Elizabeth Stewart who travelled overseas to places in close proximity to the battlefront with the aim of being near to relatives in the armed forces, or with the notion of 'doing something' for the war effort. For such women, family duty and the war effort frequently overlapped. A consensus existed during the war that any women who entered new forms of work would do so 'only for the duration', and would be activated solely by 'selfless' patriotic motives. Yet, for the individuals concerned, their experiences during the war had the potential to enrich their lives and broaden their personal horizons. While the war had been personally devastating for her, Elizabeth Stewart freely acknowledged that others had experienced it differently and that duty brought its rewards as well as costs. Sitting in the Brockenhurst rest room in November 1918 attempting to write a letter to her brother-in-law William, Elizabeth found herself 'very much diverted' by the talk of 'various groups of girls'. She added: 'Some of us are perhaps too inclined to think that the war has brought about the end of all things that matter (individually) but it warms one's heart to realize that for another section of the community it has opened a broader outlook \& brought countless treasures of experience, knowledge, friendship, \& love into lives that would otherwise have been narrow \& colourless' ${ }^{5}$

Whatever the impact of the war on its individual participants, the war did not alter the belief that women's ultimate duties lay in family life. While female volunteers who served overseas were praised for their willingness to serve the war effort, the same

\footnotetext{
${ }^{5}$ Elizabeth to William, 3 November 1918, MS-0985-007/004, HL.
} 
individuals were also expected to place family before the war effort as soon as the two conflicted. The contributions of these female volunteers quickly faded from public view after the war. While the war service of returned servicemen continued to receive public acclaim in the 1920s and 1930s, former voluntary workers struggled to have their service officially acknowledged. Volunteers' personnel files record the effort of such women to gain the same recognition and benefits enjoyed by returned servicemen. ${ }^{6}$ As a 1961 letter from former First World War VAD nurse Marion Falconer to the Army Headquarters recognised, the absence of an official record had the capacity to shape family memories of war in the generations to come. Falconer wrote: 'just lately some nieces were saying that the men folk of the original family had made a name for themselves... but the womenfolk had not done anything. I said but Aunt Annie and self did have our War Service mentioned and was promptly asked what we got and had to say - read it in the Papers. Should we have some written record of this??7

Just as such ideals of duty and service pre-dated the war, they were not extinguished by it. As chapter six illustrated, disabled veteran MPs like William Downie Stewart continued to be depicted as embodiments of their earlier willingness to sacrifice themselves for the war effort well after the conflict's end. Thus the thesis provides further evidence to support historian Janet Watson's contention that the emergence of 'disillusionment' as a response to the war in the late 1920s was indicative less of an abrupt change in how society as a whole viewed the war than part of a more gradual generational shift: 'There was no identifiable turning point... when traditional ways of imagining the war and one's role in it were no longer comprehensible... For many of the British men and women who were active participants in the First World War, the languages of honor, patriotism, and self-sacrifice for a greater good never lost their currency'. ${ }^{8}$ Duty, chapter six suggested, continued to characterise the way in which the Stewarts and members of their late Victorian generation looked back upon the war for the entirety of their lives.

\footnotetext{
6 'Miss Margaret Doyle Taylor - personnel file,' AABK-22525-W5714/2/B.R.37/131B, ANZ; 'Miss Mona Winifred Cunningham - personnel file,' AABK-22525-W5714/1/BR-37/21B, ANZ.

${ }^{7}$ Miss M. Falconer to Officer-in-Charge, Army Headquarters, 22 February 1961, in 'Miss May Falconer - personnel file,' AABK-22525-W5714-1/B.R.37/1C, ANZ. Unlike the female volunteers who are the subject of chapter two, the service of Miss Falconer and her sister took place entirely in New Zealand, in hospitals attached to the military camps at Featherston and Trentham.

8 Watson, Fighting Different Wars, 308.
} 
Writing of family life in Paris, London and Berlin during the war, historian Catherine Rollet has claimed that 'wartime pressure tended to highlight what families of all social groups had in common'. 'Some aspects of the family experience of the war examined in this thesis support Rollet's conclusion. The fact of wartime deaths, the temporary or permanent disruptions of family lives and the frequency of war-related mobility were features of the experience of war for families of all social backgrounds. Nevertheless, this thesis has pointed to important class-bound divisions in the ways that such universal phenomena of the war as bereavement were experienced by families. In a number of respects, affluent families like the Stewarts had significant advantages over their poorer counterparts. The drop in household income which almost invariably accompanied soldiers' departure for war had a far greater impact on families already struggling than it did on the comfortably-off. For the upper-class women discussed in chapter two, mobility meant relocating their place of residence to England to be nearer their menfolk. By contrast, for the working-class women who were the subject of chapter five, mobility was far more likely to be forced by the necessity to seek out cheaper accommodation or wider family support.

The mobility of Elizabeth Stewart and her ilk during wartime allowed them to reverse what was the characteristic experience of grief for dominion families. Through mobility, such individuals were able to overcome the worst effects of the family separations of war. Having a soldier relative hospitalised was less distressing for families who were able to visit and witness their loved one's condition in person. The family separations of war were far less prolonged for those able to renew family ties during visits home on leave. In rare cases, such as that of Elizabeth Stewart, individual travellers were able to overcome the absence of bodies to mourn which formed a defining feature of bereavement for families in virtually all combatant nations. While Elizabeth was able to share her husband's last hours of life with him and attend his burial, most New Zealand families had little choice but to let others act on their behalf in this most intimate of rites. Families' wealth and opportunities for travel continued to shape their experiences of bereavement well after the end of hostilities: some well-off families could afford the pilgrimage to visit distant war graves. ${ }^{10}$

\footnotetext{
${ }^{9}$ Rollet, 'The Home and Family Life,' 318

10 Ziino, A Distant Grief, 165.
} 
Those individuals or families who were unable to personally bridge the distances of war were not simply passive victims or frustrated onlookers to an event that took place elsewhere. Families displayed considerable versatility in their efforts to overcome the separations of war. Families kept in touch with soldier relatives and friends through correspondence, and maintained a seemingly endless stream of parcels of clothing and favourite foods for loved ones in the armed forces overseas. Their efforts were matched by women's patriotic organisations. During the war, this traffic in parcels and other donated goods and funds formed a continuous link between individuals, families and voluntary organisations in New Zealand and frontline soldiers, challenging the existence of a rigid separation between these spheres. The detailed planning and logistical work involved in preparing and shipping thousands of parcels from New Zealand to the front monthly entailed an indepth knowledge of constantly evolving conditions at the front which contradicts any remaining claims that civilians knew 'nothing' of what soldiers experienced. The informal personal and kinship networks of upper-class female volunteers - located either in the proximity of the front or working for patriotic organisations back in New Zealand - performed an essential role as conduits of news, information, goods and funds between home and front. Through their work, the domains of home and front are revealed as interconnected.

In a letter to Mary Downie Stewart, written from the front in France in 1916, Otago soldier John MacManus wrote: '[W] hen one realises how the concentrated energy of the men and women are centred in this great fight, each battling in their respective spheres, a feeling grows more day by day, that it is good to be alive to help in some capacity. ${ }^{11}$ MacManus here articulated a vision of the war effort as a shared endeavour between men and women, in which each sex 'battled' in equal yet complementary spheres towards a common cause. It was an expression of women's contribution to the war effort that would have found favour among the leadership of women's patriotic organisations. During the war the leadership of the OSWPA and other women's patriotic societies promoted an essentialised vision of feminine nature to lay claim to the unique nature of their contributions to the war effort. In this way, the language of adoptive kinship provided women's organisations with a powerful mandate to take part in the war. Even women fully occupied by household duties could participate: the rhetoric of women's patriotic organisations transformed ordinary domestic tasks into

${ }^{11}$ J. E. MacManus to Mary, 15 October 1916, MS-0985-051/015, HL. 
patriotic acts. The organisers of parcels for frontline soldiers drew upon separate spheres ideology to carve out a place for themselves in the war effort. It was female volunteers, not government or military officials, they asserted, who were uniquely qualified to bridge the distances of war and to bring the emotional and practical comforts of home to soldiers in the trenches.

The highly sentimentalised vision of the family employed by women's voluntary organisations was fraught with contradictions. In their efforts to trade upon idealised notions of family life, women's organisations conversely drew attention to the failures of families to meet the ideal. The lonely soldier - a stock figure in the publicity of women's patriotic organisations during the war - highlighted the fact that some families were remiss in their duty of sending parcels to soldier relatives. The efforts of publicly prominent female leaders such as Mary Downie Stewart to lay claim to women's qualification for public life on the basis of virtues centred in home and family also contained deep tensions. Historian Frank Prochaska's observations in relation to nineteenth-century female philanthropists also apply here. While women's claims to 'special virtues' as women could provide a 'means of emancipation' and an entry point into public life, it could also represent 'a snare': such women 'could only give up a belief in the distinctions between the sexes at some peril'. ${ }^{12}$ It was nevertheless a strategy that women activists would continue to pursue well into the interwar period. ${ }^{13}$

In this thesis, family has provided the means of moving between domains or categories often treated as distinct and mutually opposing: public and private, soldier and civilian, home and front - with each successive movement further blurring the boundaries between them. The war permeated family life during the war, irrespective of social background or distance from the battlefronts. Family homes formed the sites of some of the most intense emotional experiences of the war, and the locations where its most long-lasting effects played out. Family comprised the fulcrum on which men's and women's duty turned. Inserted into organisational objectives, notions of fictive kinship provided the means by which the bonds between home and front, civilians and combatants, could be conceptualised, and supplied patriotic women with their mandate to participate in the war effort. In framing its analysis around a particular family and the archival journeys opened up through their lives, this study has told only one of an

12 Prochaska, Women and Philanthropy, 225-226.

${ }^{13}$ See Nolan, Breadwinning, chapter five. 
endless variety of possible 'family stories' of this conflict. While every family's experience was different, the centrality of families to the war experience is indisputable. Families were not passive bystanders to the war, but a significant locus of the war experience. Whether near-at-hand or distant, families - in their physical and symbolic manifestations - are central to understanding the First World War. Family was much more than a biological unit, but a language and imagery crucial to the war experience. 

BIBLIOGRAPHY

\title{
PRIMARY SOURCES
}

\section{UNPUBLISHED PAPERS}

\author{
Alexander Turnbull Library, Wellington \\ G. H. Scholefield Collection, MS-Papers-0212. \\ Knight Family Papers, MS-Papers-5548-11. \\ Seddon Family Collection, MS-Papers-1619.
}

\section{Archives New Zealand, Wellington and Dunedin offices}

Army Department. 'Demobilisation - Gratuities - Nurses and VAD workers.' R22436561, AAYS-8638-AD1-1053- 75/26/11.

Army Department, 'New Zealand War Contingent Association - general file.' R22432221, AAYS-8638-AD1-887/39/189.

Army Department. 'Camps - YMCA - social work with NZEF.' R22429932, AAYS8638-AD1-742/12/103.

New Zealand Defence Force Personnel Archives, Base Records Filing System, AABK22525, accessions W5573, W5614, and W5714.

New Zealand Defence Force Personnel Archives, Military Personnel Files, AABK11805.

George Hepburn Stewart - probate file. DAAD/9075/341/3386.

Elizabeth Taylor - probate file. DAAC/9076/728/602/67.

\section{Auckland War Memorial Museum}

Luxford, Gladys, 'How I came to be interested in war \& why I went to World War One', MS 94/6. 


\section{Hocken Library, Dunedin}

Otago Patriotic Council records ARC-0514/002.

Otago Patriotic and General Welfare Association records, ARC-0514/001.

Our Soldiers' Queen Committee Minute Book, 1915, Misc-MS-0100.

World War I Case Files, AG-113/040 - AG-113/155.

William Downie Stewart - Personal, Political and Family Papers, ARC-0164/001 to ARC-0165/011.

\section{Macmillan Brown Library, Christchurch}

G W Armitage Papers, MB 391.

George Whitefield Armitage collection, MB 312.

William Downie Stewart - Armitage Family Papers, MB 458.

\section{Toitū Otago Settlers' Museum, Dunedin}

Otago Women's Patriotic Association records, Jean Burt Papers, AG-73, Series 1 - 9.

\section{OFFICIAL PUBLICATIONS}

Appendices to the Journals of the House of Representatives.

New Zealand Official Year Books.

Results of a Census of the Dominion of New Zealand Taken for the Night of $17^{\text {th }}$ April, 1921.

Wellington: Government Printer, 1925.

\section{NEWSPAPERS and PERIODICALS}

Ashburton Guardian

Auckland Star

The British Australasian 
British Medical Journal

Chronicles of the New Zealand Expeditionary Force

\section{Dominion}

Evening Post

Evening Star

Free Lance

Grey River Argus

Kai Tiaki: The Journal of the Nurses of New Zealand.

Hawera \& Normanby Star

Oamaru Mail

Observer

Otago Daily Times

Otago Witness

Quick March

Maoriland Worker

Marlborough Express

New Zealand Herald

NZ Truth

Northern Advocate

The Outlook

The Press

Sydney Morning Herald

Tapanui Courier

Tuapeka Times

Wanganui Chronicle 


\section{OTHER PUBLISHED PRIMARY SOURCES.}

Christ in You. London: J. M. Watkins, 1910.

Browning, Robert. Asolando: Fancies and Facts. Boston: Houghton, Mifflin and Company, 1890.

Doyle, Arthur Conan. New Revelation. London: Hodder and Stoughton, 1918.

Fanning, L. S., ed. The Call of the Camps: the Only Way, a Man's Way to Save the State. Wellington: Blundell Bros., 1916.

- Winning Through From W ar to Peace: New Zealand. Wellington: Govt. Printer, 1919.

Hankey, Donald. A Student in Arms. New York: E.P. Dutton \& Co., 1917.

Heslop, Fanny. Speaking Across the Border-line: Being Letters from a Husband in Spirit Life to his wife on Earth. London: C. Taylor, 1912.

Jinarajadasa, Curuppumullage. What We Shall Teach. Madras (Chennai): Theosophical Publishing House, 1915.

Le Rossignol, James Edward, and William Downie Stewart. State Socialism in New Zealand. London: Harrap, 1910.

Lodge, Sir Oliver. Raymond, or, Life and Death: with Examples of the Evidence for Survival of Memory and Affection after Death. London: Methuen and Co., 1916.

—. The Vital Message. New York: George H. Doran, 1919.

Maclean, Norman. The Great Discovery . Glasgow: J. Maclehose and Sons, 1915.

Oxenham, John. 'All's Well!': Some Helpful Verse for these Dark Days of War. London: Methuen \& Co. Ltd, 1915.

Stewart, William Downie. A Brief History of the Dunedin Club (Otherwise Known as the Fernbill Club). Dunedin: Coulls Somerville Wilkie, 1948.

- The Journal of George Hepburn: on his Voyage from Scotland to Otago in 1850.

Dunedin: Coulls Somerville Wilkie, 1934.

- Mr Justice Richmond and the Taranaki War of 1860: A Great Judge Vindicated.

Wellington: A. H. and A. W. Reed, 1947.

- Portrait of a Judge: Sir Joshua Strange Williams P.C. Wellington: Whitcombe \& Tombs, 1945. 
The Right Honourable Sir Francis H. D. Bell, P.C., G.C.M.G., K.C.: His Life and Times. Wellington: Butterworth \& Co., 1937.

William Rolleston: A New Zealand Statesman. Christchurch: Whitcombe \& Tombs Limited, 1940.

Wises New Zealand Post Office Directory 1905. Auckland: BAB Microfilming, 1992.

Wises New Zealand Post Office Directory 1910. Auckland: BAB Microfilming, 1992.

Wises New Zealand Post Office Directory 1915. Auckland: BAB Microfilming, 1995.

\section{SECONDARY SOURCES}

\section{BOOKS}

Acton, Carol. Grief in Wartime: Private Pain, Public Discourse. Basingstoke: Palgrave Macmillan, 2007.

Anderson, Atholl. The Welcome of Strangers: an Ethnobistory of Southern Maori A.D. 16501850. Dunedin: Otago University Press, 1993.

Audoin-Rouzeau, Stephane. Men at War 1914-1918: National Sentiment and Trench Journalism in France during the First World War. Translated by Helen McPhail. Oxford, Washington D.C.: Berg, 1992.

Audoin-Rouzeau, Stephane, and Annette Becker. 14-18: Understanding the Great War. Translated by Catherine Temerson. New York: Hill \& Wang, 2002.

Baker, Paul. King and Country Call: New Zealanders, Conscription and the Great War. Auckland: Auckland University Press, 1988.

Ballantyne, Tony. Webs of Empire: Locating New Zealand's Colonial Past. Wellington: Bridget Williams Books, 2012.

Ballantyne, Tony, and Antoinette Burton, eds. Moving Subjects: Gender, Mobility and Intimacy in an Age of Global Empire. Urbana: University of Illinois Press, 2009.

Ballantyne, Tony, and Brian Moloughney, eds. Disputed Histories: Imagining New Zealand's Pasts. Dunedin: Otago University Press, 2006.

Barnes, Felicity. New Zealand's London: A Colony and its Metropolis. Auckland: Auckland University Press, 2012.

Bassett, Michael. Coates of Kaipara. Auckland: Auckland University Press, 1995. 
The State in New Zealand 1840-1984: Socialism Without Doctrines? Auckland:

Auckland University Press, 1998.

Blackmore, Kate. The Dark Pocket of Time: War, Medicine and the Australian State, 19141935. Adelaide: Lythrum Press, 2008.

Bland, Lucy. Banishing the Beast: English Feminism and Sexual Morality 1885-1914. London: Penguin, 1995.

Bourke, Joanna. Dismembering the Male: Men's Bodies, Britain and the Great War. London: Reaktion Books, 1996.

Working-Class Cultures in Britain, 1890-1960: Gender, Class and Ethnicity. London: Routledge, 1994.

Boyack, Nicholas. Bebind the Lines: the Lives of New Zealand Soldiers in the First World War. Wellington: Allen \& Unwin/Port Nicholson Press, 1989.

Boyack, Nicholas, and Jane Tolerton. In the Shadow of War: New Zealand Soldiers Talk About World One War and Their Lives. Auckland: Penguin, 1990.

Braude, Ann. Radical Spirits: Spiritualism and Women's Rights in Nineteenth-Century America. $2^{\text {nd }}$ ed. Bloomington: Indiana University Press, 2001.

Braybon, Gail. Women Workers in the First World War. London: Croom Helm, 1981. ., ed. Evidence, History and the Great War: Historians and the Impact of 1914-18. New York: Berghahn Books, 2003.

Braybon, Gail, and Penny Summerfield, eds. Out of the Cage: Women's Experiences in Two World Wars. London: Pandora Press, 1987.

Bressler, Ann Lee. The Universalist Movement in America, 1770-1880. Oxford: Oxford University Press, 2001.

Brickell, Chris. Mates \& Lovers: A History of Gay New Zealand. Auckland: Random House New Zealand, 2008.

Brookes, Barbara, ed. At Home in New Zealand: Houses, History, People. Wellington: Bridget Williams Books, 2000.

Brookes, Barbara, Annabel Cooper, and Robin Law, eds. Sites of Gender: Women, Men and Modernity in Southern Dunedin, 1890-1939. Auckland: Auckland University Press, 2003.

Brookes, Barbara, Charlotte Macdonald, and Margaret Tennant, eds. Women in History: Essays on Women in New Zealand. Wellington: Allen \& Unwin/Port Nicholson Press, 1986. 
, eds. Women in History 2: Essays on Women in New Zealand. Wellington: Bridget

Williams Books, 1992.

Bueltmann, Tanja. Scottish Ethnicity and the Making of New Zealand Society, 1850-1930.

Edinburgh: Edinburgh University Press, 2011.

Burton, Antoinette, ed. Archive Stories: Facts, Fictions, and the Writing of History. Durham, North Carolina: Duke University Press, 2005.

Bush, Julia. Edwardian Ladies and Imperial Power. London: Leicester University Press, 2000.

Byrne, Georgina. Modern Spiritualism and the Church of England, 1850-1939. Woodbridge, Suffolk: The Boydell Press, 2010.

Byrnes, Giselle, ed. The New Oxford History of New Zealand. Melbourne: Oxford University Press, 2009.

Callister, Sandy. The Face of War: New Zealand's Great War Photography. Auckland: Auckland University Press, 2008.

Carden-Coyne, Ana. Reconstructing the Body: Classicism, Modernism, and the First World War. Oxford: Oxford University Press, 2009.

Carkeek, Rikihana Home Little Maori Home: A Memoir of the Maori Contingent, 1914-1916. Wellington: Totika Publications, 2003.

Clark, Anna. The Struggle for the Breeches: Gender and the Making of the British Working Class. London: Rivers Oram Press, 1995.

Cohen, Deborah. The War Come Home: Disabled Veterans in Britain and Germany, 19141939. Berkeley; Los Angeles: University of California Press, 2001.

Coleborne, Catharine. Madness in the Family: Insanity and Institutions in the Australasian Colonial World, 1860-1914. Basingstoke: Palgrave Macmillan, 2010.

Collini, Stefan. Public Moralists: Political Thought and Intellectual Life in Britain, 1850-1930. Oxford: Clarendon Press, 1991.

Comacchio, Cynthia R. The Infinite Bonds of Family: Domesticity in Canada, 1850-1940. Toronto: University of Toronto Press, 1999.

Cooke, Miriam, and Angela Woollacott, eds. Gendering War Talk. Princeton: Princeton University Press, 1993.

Cowan, James. The Maoris in the Great War: a History of the New Zealand Native Contingent and Pioneer Battalion: Gallipoli 1915, France and Flanders 1916-1918. Auckland: Maori Regimental Committee, 1926. 
Crais, Clifton, and Pamela Scully. Sara Baartman and the Hottentot Venus: A Ghost Story and a Biography. Princeton: Princeton University Press, 2009.

Crawford, John, ed. No Better Death: the Great War Diaries of William G. Malone. Auckland: Reed Books, 2005.

Crawford, John, and Ian McGibbon. New Zealand's Great War: New Zealand, the Allies \& the First World War. Auckland: Exisle Publishing, 2007.

Crotty, Martin. Making the Australian Male: Middle-Class Masculinity 1870-1920.

Melbourne: Melbourne University Press, 2001.

Daley, Caroline. Girls \& Women, Men \& Boys: Gender in Taradale, 1886-1930. Auckland: Auckland University Press, 1999.

Daley, Caroline, and Deborah Montgomerie, eds. The Gendered Kiwi. Auckland: Auckland University Press, 1999.

Dalley, Bronwyn. Family Matters: Child Welfare in Twentieth-Century New Zealand. Auckland: Auckland University Press, 1998.

Damousi, Joy. The Labour of Loss: Mourning, Memory and Wartime Bereavement in Australia. Cambridge: Cambridge University Press, 1999.

- Living with the Aftermath: Trauma, Nostalgia and Grief in Post-War Australia. Cambridge: Cambridge University Press, 2001.

Damousi, Joy, and Marilyn Lake, eds. Gender and War: Australians at War in the Twentieth Century. Cambridge: Cambridge University Press, 1995.

Darrow, Margaret. French Women and the First World War. Oxford: Berg, 2000.

Das, Santanu. Race, Empire and First World War Writing. Cambridge: Cambridge University Press, 2011.

Davidoff, Leonore. Thicker Than Water: Siblings and their Relations 1780-1920. Oxford: Oxford University Press, 2012.

Davidoff, Leonore, and Catherine Hall. Family Fortunes: Men and Women of the English Middle Class 1780-1850. Rev. ed. London: Routledge, 2002.

Davidoff, Leonore, Megan Doolittle, Janet Fink, and Katherine Holden. The Family Story: Blood, Contract and Intimacy 1830-1960. London: Longman, 1999.

Davis, Belinda. Home Fires Burning: Food, Politics, and Everyday Life in World War I Berlin. Chapel Hill: University of North Carolina Press, 2000.

Dawson, Graham. Soldier Heroes: British Adventure, Empire and the Imagining of Masculinities. London: Routledge, 1994. 
Deacon, Desley, Penny Russell, and Angela Woollacott, eds. Transnational Lives:

Biographies of Global Modernity, 1700-Present. Basingstoke: Palgrave Macmillan, 2010.

Dixon, Joy. Divine Feminine: Theosophy and Feminism in England. Baltimore: Johns Hopkins University Press, 2001.

Dudink, Stefan, Karen Hagemann, and John Tosh, eds. Masculinities in Politics and War: Gendering Modern History. Manchester: Manchester University Press, 2004.

Duffett, Rachel. The Stomach for Fighting: Food and the Soldiers of the Great War. Manchester: Manchester University Press, 2012.

Ellwood, Robert S. Islands of the Dawn: The Story of Alternative Spirituality in New Zealand. Honolulu: University of Hawaii Press, 1993.

Else, Anne, ed. Women Together: A History of Women's Organisations in New Zealand: Nga Ropu Wabine o te Motu. Wellington: Daphne Brassell Associates; Department of Internal Affairs, 1993.

Fenton, Damien. New Zealand and the First World War: 1914-1918. Auckland: Penguin, 2013.

Francis, Andrew. 'To Be Truly British We Must Be Anti-German': New Zealand, Enemy Aliens and the Great War Experience, 1914-1919. Oxford: Peter Lang, 2012.

Frawley, Maria S. Invalidism and Identity in Nineteenth-Century Britain. Chicago: University of Chicago Press, 2004.

Fussell, Paul. The Great W ar and Modern Memory. New York: Oxford University Press, 1975.

Gabay, Alfred. Messages from Beyond: Spiritualism and Spiritualists in Melbourne's Golden Age, 1870-1890. Melbourne: Melbourne University Press, 2001.

Gammage, Bill. The Broken Years: Australian Soldiers in the Great War. Canberra: Australian National University Press, 1974.

Garton, Stephen. The Cost of War: Australians Return. Melbourne: Oxford University Press, 1996.

Gerber, David A. Disabled Veterans in History. Ann Arbor: University of Michigan Press, 2000.

Gilding, Michael. The Making and Breaking of the Australian Family. Sydney: Allen \& Unwin, 1991.

Gordon, Linda. Heroes of their Own Lives: the Politics and History of Family Violence. New York: Penguin, 1988. 
Grant, David. Field Punishment No 1: Archibald Baxter, Mark Briggs \& New Zealand's AntiMilitarist Tradition. Wellington: Steele Roberts, 2008.

Grayzel, Susan. Women's Identities at War: Gender, Motherhood, and Politics in Britain and France during the First World War. Chapel Hill: The University of North Carolina Press, 1999.

Griffith, Penny, Ross Harvey, and Keith Maslen, eds. Book \& Print in New Zealand: A Guide to Print Culture in New Zealand. Wellington: Victoria University Press, 1997. http://nzetc.victoria.ac.nz/tm/scholarly/tei-GriBook.html, accessed 18 February 2014.

Grimshaw, Patricia. Women's Suffrage in New Zealand. Rev. ed. Auckland: Auckland University Press, 1987.

Grimshaw, Patricia, Chris McConville, and Ellen McEwen, eds. Families in Colonial Australia. Sydney: George Allen \& Unwin Australia, 1985.

Gullace, Nicoletta F. 'The Blood of Our Sons': Men, Women, and the Renegotiation of British Citizenship During the Great War. New York: Palgrave Macmillan, 2002.

Gustafson, Barry. The First 50 Years: A History of the New Zealand National Party. Auckland: Reed Methuen: 1986.

- Labour's Path to Political Independence: The Origins and Establishment of the New Zealand Labour Party 1900-19. Auckland: Auckland University Press, 1980.

Hareven, Tamara, and Andrejs Plakans, eds. Family History at the Crossroads: A Journal of Family History Reader. New Jersey: Princeton University Press, 1987.

Harper, Glyn, ed. Letters from Gallipoli: New Zealand Soldiers Write Home. Auckland: Auckland University Press, 2011.

Hazelgrove, Jenny. Spiritualism and British Society between the Wars. Manchester: Manchester University Press, 2000.

Higonnet, Margaret, Jane Jenson, Sonya Michel, and Margaret Collins Weitz, eds. Bebind the Lines: Gender and the Two World Wars. Yale: Yale University Press, 1987.

Hodes, Martha. The Sea Captain's Wife: A True Story of Love, Race and W ar in the Nineteenth Century. New York: W. W. Norton \& Company, 2006

Horne, John, ed. State, Society and Mobilization in Europe during the First World War. Cambridge: Cambridge University Press, 1997.

Hunter, Kate. Father's Right-hand Man: Women on Australia's Family Farms in the Age of Federation, 1880s-1920s. Melbourne: Australian Scholarly Publishing, 2004. 
Hynes, Samuel. $A$ War Imagined: The First World W ar and English Culture. New York: Atheneum, 1991.

Ingram, N. M., ed. In Flanders Fields: the World War One Diary of Private Monty Ingram. Auckland: David Ling, 2006.

Israel, Kali. Names and Stories: Emilia Dilke and Victorian Culture. Oxford: Oxford University Press, 1999.

Jackson, H. R. Churches and People in Australia and New Zealand, 1860-1930. Wellington: Allen \& Unwin; Port Nicholson Press, 1987.

Jalland, Pat. Changing Ways of Death in Twentieth-Century Australia: War, Medicine and the Funeral Business. Sydney: University of New South Wales Press, 2006.

—. Death in the Victorian Family. Oxford, Oxford University Press, 1996.

Keene, Jennifer D., ed. Finding Common Ground: New Directions in First World War Studies. Leiden; Boston: Brill, 2011.

Koven, Seth. Slumming: Sexual and Social Politics in Victorian London. Princeton: Princeton University Press, 2004.

Lake, Marilyn, and Henry Reynolds. Drawing the Global Colour Line: White Men's Countries and the Question of Racial Equality. Melbourne: Melbourne University Press, 2008.

Lake, Marilyn, Henry Reynolds, Mark McKenna, and Joy Damousi. What's Wrong with Anzac? The Militarisation of Australian History. Sydney: University of New South Wales Press, 2010.

Larsson, Marina. Shattered Anzacs: Living with the Scars of War. Sydney: University of New South Wales Press, 2009.

Laugesen, Amanda. 'Boredom is the Enemy': The Intellectual and Imaginative Lives of Australian Soldiers in the Great War and Beyond. Farnham, Surrey: Ashgate, 2012.

Lee, Mary. The Not So Poor: An Autobiography. Edited by Annabel Cooper. Auckland: Auckland University Press, 1992.

Leed, Eric J. No Man's Land. Combat \& Identity in World War I. Cambridge: Cambridge University Press, 1979.

Lewis, Jane. Women and Social Action in Victorian and Edwardian England. California: Stanford University Press, 1991.

Lovell-Smith, Margaret. Plain Living High Thinking: The Family Story of Jennie and Will Lovell-Smith. Christchurch: Pedmore Press, 1995. 
Luckins, Tanja. The Gates of Memory. Australian People's Experiences and Memories of Loss and the Great War. Freemantle: Curtin University Books, 2004.

Lyons, Martyn. Reading Culture and Writing Practices in Nineteenth-Century France. Toronto: University of Toronto Press, 2008.

Lystra, Karen. Searching the Heart: Women, Men, and Romantic Love in Nineteenth-Century America. New York: Oxford University Press, 1989.

Macdonald, Charlotte, ed. The Vote, the Pill and the Demon Drink: A History of Feminist Writing in New Zealand, 1869-1993. Wellington: Bridget Williams Books, 1993.

Maclean, Chris, and Jock Phillips. The Sorrow and the Pride: New Zealand War Memorials. Wellington: Historical Branch, GP Books, 1990.

Macleod, Jenny, and Pierre Purseigle, eds. Uncovered Fields: Perspectives in First World War Studies. Leiden; Boston: Brill, 2004.

Mangan, J. A., and James Walvin. Manliness and Morality. Middle-Class Masculinity in Britain and America, 1800-1940. New York: St Martin's Press, 1987.

Marriott, Allan. Mud Beneath My Boots: A Poignant Memoir of the Effects of War on A Young New Zealander. Auckland: Harper Collins, 2005.

McAloon, Jim. No Idle Rich: The Wealthy in Canterbury and Otago 1840-1914. Dunedin: Otago University Press, 2002.

McCartney, Helen. Citizen Soldiers: The Liverpool Territorials in the First World War. Cambridge: Cambridge University Press, 2005.

McCaw, Bob, ed. Tale but Partly Told: The World War I Diaries \& Letters of W. T. McCaw. Wellington: McCaw Family, 1998.

McClure, Margaret. The Wonder Country: Making New Zealand Tourism. Auckland: Auckland University Press, 2004.

McGibbon, Ian, ed. The Oxford Companion to New Zealand Military History. Auckland: Oxford University Press, 2000.

McKinnon, Malcolm, ed. Bateman New Zealand Historical Atlas: Ko Papatuanuku e Takoto Nei. Auckland: David Bateman; Department of Internal Affairs, 1997.

McQuilton, John. Rural Australia and the Great War: From Tarrawingee to Tangambalanga. Melbourne: Melbourne University Press, 2001.

Mein Smith, Philippa. Mothers and King Baby: Infant Survival and Welfare in an Imperial World: Australia 1880-1950. Basingstoke: Macmillan Press Ltd, 1997. 
Meyer, Jessica. Men of W ar: Masculinity and the First World War in Britain. Basingstoke: Palgrave Macmillan, 2009.

Miller, Frederick Walter Gascoyne. Beyond the Blue Mountains: a History of the West Otago District. Dunedin: Otago Centennial Publications, 1954.

Morgan, David. Family Connections: An Introduction to Family Studies. Cambridge: Polity Press, 1996.

Morgan, Sue, and Jacqueline De Vries, eds. Women, Gender and Religious Cultures in Britain, 1800-1940. New York: Routledge, 2010.

Morris, R. J. Men, Women and Property in England, 1870-1870. Cambridge: Cambridge University Press, 2005.

Morton, Desmond. Fight or Pay: Soldiers' Families in the Great War. Vancouver: UBC Press, 2004.

Nolan, Melanie. Breadwinning: New Zealand Women and the State. Christchurch: Canterbury University Press, 2000.

- Kin: a Collective Biography of a Working-Class New Zealand Family. Christchurch: Canterbury University Press, 2005.

Olssen, Erik. An Accidental Utopia? Social mobility and the Foundations of an Egalitarian Society, 1880-1940. Dunedin: Otago University Press, 2011.

- Building the New World: Work, Politics and Society in Caversham, 1880s - 1920s. Auckland: Auckland University Press, 1995.

—.John A. Lee. Dunedin: University of Otago Press, 1977.

Oppenheim, Janet. The Other World: Spiritualism and Psychical Research in England, 18501914, Cambridge: Cambridge University Press, 1985.

- Shattered Nerves: Doctors, Patients and Depression in Victorian England. New York: Oxford University Press, 1991.

Oppenheimer, Melanie. All Work No Pay: Australian Civilian Volunteers in War. Walcha, NSW: Ohio Productions, 2002.

Owen, Alex. The Darkened Room: Women, Power, and Spiritualism in Late Nineteenth-Century England. London: Virago Press, 1989.

Parry, Gordon. N.M.A.: The Story of the First 100 Years. Dunedin: National Mortgage and Agency Company of New Zealand, 1964.

Payton, Philip. Regional Australia and the Great War: 'The Boys from Old Kio'. Exeter: University of Exeter Press, 2012. 
Phillips, Jock. A Man's Country?: The Image of the Pakeha Male, a History. Auckland: Penguin Books, 1987.

Phillips, Jock, Nicholas Boyack, and E. P. Malone, eds. The Great Adventure: New Zealand Soldiers Describe the First World War. Wellington: Allen \& Unwin/Port Nicholson Press, 1988.

Pickles, Katie. Female Imperialism and National Identity: Imperial Order Daughters of the Empire. Manchester: Manchester University Press, 2002.

Transnational Outrage: The Death and Commemoration of Edith Cavell. Basingstoke:

Palgrave Macmillan, 2007.

Platts, Una. Nineteenth Century New Zealand Artists: A Guide \& Handbook. Christchurch: Avon Fine Prints Limited, 1980.

Pool, Ian, Arunachalam Dharmalingam, and Janet Sceats. The New Zealand Family from 1840: A Demographic History. Auckland: Auckland University Press, 2007.

Porter, Frances. Born to New Zealand: A Biography of Jane Maria Atkinson. 1989. Reprint, Wellington: Bridget Williams Books, 1995.

Porter, Frances, and Charlotte Macdonald, eds. 'My Hand Will Write What My Heart Dictates': The Unsettled Lives of Women in Nineteenth-Century New Zealand as Revealed to Sisters, Family and Friends. Auckland: Auckland University Press, 1996.

Prochaska, F. K. Women and Philanthropy in $19^{\text {th }}$ Century England. Oxford: Clarendon Press, 1980.

Proctor, Tammy. Civilians in a World at War, 1914-1918. New York: New York University Press, 2010.

Pugsley, Christopher. Te Hokowbitu a Tu: The Maori Pioneer Battalion in the First World War. Auckland: Reed, 1995.

Rees, Peter. The Other Anzacs: Nurses at War, 1914-1918. Sydney: Allen \& Unwin, 2008.

Reiger, Kerreen. The Disenchantment of the Home: Modernizing the Australian family 18801940. Melbourne: Oxford University Press, 1985.

Reznick, Jeffrey. Healing the Nation: Soldiers and the Culture of Caregiving in Britain During the Great War. Manchester: Manchester University Press, 2004.

Robertson, Craig. The Passport in America: The History of a Document. Oxford: Oxford University Press, 2010.

Robinson, Howard. A History of the Post Office in New Zealand. Wellington: Government Printer, 1964. 
Rockel, Ian. Taking the Waters: Early Spas in New Zealand. Wellington: Government Printing Office Publishing, 1986.

Rogers, Anna. While You're Away: New Zealand Nurses at War 1899-1948. Auckland: Auckland University Press, 2003.

Rolleston, Rosamond. William \& Mary Rolleston: an Informal Biography. Wellington A. H. \& A. W. Reed, 1971.

Roper, Michael. The Secret Battle: Emotional Survival in the Great War. Manchester: Manchester University Press, 2009.

Rose, Phyllis. Parallel Lives: Five Victorian Marriages. London: Penguin, 1985.

Russell, Penny. A Wish of Distinction: Colonial Gentility and Femininity. Melbourne: Melbourne University Press, 1994.

Rutherdale, Robert. Hometown Horizons: Local Responses to Canada's Great War. Vancouver: UBC Press, 2004.

Sansom, Olga. The Stewart Islanders. Wellington: A.H. \& A. W. Reed, 1970.

Scott, Keith Douglas. Before Anzac, Beyond Armistice: The Central Otago Soldiers of World War One and the Home They left Behind. Auckland: Activity Press, 2009.

Scott Inglis, Andrea. Summer in the Hills: The Nineteenth-Century Moutain Resort in Australia. Melbourne: Australian Scholarly Publishing, 2007.

Seddon, T. E. Y. The Seddons: An Autobiography. Auckland: Collins, 1968.

Sinclair, Keith. A Destiny Apart: New Zealand's Search for National Identity. Wellington: Allen \& Unwin, 1986.

Smith, Bonnie, ed. Women's History in Global Perspective, Vol 1. Urbana: University of Illinois Press, 2004.

Smitley, Megan. The Feminine Public Sphere: Middle-Class Women and Civic Life in Scotland, c.1870-1914. Manchester: Manchester University Press, 2009.

Stanley, Peter. The Men of Mont St Quentin: Between Victory and Death. Melbourne: Scribe, 2009.

Steel, Frances. Oceania Under Steam: Sea Transport and the Cultures of Colonialism, c. 18701914. Manchester: Manchester University Press, 2011.

Stenhouse, John, ed. Christianity, Modernity and Culture: New Perspectives on New Zealand History. Adelaide: ATF Press, 2005. 
Stenhouse, John, and Jane Thomson, eds. Building God's Own Country: Historical Essays on Religions in New Zealand. Dunedin: Otago University Press, 2004.

Stoler, Ann Laura. Carnal Knowledge and Imperial Power: Race and the Intimate in Colonial Rule. Berkeley: University of California Press, 2002.

Strange, Julie-Marie. Death, Grief and Poverty in Britain, 1870-1914. Cambridge: Cambridge University Press, 2005.

Sutherland, Beth. My Dear Chick: A New Zealand Love Story, 1911-1948. Masterton: Fraser Books, 2008.

Tennant, Margaret. The Fabric of Welfare: Voluntary Organisations, Government and Welfare in New Zealand, 1840-2005. Wellington: Bridget Williams Books, 2007.

Paupers \& Providers: Charitable Aid in New Zealand. Wellington: Allen \& Unwin;

Historical Branch, Dept. of Internal Affairs, 1989.

Thom, Deborah. Nice Girls and Rude Girls: Women Workers in World War I. London: I.B. Tauris, 1998.

Thomson, Alistair. Anzac Memories: Living with the Legend. Melbourne: Oxford University Press, 1994.

Thomson, Jane, ed. Southern People: A Dictionary of Otago Southland Biography. Dunedin: Longacre Press, 1998.

Todman, Dan. The Great War: Myth and Memory. London: Hambledon Continuum, 2005.

Tolerton, Jane. An Awfully Big Adventure: New Zealand World War One Veterans Tell Their Stories. Auckland: Penguin Books, 2013.

- Ettie: a life of Ettie Rout. Auckland: Penguin, 1992.

Torpey, John. The Invention of the Passport: Surveillance, Citizenship and the State. Cambridge: Cambridge University Press, 2000.

Tosh, John. A Man's Place: Masculinity and the Middle-Class Home in Victorian England. Rev. ed. New Haven: Yale University Press, 1999.

- Manliness and Masculinities in Nineteenth-Century Britain. Harlow: Pearson Longman, 2005.

Tosh, John, and Michael Roper, eds. Manful Assertions: Masculinities in Britain Since 1900. London: Routledge, 1991.

Toynbee, Claire. Her Work and His: Family, Kin and Community in New Zealand 1900-1930. Wellington: Victoria University Press, 1995. 
Troughton, Geoffrey, ed. The Spirit of the Past: Essays on Christianity in New Zealand History. Wellington: Victoria University Press, 2011.

Vance, Norman. The Sinews of the Spirit: The Ideal of Christian Manliness in Victorian

Literature and Religious Thought. Cambridge: Cambridge University Press, 1985.

Wall, Richard, and Jay Winter. The Upheaval of War: Family, Work and Welfare in Europe, 1914-1918. Cambridge: Cambridge University Press, 1988.

Wanhalla, Angela. In/Visible Sight: The Mixed-Descent Families of Southern New Zealand. Wellington: Bridget Williams Books, 2009.

- Matters of the Heart: A History of Interracial Marriage in New Zealand. Auckland: Auckland University Press, 2013.

Watson, Janet. Fighting Different Wars: Experience, Memory, and the First World War in Britain. Cambridge: Cambridge University Press, 2004.

Wheeler, Michael. Death and the Future Life in Victorian Literature and Theology. Cambridge: Cambridge University Press, 1990.

Winter, Jay. Sites of Memory, Sites of Mourning: The Great War in European Cultural History. Cambridge, Cambridge University Press, 1995.

Winter, Jay, and Antoin Prost. The Great War in History: Debates and Controversies 1914 to the Present. Cambridge: Cambridge University Press, 2005.

Winter, Jay, and Jean-Louis Robert, eds. Capital Cities at War: Paris, London, Berlin 19141919. Cambridge: Cambridge University Press, 1997.

—., eds. Capital Cities at War: Paris, London, Berlin 1914-1919. Volume 2: A Cultural History. Cambridge: Cambridge University Press, 2007.

Winter, Jay, Geoffrey Parker, and Mary R. Habeck, eds. The Great War and the Twentieth Century. New Haven: Yale, 2000.

Woollacott, Angela. On Her Their Lives Depend: Munition Workers in the Great War. Berkeley: University of California Press, 1994.

—. To Try Her Fortune in London: Australian Women, Colonialism and Modernity. Oxford: Oxford University Press, 2001.

Young, Linda. Middle-Class Culture in the Nineteenth Century: America, Australia and Britain. Basingstoke: Palgrave Macmillan, 2003.

Ziino, Bart. A Distant Grief: Australians, War Graves and the Great War. Crawley: University of Western Australia Press, 2007. 


\section{ARTICLES}

Beaumont, Joan. 'Whatever Happened to Patriotic Women, 1914-1918?' Australian Historical Studies 115 (2000): 273-286.

Blum, Ann S. 'Bringing It Back Home: Perspectives on Gender and Family History in Modern Mexico.' History Compass 4/5 (2006): 906-926.

Bourke, Joanna. 'The Battle of the Limbs: amputation, artificial limbs and the Great War in Australia.' Australian Historical Studies 29, no. 110 (1998): 49-67.

Carr, Richard. 'Conservative veteran M.P.s and the "Lost Generation" Narrative after the First World War.' Historical Research 85, no. 228 (May 2012): 1-22.

Clarke, Alison. 'Churchgoing in New Zealand, 1874-1926: How “Mediocre” was it?' NZJH 42, no. 2 (2013): 106-135.

'Heavenly Visions: Otago Colonists' Concepts of the Afterlife.' Journal of Religious History 30, no. 1 (February 2006): 2-17.

Coontz, Stephanie. 'Historical Perspectives on Family Studies.' Journal of Marriage and the Family 62 (May 2000): 283-297.

Dalziel, Raewyn. 'The Colonial Helpmeet: Women's Role and the Vote in NineteenthCentury New Zealand.' NZJH 11, no. 2 (October 1977): 112-123.

Damousi, Joy. 'Private Loss, Public Mourning: Motherhood, Memory and Grief in Australia during the Inter-War Years.' Women's History Review 18, no. 2 (1999): 365-378.

Ditz, Toby. 'The New Men's History and the Peculiar Absence of Gendered Power: Some Remedies from Early American Gender History.' Gender \& History 16, no. 1 (April 2004): 1-35.

Doolittle, Megan. 'Close Relations? Bringing Together Gender and Family in English History.' Gender \& History 11, no. 3 (November 1999): 542-554.

Foley, Susan. "'I felt such a need to be loved...in a letter:" Reading the Correspondence of Leonie Leon and Leon Gambetta.' French History \& Civilization 1 (2005): 254-264.

Francis, Martin. 'The Domestication of the Male? Recent Research on Nineteenth- and Twentieth-Century British Masculinity.' The Historical Journal 45, no. 3 (September 2002): 637-652.

Gerber, David A. 'Acts of Deceiving and Withholding in Immigrant Letters: Personal Identity and Self-Presentation in Personal Correspondence.' Journal of Social History 39, no 2 (2005): 315-330 
Gibbons, Peter. 'The Far Side of the Search for Identity.' NZJH 37, no. 1 (2003): 38-49.

Gould, Ashley. 'From Taiaha to Ko: Repatriation and Land Settlement for Maori Soldiers in New Zealand after the First World War.' War \& Society 28, no. 2 (October 2009): 49-83.

Hamer, D. A. 'Towns in Nineteenth-Century New Zealand.' NZJH 13, no. 1 (1979): 524.

Hanna, Martha. “"A Republic of Letters”: The Epistolary Tradition in France during World War I.' American Historical Review 108, no. 5 (December 2003): 1338-1361.

Hart, F. Dudley. 'History of the Treatment of Rheumatoid Arthritis.' British Medical Journal 27 (March 1976): 763-765.

Hazelgrove, Jennifer. 'Spiritualism after the Great War.' Twentieth-Century British History 10, no. 4 (1999): 404-430.

Houlbrook, Matt. "“A Pin to see the Peepshow”: Culture, Fiction and Selfhood in Edith Thompson's letters, 1921-1922.' Past and Present, no. 207 (May 2010): 215-24.

Hucker, Graham. 'Defying Those Who Would Forget: A Hall of Remembrance and Its Narrative.' History Now 9, no.2 (2003): 10-13.

Hunter, Kate. 'More than an Archive of War: Intimacy and Manliness in the Letters of a Great War Soldier to the Woman He Loved, 1915-1919.' Gender \& History 25, no. 2 (August 2013): 339-354.

Hunter, Kathryn. 'Australian and New Zealand Fathers and Sons during the Great War: Expanding the Histories of Families at War'. First World War Studies 4, no. 2 (2013):185200 .

- "'Sleep on dear Ernie, your battles are o'er": A Glimpse of a Mourning Community, Invercargill, NZ, 1914-1925.' W ar in History 14, no. 1 (2007): 36-62.

Husbands, Paul. 'Poverty in Freeman's Bay 1886-1913.' NZJH 28, no. 1 (1994): 3-21.

Jalland, Pat. 'A Private and Secular Grief: Katharine Susannah Prichard Confronts Death and Bereavement.' History Australia 2, no 2 (2005): 42.1-42.15.

Koven, Seth. 'Prisoners of Their Beds: Invalids, Injured Soldiers, and Cultures of Convalescence in Nineteenth-Century and Early-Twentieth-Century Britain.' Radical History Review 94 (Winter 2006): 233-239.

—. 'Remembering and Dismemberment: Crippled Children, Wounded Soldiers, and the Great War in Great Britain.' The American Historical Review 99, no. 4 (October 1994): 1167-1202. 
Lake, Marilyn. 'Mission Impossible: How Men Gave Birth to the Australian Nation: Gender, Nationalism and other Seminal Acts.' Gender and History 4, no. 3 (1992): 305322.

Larsson, Marina. 'Restoring the Spirit: The Rehabilitation of Disabled Soldiers in Australia after the Great War.' Health and History 6, no. 2 (2004): 45-59.

Lyons, Martyn. 'Love Letters and Writing Practices: On Ecritures Intimes in the Nineteenth Century.' Journal of Family History 24 (1999): 232-239.

Mackinnon, Alison. 'Fantasizing the Family: Women, Families and the Quest for an Individual Self.' Women's History Review 15, no. 4 (September 2006): 663-675.

McCalman, Janet. Struggletown: Public and Private Life in Richmond, 1900-1965. Melbourne: Hyland House, 1998.

Moloughney, Brian, and John Stenhouse. "Drug-besotten, sin-begotten fiends of filth": New Zealanders and the Oriental Other, 1850-1920'. New Zealand Journal of History 33, no. 1 (1999): 43-64.

Montgomerie, Deborah. 'Reconnaissance: Twentieth-Century New Zealand War History at Century's Turn.' New Zealand Journal of History 37, no.1 (2003): 62-79.

Nelson, Elizabeth. 'Victims of War: The First World War, Returned Soldiers, and Understandings of Domestic Violence in Australia.' Journal of Women's History 19, no.4 (Winter 2007): 83-106.

O’Connor, P. S. 'The Awkward Ones - Dealing with Conscience, 1916-1918.' NZJH 8, no. 2 (1974): 118-137.

Parsons, Gwen. 'The New Zealand Home Front during World War One and World War Two.' History Compass 11, no.6 (2013): 419-428.

Peel, Mark. 'Charity, Casework and the Dramas of Class in Melbourne, 1920-1940: "Feeling Your Position."” History Australia 2, no. 3 (2005): 83.1-83.15.

Pickles, Katie. 'A Link in "The Great Chain of Empire Friendship": the Victoria League in New Zealand.' The Journal of Imperial and Commonwealth History 33, no. 1 (January 2005): 29-50.

Roper, Michael. 'Slipping Out of View: Subjectivity and Emotion in Gender History.' History Workshop Journal 59 (2005): 57-72.

Scates, Bruce. 'The Unknown Sock Knitter: Voluntary Work, Emotional Labour, Bereavement and the Great War.' Labour History 81 (Nov 2001): 29-49.

Stanley, Liz. 'The Epistolarium: On Theorizing Letters and Correspondences.' Auto/Biography 12 (2004): 201-235. 
—. 'The Epistolary Gift, the Editorial Third-Party, Counter-Epistolaria:

Rethinking the Epistolarium'. Life Writing 8, no. 2 (2011): 135-152.

Strange, Julie-Marie. "'She cried a very little”: Death, Grief and Mourning in WorkingClass Culture, c. 1880-1914.' Social History 27, no. 2 (May 2002): 143-161.

Tennant, Margaret. 'Fun and Fundraising: the Selling of Charity in New Zealand's Past.' Social History 38, no. 1 (2013): 45-65.

Teo, Hsu-Ming. 'Love Writes: Gender and Romantic Love in Australian Love Letters, 1860-1960.' Australian Feminist Studies 20, no. 48 (November 2005): 343-361.

Tilly, Louise. 'Women's History and Family History: Fruitful Collaboration or Missed Connection?' Journal of Family History 12, nos. 1-3 (1987): 303-315.

Walker, Franchesca. “'Descendants of a Warrior Race”: the Maori Contingent, New Zealand Pioneer Battalion, and Martial Race Myth, 1914-19.' War \& Society 31, no. 1 (March 2012): 1-21.

Ward, Paul. "Women of Britain Say Go": Women's Patriotism in the First World War.' Twentieth Century British History 12, no. 1 (2001): 23-45.

White, Richard. 'The Soldier as Tourist: The Australian Experience of the Great War.' War \& Society 5, no.1 (May 1987): 63-77.

Williams, Sarah. 'Victorian Religion: A Matter of Class or Culture?' Nineteenth Century Studies 17 (2003): 13-17.

Worthy, Scott. 'Communities of Remembrance: Making Auckland's War Memorial Museum.' Journal of Contemporary History 39 (2004): 599-618.

'A Debt of Honour: New Zealanders' First Anzac Days.' New Zealand Journal of History 36, no. 2 (2002): 185-200.

Ziino, Bart. 'A Kind of Round Trip: Australian Soldiers and the Tourist Analogy 191418.' War \& Society 25, no. 2 (2006): 39-52.

. "A Lasting Gift to His Descendants": Family Memory and the Great War in Australia'. History \& Memory 22, no. 2 (Fall/Winter 2010): 125-146.

\section{BOOK CHAPTERS}

Binney, Judith. “'In-Between” Lives: Studies from Within a Colonial Society.' In Disputed Histories: Imagining New Zealand's Pasts, edited by Tony Ballantyne and Brian Moloughney, 93-117; 250-254. Dunedin: Otago University Press, 2006. 
Brookes, Barbara, Annabel Cooper, and Robin Law. 'Situating Gender.' In Sites of Gender: Women, Men and Modernity in Southern Dunedin, 1890-1939, edited by Barbara Brookes, Annabel Cooper, and Robin Law, 1-14; 372-373. Auckland: Auckland University Press, 2003.

Byrnes, Giselle. 'Introduction: Reframing New Zealand History.' In The New Oxford History of New Zealand, edited by Giselle Byrnes, 1-18; 600-602. Melbourne: Oxford University Press, 2009.

Cannadine, David. 'War and Death, Grief and Mourning in Modern Britain.' In Mirrors of Mortality: Studies in the Social History of Death, edited by Joachim Whaley, 187-242. London: Europa Publications, 1981.

Clarke, Alison, "Tinged with Christian Sentiment": Popular Religion and the Otago Colonists, 1850-1900.' In Christianity, Modernity and Culture: New Perspectives on New Zealand History, edited by John Stenhouse, 126-127. Adelaide: ATF Press, 2005.

Clarke, Stephen. 'Return, Repatriation, Remembrance and the Returned Soldiers' Association 1916-22.' In New Zealand's Great War: New Zealand, the Allies \& the First World War, edited by John Crawford and Ian McGibbon, 157-180. Auckland: Exisle Publishing, 2007.

Cooper, Annabel, Erik Olssen, Kristen Thomlinson, and Robin Law. 'The Landscape of Gender Politics: Place, People and Two Mobilisations.' In Sites of Gender, edited by Brookes, Cooper, and Law, 15-49; 373-376.

Davidoff, Leonore. 'The Family in Britain.' In The Cambridge Social History of Britain, 1750-1950, Volume 2: People and their Environment, edited by F. M. L. Thompson, 71-130. Cambridge: Cambridge University Press, 1990. http://universitypublishingonline.org/ cambridge/histories/ebook.jsf?bid=CBO9781139055598, accessed 22 March 2014.

Davidson, Allan. 'New Zealand Churches and Death in the First World War.' In New Zealand's Great War, edited by Crawford and McGibbon, 447-466.

Fell, Alison S. 'Nursing the Other: the Representation of Colonial Troops in French and British First World War Nursing Memoirs.' In Race, Empire and First World War Writing, edited by Santanu Das, 158-174. Cambridge: Cambridge University Press, 2011.

Garton, Stephen. 'Return home: War, Masculinity and Repatriation.' In Gender and War: Australians at War in the Twentieth Century, edited by Joy Damousi and Marilyn Lake, 191204. Cambridge: Cambridge University Press, 1995.

Grayzel, Susan. 'Across Battle Fronts: Gender and the Comparative History of Modern European War'. In Comparison in History: Europe in Cross-National Perspective, edited by Deborah Cohen and Maura O’Connor, 71-84. London: Routledge, 2004. 
Grimshaw, Patricia. 'Marriage and Families.' In Australians 1888, edited by Graeme Davison, J. W. McCarty, and Ailsa McLeary, 296-322. Sydney: Fairfax, Syme \& Weldon Associates, 1987.

Hareven, Tamara K. 'Family History at the Crossroads.' In Family History at the Crossroads: A Journal of Family History Reader, edited by Tamara Hareven and Andrejs Plakans, vii-xxi. Princeton: Princeton University Press, 1987.

Heenan, Brian and Sara Johnsen. 'To and From, There and Back: Gender in Spacial Mobility.' In Sites of Gender, edited by Brookes, Cooper, and Law, 226-257.

Howarth, Janet. “'In Oxford but ... not of Oxford”: The Women's Colleges.' In History of the University of Oxford, Volume VII, Nineteenth-Century Oxford, Part 2, edited by M. G. Brock and M.C. Curthoys, 237-307. Oxford: Oxford University Press, 2000.

Hutching, Megan. 'The Moloch of War: New Zealand Women Who Opposed the War.' In New Zealand's Great War, edited by Crawford and McGibbon, 85-95.

Keenan, Ria. 'On the Triangle Trail: The New Zealand YMCA and the Great War.' In New Zealand's Great War, edited by Crawford and McGibbon, 354-363; 622-623.

Lineham, Peter. 'First World War Religion'. In New Zealand's Great War, edited by Crawford and McGibbon, 467-492.

Luckins, Tanja. "Crazed with Grief?”: The Asylum and the Great War in Australia.' In 'Madness' in Australia: Histories, Heritage and the Asylum, edited by Catharine Coleborne and Dolly MacKinnon, 169-179. St Lucia, Queensland: University of Queensland Press, 2003.

Macdonald, Charlotte. 'Too Many Men and Too Few Women: Gender's "Fatal Impact" in Nineteenth-Century Colonies.' In The Gendered Kiwi, edited by Caroline Daley and Deborah Montgomerie, 17-35. Auckland: Auckland University Press, 1999.

Magri, Susanna. 'Housing.' In Capital Cities at War: Paris, London, Berlin, 1914-1919, rev. ed., edited by Jay Winter and Jean-Louis Robert, 374-417. Cambridge: Cambridge University Press, 1999.

Nolan, Melanie. 'Keeping New Zealand's Home Fires Burning: Gender, Welfare and the First World War.' In New Zealand's Great War, edited by Crawford and McGibbon, 493-515.

Olssen, Erik. 'Families and the Gendering of European New Zealand in the Colonial Period, 1840-80.' In The Gendered Kiwi, edited by Daley and Montgomerie, 37-62.

'Towards a New Society.' In The Oxford History of New Zealand, edited by W. H. Oliver, 250-278; 534-538. Wellington: Oxford University Press, 1981. 
'Working Gender, Gendering Work: Occupational Change and Continuity in Southern Dunedin.' In Sites of Gender, edited by Brookes, Cooper, and Law, 50-90; 376385.

Olssen, Erik, and Andree Levesque. 'Towards a History of the European Family in New Zealand.' In Families in New Zealand Society, edited by Peggy G. Kooman-Boyden, 1-25. Wellington: Methuen Publications, 1978.

Page, Dorothy. 'Women and Nationality: Feminist Organisations in the Inter-War Period.' In Women in History, edited by Brookes, Macdonald, and Margaret Tennant, 156-195.

Parsons, Gwen. 'Debating the War: The Discourses of War in the Christchurch Community.' In New Zealand's Great War, edited by Crawford and McGibbon, 550-568

Roche, Michael. 'Empire, Duty and Land.' In (Dis)Placing Empire - Renegotiating British Colonial Geographies, edited by Lindsay Proudfood and Michael Roche, 135-153, Aldershot, Hampshire: Ashgate, 2005.

Reznick, Jeffrey. 'Work-Therapy and the Disabled British Soldier in Great Britain in the First World War: The Case of Shepherd's Bush Military Hospital, London.' In Disabled Veterans in History, edited by David Gerber, 185-203. Ann Arbor: University of Michigan Press, 2000.

Rollet, Catherine. 'The Home and Family Life.' In Capital Cities at War. Volume 2: A Cultural History, edited by Jay Winter and Jean-Louis Robert, 315-353. Cambridge: Cambridge University Press, 2007.

Rotundo, E. Anthony. 'Learning about Manhood: Gender Ideals and the Middle-Class Family in Nineteenth-Century America.' In Manliness and Morality: Middle-Class Masculinity in Britain and America, 1800-1940, edited by J. A. Mangan and James Walvin, 35-51. New York: St Martin's Press, 1987.

Ross, John. 'Book Buyers and Collectors.' In Book \& Print in New Zealand: A Guide to Print Culture in Aotearoa, edited by Penny Griffith, Ross Harvey, and Keith Maslen, 197212. Wellington: Victoria University Press, 1997, http: //nzetc.victoria.ac.nz/tm/ scholarly/tei-GriBook.html, accessed 18 February 2014.

Smart, Judith. 'Feminists, Food and the Fair Price: The Cost-of-Living Demonstrations in Melbourne, August-September 1917.' In Gender and War: Australians at War in the Twentieth Century, edited by Joy Damousi and Marilyn Lake, 274-301. Cambridge: Cambridge University Press, 1995.

Soutar, Monty. 'Te Hokowhitu-A-Tu: A Coming of Age.' In New Zealand's Great War, edited by Crawford and McGibbon, 96-105. 
Tennant, Margaret. 'The Decay of Home Life?: The Home in Early Welfare

Discourses.' In At Home in New Zealand: Houses, History, People, edited by Barbara Brookes, 24-40; 228-229. Wellington: Bridget Williams Books, 2000.

Torpey, John. 'The Great War and the Birth of the Modern Passport System.' In Documenting Individual Identity: The Development of State Practices in the Modern World, edited by Jane Caplan and John Torpey, 256-270. Princeton: Princeton University Press, 2001.

Wanhalla, Angela. 'Family, Community and Gender.' In The New Oxford History of New Zealand, edited by Giselle Byrnes, 447-464; 691-697.

Woollacott, Angela. 'Sisters and Brothers in Arms: Family, Class, and Gendering in World War I Britain.' In Gendering War Talk, edited by Miriam Cooke and Angela Woollacott, 128-147. Princeton: Princeton University Press, 1993.

Winter, Jay. 'The European Family and the Two World Wars.' In The History of the European Family, Volume 3: Family Life in the Twentieth Century, edited by David I. Kertzer and Marzio Barbagli, 152-173. New Haven: Yale University Press, 2003.

\section{ELECTRONIC RESOURCES}

Bell, Beatrice Enid. War Diary 5 April - 6 May 1917. MSDL-0674. ATL. In First World War Experiences Database, accessed 15 November 2013.

Bowerbank, Major. 'New Zealand Hospitals in Egypt.' In The War Effort of New Zealand. Auckland: Whitcombe \& Tombs, 1923. In 'New Zealand in the First World War 19141918.' NZETC, http:// nzetc.victoria.ac.nz/tm/scholarly/tei-WH1-Effo.html, accessed 29 July 2013.

Breward, Ian. 'Waddell, Rutherford.' DNZB, updated 30-Oct-2012, http://www.TeAra.govt.nz/en/biographies/2w1/waddell-rutherford, accessed 18 March 2013.

Brooking, Tom. 'Mackenzie, Thomas Noble.' DNZB, updated 30-Oct-2012, DNZB, http://www.TeAra.govt.nz/en/biographies/3m18/mackenzie-thomas-noble, accessed 5 August 2013.

'Building Archerfield?,' Hocken Snapshop, http://hockensnapshop.ac.nz/nodes/view/ 8178 (Hocken Library Snapshop), accessed 4 October 2013.

'Cabinet Ministers of 1932.' PAColl-5469-041. ATL, http://natlib.govt.nz/records/ 22898447, accessed 29 March 2014.

Clayton, Garry. 'Davies, Richard Hutton.' DNZB, updated 30-Oct-2012, http://www.TeAra.govt.nz/en/biographies/3d3/davies-richard-hutton, accessed 23 March 2014. 
Cowan, James. 'Famous New Zealanders - No. 20 - Sir Douglas Maclean - Settler and Nation-Builder.' In The New Zealand Railways Magazine. 9, no. 8 (November 1, 1934), NZETC, http://nzetc.victoria.ac.nz/tm/scholarly/tei-Gov09_08Rail-t1-body-d7.html, accessed 22 April 2013.

Dale, Stephanie. 'Stewart, William Downie.' DNZB, updated 30-Oct-2012, http://www.TeAra.govt.nz/en/biographies/3s35/stewart-william-downie, accessed 23 March 2014.

Darley, Gillian. 'Hill, Octavia (1838-1912).' ODNB, updated May-12, http://www.oxforddnb.com/view/article/33873, accessed 31 January 2014.

Gardner, W. 'Rolleston, William.' DNZB, updated 30-Oct-2012. http://www.TeAra.govt.nz/en/biographies/1r17/rolleston-william, accessed 23 March 2014.

'Government Baths, Rotorua, 1900. PAColl-734479. ATL. http://natlib.govt.nz/ records/22321136, accessed 29 March 2014.

Hansen, Penelope, 'Mackenzie, Clutha Nantes.' DNZB, updated 12-Nov-2013, http://www.TeAra.govt.nz/en/biographies/4m17/mackenzie-clutha-nantes, accessed 13 March 2014.

Hodgkin, Thomas. 'Fry, Sara Margery (1874-1958).' Revised by Mark Pottle, ODNB, updated May-07, http://www.oxforddnb.com/view/ article/33286, accessed 29 January 2014.

McAloon, Jim. 'Ritchie, John Macfarlane.' DNZB, updated 15-Jan-2014, http://www.TeAra.govt.nz/en/biographies/2r24/ritchie-john-macfarlane, accessed 23 March 2014.

McGibbon, Ian. 'Something of Them is Here Recorded': Official History in New Zealand. Westport: Praeger, 2003. In NZETC, http://nzetc.victoria.ac.nz / tm/scholarly/teiMcGSome.html, accessed 24 March 2014.

Ministry for Culture and Heritage. '1915 - Canterbury.' http:/ /www.nzhistory.net.nz /war/canterbury-mounted-rifles/1915, accessed 17 February 2014.

Ministry for Culture and Heritage. 'Tapanui Lodge Roll of Honour.' http:www.nzhistory.net/media/photo/tapanui-lodge-roll-honour-board, accessed 12 December 2011.

Myers, Lt. Col. 'New Zealand Hospitals in the United Kingdom.' In The W ar Effort of New Zealand, Auckland: Whitcombe \& Tombs, 1923. NZETC, http://nzetc.victoria.ac.nz/tm/scholarly/tei-WH1-Effo-t1-body-d6-d3.html, accessed 9 April 2013. 
Nolan, Melanie, 'Runciman, Jane Elizabeth.' DNZB, updated 30-Oct-2012, http://www.TeAra.govt.nz/en/biographies/3r33/runciman-jane-elizabeth, accessed 26 March 2014.

Page, Dorothy. 'Freeman, Caroline - Biography.' DNZB, updated 30-Oct-12, http://www.TeAra.govt.nz/en/biographies/2f26/freeman-caroline, accessed 17 February 2014.

Parry, Gordon. 'Cumming, Francis George.' DNZB, updated 30-Oct-2012, http://www.TeAra.govt.nz/en/biographies/3c43/cumming-francis-george, accessed 26 March 2014.

Pedersen, Susan. 'Rathbone, Eleanor Florence (1872-1946).' ODNB, updated Jan-11, http://www.oxforddnb.com/view/article/35678, accessed 29 January 2014.

Starky, Suzanne. 'Rolleston, Elizabeth Mary.' DNZB, updated 30-Oct-2012, http://www.TeAra.govt.nz/en/biographies/1r16/rolleston-elizabeth-mary, accessed 26 March 2014.

'Stewart Family.' Hocken Snapshop, http://hockensnapshop.ac.nz/nodes/view/32595 (Hocken Library, Dunedin), accessed 3 March 2014.

Stone, R. C. J. 'Myers, Arthur Mielziner.' DNZB, updated 30-Oct-2012, http://www.TeAra.govt.nz/en/biographies/3m66/myers-arthur-mielziner, accessed 26 March 2014.

Wilkie, Yvonne, 'Stewart, Mary Downie.' DNZB, updated 26-Feb-2014, http://www.TeAra.govt.nz/en/biographies/3s34/stewart-mary-downie, accessed 29 March 2014.

'William Downie Stewart, London, England.' PAColl-7081-59. ATL. http:// natlib.govt.nz/records/22326843, accessed 29 March 2014.

'William and Mary Downie Stewart.' PA-Coll-6301-31. ATL. http://natlib.govt.nz/ records/ 22341700 , accessed 29 March 2014.

\section{THESES}

Barnes, Felicity. 'New Zealand's London: the Metropolis and New Zealand Culture, 1890-1940.' PhD thesis, University of Auckland, 2008.

Bennett, Charlotte Jayne Silvia. "'Now That the War is Over, We Have Something Else to Worry Us": New Zealand Children's Responses to Crises, 1914-1918.' MA thesis, Victoria University of Wellington, 2012.

Boston, Peter. "The Bacillus of Work": Masculinity and the Rehabilitation of Disabled Soldiers in Dunedin, 1919-1939.' BA Honours thesis, University of Otago, 1993. 
Broadley, Shaun D. 'Spirited Visions: A Study of Spiritualism in New Zealand Settler Society, 1870-1890.' PhD thesis, University of Otago, 2000.

Brown, Hayley. 'Loosening the Marriage Bond: Divorce in New Zealand, c. 1890s - c. 1950s.' PhD thesis, Victoria University of Wellington, 2011.

Clarkson, Coralie. 'The Reality of Return: Exploring the Experiences of World War One Soldiers after their Return to New Zealand.' MA thesis, Victoria University of Wellington, 2011.

Dale, Stephanie M. 'Gentleman of Politics: A life of William Downie Stewart 1878 1949.’ MA thesis, University of Otago, 1981.

Francis, Andrew. “'To be Truly British We Must Be Anti-German”: Patriotism, Citizenship and Anti-Alienism in New Zealand during the Great War.' PhD thesis, Victoria University of Wellington, 2009.

Frank, Timothy. “About Our Father's Business”: Fatherhood in New Zealand 19001940.' PhD thesis, University of Auckland, 2004.

Gould, Ashley. 'Proof of Gratitude? Soldier Land Settlement in New Zealand after World War I.' PhD thesis, Massey University, 1992.

Hucker, Graham. 'The Rural Home Front: A New Zealand Region and the Great War 1914-1926.' PhD thesis, Massey University, 2006.

Labrum, Bronwyn. 'Family Needs and Family Desires: Discretionary State Welfare in New Zealand, 1920-1970.' PhD thesis, Victoria University of Wellington, 2000.

Liebich, Susann. 'Connected Readers: Reading Practices and Communities Across the British Empire, c. 1890-1930'. PhD thesis, Victoria University of Wellington, 2011.

Littlewood, David. “'Should He Serve?” The Military Service Boards' Operations in the Wellington Provincial District, 1916-1918.' MA thesis, Massey University, 2010.

Loveridge, Steven. “'Sentimental Equipment”: New Zealand, the Great War and Cultural Mobilisation.' PhD Thesis, Victoria University of Wellington, 2013.

Luxford, Sarah. 'Passengers for the War? The Involvement of New Zealand Women in Employment during the Great War 1914-1918.’ MA thesis, Massey University, 2005.

McLeod, J. C. 'Activities of New Zealand Women During World War One.' BA Honours thesis, University of Otago, 1978.

Millar, Grace. 'Families and the 1951 Waterfront Lockout.' PhD Thesis, Victoria University of Wellington, 2013. 
Piesse, Sarah Jane. 'Patriotic Welfare in Otago: A History of the Otago Patriotic and General Welfare Association 1914-1950 and the Otago Provincial Patriotic Council 1939.' MA thesis, University of Otago, 1981.

Plumridge, E. W. 'Labour in Christchurch: Community and Consciousness, 1914 1919.' MA thesis, University of Canterbury, 1979.

Robertson, Yvonne Margaret. 'A Victorian Lady in an Age of Change: the life of Mary Downie Stewart 1876 - 1957.' PG Diploma in Arts thesis, University of Otago, 1990.

Rodgers, Jan A. “"A Paradox of Power and Marginality”: New Zealand Nurses” Professional Campaign during War, 1900-1920.’ PhD thesis, Massey University, 1994.

Walker, Elizabeth. “'The Living Death”: The Repatriation Experience of New Zealand's Disabled Great War Servicemen.’ MA thesis, Victoria University of Wellington, 2013.

Woods, Megan C. 'Re/producing the Nation: Women Making Identity in New Zealand, 1906-1925.' MA thesis, University of Canterbury, 1997.

\section{CONFERENCE PAPERS}

Clarke, Alison. 'Rachel Stewart's Photograph and the Tragedies of Victorian Motherhood.' Paper presented at the New Zealand Historical Association Conference, Dunedin, November 2013.

Russell, Penny. 'Distance Lends Enchantment.' Keynote speech, Women’s History Network, Australian Historical Association Conference, Adelaide, July 2012. 